\title{
Implied Licences
}

in

Copyright Law

Poorna Mysoor

DPhil Thesis

Faculty of Law

University of Oxford 


\begin{abstract}
Copyright licences can be implied when the doing of a restricted act is covered neither by the express licence of the copyright owner, nor by one of the statutory limitations and exceptions. The manner in which copyright licences are implied, therefore, holds the key to broadening the scope of permissible acts. In contrast to the rigidity of statutory limitations and exceptions, implied licences are more malleable in being able to respond to a diverse set of circumstances, as the need arises. Thus, implied licences can serve as a flexible and targeted mechanism to balance competing interests, including those of copyright owners and content users, especially in today's dynamic technological environment. However, implication as a process is contentious, and there are no established rules for implying a licence. Implication of a copyright licence is even more complicated because the conceptualisation of a copyright licence is unsatisfactory. The resulting uncertainty has prevented implied licences from being embraced more readily by the courts. The objective of this thesis is, therefore, firstly, to reconceptualise a copyright licence that is broad enough to accommodate the diverse circumstances in which copyright licences arise, and certain enough to assist in finding their constituents; secondly, to propose frameworks for implying copyright licences in a methodical and transparent manner, based on three sources: the consent of the copyright owner; an established custom; and state intervention to achieve public policy goals. The frameworks are also customised differently for implied bare and implied contractual licences. The thesis demonstrates the robustness of these frameworks by rationalising them with the existing case law. Underscoring the contemporary relevance of implied licences, in conclusion, the thesis tests and validates the frameworks in relation to three essential and ubiquitous functions on the internet - browsing, hyperlinking and indexing.
\end{abstract}




\section{Acknowledgments}

I am deeply grateful to my supervisor, Professor Graeme Dinwoodie. Without his meticulous review and insightful comments on countless drafts, this work would not have reached its fruition.

I am grateful to the valuable comments I received from my internal examiners, Dr Dev Gangjee and Ms Sarah Green, both at my Transfer of Status and Confirmation of Status, and my external examiner, Professor Robert Burrell, Head of School, University of Sheffield School of Law. Many thanks are also due to Dr Emily Hudson, Senior Lecturer, King's College, London, for her diligent supervision during the first year of my DPhil.

Through the course of my DPhil, I was fortunate to have discussions with some of the leading experts in their respective fields, which not only enriched my research experience, but added a valuable dimension to my thesis. Chief among them are Professor Severine Dusollier, University of Nemur, Professor Ansgar Ohly, University of Munich, Professor Simon Gardner, Lincoln College, Oxford, Professor Joshua Getzler, St Hugh's College, Oxford and Dr Simon Douglas, Jesus College, Oxford.

Specific aspects of my research were enriched by specific persons, without whose timely and expert assistance, my research would have been incomplete. I am deeply grateful to Professor Andrew Halpin, National University of Singapore, for his assistance with Hohfeldian analysis. My knowledge of the internet and the specifics of the internet crawling technologies is all thanks to my dear friend, Pascal Kesseli, DPhil Candidate, Department of Computer Science, Oxford. I also relied on other DPhil students at the Law Faculty at Oxford for their specialist knowledge in their respective areas, for which I am deeply grateful: Ana Bobic and Menelaos Markakis for EU law and Kaplana Sivabala for public law. The camaraderie and emotional support I received from Myrna Martin, Daniela Simone, Andrea Dolcetti, Menelaos Markakis, Tonya Muller, Ana Bobic, Karen Walsh, Thomas Dysart, Alvaro Fernandes and many more friends, made all the difference to my DPhil research, which would otherwise have been a dauntingly solitary experience.

I am also deeply grateful to the constant and unwavering support lent by Ms Ruth Bird, the former librarian of the Bodleian Law Library, and her entire team, especially through some of the most significant renovations the library has ever seen.

I am also thankful to Professor Maurizio Borghi, the director of the Centre for Intellectual Property Policy and Management, Bournemouth University for his invitation to present my thesis for the first time before an audience. The comments I received from Professor Borghi and his colleagues further enriched my thesis.

Lastly, but most importantly, I cannot thank my parents enough for always believing in me, and Anup for his unflinching support and inspiration. 


\section{Table of Contents}

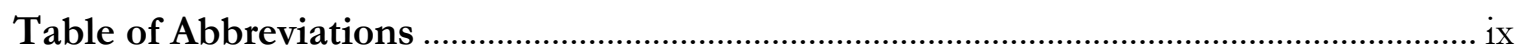

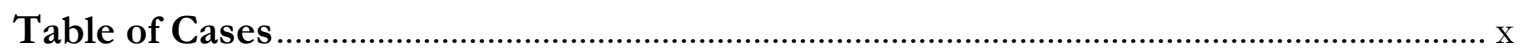

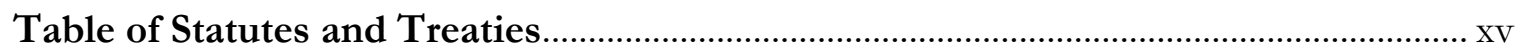

List of Tables and Charts................................................................................................. xix

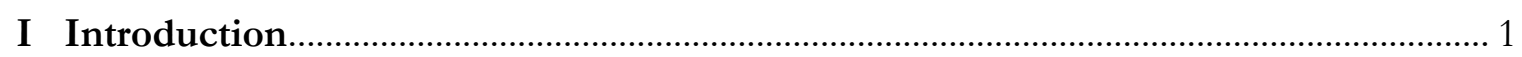

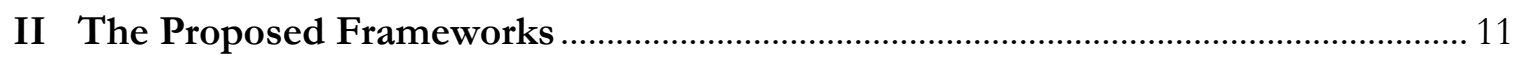

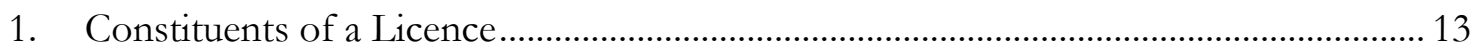

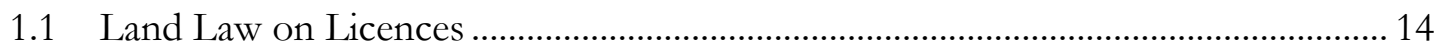

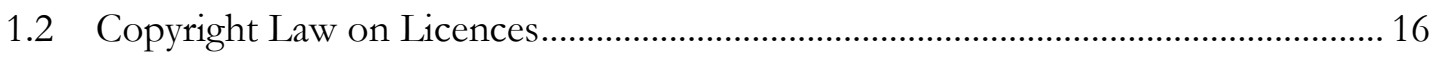

1.3 Analytical Jurisprudence on Licences ......................................................................... 20

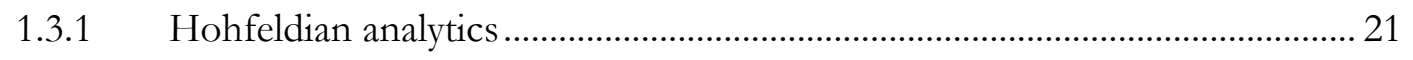

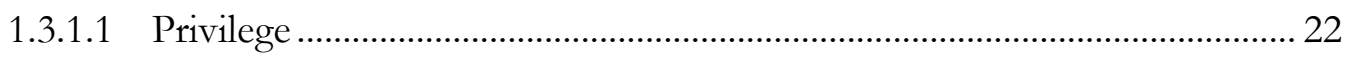

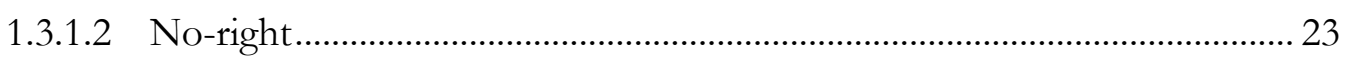

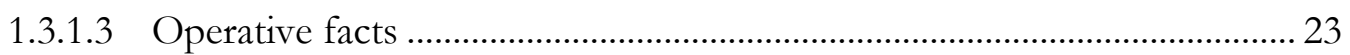

1.3.2 Benefits of Hohfeldian conception ...................................................................... 24

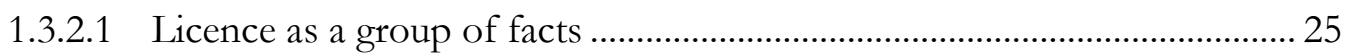

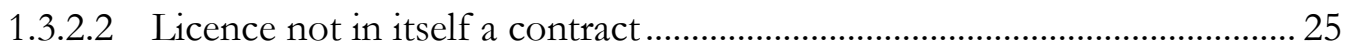

1.3.2.3 Licence as a legal relationship and bare licences ........................................ 26

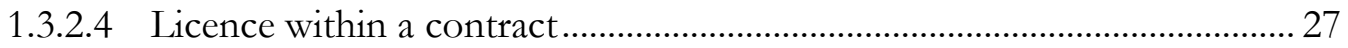

1.3.3 Limitations of Hohfeldian conception ............................................................. 29

2. Copyright Law and Express Copyright Licences ………………………......................... 30

2.1 Sources of Power.......................................................................................................... 30

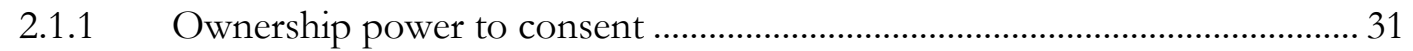

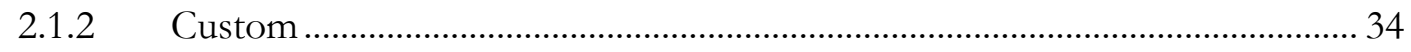

2.1.3 State intervention for public policy reasons ......................................................... 36

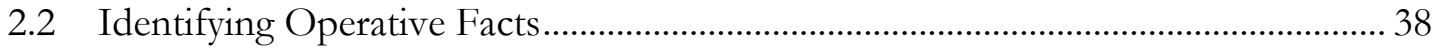

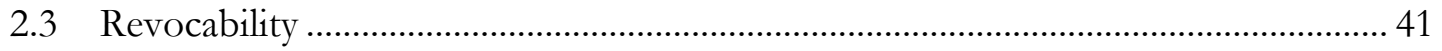

2.3.1 Revocability under different sources of power .................................................. 41

2.3.2 Other FLCs contributing to revocability............................................................ 43

3. Frameworks for Implying Copyright Licences .................................................................. 44

3.1 Consent of the Copyright Owner ................................................................................ 47

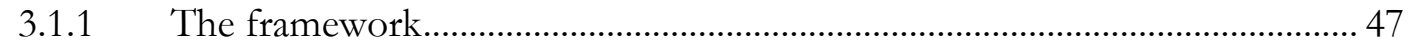

3.1.1.1 Positive act ..................................................................................................... 49

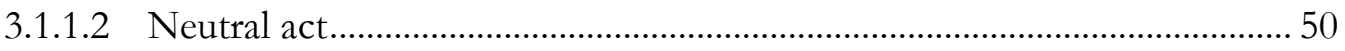


3.1.1.3 Knowledge of the copyright owner........................................................... 52

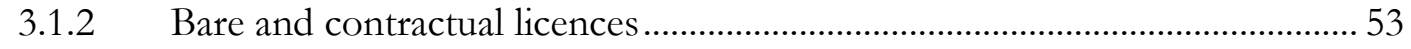

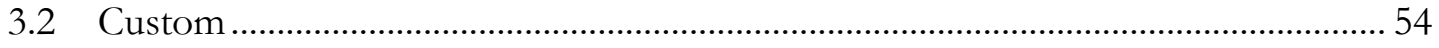

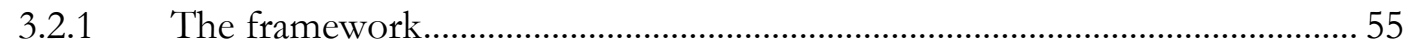

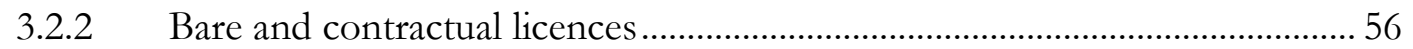

3.3 State Intervention to Achieve a Policy Goal ............................................................... 56

3.3.1 Policy-based implied licences vis-à-vis L\&Es and compulsory licences ...... 57

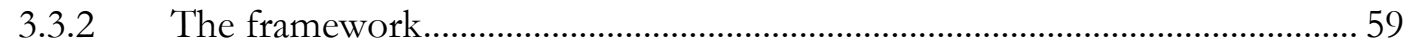

3.3.2.1 Policy-based implied contractual licences ..................................................... 59

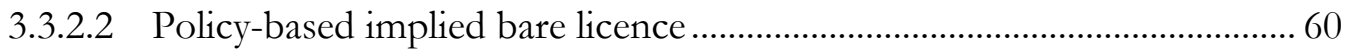

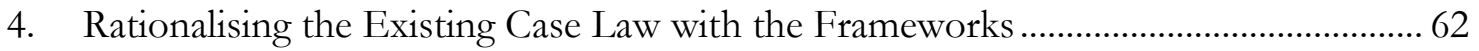

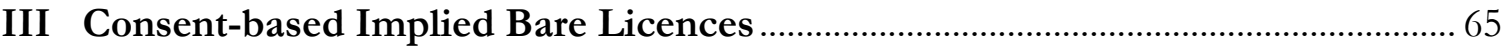

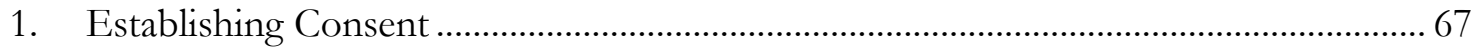

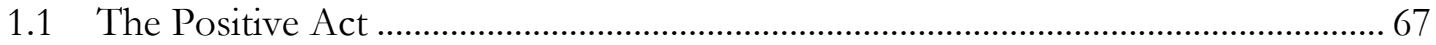

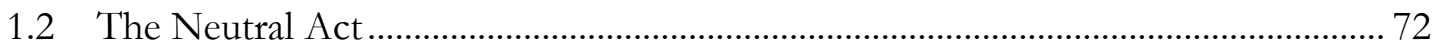

1.3 The knowledge of the copyright owner ..................................................................... 74

1.3.1 Realisation of authorship of the work ……..................................................... 75

1.3.1.1 Authorship and joint authorship ................................................................. 75

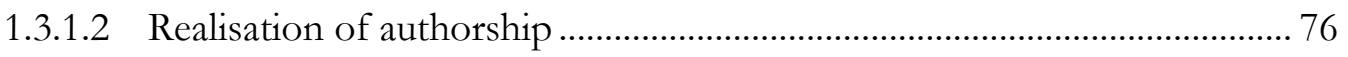

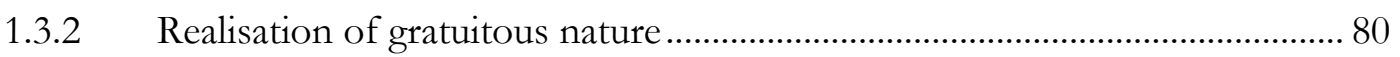

1.3.2.1 Being paid as a performer as opposed to a joint-author ............................ 84

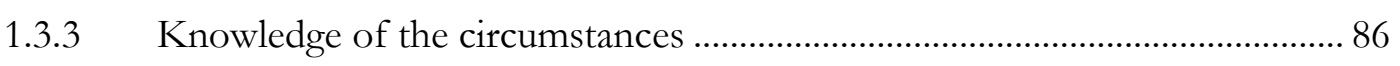

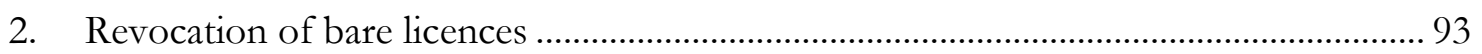

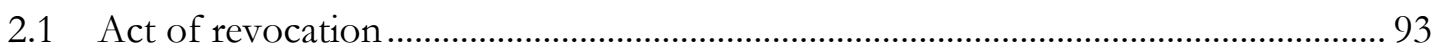

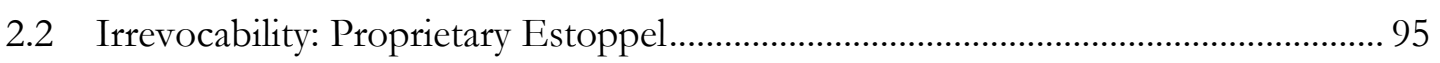

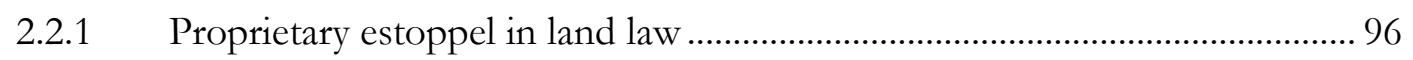

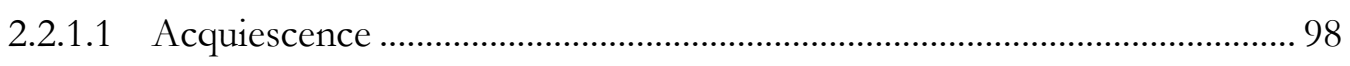

2.2.1.2 Representation and the role of unconscionability.................................... 100

2.2.1.3 Promise/Assurance …………………………................................................. 103

2.2.2 Proprietary estoppel in copyright cases .............................................................. 104

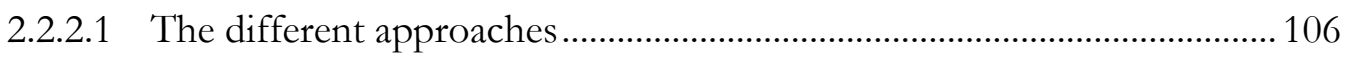

2.2.2.2 Remedy to enforce proprietary estoppel ................................................ 114

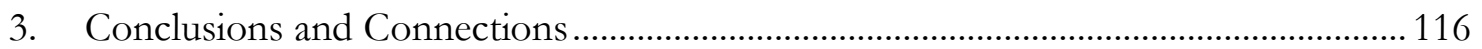

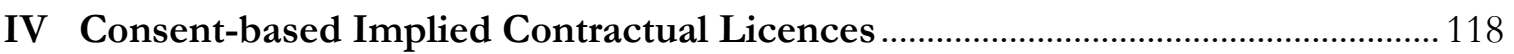

1. Principles of Implying a Term into a Contract ................................................................ 122 
1.1 Tests to Imply a Term in Fact

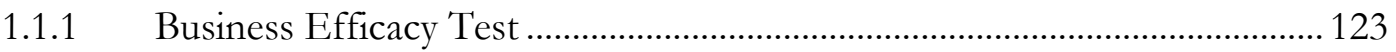

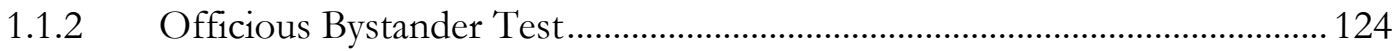

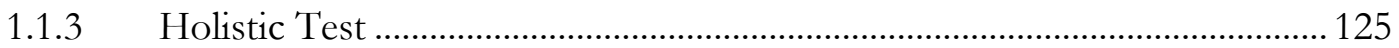

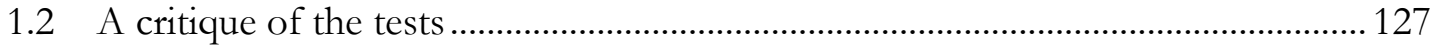

2. Implied Contractual Licence within the Copyright Context.........................................128

2.1 Commissioning Contracts …………………............................................................ 129

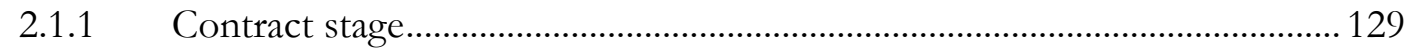

2.1.1.1 Principles in Robin Ray v Classic FM...................................................... 131

2.1.1.2 How Ray has been applied ........................................................................ 134

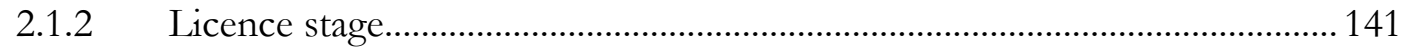

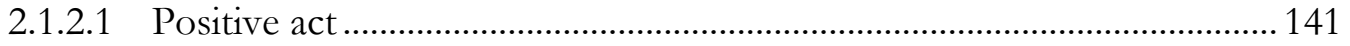

2.1.2.2 Neutral act.................................................................................................. 142

2.1.2.3 Knowledge of the copyright owner............................................................... 143

2.2 Copyright Exploitation Contracts .............................................................................. 158

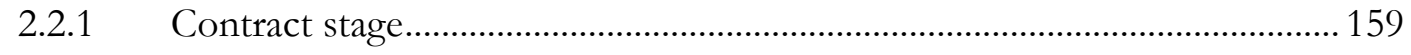

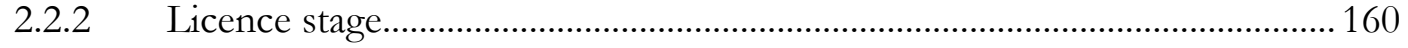

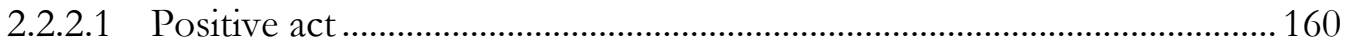

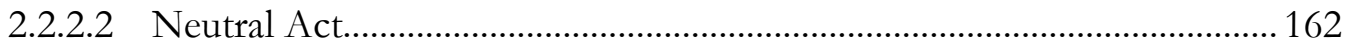

2.2.2.3 Knowledge of the copyright owner............................................................. 165

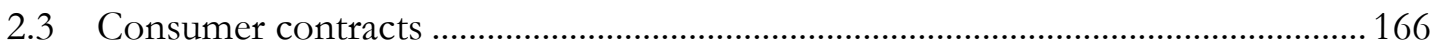

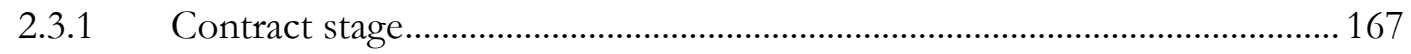

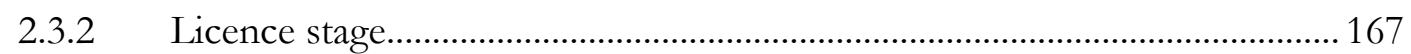

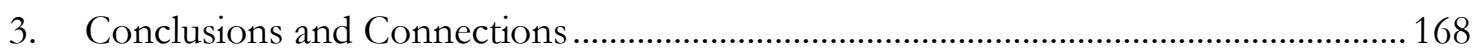

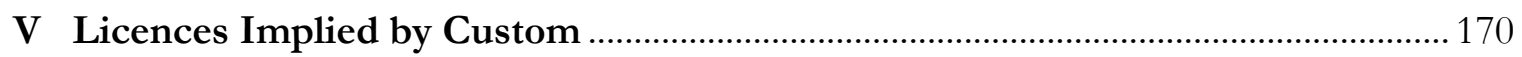

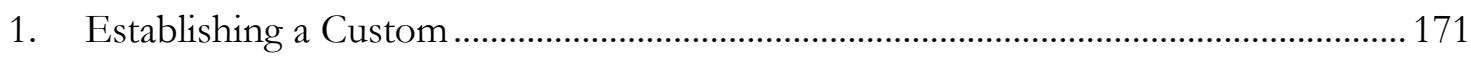

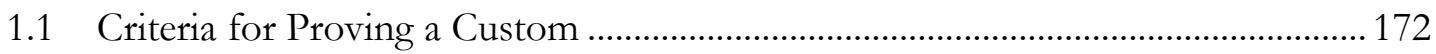

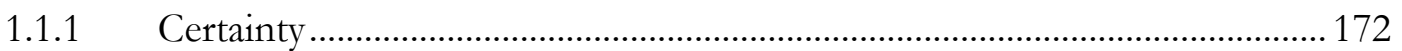

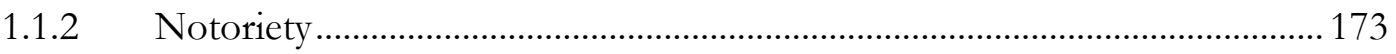

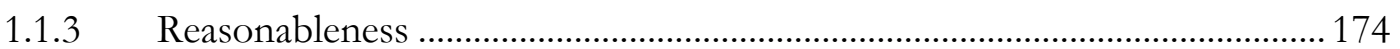

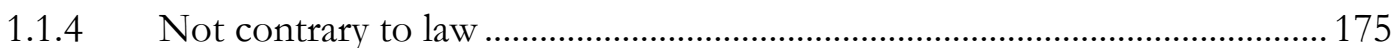

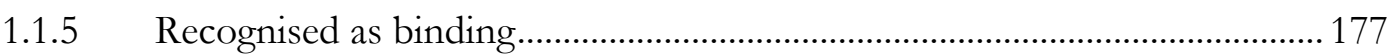

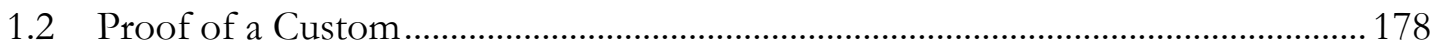

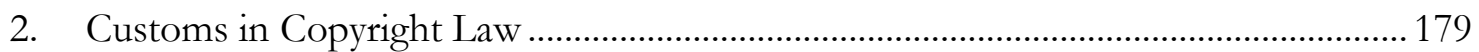

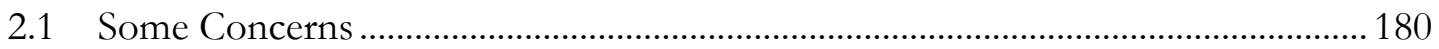




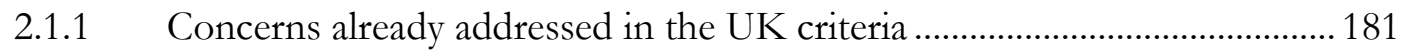

2.1.2 Concerns requiring refinement of the UK criteria ......................................... 182

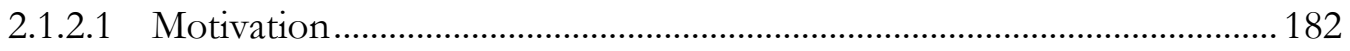

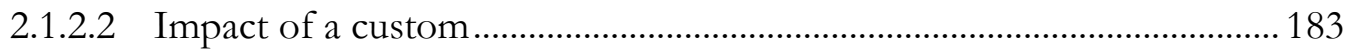

2.1.2.3 Representative nature ........................................................................... 184

2.2 Custom as a Basis for Implying a Copyright Licence ............................................... 184

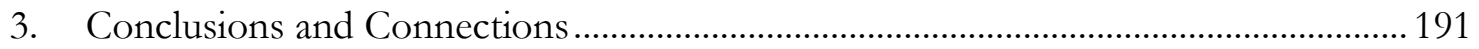

VI Policy-based Implied Contractual Licences …………………………........................ 193

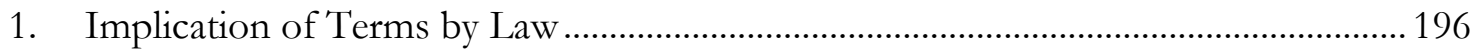

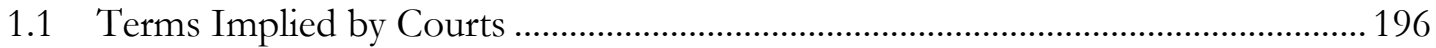

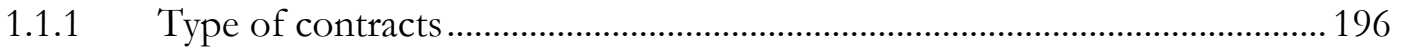

1.1.2 Test of necessity or reasonableness? ................................................................... 197

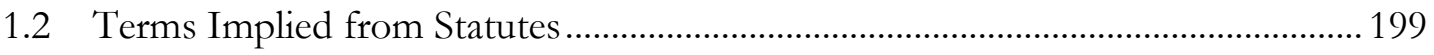

2. Policy-based Implied Contractual Licences in Copyright Context ...............................2200

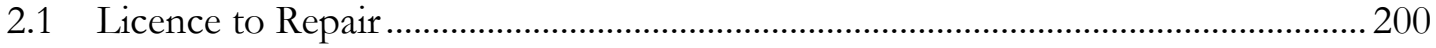

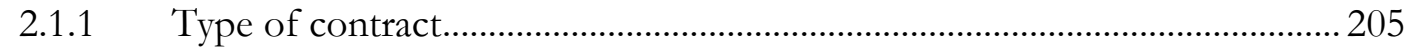

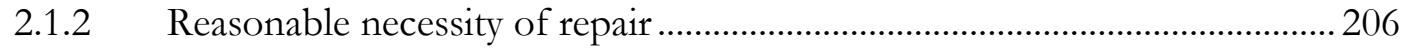

2.1.3 Statutory provisions embodying repair......................................................... 207

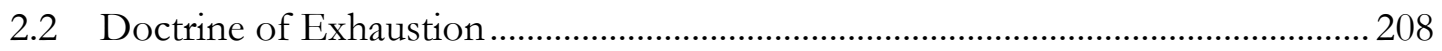

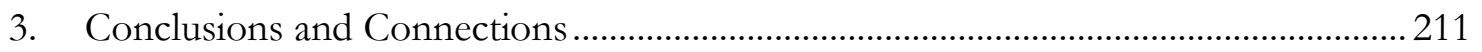

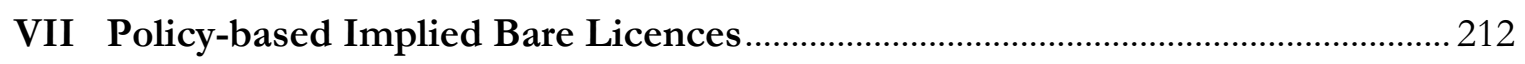

1. Section 171(3), CDPA and the Common Law Rule ...................................................... 213

1.1 Historical Context of Section 171(3) and Courts' Power ........................................... 214

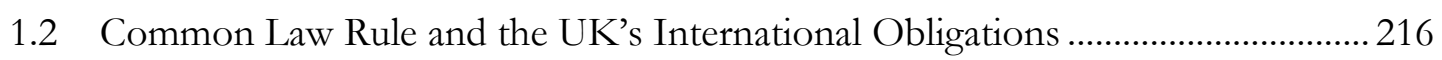

1.3 Common Law Rule and Infosoc Directive.............................................................. 219

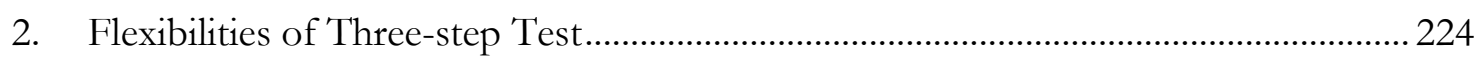

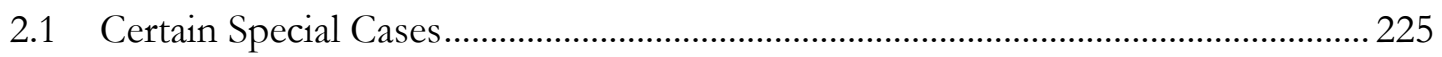

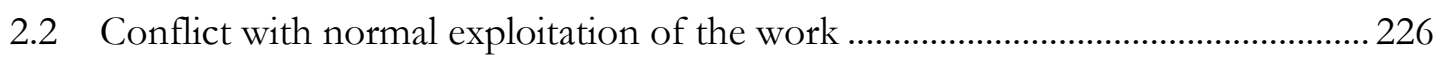

2.3 Unreasonable interfere with the legitimate interests of the right holder................ 228

3. Courts' Interpretation of Public Interest and Three-step Test........................................ 229

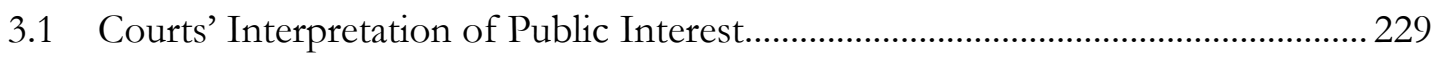

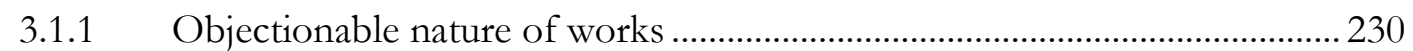

3.1.2 Need for disclosure of the work in public interest ........................................ 231

3.1.2.1 From breach of confidence to copyright infringement............................. 232

3.1.2.2 Copyright infringement and public interest ............................................ 236 
3.1.2.3 Cases considering s 171(3), CDPA............................................................... 239

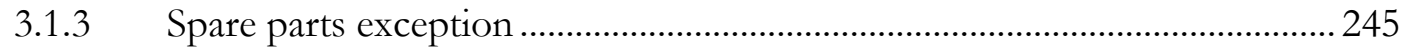

3.2 Three-step Test as a Methodological Guideline....................................................... 249

4. Interpretation of Public Interest and Fundamental Rights Regime.............................. 252

4.1 Fundamental Rights Methodology ………................................................................. 253

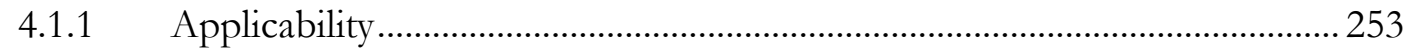

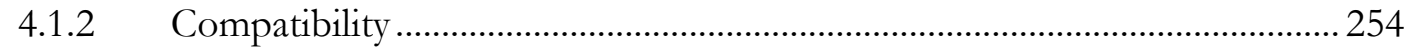

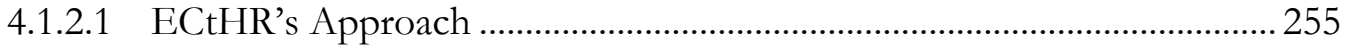

4.1.2.2 CJEU's approach..................................................................................... 258

4.2 ECtHR and CJEU decisions and the UK Courts ..................................................... 262

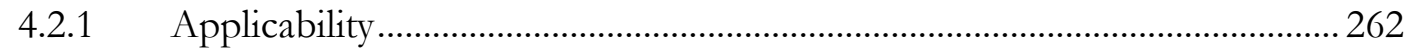

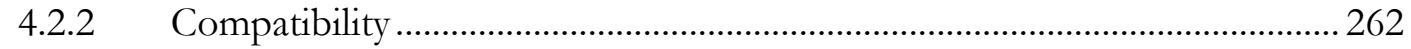

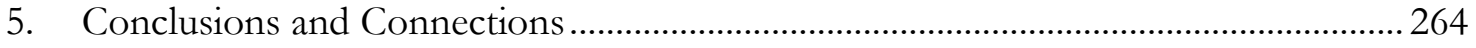

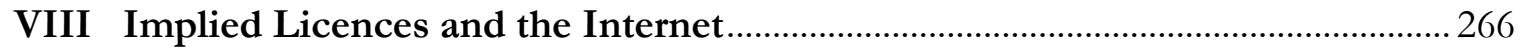

1. Content Placed by Copyright Owner or with her Consent ............................................268

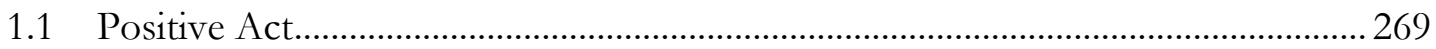

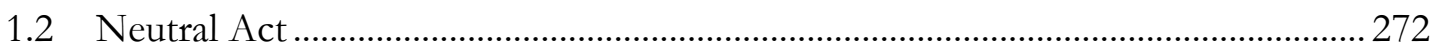

1.3 Knowledge of the Copyright Owner ...................................................................... 272

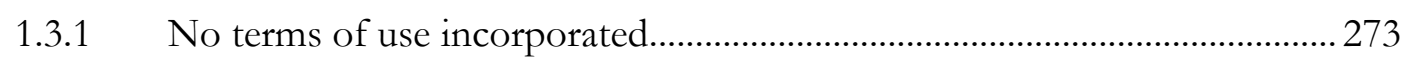

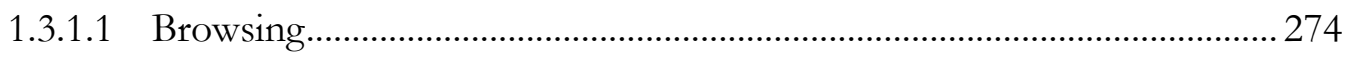

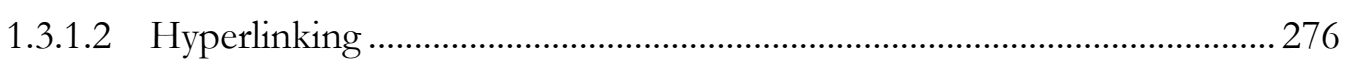

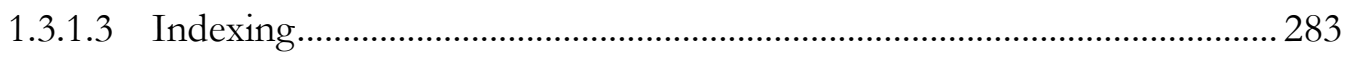

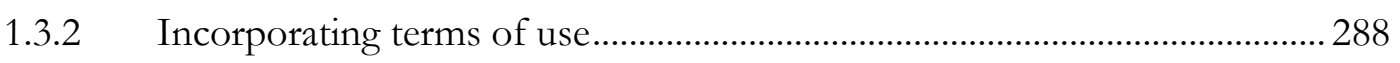

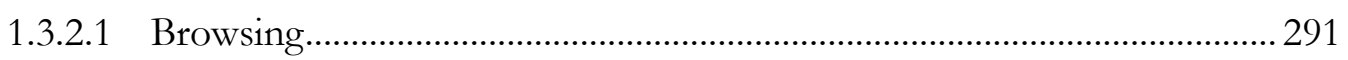

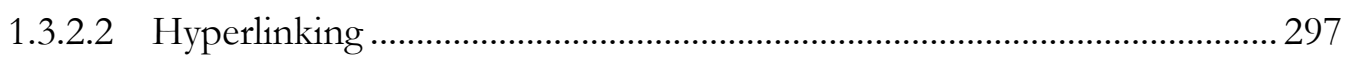

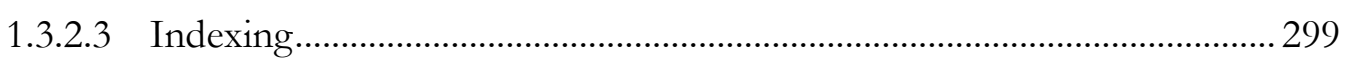

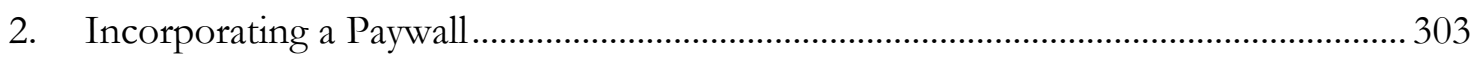

3. Content Placed without Copyright Owner's Consent ……........................................... 305

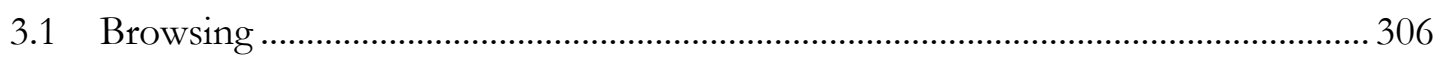

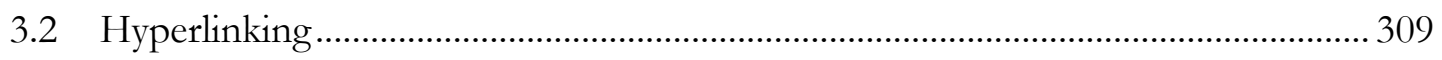

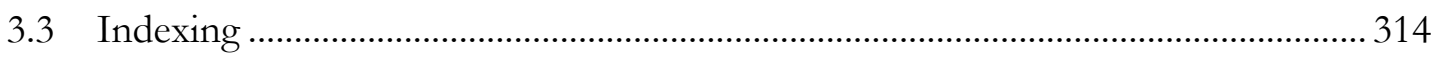

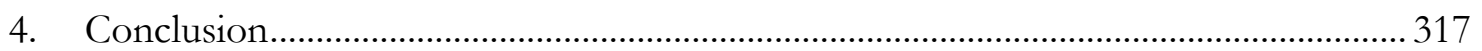

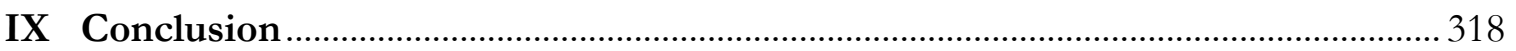

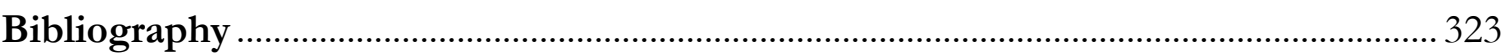




\section{Table of Abbreviations}

ACA

$\mathrm{BC}$

CDPA

CFREU

CRA

copyright work

ECHR

ECtHR

FR

HKCO

HRA

Infosoc Directive

L\&Es

$\mathrm{RC}$

SCA

SGA

TEU

TPM

TRIPS

UCTA

WCT

WIPO

WPPT
: Australian Copyright Act, 1968

: Berne Convention for the Protection of Literary and Artistic Works

: UK Copyright, Designs, Patents Act, 1988

: Charter of Fundamental Rights of the European Union

: UK Consumer Rights Act, 2015

: A work protected by copyright, as defined under s 1(2), CDPA

: European Convention on Human Rights

: European Court of Human Rights

: Fundamental rights

: Hong Kong Copyright Ordinance, 1997 (Cap 528)

: UK Human Rights Act, 1998

: Directive 2001/29/EC on the harmonisation of certain aspects of copyright and related rights in the information society

: Statutory Limitations and Exceptions

: International Convention for the Protection of Performers, Producers of Phonograms and Broadcasting Organisations (Rome Convention, 1961)

: Singapore Copyright Act, 1987

: Sale of Goods Act, 1979

: The Consolidated version of the Treaty on the European Union and the Treaty on the Functioning of the European Union

: Technological Protection Measures

: WTO Agreement on Trade Related Aspects of Intellectual Property Rights

: UK Unfair Contract Terms Act, 1977

: WIPO Copyright Treaty

: World Intellectual Property Organisation

: WIPO Performers and Phonograms Treaty 


\section{Table of Cases}

\section{United Kingdom}

A\&M Records Limited v Video Collection International Limited [1995] EMLR 25 .. 132

American Cyanamid v Ethicon Ltd [1975] UKHL 1 ...237

Anglo-African Merchants Ltd v Baylaey [1970] 1 QB 311 ... 176

Armstrong v Sheppard \& Short Ltd [1959] 2 QB 384 ... 115

Ashburn Anstalt v Arnold [1989] Ch 1 ... 14

Ashdown v Telegraph Group Limited

[2001] Ch 685 ... 242, 263

[2001] EWCACiv 1142 ... 63, 244, 250, 251, 262, 263, 264

Attorney General v Belize [2009] UKPC 10 ... 125, 126

Attorney General v Guardian Newspapers [1990] 1 AC 109 ... 230, 231

Banier v News Group Newspapers Limited [1997] FSR 812 ... 190

Banks v CBS Music [1996] EMLR 440 ... 11, 53, 66, 69, 73, 75, 81, 86, 87, 88, 95, 271

Banque Bruxelles SA v Eagle Star [1997] AC 191 ... 125

Barrett v Universal Island Records Ltd [2006] EWHC 1009 (Ch) ... 78, 79, 91, 92, 143, 166

Beck v Montana Constructions Pty Ltd 1963] FLR 298 ... 139, 150, 154, 155

Beckingham v Hodgens [2002]

EWHC 2143 (Ch) ... 71, 72, 73, 83, 85, 94, 108, 110, 113, 116

Beggars Banquet v Carlton [1993] EMLR 349 ... 236, 241, 249, 250, 251, 252

Beloff v Pressdram Limited [1973] FSR 33 ... 214, 233, 251

Betts v Willmott (1871) LR 6 Ch App 239 ... 201, 202, 204, 205, 209, 210

Blair v Osborne [1971] 1 All ER 468 ... 11, 43, 120, 129, 142-4, 146, 147, 149, 150, 154-6

BP Refinery (Westernport) Pty Ltd v Shire of Hastings (1978) 52 ALJR 20 ... 132

Brighton $v$ Jones

[2004] EWHC 1157 (Ch) ... 41, 69, 70, 72-3, 77-8, 81, 88-90, 95-6, 105, 115, 271

British Actors Film Co Ltd v Glover [1918] 1KB 299 ... 17

British Leyland Motor Company Ltd v Armstrong Patent Company Ltd

[1982] FSR 481 ... 188

[1984] FSR $591 \ldots 246$

[1986] 1 All ER 850 ... 204, 222, 246, 247, 248, 249, 251, 252

Canon Kabushiki Kaisha v Green Cartridge Co (Hong Kong) Ltd [1997] AC 728 .. 248

CBS United Kingdom Ltd v Charmdale Record Distributors Ltd [1981] 1 Ch 91 ... 18

Clearsprings Management Ltd $v$ Businesslinx Ltd

[2005] EWHC 1487 (Ch) ... 157, 169, 179, 185

Cobb v Yeoman's Row Management Ltd [2008] UKHL 55 ... 104

Confetti Records v Warner Music UK Ltd [2003] EWCH 1274 (Ch) ... 120, 161, 162

Coward v Phaestos Limited [2013] EWHC 1292 (Ch) ... 139, 140

Crossley v Faithful and Gould Holdings Lid, [2004] EWCA Civ 293 ... 198

Cunliffe-Owen v Teacher and Greenwood [1967] 1 WLR 1421 ... 35, 170, 171-73, 175, 179, 280

Danowski v The Henry Moore Foundation [1996] EMLR 364 (CA) ... 185, 186, 187

Drabble (Harold) Ltd v Hycolite Manufacturing Co, (1923-28) MCC 322 ... 131

Dunlop Pneumatic Tyre Co Ltd v Neal (1899) 16 RPC 247 ... 202

Dyson Ltd v Qualtex (UK) Ltd, [2005] IP \& T 656 ... 207

EMI Records Ltd v BSB Ltd [2013] EWHC 379 ... 264

Equitable Life Assurance Society v Hyman [2002] 1 AC 408 ... 122 
Express Newspapers plc v News (UK) Limited [1990] 3 All ER 376 .. 11, 189

Film Investors Overseas Services SAv The Home Video Channel Limited

[1997] EMLR 347 ... 96, 164

Fisher $v$ Brooker

[2006] EWHC 3239 (Ch) ... 71, 83, 91, 110, 112

[2008] EWCA Civ 287 ... 98

[2009] UKHL 41 ... 49, 83, 95, 98, 108

Fraser v Evans [1969] 1 QB 349 ... 235

Gabay v Lloyd [1825] 107 ER 927 ... 174

Glyn v Weston Feature Film Co [1916] 1 Ch 261 ... 230

Godfrey v Lees [1995] EMLR 307 ... 70, 71, 73, 79, 84-86, 90-96, 103-115

Goodwin v Roberts (1875) 1 App Cas 476 (HL) ... 171

Grisbrook v MGN Ltd [2009] EWHC 2520 (Ch) ... 165, 166, 169, 179, 185

Habib Bank Ltd v Habib Bank AG Zurich [1981] 1 WLR 1265 ... 103

Hall Brown v Iliffe \& Sons Lrd [1928-35] MCC 88 ... 188

Heap v Hartley (1889) 42 Ch D 461 ... 16

HRH Prince of Wales $v$ Associated Press [2006] EWHC 522 (Ch) ... 244, 250, 262, 263

Hubbard v Vosper [1972] 2 QB 84 ...232, 233, 234, 235, 237

Hyde Park Residence Ltd v Yelland

[1999] EWHC Patents 247 ... 231, 239

[2000] EWCA Civ 37 ... 214, 216, 231, 240, 241, 242

Infabrics Ltd v Jaytex Ltd [1981] 1 All ER 1057 .. 209

Initial Services Ltd v Putterill [1968] 1 QB 396 ... 232, 233, 234

Inwards v Baker [1965] 2 QB 29 ... 14

J H Rayner (Mincing Lane) Ltd v Department of Trade and Industry [1990] 2 AC 418 .. 219

Jennings $v$ Rice [2002] EWCA Civ 159 ... 97

Kammins Ballrooms Co Ltdv Zenith Investment (Torquay) Ltd [1971] AC 850 (HL) ... 100, 109

Keppell v Bailey (1834) 2 My \& K 517 ... 19

King $v$ David Allen [1916] 2 AC 54 ... 14

Kleinwort Benson Ltd v Lincoln City Council [1999] 2 AC 349 ... 171

Lamb v Evans [1893] 1 Ch 218 ... 188

Lion Laboratories Ltd v Evans [1985] QB 526 ... 234, 235, 237, 243, 249, 250-52

Liverpool City Council v Irwin [1977] AC 239 ... 132, 196, 197, 198

London Printing and Publishing Alliance (Ltd) v Cox [1891] 3 Ch 291 ... 16

Lucasfilms v Ainsworth

[2008] EWHC 1878 (Ch) ...137, 138

[2009] EWCA Civ 1328 ... 138

Luxor (Eastbourne) Ltd v Cooper [1941] AC 108 ... 124

Marks and Spencer plc v BNP Paribas [2015] UKSC 72 ...126, 127

Mars UK Ltd v Teknowledge Ltd [1999] EWHC 226 (Pat) ... 248

Massine v de Basil [1936-45] MCC 233 ... 131

Merryweather v Moore [1892] 2 Ch 518 ... 188

Muir Dorrans v The Shand Partnership 2003 Scot (D) 21/12 ... 149, 150, 156

National Provincial Bank v Ainsworth [1965] AC 1175 ... 15, 19

National Westminster Bank v Morgan [1985] AC 686 ... 176

Nelson v Dabl [1879] 12 ChD 568 ... 173

Nelson v Horniman (1909) 26 TLR 188 ... 16 
Newspaper Licensing Agency v Meltwater Holdings BV

[2010] EWHC 3099 (Ch) ... 3, 293, 294, 295, 296, 300, 317

[2011] EWCA Civ 890 ... 295

North and South Trust Co v Berkeley [1971] 1 WLR 470 ... 176

Pasterfield v Denham [1999] FSR 168 ... 130

PCR Limited v Dow Jones Telerate Limited [1998] FSR 170 ... 238

Perry v Barnett (1885) 15 QBD 388 ... 175

Philips Electronique Grand Public SA v BSB Ltd [1995] EMLR 472 ...123, 132

Port Line Ltd v Ben Line Ltd [1958] 2 QB $146 \ldots 17$

Produce Brokers Co Ltd v Olympia Oil \& Cake Co Ltd [1916] 2 KB 296 ... 174

Public Relations Consultants Association Limited v The Newspaper Licensing Agency Limited

[2013] UKSC 18 ... 266, 293, 296

R Griggs Group Limited v Evans

[2003] EWHC 2914 (Ch) ... 134, 135, 136, 137, 138

[2005] EWCA Civ 11 ... 135, 137

Ramsden v Dyson (1866) LR 1 HL 129 ... 98

Redwood Music Ltd v Chappell Co Ltd [1982] RPC 109 ... 162

Reid v Rush \& Tompkins Group Plc [1990] 1 WLR 212 (CA) ... 196

Reigate v Union Manufacturing Co (Ramsbottom) Ltd [1918] 1 KB 592 ... 124

Roberts v Candiware Limited [1980] FSR 352 ... 121, 168

Robin Ray v Classic FM

[1998] EWHC Patents 333 ... 131-136, 138, 140, 141, 150, 156-60, 271

Robinson v Mallett [1874-74] LR 802 ... 174

Sagar v H Ridehalgh \& Sons Ltd [1931] 1 Ch 310 ... 173

Saphena Computing Limited v Alliance Collection Agencies Ltd [1995] FSR 616 ...200, 208

Sawkins v Hyperion Revords Ltd [2004] EWHC 1530 (Ch) ...163, 164

Scally v Southern Health and Social Services Board [1992] 1 AC 294 (HL) ... 197, 198

Service Corporation International v Channel Four [1999] EMLR 83 ... 237, 241, 249, 251, 252

Shirlaw v Southern Foundries (1926) Ltd

[1939] 2 KB 206 ... 124

[1940] AC $701 \ldots 124$

Sirdar Rubber Company Limited v Wallington, Weston \& Co (1907) 24 RPC 539 ... 202

Solar Thomson Engineering Co Ltd v Barton [1977] RPC 537 ... 11, 202-209, 246, 292

Stockdale v Onwhyn [1826] 108 ER 65 ... 230

Stovin-Bradford v Volpoint Properties Ltd [1971] 3 All ER 570 ... 147, 148, 150, 154

Stratblorne Steamship Co Ltd v Hugh Bird \& Sons Ltd [1916] SC 134 (HL) ... 173, 177, 178

Taylors Fashions Ltd v Liverpool Victoria Trustees Co Ltd

[1982] QB 133 ... 101-103, 106-108, 111, 113

The Moorcock (1889) 14 PD 64 (CA) ... 124

Thomas v Sorrell (1672) Vaugh $330 \ldots$ 14, 15, 24, 188

Thorner v Major [2009] UKHL 18 ... 103

Tucker v Linger (1882) 21 Ch D 18 .. 178, 179

Twentieth Century Fox Film Corporation v BT plc [2011] EWHC 1981 (Ch) ... 262, 264, 308

Ultraframe UK Ltd v Clayton [2002] EWHC 1964 (Ch) ... 207

United Wire Ltd v Screen Repair Services (Scotland) Ltd [2001] FSR 24 ... 201, 203, 204, 205

Walter v Steinkopff [1892] 3 Ch 489 ... 190

Wilkinson v London Strategic Health Authority [2012] EWPCC 48 ... 151, 152, 153 
Willmott v Barber (1880) 15 Ch D 96 ... 98-110

Wood $v$ Wood (1823) 1 C \& P 59 ... 173

Woodward v Hutchins [1977] 1 WLR 760 ... 235

Australia

Acohs v R A Bashford Consulting (1997) 144 ALR 528 ... 239

Interstate Parcel Express Co Pty Ltd v Time-Life International (Nederlands) BV (1977) 138 CLR 534 ... 68

The Commonwealth of Australia v John Fairfax (1980) 147 CLR 39 .. 239

\section{Canada}

CCH Canadian Ltd v Law Society of Upper Canada [2004] SCC 13 ... 2, 40

\section{Court of Justice of the European Union}

Case 106/89 Marleasing SAv La Comercial International de Alimentacion SA [1990] ECR I-4135 ... 223

Case C-306/05 SGAE v Rafael Hoteles SL [2006] ECR I-11519 ... 277

Case C-275/06 Promusicae v Telefonica [2008] 2 CMLR 465 ... 261, 262, 264

Case C-5/08 Infopaq International v Danske Dagblades Forening [2009] ECR I-6569 ... 1, 275

Case C-403/08 FAPL v QC Leisure [2011] ECR I-9083 ... 296

Case C-70/10 Scarlet Extended v SABAM [2012] ECDR 4 ... 261, 262, 264

Case C-128/11 Used Soft GmbH v Oracle International Corp [2012] ECDR 19 ... 305

Case C-314/12 UPC Telekabel v Constantin Film [2014] ECDR 12 ... 254, 261, 264

Case C-466/12 Svensson v Retriever Sverige $A B$

[2014] ECDR 9 ... 259, 277-281, 299, 304, 312, 323

Case C-201/13 Deckmyn v Vanderstee [2014] WLR(D) 385 ... 254, 260, 264, 308

Case C-360/13 Public Relations Consultants Association v Newspaper Licensing Agency [2014] ECDR 22 ... 276

Case C-2/13 Opinion of the CJEU on Accession of the EU to the ECHR ECLI:EU:C:2014:2454 _.. 61

Case C-484/14 McFaddn v Sony Music [2016] WLR(D) 494 ... 254, 261

Case C-160/15 GS Media BV v Sanoma Media Netherlands BV ECLI:EU:C:2016:221, Opinion of AG Wathelet ... 283

Case C-160/15 GS Media BV v Sanoma Media Netherlands BV [2016] WLR(D) 477 ... 12, 260, 264, 283, 298, 312-314

Case C-527/15 Stichting Brein v Jack Frederik Wullems

ECLI:EU:C:2016:938, Opinion of AG Sanchez-Bordona ... 308, 309

ECLI:EU:C:2017:300 _.. 309

Case C-610/15 Stichting Brein v Ziggo

ECLI:EU:C:2017:99, Opinion of AG Szpunar ... 314

\section{European Court of Human Rights}

Ahmet Yildirim v Turkey App no 3111/10 (ECtHR, 18 December 2012) ... 258

Anheuser-Busche Inc v Portugal (2007) 45 EHRR 36 ... 254, 255

Ashby Donald v France App no 36769/08 (ECtHR, 10 January 2013) ... 257

Balan v Moldova App no 19247/03 (ECtHR, 29 January 2008) ... 256, 308 
Dima v Romania, App No 58472/00 (ECtHR, 26 May 2005) ... 255, 256

Frederik Neij v Sweden App no 40397/12 (ECtHR, 19 February 2013) .. 257

Times Newspapers Ltd v UK App nos 3002/03 and 23676/03 (ECtHR, 10 March 2009) ... 258

Wojtas-Kaleta v Poland App no 20436/02 (ECtHR, 16 July 2009) ... 258

\section{Germany}

Google Image Search (Vorschaubilder) Federal Supreme Court 2010 GRUR 628 ... 2, 302, 303, 316

Google Image Search (Vorschaubilder II) Federal Supreme Court

I ZR 140/10 of 19 October $2011 \ldots 316$

\section{Singapore}

Creative Technology Ltd v Aztech Systems Pte Ltd [1997] 1 SLR 621 ... 204, 205

\section{US}

Field v Google 412 F Supp 2d 1106 ... 2, 284, 287, 288

Ringold v Black Entertainment Television 126 F.3d 70 (2d Cir. 1997) ... 180

\section{WTO Panel Report}

Panel Rep. of 15 June 2000, United States-Article 110 (5) of the US Copyright Act WT/DS160/R ... 225-228 


\section{Table of Statutes and Treaties}

\section{United Kingdom}

Broadcasting Act, 1990

Schedule 17 ...42

Consumer Credit Act, 1974 ... 176

Consumer Rights Act, 2015

$$
\begin{aligned}
& \text { s } 1(1) \ldots 166 \\
& \text { s } 2(3) \ldots 166,167 \\
& \text { ss } 9-18 \ldots 199 \\
& \text { s } 34 \ldots 207 \\
& \text { ss } 34-41 \ldots 199 \\
& \text { s } 43(2) \ldots 207 \\
& \text { s } 49-53 \ldots 199 \\
& \text { s } 57 \ldots 178
\end{aligned}
$$

Copyright Act, 1911

$$
\begin{aligned}
& \text { s } 5(2) \ldots 17 \\
& \text { s. } 5(2) \text { proviso } \ldots 163
\end{aligned}
$$

Copyright Act, 1956

$$
\begin{aligned}
& \text { s } 2(5)(b) \ldots 209 \\
& \text { s } 3(5)(b) \ldots 209 \\
& \text { s } 4(3) \ldots 129 \\
& \text { s } 6 \ldots 227 \\
& \text { s } 19 \ldots 18 \\
& \text { s } 36(4) \ldots 18
\end{aligned}
$$

Copyright Designs and Patents Act, 1988

$$
\begin{aligned}
& \text { s } 1(1) \ldots 33 \\
& \text { ss } 3-8 \ldots 33 \\
& \text { s } 10(1) \ldots 74 \\
& \text { s } 11(1) \ldots 74,128 \\
& \text { s } 16(2) \ldots 1,17,128 \\
& \text { s } 22 \ldots 1,17 \\
& \text { s } 23 \ldots 1,17 \\
& \text { s } 28 \text { A } \ldots 275 \\
& \text { s } 30 \ldots 40,227,244 \\
& \text { s } 50 A \ldots 249 \\
& \text { s } 50 B \ldots 249 \\
& \text { s } 50 B A(1) \ldots 249 \\
& \text { s } 50 C \ldots 249 \\
& \text { s } 51 \ldots 207 \\
& \text { s } 66 \ldots 37 \\
& \text { s } 90(1) \text { and (4) . 17, 32, } 119 \\
& \text { s } 90(3),(4) \ldots 131 \\
& \text { s } 92(1),(2) \ldots 17,18,119 \\
& \text { s } 101(1) \text { and }(2) \ldots 18,133 \\
& \text { s } 101 \mathrm{~A}(1)-(5) \ldots 18 \\
& \text { s } 102 \ldots 18,133,136
\end{aligned}
$$




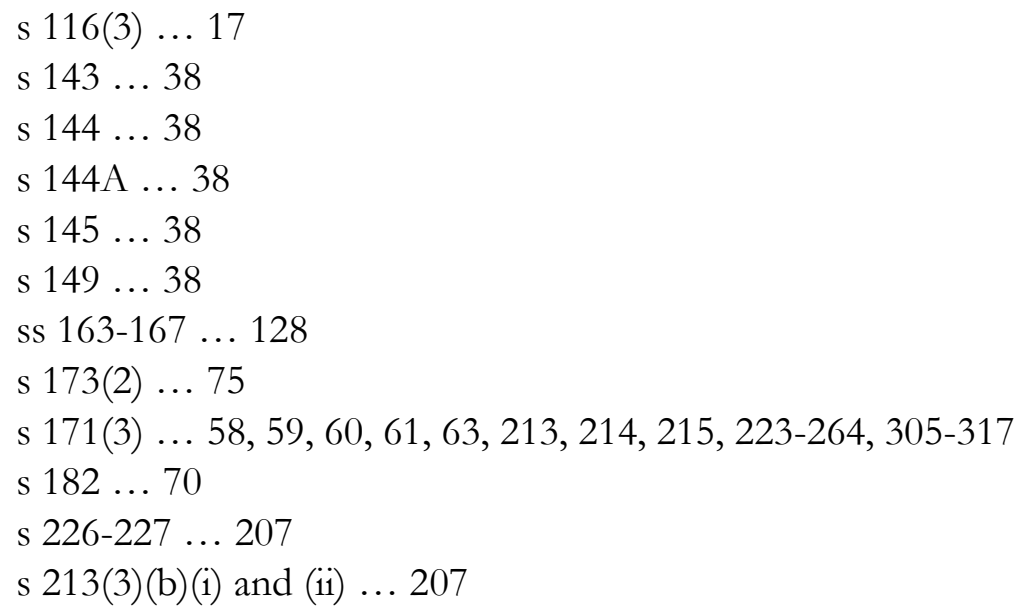

Copyright and Related Rights Regulations 2003 ... 228

Fine Arts Copyright Act, 1862 (25 \& 26 Vict. c. 68)

$$
\text { s } 3 \ldots 16
$$

Law of Property Act, 1925

$$
\begin{aligned}
& \text { s } 1(2)-(3) \ldots 15 \\
& \text { s } 62 \ldots 156
\end{aligned}
$$

Patents Act, 1977

$$
\text { s 60(1)(a) ... } 201
$$

Sale of Goods Act, 1979

$$
\begin{aligned}
& \text { s } 2 \ldots 206 \\
& \text { s } 12 \text { to } 14 \ldots 199,201 \\
& \text { s } 61(1) \ldots 206
\end{aligned}
$$

Supply of Goods and Services Act, 1982,

$$
\begin{aligned}
& \text { s } 2-5 \ldots 199 \\
& \text { s } 7-10 \ldots 199 \\
& \text { s } 13-15 \ldots 199
\end{aligned}
$$

Supply of Goods (Implied Terms) Act, 1973

$$
\text { ss } 8-11 \ldots 199
$$

Town and Country Planning Act, 1990

$$
\text { s } 75 \ldots 156
$$

Unfair Contract Terms Act, 1977 ... 176, 199

$$
\begin{aligned}
& \text { s } 2 \ldots 177 \\
& \text { s } 3 \ldots 177 \\
& \text { s } 6 \ldots 177,199 \\
& \text { s } 7 \ldots 177
\end{aligned}
$$

\section{Australia}

Copyright Act, 1968

$$
\begin{aligned}
& \text { s } 10(1) \ldots 17 \\
& \text { s } 35(2) \ldots 128 \\
& \text { s } 36(1) \ldots 1,17 \\
& \text { s } 37 \ldots 1,17 \\
& \text { s } 38(1) \ldots 1,17 \\
& \text { s } 101(1) \ldots 1,17 \\
& \text { s } 102(1) \ldots 1,17
\end{aligned}
$$




$$
\begin{aligned}
& \text { s } 103(1) \ldots 1,17 \\
& \text { s } 119 \ldots 18 \\
& \text { s } 120(1) \ldots 18 \\
& \text { s } 196(4) \ldots 17
\end{aligned}
$$

\section{Singapore}

Copyright Act, 1987

$$
\begin{aligned}
& \text { s } 30(2) \ldots 129 \\
& \text { s } 31(1) \ldots 1,17 \\
& \text { s } 32 \ldots 1,17 \\
& \text { s } 33 \ldots 1,17 \\
& \text { s } 103(1) \ldots 1,17 \\
& \text { s } 104(1) \ldots 1,17 \\
& \text { s } 105(1) \ldots 1,17 \\
& \text { s } 123 \ldots 18 \\
& \text { s } 124 \ldots 18 \\
& \text { s } 194(4) \ldots 17
\end{aligned}
$$

\section{Hong Kong}

Copyright Ordinance, 1997 (Cap 528)

$$
\begin{aligned}
& \text { s } 13 \ldots 129 \\
& \text { s } 15 \ldots 129 \\
& \text { s } 22(2) \ldots 1,17 \\
& \text { s } 30 \ldots 1,17 \\
& \text { s } 31(1) \ldots 1,17 \\
& \text { s } 32(1) \ldots 1,17 \\
& \text { s } 101(4) \ldots 17 \\
& \text { s } 103(1)-(2) \ldots 17,18 \\
& \text { s } 112 \ldots 18 \\
& \text { s } 113 \ldots 18
\end{aligned}
$$

\section{United States}

Copyright Act, 1976

$$
\begin{aligned}
& \text { s } 107 \ldots 218 \\
& \text { s } 110(5)(b) \ldots 225
\end{aligned}
$$

\section{EU Directives}

E-Commerce Directive (2000/31/EC) art $14 \ldots 316$

Information Society Directive (2001/29/EC) recital $3 \ldots$ 224, 259, 264, 308

recital $31 \ldots 1,37,223,259$

recital $32 \ldots 2,219,222,224$

recital $33 \ldots 296$

art 3(1) .. 277, 281

art 3(3) .. 277, 278 


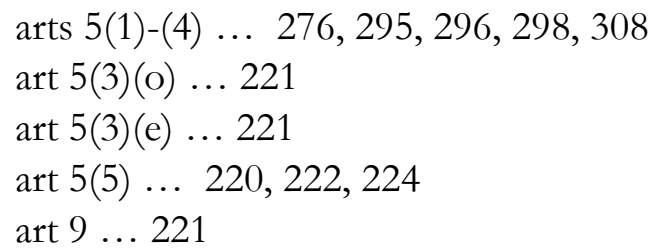

Software Directive (2009/24/EC)

art $5 \ldots 207$

\section{Treaties}

Berne Convention

$$
\begin{aligned}
& \text { art } 9(2) \ldots 218,219 \\
& \text { art } 17 \ldots 217
\end{aligned}
$$

Charter on Fundamental Rights of the European Union

art $11 \ldots 260,261,307,308,311,312,315$

art $16 \ldots 262,314,315$

art 17(2) .. 259, 260, 261, 307, 308, 311

art 51(1) ...252

art $52 \ldots 259,307$

art 53 ... 259

European Convention on Human Rights

art $10 \ldots 257,258,263,307,308,311,315$

art $19 \ldots 252$

art 46(1) ...252

art 1, First Protocol ... 255, 256, 257, 263, 308, 311

Rome Convention

arts $7,12,13 \ldots 195,219$

art 15(2) ... 195, 219

Treaty of the European Union

$$
\begin{aligned}
& \text { art } 6(1) \ldots 62 \\
& \text { art } 6(2) \ldots 61 \\
& \text { art } 50 \ldots 6 \\
& \text { art } 267 \ldots 6252
\end{aligned}
$$

Treaty on Trade Related aspects of Intellectual Property Rights (TRIPS)

art $13 \ldots 218$

art $9(1)$ and $(2) \ldots 218$

WIPO Copyright Treaty

art $10 \ldots 224$

WIPO Performers and Phonograms Treaty

art $16 \ldots 224$

\section{European Union Documents}

Recommendations to national courts in relation to the initiation of preliminary ruling proceedings [2012] OJ C338/12 ... 253

Amendment to TEU by Treaty of Lisbon [2007] OJ C306/01... 60 


\section{List of Tables and Charts}

Chart I Implied licence covering the spectrum between L\&Es and Page 10 express licence

Table I Implying a policy-based licence Pages 56-7

Chart II How the facts and circumstances flow through the frameworks Page 322 


\section{Introduction}

Copyright infringement in many jurisdictions is defined as the doing of a restricted act "without the licence of the copyright owner.' An express licence granted by the copyright owner is the most common example of such a licence. Recognising the need to balance competing interests of different stakeholders, including those of the copyright owners and the content users, ${ }^{2}$ copyright law in most countries also provides for statutory limitations and exceptions (L\&Es). ${ }^{3}$ The L\&Es address specific instances of permitted uses of copyright works to achieve specific policy objectives. If a certain use is not authorised by either an express licence of the copyright owner or by the L\&Es, such use does not automatically amount to an infringement. It may be possible to imply a licence to cover these uses. Implied licences in copyright law, which span the spectrum between express licences at one end, and the L\&Es at the other, are the focus of this thesis (See Chart I at the end of this Chapter).

There are several advantages to focusing on licences, rather than the L\&Es. A licence is integral to the definition of infringement, in that the existence of a licence negates infringement. L\&Es on the other hand, both within the scheme of copyright statutes and conceptually, are external defences, or as the name suggests, exceptions to copyright. As exceptions to the rule of protecting copyright, the L\&Es are interpreted narrowly. ${ }^{4}$ The list of

\footnotetext{
${ }^{1}$ CDPA, s 16(2), 22, 23, 24. ACA, ss 36(1), 37(1) and 38(1), and 101(1), 102(1) and 103(1); SCO, ss 31(1), 32, 33, and 103(1), 104(1) and 105(1); HKCO, ss 22(2), 30, 31(1), 32(1).

${ }^{2}$ Recital 31, Infosoc Directive, states that 'A fair balance of rights and interests between the different categories of rightholders, as well as between the different categories of rightholders and users of protected subject-matter must be safeguarded.' See also preamble to WIPO Copyright Treaty.

${ }^{3}$ CDPA, Part I, Chapter III.

${ }^{4}$ Case C-5/08 Infopaq International A/S v Danske Dagblades Forening [2009] ECR I-6569 [56]-[57].
} 
specific instances of permitted uses in many jurisdictions is exhaustive. ${ }^{5}$ Further, in the UK, since the enactment of the amendments to Part I, Chapter III of the CDPA in 2014, a term of a contract that restricts or prevents the respective L\&Es taking effect is unenforceable. Thus, the L\&Es can be regarded as users' rights, enforceable against copyright owners to use copyright works in certain specific circumstances. ${ }^{6}$

However, a licence, being part of the infringement discourse, does not suffer from these constraints. A licence does not have to only address a pre-determined set of permitted uses, nor does it have to be necessarily interpreted narrowly. Indeed, the strength of licences lies in their flexibility to address a diverse set of circumstances. Implied licences can respond to a broader range of situations, beyond those addressed by the users' rights. The manner in which a licence is implied, therefore, holds the key to a range of uses being permitted, which otherwise may have infringed copyright.

Understandably, copyright owners fear that a broader recognition of implied licences may authorise a wider use of copyright works than the owners find acceptable. For users of copyright content, on the other hand, implied licences could legitimate a variety of beneficial uses of copyright works. In particular, implied licences could ensure that end-users are not infringing copyright while performing the most basic functions on the internet. Implied licences could thus make the application of copyright law fairer and more efficient.

The doctrine of implied licence was brought to focus in recent times as a response to copyright infringement online, in particular, by the $\mathrm{US}^{7}$ and German ${ }^{8}$ courts. The UK courts

\footnotetext{
${ }^{5}$ Infosoc Directive, recital 32.

${ }^{6}$ See for example, the Canadian case of CCH Canadian Ltd v Law Society of Upper Canada [2004] SCC 13 [12].

${ }^{7}$ For example, Field v Google 412 F Supp 2d 1106.

${ }^{8}$ For example, Google Image Search (Vorschaubilder) Federal Supreme Court, 2010 GRUR 628.
} 
too have had the opportunity to imply copyright licences in the analogue environment, but none thus far on the internet. ${ }^{9}$ The case law however, is often lacking in transparency as to why judges come to the conclusions they do. As a result, uncertainty surrounds the implication of copyright licences.

Implication as a process is no stranger to law. It occurs to mention the implication of easements, warranties and terms in a contract. Implication in any area of law is contentious because of the discretion it gives the courts to imply as they deem fit. To guide the exercise of such discretion in these contexts, courts have formulated principles of implication. Likewise, one needs a methodology to govern the implication of a copyright licence. Otherwise, it could result either in implying licences indiscriminately, undermining the rights of the copyright owner; or, in the courts exercising undue conservatism in implying a licence, denying the users of copyright works unfairly of certain socially beneficial uses.

My research is aimed at allaying fears of unguided discretion and uncertainty surrounding implied copyright licences that have prevented their greater embrace by courts thus far. The objective of my research, therefore, is to propose frameworks for implying copyright licences arising in different circumstances, in a methodical and transparent manner. At the same time, I am conscious not to insist on the frameworks as a rigid or inflexible set of guidelines for the courts to follow; lest the much-valued flexibility of implied licences could be lost. The frameworks try to balance between guidance and flexibility.

In this thesis, I have focussed on the UK law, and EU law to the extent applicable. I have also drawn significantly on the common law doctrine of property law and contract law. Although common law jurisdictions have similar principles of copyright law and private law,

\footnotetext{
${ }^{9}$ In Newspaper Licensing Agency v Meltwater Holdings BV [2010] EWHC 3099 (Ch), a case on the legality of internet browsing, the judge acknowledged that she was taken to no authority on implied licence. ibid [100].
} 
UK law has been influenced by EU law in ways that other common law countries have not been. In focusing only on the UK, my aim is to provide the depth of analysis, which might not be possible if I were to cover many jurisdictions within the space available here. The study of a single jurisdiction results in a more self-contained research, avoiding the danger of being lost in detail. Nevertheless, I do address Australian, Singaporean and Hong Kong law, and Canadian case law to a limited extent, especially where the authorities in the UK are insufficient to illustrate the point being made. I have referred to certain decisions of the US and German courts in Chapter VIII, ${ }^{10}$ due to the paucity of cases relating to the internet decided by the UK courts. Unless otherwise mentioned, all reference to statutes are to the UK statues.

The extent of the influence of EU law on the UK might change in the near future, since the people of the UK have voted in a referendum to leave the EU. ${ }^{11}$ Accordingly, the UK Government has triggered the process of leaving the EU. ${ }^{12}$ It is possible that upon leaving, the UK might not seek to regain the membership of the internal market, ${ }^{13}$ in which case the UK will not be bound by the EU treaties or directives. ${ }^{14}$ The impact of what is commonly called 'Brexit', on implied copyright licences is discussed further in Chapter VII below.

Regarding the existing literature, the UK textbooks do deal with implied copyright licences, but to different degrees of detail. While some of them are descriptive in their coverage of the relevant case law, they do not provide a systematic analysis. For instance, until its 2016 edition, one textbook made no distinction between an implied bare licence and an implied

\footnotetext{
10 See (n 7) and (n 8).

11 <http://www.bbc.co.uk/news/politics/eu_referendum/results> accessed 10 February 2017.

$12<$ https://www.ft.com/content/22c0d426-1466-11e7-b0c1-37e417ee6c76> accessed 4 April 2017.

13 <http://www.bbc.co.uk/news/uk-politics-38641208> accessed 10 February 2017.

14 TEU, art 50.
} 
contractual licence. ${ }^{15}$ Another textbook, while providing some classification of implied licences (such as commissioning contracts, implied licence to repair), discusses no methodology of implying a licence. ${ }^{16}$ Certain other textbooks mention briefly, only the possibility of implying a copyright licence. ${ }^{17}$

There is some commentary in the journal articles, on the application of implied licences to online copyright infringement, but with specific reference to the US or German law. I do refer to the commentary on German case law to some extent, bearing in mind that the concept of licence under German law is different from that in the UK law. ${ }^{18}$ Some US commentators believe that for implied licence to be applied on the internet, it must be expanded from its traditional understanding, which they assert is within contract law. ${ }^{19}$ There is also a case made for implied licence as a 'new standard' that would make sense of copyright law on the internet. ${ }^{20}$ However, this thesis argues that as far as the UK law is concerned, one does not need the expansion of implied licence, but a methodical way of understanding the existing doctrine. Indeed, I will show in Chapter VIII how implied licences understood in the analogue world can be applied to imply licences online.

\footnotetext{
15 Compare Kevin Garnett, Gillian Davies and Gwilym Harbottle, Copinger and Skone James on Copyright $\left(16^{\text {th }}\right.$ edn, Sweet \& Maxwell, 2011) para 5-217 ff, with Gillian Davies, Nicholas Caddick and Gwilym Harbottle, Copinger and Skone James on Copyright (17 th $\mathrm{edn}$, Sweet \& Maxwell 2016) para 5-244 ff.

${ }^{16}$ Mary Vitoria, et al, Laddie, Prescott and Vitoria's Modern Law of Copyright (4th edn, LexisNexis, 2011) para 25.15 ff.

${ }^{17}$ Lionel Bently and Brad Sherman, Intellectual Property Law (4th edn, OUP 2014) 299-300; William Cornish, David Llewelyn and Tanya Aplin, Intellectual Property (8th edn, Sweet \& Maxwell 2013) para 13-13.

18 Tanya Pihlajarinne, 'Setting the Limits for the Implied License in Copyright and Linking Discourse - The European Perspective' [2012] 43(6) IIC 700.

${ }^{19}$ John Sieman, 'Using the Implied Licence to Inject Common Sense into Digital Copyright', [2007] 85 NCL Rev 885, 906; Orit Fischman Afori, Implied Licence: An Emerging New Standard in Copyright Law, [2009] 25 Santa Clara Computer \& High Tech LJ 275, 291.

20 Afori (n 19) 291-295.
} 
My thesis goes beyond the existing literature on implied licences in several ways. It begins with questioning the very conception of a licence in the existing doctrine, which is inadequate to explain copyright licences. Although copyright is regarded as a form of personal property, the notion of licence in personal property is largely focused on distinguishing between bailment and licences, which does not help in explaining copyright licences. ${ }^{21}$ One might consider the notion of implied licence in patent law as a better starting point, since patent law relies on implied licences in connection with the doctrine of exhaustion. ${ }^{22} \mathrm{I}$ address this briefly in Chapter VI. However, as stated in Chapter II, even if the notion of a patent licence might pre-date that of a copyright licence, in these cases the notion of 'licence' as such is still derived from land law. Therefore, land law becomes a default starting point. However, I demonstrate that for copyright law to rely on land law notion of a licence is unhelpful. Therefore, I turn to the Hohfeldian analytics for guidance.

Commentators have used Hohfeldian analytics to explain licences generally, and Christopher Newman has used the analytics in relation to copyright licences. However, Newman's chief focus in engaging with Hohfeldian analytics is to dispel the notion widely held in the US that a licence is a contract not to sue, and to establish that a copyright licence is a property interest. ${ }^{23}$ Newman's work, however, focuses solely on the US law. Therefore, I rely on Newman's work only to the extent that Hohfeldian approach is used to bring clarity into the understanding of copyright licences. Establishing a copyright licence as a property interest is not the central theme of my thesis. However, I do show that there are unique provisions in

\footnotetext{
${ }^{21}$ Norman Palmer, Palmer on Bailment ( $3^{\text {rd }}$ edn, Sweet \& Maxwell 2009) 377-410.

22 Bently and Sherman (n 17) 616-17.

${ }^{23}$ Christopher Newman, "A License is not a "Contract not to Sue": Disentangling Property and Contract in the Law of Copyright Licenses [2013] 98 Iowa Law Review 1101.
} 
the CDPA (and indeed in other common law jurisdictions) that signal the need for a different approach to copyright licences, rather than simply relying on the land law notion. ${ }^{24}$

Based on the Hohfeldian notion of a licence, Newman also explores implied copyright licences in a related work. ${ }^{25}$ However, Newman's work provides a critical analysis of the positive law in the US, demonstrating the different circumstances in which courts have implied copyright licences. I go a step further in using Hohfeldian analytics normatively to propose frameworks for implying copyright licences arising under different circumstances, as guidelines for the courts to adopt when dealing with cases of copyright infringement.

Newman's analysis of the doctrine of implied licence only reveals licences implied by consent and by custom, although the notion of what amounts to a custom in the US is also quite different from the UK. In my thesis, in addition to consent and custom, I also address the implication of copyright licences due to the intervention of the state for public policy reasons. Although the UK textbooks do refer to licences implied by custom, there has been no systematic study of how the state can intervene to imply a copyright licence, which I provide in my thesis. ${ }^{26}$

My thesis therefore, identifies three sources of implication - consent of the copyright owner, custom and state intervention. These are similar to the bases that support the implication of a term in a contract - implied in fact, implied by custom and implied by law. Each of these is a source of private or public ordering that applies as much to the actions of

\footnotetext{
${ }^{24}$ See Chapter II, section 1.2 below.

${ }^{25}$ Christopher Newman, "What Exactly are you Implying?": the Elusive Nature of the Implied Copyright Licence’ [2013-14] 32 Cardozo Arts \& Ent LJ 501.

${ }^{26}$ See however, Bently and Sherman (n 17) 299, where there is a brief discussion on the method of implying a term by law into a contract. I do refer to this in Chapter VI below. My methodology of implying a policy-based bare licence goes further, as described in Chapter VII below.
} 
persons vis-à-vis other persons (such as entering into a contract), as it does to the actions of persons vis-à-vis property (such as granting a licence). A person may voluntarily negotiate contract terms, in the same way as she may voluntarily consent to her property being used. A custom can regulate the contracting behaviour of the parties in a trade/industry, just as it can regulate how a person can use her property within a trade/industry. Similarly, a law can regulate the terms of a contract, as much as it can regulate how a person can use her property.

The sources of implication aside, one may wonder as to how the contractual rules on implication of terms map on to the frameworks I propose. Based on Hohfeldian analytics, I argue that a licence is not a contract, although it can arise within a contractual context. ${ }^{27}$ This facilitates the distinction between a bare licence and a contractual licence. In general, the frameworks I propose in relation to bare licences are different from the rules of implication of terms in a contract. ${ }^{28}$ While implying a licence into a contract, I do consider and follow the rules of implication by custom ${ }^{29}$ and implication by law. ${ }^{30}$ However, I do not follow the rules of implication in fact, for the reasons explained in Chapter IV.

A copyright licence, when implied, broadens the permitted uses, which means a narrower scope for infringement, and thus, greater protection against infringement for copyright users. One might assume that the very reason for focusing on implied licences is to enable expansion of permitted uses, and thereby enhance user protection. With the expansion in the owners' rights, and the rigidity of user' rights to deal with the challenges of the changing copyright landscape, copyright balance might prompt in the direction of expansion of

\footnotetext{
${ }^{27}$ See Chapter II, section 1.3 below.

${ }^{28}$ See Chapters III and VII below.

${ }^{29}$ See Chapter V below.

${ }^{30}$ See Chapter VI below.
} 
permitted uses by implying a copyright licence. Although this is one of the ways in which my thesis views copyright balance, my thesis is not premised on the assumption that broadening permitted uses is always a desirable or an appropriate outcome. This is because copyright users form a disparate group, ranging from a record company or a film production house, with significant bargaining power, to an individual internet user, who may never approach a court to defend her ability to access or use information on the internet. Therefore, not all copyright users form a vulnerable group requiring additional protection by the expansion of permitted uses. By the same token, copyright owners also form a disparate group, ranging from commercially successful authors, record companies and film producers to up-and-coming struggling authors. ${ }^{31}$ For implied licences to produce a meaningful and just result for all parties concerned, there should be no bias leaning always in favour of expanding permitted uses. Additionally, the credibility of the frameworks for implying these licences is enhanced if they are unbiased and balanced. Thus, the flexibility inherent in implied copyright licences as the middle ground between owners' rights and users' rights allows a more balanced approach to copyright balance itself.

With this background, I move to Chapter II, where I propose frameworks for implying copyright licences arising under different circumstances. These frameworks are built by analysing inductively the existing doctrine on copyright licences, both express and implied, through the prism of Hohfeldian analytics. The effort through the rest of the thesis is to demonstrate that applying the frameworks to rationalise the existing case law can make the process of implication methodical and transparent. The framework is thus proposed as a tool for the courts to apply when faced with a case of copyright infringement.

\footnotetext{
${ }^{31}$ See Chapter III, section 1.3.2 below, for a discussion on the poor bargaining power of background musicians in the music industry.
} 


\section{Chart I}

\begin{tabular}{|c|c|c|c|c|c|c|}
\hline \multirow{3}{*}{$\begin{array}{l}\text { Owners' rights } \\
\text { licensed } \\
\text { expressly by } \\
\text { the copyright } \\
\text { owner }\end{array}$} & \multicolumn{5}{|c|}{$\longleftarrow$ Implied Copyright Licences $\longrightarrow$} & \multirow[b]{3}{*}{$\begin{array}{l}\text { Users' rights } \\
\text { represented by } \\
\text { statutory } \\
\text { limitations and } \\
\text { exceptions }\end{array}$} \\
\hline & \multicolumn{2}{|c|}{$\begin{array}{l}\text { Consent } \\
\text { based }\end{array}$} & \multirow{2}{*}{$\begin{array}{l}\text { Custom } \\
\text { based } \\
\text { Implied } \\
\text { Bare and } \\
\text { Contractual } \\
\text { licence }\end{array}$} & \multicolumn{2}{|c|}{$\begin{array}{l}\text { Policy } \\
\text { based }\end{array}$} & \\
\hline & $\begin{array}{l}\text { Implied } \\
\text { Bare } \\
\text { Licence }\end{array}$ & $\begin{array}{c}\text { Implied } \\
\text { Contractual } \\
\text { Licence }\end{array}$ & & $\begin{array}{c}\text { Implied } \\
\text { Contractual } \\
\text { Licence }\end{array}$ & $\begin{array}{l}\text { Implied } \\
\text { Bare } \\
\text { Licence }\end{array}$ & \\
\hline & & 1 & ectrum co & ing & & \\
\hline
\end{tabular}

900) 


\section{The Proposed Frameworks}

[T] he chameleon-hued term, "license" (...) may be said to be a word of convenient and seductive obscurity; $(. . .)^{1}$

Thus remarked Wesley Newcomb Hohfeld, while commenting on the distinction between easements and licences. The complexity of issues presented extends to copyright licences. The complexity deepens when a licence is not granted expressly, but must be implied. Consider the following scenarios involving copyright works:

(a) A has been invited to sing in a rock band. B helps A as a friend, by writing the lyrics of the song and giving them to A. ${ }^{2}$ A sells the lyrics to $\mathrm{C}$, a member of the band. Can A do this?

(b) A engages $\mathrm{B}$ for a fee, to draw the architectural plans to build a house. ${ }^{3} \mathrm{~B}$ draws the plans and gives them to A. A pays B the fee, and then engages another architect C, to build the house based on the same plans. Can A do this?

(c) A, a newspaper, publishes a story incorporating certain quotes from an interview first published in a competing newspaper $\mathrm{B}$, on the basis that there is a custom that allows such copying. ${ }^{4}$ Can A do this?

(d) A, a repair service provider, makes spare parts to order, knowing that the copyright in the design of the spare parts belongs to B, but does so without B's permission. ${ }^{5}$ Can A do this?

(e) A provides a hyperlink on her website to external content online, knowing that the

\footnotetext{
1 Wesley Newcomb Hohfeld, 'Faulty Analysis in Easement and Licence Cases’ [1917] 27 Yale LJ 66, 92.

${ }^{2}$ Banks v CBS Music [1996] EMLR 440.

${ }^{3}$ Blairv Osborne [1971] 1 All ER 468.

${ }^{4}$ Express Newspapers plov News (UK) Limited [1990] 3 All ER 376.

5 Solar Thomson Engineering Co Ltd v Barton [1977] RPC 537.
} 
content to which the link leads infringes B's copyright. ${ }^{6}$ Can A do this?

As these examples relate to diverse circumstances, it may be difficult to see a common theme running through them. Indeed, do all the scenarios even present facts involving a 'licence'? Do we know what constitutes a licence, so that in each of the scenarios above, we can identify the constituents? In some scenarios like (c), (d) and (e) above, B, the copyright owner does not appear to have consented to the actions of A. Can a licence arise in the absence of consent? There is no express grant in any of the scenarios. Therefore, if a licence is to be implied, is there a method of implying licences? How is one to accommodate the diversity of circumstances in which licences arise? Can we develop frameworks for implying a copyright licence under different circumstances, in a methodical and transparent manner?

In scenarios (a) and (b) above, if B had expressly conveyed to A the uses which A can make of the respective works, then a court would seek the proof of the express words. In the absence of the express words, we need a way to assess B's conduct and the surrounding circumstances, to convince the court to imply a licence. In scenario (c), we need a way to ascertain how a practice becomes a custom, so that we may persuade the court to imply a licence based on such custom. In scenarios (d) and (e), we need a way to ascertain if a court is empowered to give effect to the respective policy objectives, beyond those captured by the L\&Es, so that a licence may be implied on that basis.

However, in the above scenarios, one might assume that one knows what constitutes a licence. This is not necessarily true, as section 1 of this Chapter demonstrates. Copyright law does not spell out what constitutes a licence, but has historically relied on land law conception of a licence. The primary focus of land law on licences has been to emphasise the residuary

\footnotetext{
${ }^{6}$ C-160/15 GS Media BV v Sanoma Media Netherlands BV [2016] WLR(D) 477.
} 
nature of a licence after other property interests in land are defined. Since land law offers little help in identifying the constituents of a licence, this section turns to Hohfeldian analytics to identify broadly the constituents of a licence that may arise generally under any circumstance.

Having gained a general conception of licence, section 2 narrows down the context to copyright licences, and identifies ways in which express copyright licences arise. The key to understanding how one may imply a copyright licence is to delve into how express copyright licences arise. Copyright law recognises three sources of power, the exercise of which can grant express copyright licences. These are: (a) powers of a copyright owner to consent voluntarily for the grant of a licence; (b) a practice established as a custom within a trade/industry enabling the grant of a licence; and (c) the intervention of the state to issue compulsory licences to achieve a public policy goal.

Section 3 proposes frameworks for implying copyright licences that arise under different circumstances. It draws on the constituents of a licence identified in section 1, and the sources of power that create an express copyright licence identified in section 2. Invoking the same sources of power that give rise to express copyright licences also for implying a copyright licence brings legitimacy to the process of implication. The fears of undue exercise of a court's discretion in implying a licence can be curtailed by limiting the court to what are known to be the sources of power for the express copyright licences to arise.

Section 4 concludes by explaining how in the remaining chapters, the existing case law is rationalised in the light of the frameworks proposed.

\section{Constituents of a Licence}

Although licensing is one of the most important ways of transacting in exclusive rights, copyright law throws little light on the nature and the constituents of copyright licences. Instead, copyright law follows the principles of land law on licences. Therefore, we explore 
below, land law on licences to ascertain its helpfulness in finding the constituents of a licence.

\subsection{Land Law on Licences}

Much of land law on licences is common law. Land law relies on Thomas v Sorrell for its definition of a licence, although the facts of this case had nothing to do with land. The claimant, Thomas, acting on behalf of the Crown, demanded payment from the defendant, Sorrell, on the basis that the defendant sold wine in a parish without a licence, as required by the relevant statute at the time. Sorrell's defence was that he did have a licence granted by the Crown. While describing what a licence is Vaughan J said: ${ }^{7}$

A dispensation or licence properly passeth no interest, nor alters or transfers property in any thing, but only makes an action lawful, which without it had been unlawful. As a licence ... to hunt in a mans park, to come into his house, are only actions, which without licence, had been unlawful.

Modern land law interprets Thomas to mean that a licence is a "personal permission to use land belonging to another that, without such permission, would amount to a trespass. ${ }^{8}$ This means that a licence can only be enforced against the person who grants it. It does not run with the land, and cannot be enforced against purchasers or transferees of the land over which it exists. ${ }^{9}$ Purchasers might become bound under certain circumstances such as where a constructive trust is found, ${ }^{10}$ or proprietary estoppel exists. ${ }^{11}$ But the general nature of a licence in land is that it does not bind successors in title, and therefore is not a property interest. ${ }^{12}$

\footnotetext{
7 Thomas v Sorrell (1672) Vaugh 330, 351.

8 Martin Dixon, Modern Land Law (10 th edn, Routledge 2016) para 9.2(1) (emphasis in the original).

9 ibid para 9.2(5); see also King v David Allen [1916] 2 AC 54, 60, 62.

10 Ashburn Anstalt v Arnold [1989] Ch 1.

${ }^{11}$ Inwards v Baker [1965] 2 QB 29, 37.

${ }^{12}$ Dixon (n 8) paras 9.2(5), 9.3.6 and 9.3.7.
} 
Another consequence of a licence being personal is that a licensee is normally unable to sue for trespass or nuisance in her own right. Only a licensor who has a property interest in land can bring these actions. ${ }^{13}$ Although a licensee in exclusive possession of the land might be able to sue in her own right, it may only be under certain circumstances; as a general rule, she does not have such rights. ${ }^{14}$

The House of Lords has held that for an interest to be proprietary, it must be definable, identifiable and capable of being assumed by third parties, and have some degree of permanence and stability. ${ }^{15}$ Accordingly, scholars have argued that it is necessary for licences to be conceptualised as non-proprietary in order to accommodate the diverse informal and transient uses of land, such as inviting someone home for dinner. It can hardly be said that the person attending the dinner thereby acquires a 'property interest in land.' In addition, property interests normally require formalities for their creation, ${ }^{16}$ which is too burdensome for transient and informal uses of land. Further, in land law, there is a closed list of property interests that can be recognised (numerus clausus), ${ }^{17}$ and a person holding title to land is not free to add to the list by simply declaring licences to be property interest. ${ }^{18}$ For these reasons, land law places licence in a 'residuary category', and conceptualises it as 'any right to enter land that does not fit into one of the recognised property categories'. ${ }^{19}$ If one wants to understand a

\footnotetext{
${ }^{13}$ Roger Smith, Property Law (8 $8^{\text {th }}$ edn, Pearson 2014) 494-95.

14 ibid. See also, Hunter v Canary Wharf [1997] AC 665.

15 National Provincial Bank v Ainsworth [1965] AC 1175, 1247-48 (HL).

${ }^{16}$ Peter Birks, 'Before we begin: Five keys to Land Law' in Susan Bright \& James Dewar (eds), Land Law Themes and Perspectives (OUP 1998) 482.

${ }^{17}$ Kevin Gray and Susan Francis Gray, Elements of Land Law (5 $5^{\text {th }}$ edn, OUP 2009) para 1.7.12.

${ }^{18}$ Law of Property Act, 1925, s 1(2)-(3).

19 Smith (n 13) 479.
} 
licence not for what it is not, but for what it is, then the residual approach is not helpful.

Thus, land law has its own reasons for regarding licences as non-proprietary. For copyright law to rely on the same principles does not make sense, if similar reasons do not exist. The following section explores copyright law on licences.

\subsection{Copyright Law on Licences}

Historically, copyright law has understood the concept of licences along the same lines as land law. The impact of Thomas was seen in patent cases first, ${ }^{20}$ and then in copyright cases, ${ }^{21}$ in holding that the grant a of licence could not pass any property interest. Some cases went further to state that a licence must be devoid of property interest in order to distinguish it from an assignment. ${ }^{22}$ The case law also emphasised that since a licence did not pass a property interest, the licensee cannot sue in her own right, ${ }^{23}$ and any assignee who took from the copyright owner was not bound by the licence, regardless of whether the assignee had notice of the licence. ${ }^{24}$ Thus, courts applied the residuary conception of a licence also to copyright licences in holding that a licence is that which is not an assignment. Assignment, which is parting irreversibly with the property, ${ }^{25}$ was seen as being different from granting a licence which could be terminated. To draw this distinction more clearly, courts regarded the existence of property interest as crucial.

\footnotetext{
${ }^{20}$ Heap v Hartley (1889) 42 Ch D 461, 468-69.

${ }^{21}$ London Printing and Publishing Alliance (Ltd) v Cox [1891] 3 Ch 291, 297, where the principles in Heap were held to be equally applicable to copyright cases. The relevant statute was Fine Arts Copyright Act, 1862, s 3.

22 ibid. On appeal the decision was reversed on other grounds.

${ }^{23}$ Heap (n 20) 469; Nelson v Horniman (1909) 26 TLR 188.

${ }^{24}$ London Printing (n 21).

${ }^{25}$ Conceptually, I regard an assignment as parting with the ownership rights with no reversionary interests with the copyright owner. A time bound assignment within this rubric will be regarded as an exclusive licence.
} 
Subsequently, s 5(2), Copyright Act, 1911, referred to a copyright licence as an interest in copyright. If the opportunity had arisen, courts may have been willing to regard copyright licences as a licence coupled with grant, as opposed to a mere licence without any property interest. ${ }^{26}$ However, s 36(4), Copyright Act, 1956 consolidated this position that a licence granted by a copyright owner is binding on every successor in title to his interest in copyright, except a purchaser (or a person deriving title from such a purchaser) in good faith for valuable consideration without notice (actual or constructive) of the licence. Such notice is required in land law normally when a purchaser of a legal interest is sought to be bound by a pre-existing equitable property interest. ${ }^{27}$ Although it is unclear why a copyright licence would be an equitable interest, it begs the question whether copyright licences are a property interest.

The current statute, the CDPA, does not define a licence, ${ }^{28}$ but provides that an infringement is the doing of a restricted act 'without the licence of the copyright owner'. ${ }^{29}$ However, protecting a person from infringement is not its only role, as the binding nature of a licence is carried over also to the CDPA. ${ }^{30}$ In addition, exclusive licensees have the same rights against successors in title as the grantors of their licence. ${ }^{31}$ An exclusive licensee has, except against the copyright owner, the same rights and remedies in respect of matters occurring after the grant of the licence as if the licence had been an assignment. Her rights and

\footnotetext{
${ }^{26}$ British Actors Film Co Ltd v Glover [1918] 1KB 299, 307-08. The court held that the grant was a partial assignment, and therefore, did not explore whether a licence was a property interest. ibid 309.

${ }_{27}$ Port Line Ltd v Ben Line Ltd [1958] 2 QB 146, 167-68.

${ }^{28} \mathrm{CDPA}$, s 116(3) states that a copyright licence means a licence to do, or authorise the doing of, any of the acts restricted by copyright. This does not define a licence as such, and this provision only applies to the specific section on copyright licensing schemes.

${ }^{29}$ CDPA, ss 16(2) and 22, 23, 24 (emphasis added). Other common law countries use the same expression. See ACA, ss 36(1), 37(1) and 38(1), and 101(1), 102(1) and 103(1); SCO, ss 31(1), 32, 33, and 103(1), 104(1) and 105(1); HKCO, ss 22(2), 30, 31(1), 32(1).

${ }^{30}$ Copyright Act, 1956, s 36(4); CDPA, s 90(4). See also, ACA, s 196(4); SCA, s 194(4); HKCO, s 101(4).

${ }^{31}$ CDPA, s 92(2). See also, HKCO, s 103(2).
} 
remedies are concurrent with those of the copyright owner. ${ }^{32}$ An exclusive licensee can obtain a preliminary injunction in an action for infringement in respect of which she has concurrent right of action, without joining the copyright owner; but she must join the copyright owner for any final orders. ${ }^{33}$ While an exclusive licence must be in writing and signed by or on behalf of the copyright owner, ${ }^{34}$ no writing is required to create a non-exclusive licence. A nonexclusive licensee can sue in her own name if authorised to do so by the copyright owner in writing, but must join the copyright owner in the action as a co-claimant or as a co-defendant. ${ }^{35}$ These provisions do seem to undermine the reasons noted above as to the importance of distinguishing between a licence and an assignment.

Modern commentators still insist that neither non-exclusive licences nor exclusive licences are interests in property, ${ }^{36}$ and that the rights that the licensees have are only statutory. ${ }^{37}$ In a similar vein, in CBS United Kingdom Ltd v Charmdale Record Distributors Ltd, Brown-Wilkinson J described the right of an exclusive licensee to sue as 'purely procedural'. ${ }^{38}$ He insisted that despite the provision binding successors in title, the distinction between a licensee and assignee is still maintained in the copyright legislation. ${ }^{39}$ Even if a distinction must

\footnotetext{
32 Copyright Act, 1956, s 19; CDPA, s 101(1) and (2). See also, ACA, ss 119; SCA, s 123; HKCO, ss 112.

${ }^{33}$ CDPA, 102. See also ACA, s 120; SCA, s 124; HKCO, s 113.

${ }^{34}$ CDPA, s 92(1). See also, ACA, s 10(1); HKCO, s 103(1).

${ }^{35}$ CDPA, s 101A(1)-(5). See generally, Gillian Davies, Nicholas Caddick and Gwilym Harbottle, Copinger and Skone James on Copyright (17th edn, Sweet \& Maxwell 2016) paras [5-219]-[5-223]. There is no corresponding provision in Australia, Singapore and Hong Kong.

${ }^{36}$ Davies, Caddick and Harbottle (n 35) para 5-204; Lionel Bently and Brad Sherman, Intellectual Property Law (4th edn, OUP 2014) 295-96; Mary Vitoria, et al, Laddie, Prescott and Vitoria The Modern Law of Copyright and Designs (4th edn, vol 1, Lexis Nexis 2011) para [25.2].

${ }^{37}$ Davies, Caddick and Harbottle (n 35) para [5-213].

38 [1981] 1 Ch 91, 98. This decision dealt with the Copyright Act, 1956, ss 19 and 36(4).

39 ibid.
} 
be maintained between an assignment and a licence, it is not clear why the existence of property interest alone is the distinguishing factor.

If the reason for insisting that a copyright licence is not a property interest is to maintain the residuary nature of licences akin to land law, then it does not sit comfortably with the CDPA provisions. Although the CDPA does not provide for a list of property interests in copyright akin to those in land, the policy reasons behind numerus clausus, such as preventing a property owner from burdening a third party with unknown or undiscoverable interests, ${ }^{40}$ apply equally to copyright. ${ }^{41}$ However, even if numerus clausus must be respected in copyright, nothing stops a statutory recognition of a new property interest. In this vein, it is debatable whether a statutory provision binding successors in title alone is sufficient to regard a licence as a property interest. ${ }^{42}$

Regardless of whether copyright licences can be regarded a property interest, a provision making licences bind successors in title requires that licences be definable, identifiable and capable of being assumed by the successors in title. ${ }^{43}$ Further, the successors in title are bound not only if they have actual notice of the licences, but also constructive notice. Therefore, it is arguable that a successor in title can be fixed with the constructive notice of even an implied licence if she could have discovered it through reasonable care and inspection, ${ }^{44}$ though this question has not faced judicial scrutiny. In summary, these arguments

\footnotetext{
40 Keppell v Bailey (1834) 2 My \& K 517.

${ }^{41}$ But cf, Christina Mulligan, 'A Numerus Clausus Principle for Intellectual Property' [2013] 80 Tennessee L Rev 235.

${ }^{42}$ Bare copyright licences discussed in Chapter III below may not satisfy the need for stability and a degree of permanence, as required by Ainsworth (n 15).

${ }^{43}$ Ainsworth (n 15).

${ }^{44}$ For a discussion on constructive notice in land law, see Gray and Gray (n 17) para 8.3.25.
} 
cast doubts on the earlier understanding of the courts, making it all the more important that copyright licences are conceptualised not as a residual category, but as a category of their own. An independent conceptualisation of a licence can thus help differentiate between a licence and an assignment, and not rely only on the existence of property interest. ${ }^{45}$

The CDPA has achieved something remarkable concerning non-exclusive licences to recognise these as binding on the successors in title, without burdening them with the formality requirements that normally go with the creation of a property interest. Being exempt from formal requirements, non-exclusive licences enjoy a level flexibility in the manner in which they arise. Non-exclusive licences are now more durable because of their ability to withstand the assignment of copyright. Given the heightened importance of non-exclusive licences, especially to accommodate the uses of copyright works on the internet, such durability and flexibility can be a welcome strength.

However, although the CDPA acknowledges the significance of non-exclusive licences in copyright law, it provides no clue as to the constituents of a licence. This may explain why courts blindly replicate land law. This has inhibited the development of an autonomous jurisprudence exploring the nature and the constituents of a copyright licence. Since neither land law, nor copyright law sufficiently advert to the nature and constituents of a licence, we must look to analytical jurisprudence for assistance.

\subsection{Analytical Jurisprudence on Licences}

In copyright law, the statutory provisions noted above have bestowed on licences some attributes of a property interest. In land law, the general rule is that a licence is not a property interest. Whilst land law has its own reasons why it does not recognise property interest in

\footnotetext{
45 The importance of distinguishing between non-exclusive licences, exclusive licences and assignments is underscored in relation to consent-based implied contractual licences. See Chapter IV, section 2.1.1.1 below.
} 
licences, copyright case law has unfortunately not seen the difference in the copyright context, and has failed to develop its own jurisprudence in relation to copyright licences. The result is a vacuum regarding the constituents and characteristics of a licence.

To fill this gap, we can take a step back and turn to analytical jurisprudence, so that we can elucidate the legal concept of licence itself, independent of the debate over whether a licence is a property interest. ${ }^{46}$ Analytical jurisprudence may help us find the constituents of a licence. These constituents should distil a licence to such an extent that these should be identifiable even amidst the diversity of factual matrix that licences present. Hohfeld made one of the best efforts to analyse a licence to reveal its constituents. ${ }^{47}$ Hohfeldian analysis not only helps us identify the constituents of a licence, but also in explaining certain fundamental characteristics of a licence.

\subsubsection{Hohfeldian analytics}

Hohfeld's concern in his seminal work was to clarify the most basic legal conceptions ordinarily used in judicial reasoning, and to urge a more careful and conscious use of these conceptions. ${ }^{48}$ To begin with, Hohfeld spoke of eight fundamental legal conceptions (FLCs), which can be arranged as four jural correlatives between themselves, namely right-duty, privilege-no right, power-liability and immunity-disability. ${ }^{49}$ If one person has a right, it creates

\footnotetext{
${ }^{46}$ Analytical jurisprudence is described as 'the branch of legal theory or philosophy that is concerned with the linguistic and logical elucidation of legal concepts.' Nicholas Bunnin and Jiyan Yu (eds), The Blackwell Dictionary of Western Philosophy (Blackwell Publishing 2004).

${ }^{47}$ Many scholars have applied Hohfeldian framework to licences in various contexts. See Albert J Harno, 'The Revocability of Licences as Applied to Property in Land' [1919] 7 Ky LJ 1, 2; Charles Clark, 'Licences in Real Property Law' [1921] 21 Colum L Rev 757; Ben McFarlane, Nicholas Hopkins and Sarah Nield, Land Law Text, Cases and Materials (3rd edn, OUP 2015) 698-99; Christopher Newman, 'A License Is Not a "Contract Not To Sue”: Disentangling Property and Contract in the Law of Copyright Licenses' [2013] Iowa L Rev 1101, 1108.

48 Wesley Newcomb Hohfeld, 'Some Fundamental Legal Conceptions as applied in Judicial Reasoning' [1913-14] 23 Yale LJ 16, 20 (Hohfeld 1).

49 ibid 30.
} 
a corresponding duty in another person as its jural correlative; and, if one person has a privilege, it creates a corresponding no-right in another person. And so on for other correlatives. ${ }^{50}$

To Hohfeld, a licence is 'a generic term to indicate a group of operative facts required to create a particular privilege, ${ }^{51}$ Where a privilege is created in one person, there is a corresponding no-right created in someone else. Therefore, in the Hohfeldian conception of a licence, one must understand the following three aspects - privilege, no-right and operative facts. This conception is seemingly quite broad. Although Hohfeld does give the example of 'leave and licence' used in land law, ${ }^{52}$ Hohfeld understands operative facts much more broadly, as I explain below.

\subsubsection{Privilege}

The FLC present in a licence is privilege. Hohfeld does not define what he means by privilege, but conceptualises it as the negative of duty. He gives a range of circumstances where privilege could arise - such as privileged communications and the privilege against self-incrimination. ${ }^{53}$ For Hohfeld, another way of understanding privilege is to think of it as liberty, which again captures the state of being free of owing any duty. ${ }^{54}$

In the context of property, if $\mathrm{P}$ has the title to a certain land with a house and a garden, all members of the public have a duty not to enter P's land. However, if $\mathrm{P}$ grants a licence to a member of the public Q, to enter her garden for a garden party, Q's duty otherwise not to

\footnotetext{
50 ibid 31-32.

51 ibid 44.

52 ibid.

53 ibid 39.

54 ibid 36.
} 
enter P's property is transformed into a privilege to enter the property. ${ }^{55}$ Similarly, when copyright arises in a novel A has authored, all members of the public have a duty not to make copies of the novel. If A consents to a member of the public B copying the novel, then B's duty not to interfere with A's copyright is transformed into a privilege to make copies.

\subsubsection{No-right}

The jural correlative of a privilege or liberty is 'no-right' in the person granting the privilege. ${ }^{56}$ Hohfeld does admit that this is perhaps an unhappy expression, and that there is really 'no single term available' to express this FLC. ${ }^{57}$ Where a person would otherwise have had a right to prevent a particular action, when such person creates a privilege, the right she originally had turns into a 'no-right'.

In the example above, if $\mathrm{P}$, the title holder of the house, invites $\mathrm{Q}$ for the garden party, P has 'no-right' to stop Q from entering the land, so long as $\mathrm{P}$ allows the licence to continue. P's right to prevent Q from entering her land has been replaced by a no-right that $\mathrm{P}$ can prevent Q from entering her land. Similarly, in the copyright example above, once A, the copyright owner, consents to B copying the book, A has 'no-right' to stop B from making copies of A's book, so long as the licence continues.

\subsubsection{Operative facts}

For Hohfeld, operative facts 'are those which (...) suffice to change legal relations, that is, either to create a new relation, or to extinguish an old one, or to perform both of these

\footnotetext{
55 A similar example can be seen in Wesley Newcomb Hohfeld, 'Fundamental Legal Conceptions as applied in Judicial Reasoning' [1916-17] 26 Yale LJ 710, 743 (Hohfeld 2), where he refers to the grant of a privilege as extinguishing the duty of non-interference.

${ }^{56}$ Hohfeld 1 (n 48) 32-33.

57 ibid 33.
} 
functions simultaneously. ${ }^{58}$ In a licence in relation to property, one is looking for the operative facts that change the jural relation of duty-right in relation to property, to privilege-no right. ${ }^{59}$ Hohfeld further says that 'of all the facts to be ascertained by the tribunal, the operative are (...) of primary importance. ${ }^{60}$

In the examples above, the facts that lead to $\mathrm{P}$, the landowner, granting $\mathrm{Q}$ the privilege to enter P's land (in place of Q having a duty not to enter), are what Hohfeld calls the operative facts. These facts could be the existence of a letter of invitation, or a phone call or indeed, any conduct that indicates P's consent. Similarly, in the copyright example, P's granting to Q a privilege to copy her novel could be evidenced by a document to that effect or by P's conduct, either of which would be operative facts.

Hohfeld lamented that much of the difficulty in understanding the concept of licence could be eliminated if we confine the term licence only to those operative facts which lead to privilege. Instead, he says that the term licence is unhelpfully used in practice by courts and commentators to cover not only more complex groups of operative facts, but also the other jural relations flowing from such complex facts. ${ }^{61}$

\subsubsection{Benefits of Hohfeldian conception}

The benefits of adopting Hohfeldian conception of a licence are explained below.

\footnotetext{
58 ibid 25. Hohfeld distinguishes an operative fact from an evidential fact, 'which, on being ascertained, affords some logical basis - not conclusive - for inferring some other fact.' ibid 27.

${ }^{59}$ There can also be other forms of licences, such as the licence granted in Thomas, which was to permit a particular activity - a privilege in Sorrell to sell the wine, and Thomas having no-right to stop it, due to the operative facts that established the existence of a permission from the Crown.

${ }^{60}$ Hohfeld 1 (n 48) 27.

${ }^{61}$ Wesley Newcomb Hohfeld, 'Faulty Analysis in Easement and Licence Cases' [1917] 27 Yale LJ 66, 92, at note 49 (Hohfeld 3).
} 


\subsubsection{Licence as a group of facts}

Hohfeld regards a licence as a 'group of facts' required to create a privilege. In other words, to ascertain the existence of a licence, a court must find the group of facts of a particular description. This conception is particularly beneficial in implying a copyright licence, since implication is an ex post assessment of the facts and circumstances by a court, to ascertain whether a certain use is covered by an implied licence or amounts to infringement. A court must have some guidance to navigate through such facts and circumstances, and find those that support a licence. Applying the land law conception that a licence belongs to a residual category, provides no guidance as to what these relevant facts might be. Conceptualising a licence itself as a group of facts of a particular description, therefore, guides the court to look for facts of that description, namely those that give rise to a privilege-no right relation.

Conceptualising a licence as a group of facts of a particular description is also Hohfeld's way of distilling a licence to the bare minimum. This provides flexibility to accommodate the diverse facts and circumstances a licence presents. So long as the facts meet the relevant description (namely those that create privilege), a court will be required to take them into account. This also helps in identifying the relevant facts leading to a licence amidst other facts which may give rise to other jural relations.

\subsubsection{Licence not in itself a contract}

By identifying privilege-no right as the only jural relation in a licence, and by confining the enquiry to only those facts that lead to privilege-no right relation, Hohfeld distinguishes licences from other legal concepts, including a contract. This helps to establish that a licence is not in itself a contract. Some scholars, especially in the US, suggest that a licence is itself ' $a$ 
contract not to sue'. ${ }^{62}$ Supporters of this idea argue that the grant of licence itself gives the licensee the right to use the property, and places a duty on the licensor not to sue the licensee.

If one were to consider it from a Hohfeldian perspective, it is difficult to see how the licensee has a right to use, as opposed to a privilege, as there is no corresponding duty on the licensor to let the licensee use the property. The licensor as the property owner has no duty to let anyone use the property, but has a power to let someone use her property if she so wishes. Further, the grant of a privilege itself is sufficient to permit an act and prevent a trespass, since the licensor takes on a no-right to sue the licensee. A right not to be sued would be superfluous, since there will be no corresponding duty on the licensor not to sue. ${ }^{63}$

\subsubsection{Licence as a legal relationship and bare licences}

To Hohfeld, a legal relationship is a complex set of operative facts, giving rise to different FLCs and corresponding jural relations. Thus, conceptualising a licence only as facts does not deprive it of the ability to be a legal relationship. Hohfeld's protest is against regarding ass a licence a legal relationship that includes a more complex set of operative facts than those that lead to a privilege. The existence of the relevant operative facts, therefore, reveals the existence of a licence, but says nothing about the overall legal relationship within which it exists, if the legal relationship has a combination of other jural relations. If, the operative facts point to certain rights and duties in addition to those leading to privilege and no-right, then the resulting legal relationship as a whole should not be called a licence under Hohfeld's scheme, although a licence is incorporated within such legal relationship.

\footnotetext{
${ }^{62}$ See Newman (n 47) for a more detailed discussion; see also Bently and Sherman (n 36) 296, where the authors opine that 'a bare licensee acquires the right not to be sued in relation to the acts set out in the licence...'.

${ }^{63}$ Newman (n 47) 1130. Superfluity also goes against Hohfeldian approach which demands precision in the use of legal language. Hohfeld 1 (n 48) 20.
} 
For example, suppose $\mathrm{P}$ is an antique collector who holds an exhibition open to public on her land, but charges a certain entrance fee. Once a member of the public Q pays the entrance fee, $\mathrm{P}$ has a duty to let $\mathrm{Q}$ in, and $\mathrm{Q}$ has a corresponding right to enter the land. There is an act of permission here, which would have given rise to a licence. But there are also other operative facts which should give rise to different FLCs and jural relations. One such is that the permission is in exchange for money, which gives rise to a right and a duty as stated above. If one calls this more encompassing relationship a licence, she will be mistakenly coming to the conclusion that a licence must also give rise to rights and duties. In the same example, instead of selling tickets, if $\mathrm{P}$ invites a friend $\mathrm{Q}$, to come to her land to take a look at the collection, then P has granted Q a permission to enter her land, but neither of them has rights or duties over each other. There are no operative facts that warrant the existence of rights or duties, such as exchange of consideration. Even though this is a licence, one might make the mistake of not regarding it so, if one believes that a licence must create rights and duties.

It is possible, however, that the only jural relation in a legal relationship is that of privilege-no right, as in the case where P invites Q to a garden party at P's land. The underlying operative facts in the legal relationship only point to a licence. A legal relationship is normally a complex set of jural relations, but in this case only privilege-no right relationship exists. In this case, both the operative facts that point to a licence and the overall legal relationship are the same. To distinguish the legal relationship from the underlying operative facts, we refer to this legal relationship as a 'bare licence', or a 'mere licence' as a Hohfeldian would call it. ${ }^{64}$

\subsubsection{Licence within a contract}

A licence, though not a contract in itself, can arise within a contractual context. A contract

\footnotetext{
${ }^{64}$ Clark (n 47) 762. Hohfeld also regards licences as a property interest. Hohfeld 3 (n 61) 95-96. However, as explained in Chapter I above, to establish a licence as a property interest is not the focus of this thesis.
} 
differs from a bare licence also in the way it is formed. Courts and commentators generally agree that English law requires the following for the formation of a contract: ${ }^{65}$

- offer, which is an expression of what each party to the agreement must do or refrain from doing and the willingness of the offeror to be bound; ${ }^{66}$

- acceptance, which is an expression of willingness to contract on exact terms of the offer; ${ }^{67}$

- intention to create legal relations; ${ }^{68}$

- arrangement supported by consideration $;^{69}$ and

- fulfilling the formalities, if any.

Consideration is one of the most controversial requirements of contract formation. A detailed discussion on the normative justification of consideration is beyond the scope of this thesis. It suffices to say that an exchange is essential for a contract to come into existence, even if the requirement of consideration appears superfluous in certain contracts. ${ }^{70}$

The purpose of contract law is 'to secure cooperation in human behaviour, and particularly in exchange. ${ }^{71}$ The social relevance of property means that property in its entirety, or a privilege in relation to property, may be used in exchange for something else the property

\footnotetext{
${ }^{65}$ Patrick Atiyah and Stephen Smith, Atiyah's Introduction to the Law of Contract (6 $6^{\text {th }}$ edn, Clarendon Press 2005) 93; Jack Beatson, Andrew Burrows and John Cartwright, Anson's Law of Contract (30 th edn, OUP 2016) $31 \mathrm{ff}$.

${ }^{66}$ Atiyah and Smith (n 65) 36-40.

67 ibid 50.

68 ibid 98-106.

69 ibid 106-130.

${ }^{70}$ For example, unilateral agreements, which are in the form of say a reward for finding a lost article. See Beatson, Burrows and Cartwright (n 65) 48.

71 Atiyah and Smith (n 65) 6.
} 
owner values. Thus, a contract may be employed to sell all rights to a property or to licence the use of the property. In both cases, consideration of some form flows from the person with whom the contract is made, in exchange for the property or a licence from the property owner. $^{72}$ In the example above of P's antique collection, P's objective is to earn money from letting people see her collection. Therefore, she exchanges a licence to enter her land in consideration for payment for an entrance ticket. Where consideration flows in return for a licence, we refer to it as a contractual licence. A contractual licence incorporates a licence, and has elements of both a contract and a licence. ${ }^{73}$

\subsubsection{Limitations of Hohfeldian conception}

The breadth of the Hohfeldian conception of a licence is both its strength and its limitation. Operative facts hold the key to how a licence arises. While the conception is flexible enough to accommodate different facts giving rise to licences, Hohfeld does not tell us how one may find these facts. All we know is that the operative facts must create a privilege and no-right relation, which is too broad and general for our purposes. Interestingly, Hohfeld also describes a licence as a 'group of operative facts which constitute a "mere permission" to do (...) a given thing..$^{74}$ Thus, Hohfeld uses 'licence' and 'permission' interchangeably, as they are both made up of operative facts. What are these operative facts then?

Hohfeldian analysis itself might hold a clue. Hohfeld conceptualises 'power' as an FLC that can bring about a change in the jural relation. ${ }^{75}$ For example $\mathrm{P}$, a police officer exercising her power of arrest deprives the arrested person her right to roam freely. As we saw above,

\footnotetext{
${ }^{72}$ Newman (n 47) 1103.

${ }^{73}$ See generally, Chapter IV.

${ }^{74}$ Hohfeld 3 (n 61) 92, note 49.

${ }^{75}$ Hohfeld 1 (n 48) 44-45.
} 
since a licence is created by the change in jural relations from right-duty to privilege-no right, such change must have been brought about by the exercise of a power. The operative facts therefore, describe the exercise of such power. Thus, the clue to finding the operative facts lies in finding the sources of power capable of changing the jural relation from right-duty to privilege-no right.

To identify the sources of power for a copyright licence to arise, one must contextualise the discussion to copyright law. This brings us to the section below.

\section{Copyright Law and Express Copyright Licences}

The effort in section 1 was to identify the constituents of a licence. Neither land law, nor copyright law, but Hohfeldian analytics shed light on the constituents of a licence. To Hohfeld a licence is a group of operative facts that create a privilege-no right relation. While Hohfeld does explain a privilege-no right relation to some extent, his conception of operative facts is too broad and general for our purposes. As explained above, since the operative facts describe the exercise of a power, to ascertain these sources of powers for copyright licences, one must delve into the copyright context.

This section identifies the sources of power for an express copyright licence to arise, because the operative facts leading to these licences are more readily ascertainable. These sources help channel these operative facts into categories, bringing some order into the otherwise broad conception of operative facts. These sources matter also because certain consequences follow (namely, the revocability of a licence) depending on the source that gives rise to a copyright licence. As section 3 below will demonstrate, the same sources of power are invoked also for implying copyright licences.

\subsection{Sources of Power}

The CDPA says that it is an infringement for a person to engage in a restrictive act without 
the licence 'of the copyright owner'. This means that consent of the copyright owner can give rise to a licence. As a matter of general commercial law, a custom may also act as a source to grant a licence. Therefore, a licence 'of the copyright owner' can arise also from the community of which the copyright owner is a member, consenting on her behalf in the form of a custom. The CDPA also empowers the state to grant a compulsory licence in furtherance of public policy. Each of these sources is discussed below.

\subsubsection{Ownership power to consent}

It may appear intuitive for a 'licence of the copyright owner' to be granted with the consent of the copyright owner. But what is the source of power of the copyright owner to consent? Property theory offers a credible explanation, since the ability to consent arises from the powers of ownership, as explained below.

For some scholars, the essential attributes of ownership are that (a) it confers a 'right to exclude', ${ }^{76}$ and (b) it is alienable. ${ }^{77}$ The theories that highlight excludability and alienability help delineate property from non-property. However, these theories alone do not adequately describe property, since the right to exclude or to alienate do not account for the ability of the property owner to use or authorise the use of the property, short of complete transfer of ownership. ${ }^{78}$ One must be able to establish the powers of the owner beyond exclusion and alienation, to ascertain whether she can also consent to someone else using her property.

In his discussion on the powers of ownership, or what he calls the incidents of

\footnotetext{
76 Thomas Merrill, 'Property and the Right to Exclude' (1998) 77 Neb LRev 730.

${ }^{77}$ Michael Bridge, Personal Property Law (OUP 2015) 2.

${ }^{78}$ For a similar argument, see Newman (n 47) 1114.
} 
ownership', Honoré includes the right to use and the right to manage, among others. ${ }^{79}$ While Honore conceived of the 'use' in the right to use as 'the owner's personal use and enjoyment of the thing owned', he understood the right to manage as: ${ }^{80}$

the right to decide how and by whom the thing owned shall be used. This right depends, legally, on a cluster of powers, chiefly powers of licensing acts which would otherwise be unlawful and powers of contracting: the power to admit others to one's land, to permit others to use one's things, to define the limit of such permission, and to contract effectively in regard to the use (in the literal sense) and exploitation of the thing owned.

Whether Honoré's incidents of ownership can be regarded as a complete enumeration of property rights is beyond the scope of this thesis. But Honoré's is one of the authoritative works that provide a possible list of rights that a property owner may be able to exercise. ${ }^{81}$

Therefore, the property owner does have powers beyond excludability and alienability, and this includes using the property. An incident of using the property is to authorise the use of the property, by voluntarily consenting to its use by another person, at the property owner's discretion. Such consent is, therefore, the exercise of ownership powers to grant a licence.

Can a copyright owner's consent therefore, bring a copyright licence into existence? To answer this, one must first establish copyright as property. Some scholars have been sceptical about regarding copyright as property. The lack of tangibility of copyright, ${ }^{82}$ and the resulting inability of copyright to be the subject of conversion, ${ }^{83}$ are among the reasons cited.

\footnotetext{
79 A M Honoré, 'Ownership' in Anthony Gordon Guest (ed), Oxford Essays in Jurisprudence (Clarendon Press 1961) 107, 112-24.

80 ibid 116.

${ }^{81}$ Honoré did not however, regard the absence of one of the incidents as necessarily precluding the existence of property. ibid 124-28.

82 Ben McFarlane, The Structure of Property Law (Hart Publishing 2008) 132-34.

${ }^{83}$ Simon Douglas, 'Kuwait Airways Corporation v Iraqi Airways Company' in Simon Douglas, Robin Hickey and Emma Waring (eds) Landmark Cases in Property Law (Hart Publishing, 2013) 212-13.
} 
The CDPA states unequivocally that copyright is a property right. ${ }^{84}$ Copyright grants exclusive rights ${ }^{85}$ to copyright owner in the copyright work, ${ }^{86}$ and enables her to alienate it. ${ }^{87}$ Therefore, the theories that define property based on excludability and alienability described above should apply similarly to copyright. ${ }^{88}$

For those who believe tangibility is the crux of property, the now prevailing notion is that property refers to the rights 'between persons' in relation to a thing, and not to the 'thing' itself. The 'things' thus become the object of property, rather than property itself. ${ }^{89}$ Therefore, the tangibility or intangibility of the underlying object of property should not matter, so long as a structure of rights between persons can be built in relation to the object of property. This is the notion of 'dematerialised property', which Rahmatian has developed. ${ }^{90}$ It describes why and how the structure of rights granted by the copyright system over copyright as the object of property has the defining characteristics of property. ${ }^{91}$

Regarding the issue of inability of copyright to be 'converted', commentators now acknowledge that this in itself is not determinative of whether a subject matter is property, as a subject matter can serve as property for some purposes and not for others. ${ }^{92}$ Indeed they

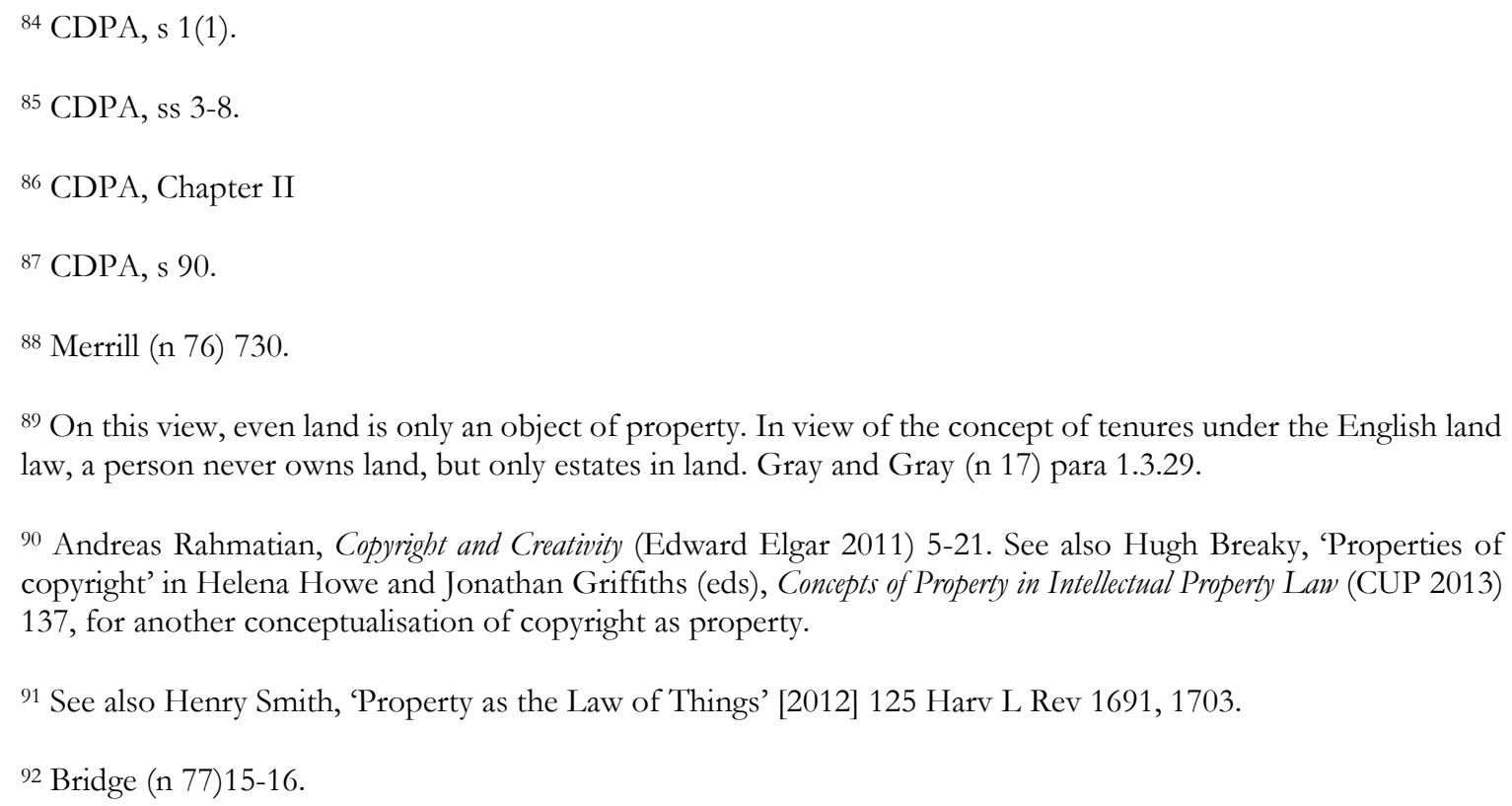


regard the distinction of choses in possession (those that can be possessed, and therefore, converted, namely tangibles) and choses in action (which can only be obtained through a court action - such as recovery of a debt) as gradually decreasing in importance. Instead, they regard intangible property, i.e., all that remains of personal property after tangibles are removed, as a better classification of personal property. Thus, the spectrum of personal property is broad enough to accommodate copyright, ${ }^{93}$ and therefore, property is no longer only that which can be converted.

A copyright owner therefore has the power to consent to the use of copyright work, and grant a licence based on consent.

\subsubsection{Custom}

Historically, a custom referred to a particular rule which had existed from 'time immemorial' in a particular locality, and governed like the local law, even if inconsistent with the general common law of the realm. ${ }^{94} \mathrm{~A}$ usage on the other hand was a particular course of dealing or conduct generally adopted by persons engaged in a particular trade, business or profession, which is so notorious that persons operating within such trade, business or profession are taken to have intended to follow it. ${ }^{95}$ The significance of a custom in the historical or classical sense is receding. ${ }^{96}$ Only usages are relevant in this thesis. Most commentators use the terms

\footnotetext{
93 ibid 10-16.

${ }^{94}$ Halsbury's Laws (2012) vol 32, para 5.

95 ibid, paras 50-51.

${ }_{96} \mathrm{ibid}$, paras 1, 41, 45. Examples include manorial customs, ecclesiastical customs and the like, which have now been abolished by Law of Property Act, 1925.
} 
customs and usages interchangeably, ${ }^{97}$ although technically, the reference is made only to usages. These terms are used interchangeably also in this thesis.

A custom refers to the 'repeated voluntary interactions among parties from the relevant groups,.$^{98}$ Customs are created and maintained with 'the general approval and approbation of all the parties within the group. ${ }^{99}$ Whilst consent discussed in section 2.1.1 above embodies consent of one person, namely the copyright owner, a custom embodies the consent of a community. This is because, the community of which the copyright owner is a part consents to the formation and maintenance of the custom by repeatedly engaging in it. ${ }^{100}$ Therefore, it is essential for the community to be representative of the copyright owner, to consent on his behalf. ${ }^{101}$ For example, a journalist operating within the newspaper industry is taken to have intended to follow the customs in that industry, since customs are formed and maintained within the newspaper industry with the collective consent of its members, such as the journalists.

A custom's power to bind actors within a trade, business or profession comes with the members engaging in the custom voluntarily, repeatedly, consistently and universally. Thus, a custom does not require a court ruling for its establishment, although its subsistence can be challenged or confirmed in a court. ${ }^{102}$ Once established, a custom has the power to regulate

\footnotetext{
${ }^{97}$ Gerard McMeel, The Construction of Contracts: Interpretation, Implication, and Rectification (2nd edn, OUP 2011) para 12.02 .

98 Richard Epstein, 'Some Reflections on Custom in the IP Universe' [2007] 93 Va L Rev Brief 223, 224.

${ }^{99}$ Richard Epstein, 'International News Service v Associated Press: Custom and Law as Sources of Property Rights in News' [1992] 78 Va L Rev 85, 86, 88.

100 Jennifer Rothman, 'Copyright, Custom and Lessons from the Common Law' in Shyamakrishna Balganesh (ed), Intellectual Property and Common Law (CUP 2013) 243.

101 Jennifer Rothman, ‘The Questionable Use of Custom in Intellectual Property’ [2007] 93 Va L Rev 1899, 1974.

102 Cunliffe-Owen v Teacher and Greenwood [1967] 1 WLR 1421, 1438.
} 
the conduct of the members of the trade, business or profession to which it relates, thereby changing their jural relations.

Such change of jural relations can also be from right-duty in relation to property, such as copyright, to privilege-no right. It is conceivable for certain practices permitting certain uses of copyright works to have become customs. Commentators speak of many industry specific customs that form the basis of a copyright licence, ${ }^{103}$ confirming customs as a source of power from which these copyright licences arise.

If a practice has not yet become recognised as binding, it will remain a trade practice. In Hohfeldian terms, if the operative facts only establish a trade practice, they would be insufficient to change the jural relations from right-duty to privilege-no right. However, trade practices can provide evidence as to the background in which a contract is to be performed. ${ }^{104}$

\subsubsection{State intervention for public policy reasons}

The words without the licence 'of the copyright owner' in the CDPA do not necessarily mean that the licence can only emanate from the consent of the copyright owner. Even though property theory recognises that copyright owner has power to do as she pleases with her copyright, such power is not absolute. Harris argues that the ownership of property is subject to 'property-limitation rules', which he describes as those that prima facie subtract ownership powers and privileges. ${ }^{105} \mathrm{He}$ argues that these rules pre-suppose that certain property interests must be restricted or reallocated. Although the examples he gives are more in the nature of

\footnotetext{
${ }^{103}$ Davies, Caddick and Harbottle (n 35) para 5-225; see also Vitoria, et al (n 36) para 25.15 for examples.

104 Richard Austen-Baker, Implied Terms in English Contract Law (Edward Elgar 2011) para [5.01].

105 JW Harris, Property and Justice (OUP 2002) 90.
} 
rules on nuisance, ${ }^{106}$ this idea could apply more broadly to incorporate situations where the state can intervene with the use of property for policy reasons. The CDPA empowers the state to compel a copyright owner to grant a licence for public policy reasons.

One of the objectives of copyright legislation is to balance the competing interests of different stakeholders, including those of the copyright owner and the users of copyright content. ${ }^{107}$ In certain circumstances, to strike this balance the law intervenes to compel a copyright owner to issue a licence. Examples include compulsory licences, where a statute compels a copyright owner to grant a license to enable a particular use of the work for a fee, and statutory licences where a statute not only compels a copyright owner to grant a licence, but fixes the licence fee. ${ }^{108}$ This is still a licence because it grants a privilege to the user, while the copyright owner has no-right to challenge such use.

The specific instances where compulsory licenses could be issued include those that the Secretary of State may order in relation to lending of works, ${ }^{109}$ and licences that the competition authority may order in exercise of its powers, ${ }^{110}$ to mention a few. ${ }^{111}$ The policy considerations underlying these provisions include making a work available or available on reasonable terms or discouraging anti-competitive behaviour. Short of granting a compulsory licence, the CDPA also has many instances where it interferes with the licensing of exclusive rights in public interest, such as in requiring compulsory collective management for certain

106 ibid 5, 90-91.

107 See recital 31, Infosoc Directive.

${ }^{108}$ Davies, Caddick and Harbottle (n 35) para 28-02.

${ }^{109}$ CDPA, s 66.

110 CDPA, s 144.

${ }^{111}$ For others, see Davies, Caddick and Harbottle (n 35) para 28-03, where the authors identify nine circumstances under the current legal regime in the UK in which compulsory licences can be granted. 
works, ${ }^{112}$ and certifying by the state of licensing schemes that are consensually entered into. ${ }^{113}$ In addition, a Copyright Tribunal is established with wide powers of assessing the reasonableness of royalties and equitable remuneration, even if a licence emanates from the voluntary consent of the licensor. ${ }^{114}$

Thus, the CDPA empowers the state to intervene to permit the use of copyright works in the form of compulsory licences and statutory licences, regardless of the copyright owners' consent.

\subsection{Identifying Operative Facts}

The above discussion identified the powers that enable the change of jural relations from rightduty to privilege-no right, namely: powers of the property owner to consent, custom and state intervention. Since a licence is a group of operative facts that give rise to a privilege-no right relation, these operative facts describe the exercise of powers under each source. In this sense, identifying these sources of power also categorises these operative facts. With the help of this categorisation, let us try and find the operative facts under each source with greater specificity.

Operative facts must satisfy the description of facts first. A fact is the truth about events (as opposed to interpretation). ${ }^{115}$ When the source is consent, a licence will conventionally be regarded express if it is in writing or in spoken words. The fact that the copyright owner signs a licence agreement is an operative fact, since the singed agreement brings about the required change in jural relations from right-duty to privilege-no right. If the

\footnotetext{
${ }^{112}$ CDPA, s 144A.

${ }^{113}$ CDPA, s 143.

${ }^{114}$ CDPA, ss 145, 149.

115 Oxford English Dictionary Online, <http://www.oxforddictionaries.com/us/definition/american_english/ fact>, accessed 19 August 2016.
} 
licence is in spoken words, and not in writing, facts establishing that the relevant words were spoken, become the operative facts. These operative facts make up a consent-based express licence.

In relation to a custom, a licence based on a custom, and indeed the custom itself, are rarely stated in express terms. However, copyright owners do come together sometimes to identify the customary practices specific to that industry in the form of best practices, spelling out the acts permitted in relation to copyright works. ${ }^{116}$ These could be called custom-based express licences. In these cases, if the existence of the custom underlying the licence is challenged, the facts and circumstances establishing the custom will be the operative facts, as these bring about the required change in the jural relations.

As regards the state intervention as the source, the statutory provision that empowers the state to grant a compulsory licence is a statement of law, as opposed to a fact. The existence of such a provision in the statute is a fact, because it confirms the truth about its existence; but is not an operative fact, since the existence of the provision alone does not bring about the required change in the jural relations. In furtherance of such statutory provision, the relevant authority will consider submissions from the prospective licensee as to the facts such as, the scarcity of the relevant copyright work, the price at which it is available, and the like. Assessing these facts, the relevant authority issues an order for compulsory licence. All these facts become operative facts, since these facts bring about the required change in the jural relations. And since the statutory provisions embody the particular policy goals to be achieved, compulsory licences are an example of policy-based express licences.

\footnotetext{
116 As regards user groups getting organised to create practices of their own, see generally, Patricia Aufderheide and Peter Jaszi, Reclaiming Fair Use: how to put balance back in copyright (University of Chicago Press, 2011).
} 
Since most of the statutory provisions empowering the issuance of compulsory licences appear in the same chapter in the CDPA as the other L\&Es, ${ }^{117}$ it is important here to establish why L\&Es do not give rise to licences, whereas compulsory licences do. One view is that compulsory licences always require payment to be made in exchange for their grant, whereas L\&Es do not. ${ }^{118}$ From a Hohfeldian perspective, all L\&Es bring about a change in the jural relations to privilege-no right, because in the absence of these statutory provisions the users would have owed a duty not to engage in the specific uses. However, L\&Es may still not create licences because as statutory provisions they are statements of law, and not statements of facts. It is arguable that the fact of an L\&E's existence in the statute is itself a fact that brings about the required change in the jural relation, and therefore an L\&E itself is a licence. In this limited sense, one might argue that all L\&Es are policy-based express licences.

However, the L\&Es permit uses of copyright works even without the users approaching a court seeking such permission. Some L\&Es like fair dealing do grant a discretion to the courts to interpret what is fair, but it does not stop the users from using copyright works for criticism and the like, as provided under s 30, CDPA. Further, the 2014 amendments to Part I, Chapter III of the CDPA render unenforceable a contract term that prevents or restricts the respective L\&Es taking effect. In this sense, the L\&Es behave more like statutory rules that grant users rights, placing duties on copyright owners to honour such rights. Canadian case law unequivocally refers to L\&Es as users' rights. ${ }^{119}$ On the other hand, there is no compulsory licence without the relevant authority granting one, because the relevant authority has a discretionary power to grant it. Only upon the exercise of such power a privilege is

\footnotetext{
${ }^{117}$ CDPA, Part I, Chapter III.

118 Davies, Caddick and Harbottle (n 35) para 28-02.

${ }^{119}$ CCH Canadian Ltd v Law Society of Upper Canada [2004] SCC 13 [12].
} 
created. All the facts that go into the exercise of the discretion become the operative facts, making a compulsory licence a licence in the Hohfeldian sense.

\subsection{Revocability}

The categorisation above is important also to shed light on a certain characteristic of a licence, namely its revocability. Revocation is different from termination. Any contract can be terminated at will, but consequences follow if such termination is in breach of contract terms, and the person terminating is liable for remedies including damages. However, revocation is a unilateral act and has no such consequences for the person revoking, as it only amounts to a withdrawal of the licence. Revocability of a licence affects its durability, and therefore, it matters to know under what circumstances a licence is revocable. Whether a licence is revocable depends firstly on the source of power that creates it, and secondly on the other FLCs that the licensor may have brought upon herself.

\subsubsection{Revocability under different sources of power}

If a licence is the result of the exercise of the power of ownership to consent for the property to be used by someone else, then it can be taken back as it was given, upon giving reasonable notice. ${ }^{120}$ This rule, supported by case law, ${ }^{121}$ is consistent with the Hohfeldian analysis. Hohfeld conceptualises property ownership as an aggregate of rights, privileges, powers and immunities. To Hohfeld, power is 'one's affirmative "control" over a given legal relation as against another'. ${ }^{122}$ The result of such control is that there is a choice whether to exercise a specific power, and when it is exercised, it can be taken back. Therefore, where the basis of

\footnotetext{
${ }^{120}$ Jonathan Hill, ‘Termination of bare licences’ [2001] CLJ 89, 98.

${ }^{121}$ For example, Brighton v Jones [2004] EWHC 1157 (Ch) [77]. See generally, Chapter III, section 2 below.

122 Hohfeld 1 (n 48) 55.
} 
creating a licence is the exercise of the powers of ownership, it is revocable upon reasonable notice, as a general rule, subject to further conditions under section 2.3 .2 below.

In contrast, if the owner did not exercise her power of ownership to issue the licence, but instead was compelled by the state to do so, then it follows that she cannot exercise her powers of ownership to take the licence back. In this case, the power in Hohfeldian sense is exercised by the state to achieve a policy goal. When the state exercises this power to compel the issuance of a licence, it creates a corresponding liability in the property owner to do so. ${ }^{123}$ To Hohfeld, liability is a state of being bound or obliged. ${ }^{124}$ Therefore, where the source of licence is the property owner's liability in the sense of being bound to issue a licence for public policy reasons, such licence cannot be revoked by the copyright owner at will. As such, when a copyright owner is ordered to issue a compulsory licence, even if she is able to negotiate the terms of the licence, she cannot revoke it at will. ${ }^{125}$ For any alteration of the terms of a compulsory licence, the copyright owner must approach the relevant authority that compelled her to issue the licence. ${ }^{126}$

When a licence is created based on a custom, the power in Hohfeldian sense exists in the binding nature a custom has attained due to its certainty, notoriety and reasonableness. Although a custom is rooted in the consent of a community representing the copyright owner, the content of this power is to compel the relevant behaviour, namely creating a licence, in order to meet the reasonable expectation that the custom will be followed. This power likewise

\footnotetext{
123 The jural correlative of power is liability. ibid 44.

124 ibid 53.

125 There is no direct authority on revocability of compulsory licences. But it is in the 'compulsory' nature of the licence that such unilateral revocation is not possible. See for example Davies, Caddick and Harbottle (n 35) para 28-02, where the authors regard an order of the court compelling the copyright owner to issue a compulsory licence, as changing property rules to liability rules.

126 See generally, Broadcasting Act, 1990, Schedule 17.
} 
creates a corresponding liability in the property owner to create the licence, and therefore, such a licence cannot be revoked by the copyright owner at will. ${ }^{127}$

\subsubsection{Other FLCs contributing to revocability}

A licence being the result of the exercise of ownership powers to consent does not mean that it is always revocable. When a permission is granted as a unilateral exercise of the powers of ownership, as in the case of a bare licence, the owner of the property is not obliged to ensure the continuance of the permission, as discussed above. In a bare licence which only has privilege-no right relation, there is simply no duty on part of the licensor to continue the permission granted. As such, the licensor of a bare licence who grants by her free will, is free to revoke the licence at will.

Although revocability gives flexibility to the property owner, it makes the legal relationship created, namely a bare licence, less durable. There are ways in which the issue of revocability can be addressed. A licensee can negotiate for the licensor not to exercise her powers of revocation. We saw in section 1.3.2.4 above, that a licence can be granted in exchange for consideration in a contract, for value or some benefit. Under these circumstances, a duty is imposed on the licensor not to revoke the licence at will. In this sense, a contract is often used as a tool to render a licence irrevocable, making it different from a bare licence. For example, $\mathrm{P}$, an architect, draws the architectural plans of a house for $\mathrm{Q}$ for a fee. The fee Q pays is in exchange for the privilege of using P's plans to build a building. By accepting the fee, P places herself under a duty not to revoke Q's licence to use the plans. ${ }^{128}$

\footnotetext{
127 There is no case law in the UK specifically addressing this point. However, if a licence granted by custom could be taken back by the copyright owner at will, it would go against the binding nature of a custom.

128 See Blair (n 3) for a similar situation.
} 
Although consent-based bare licences are revocable, they can become irrevocable under certain circumstances. This happens when the law imposes a disability on the property owner from revoking the licence. This occurs in cases of proprietary estoppel where the licensee, relying on the licence, changes her position to her detriment in such a way that the law will impose on the licensor a disability from revoking the licence, and a corresponding immunity from revocation in the licensee. Proprietary estoppel is used as the basis for rendering a bare licence irrevocable, or revocable only prospectively. Therefore, it is important for a copyright owner to know when the licence she grants might become irrevocable, so that she can take steps to prevent such irrevocability. ${ }^{129}$

\section{Frameworks for Implying Copyright Licences}

Thus far, having found the land law and copyright law notions of a licence unhelpful, section 1 used Hohfeldian analytics to show that a licence consists of a group of operative facts that give rise to privilege-no right relation. Hohfeld's is a general conception of licence, which, though helpful, is too broad to explain a copyright licence. As such, section 2 sought to identify these operative facts by first identifying the sources of power that enable the grant of an express copyright licence. The sources identified were: ownership power to consent to a use, a custom and the state intervention. This section will identify the operative facts that lead to implying a copyright licence, by using the Hohfeldian conception of a licence from section 1 and the sources of power in section 2 .

The purpose of identifying the sources of power to grant express copyright licences is to argue that normatively, the same sources should be invoked for implying a copyright licence. Thus, courts can imply a copyright licence either because of the copyright owner's consent or

\footnotetext{
${ }^{129}$ See Chapter III, section 2.2 for a discussion on proprietary estoppel in copyright cases.
} 
because of a custom, or because the state intervenes for a policy reason to imply a licence. These are powers invoked also in contract law for implying a term into a contract: voluntary conduct reflected in the intention of the parties (implied-in-fact), a custom (implied by custom) and the state intervention (implied-by-law). ${ }^{130}$ Courts cannot invent new sources of power, as these are well-recognised sources of private and public ordering. Confining the courts to these sources brings legitimacy to the otherwise controversial process of implication.

Hohfeldian conception of a licence remains the same whether the licence is express or implied, since it applies to licences that arise generally under any circumstance. Therefore, the jural relation of privilege-no right does not change. The operative facts differ. In express licences, it is more certain how one must go about establishing the operative facts when each of the powers to consent, of custom and of state intervention, are exercised, as discussed in section 2.2 above. In implied licences, by definition, there are no express terms, although we know these are the very powers we must invoke to imply a licence. Consider the examples below corresponding to each source of power.

In relation to consent-based express licences, if we want to see whether an author, $\mathrm{P}$, has given consent for her novel to be made into a feature film, we look at the operative facts that $\mathrm{P}$ has signed the licence agreement with the film producer. If a licence is to be implied, however, by definition, express terms will be absent. We will have to ascertain consent based on the conduct of the copyright owner and other circumstances, which will together form operative facts. We need a systematic way of finding these operative facts.

In a custom-based express licence, for example, when a person writes a comment on an online newspaper article, the custom prevalent in the industry that the newspaper has a

\footnotetext{
${ }^{130}$ See generally, McMeel (n 97).
} 
licence to retain a copy of such comment may be embodied in the newspaper's terms of use online. We look for the operative facts that establish such embodiment in the terms of use. If a licence is to be implied however, by definition, such terms of use will be absent. The user will have to establish the existence of a custom to this effect, if the existence of the custom is at issue. The facts and circumstances that go into establishing the custom will be the operative facts. We again need a systematic way of finding these facts.

Similarly, in relation to policy-based express licences such as compulsory licences, for example, the policy that the state should provide access to certain copyright works on reasonable terms is embodied in the statute. Based on this statute, a person may approach the relevant authority for an order compelling the copyright owner to issue a licence. We look for the operative facts that make a case for the authority to issue such an order in exercise of its powers. If a licence is to be 'implied' based on a policy however, by definition, there is no express embodiment of such policy in the statute. If a user wants the court to compel the issuance of such a licence, the user must convince the court that it has powers to validly enforce such policy. If convinced, the court will exercise such power considering all facts and circumstances, which will become the operative facts. We again need a systematic way of identifying these facts.

My effort in this section is to propose discrete, but related frameworks to systematically identify the operative facts that underlie an implied copyright licence. I have developed these frameworks inductively by analysing the recurring patterns in the case law and the provisions of the CDPA, through the prism of Hohfeldian analytics. I propose these frameworks as a set of criteria to marshal operative facts resulting from the exercise of each source of power. Faced with an infringement, when a court has only facts and circumstances of a case before it, these criteria become a guide to assess whether the facts and circumstances support implying a licence. I do not propose these criteria as rigid requirements, denying implied licences of their 
much-valued flexibility. The objective in identifying these criteria is to make the process of implication transparent. I will explain below why I have chosen the specific criteria and their normative relevance, for each source of power.

A licence can arise as a bare licence or as a contractual licence. This distinction influences to varying degrees, the frameworks proposed and the methodology adopted for implying a licence under the respective sources. While such variations result in different chapters being devoted for bare and contractual licences in relation to consent-based and policy-based implied licences, the distinction is less relevant for custom-based implied licences. The discussion below also addresses this distinction for each source.

\subsection{Consent of the Copyright Owner}

Consent freely given is a state of mind which is objectively assessed based on the conduct of the copyright owner and the surrounding circumstances, all of which present themselves as facts. ${ }^{131}$ For this reason, this manner of implication is also called 'implied-in-fact'. However, when a copyright owner gives her work to someone without stating anything, the default position should be that she consented to licence its use, and not that she alienated the property. Therefore, establishing consent is key to implying a licence based on such consent. Thus, I use the term consent-based implied licence in preference for implied-in fact licence. The framework below proposes criteria to marshal the operative facts that establish consent, in the absence of any express terms indicating the copyright owner's consent.

\subsubsection{The framework}

We saw above that copyright owner consenting for her work to be used is in exercise of her

${ }^{131}$ Edwin Peel and James Goudkamp, Winfield and Jolowicz on Tort (19th edn, Sweet \& Maxwell 2014) para 26.01. 
powers of ownership. Therefore, consent as a state of mind manifests in the conduct of the copyright owner in enabling the licensee to use the copyright work. It is not sufficient to focus only on the conduct of the copyright owner. The knowledge of the copyright owner as to the surrounding circumstances is also equally important. ${ }^{132}$ Therefore, the operative facts that lead to consent can be broadly channelled between those that reveal the copyright owner's conduct and those that reveal the copyright owner's knowledge.

One may draw a parallel with the conceptual reasoning adopted in contract law where, to ascertain the existence of a contract, the courts look at the conduct of the parties such as offer, acceptance and so on, and the state of mind such as the intention to create legal relations. ${ }^{133}$ The offer, the acceptance and so on are more in the nature of pointers for the existence of a contract, rather than inflexible requirements. Similarly, the issue of whether a copyright owner has consented to licence her work can be ascertained from the pointers or the criteria that reflect the conduct of the copyright owner and her state of mind. Accordingly, the framework consists of what I call:

- the positive act;

- the neutral act; and

- the knowledge of the copyright owner.

The first two criteria correspond to the conduct of consenting, and the third criterion captures the state of mind of the copyright owner. I explain each of these criteria below.

\footnotetext{
132 Hugh Collins, The Law of Contract (4th edn, LexisNexis 2003) 130, where he states that it may be possible to imply consent to a contract by reference to 'the conduct and the knowledge of the ... party.' (emphasis added).

133 Atiyah and Smith refer to this approach of ascertaining the conduct of the parties (such as offer, acceptance and the like) to arrive at a conclusion as to the existence of a contract as 'conceptual reasoning'. Atiyah and Smith (n 65) 40-41.
} 


\subsubsection{Positive act}

In the discussion of privilege in the Hohfeldian conception of licence above, ${ }^{134}$ it was explained that the world at large owes a duty to the copyright owner not to interfere with her exclusive rights. Any transformation of such duty into privilege must be at the instance of and due to the conduct of the copyright owner, when consent is invoked for implying a licence. Such duty owed by the world at large cannot be negated by the copyright owner's inaction. ${ }^{135}$ There must be some overt conduct on part of the copyright owner that signals that such duty has transformed to a privilege to use the copyright work. I call such overt act the 'positive act'.

Additionally, inaction alone cannot be the conduct revealing the state of mind required for consent. If there is no overt act, it is not certain what might be in the copyright owner's mind. The copyright owner must engage in an overt act to signal that the copyright work is available for use, enabling another person to use it. The positive act captures this conduct. The positive act thus results in a privilege being created in another person (licensee) to use the work. For example, if $\mathrm{P}$ is a songwriter, the handing of a piece of paper by her on which her song is written, to a person A to sing it, will be a positive act.

The positive act can sometimes be conditional on providing consideration, such as paying a fee. This can happen in a contractual licence. A copyright owner can undertake to part with a work only in return for payment. For example, $\mathrm{P}$, a painter, might agree to create a portrait to handed over only upon an advance payment. In such a case, handing the portrait is the positive act, which is conditional on the negotiated payment.

\footnotetext{
${ }^{134}$ See section 1.3.1.1 above.

${ }^{135}$ A mere inaction is insufficient to transform the duty into privilege, unless there is a case for adverse possession. However, the UK copyright law does not recognise adverse possession. See Fisher v Brooker [2009] UKHL 41 [78] (per Lord Neuberger).
} 


\subsubsection{Neutral act}

The positive act is an essential, but not the only conduct. Since a privilege is granted due to the copyright owner's power to consent, it can be taken back at any time. ${ }^{136}$ To complete the act of consenting, having enabled the work to be used, the copyright owner must stand back when the licensee goes ahead to use the work. In the discussion above on no-right in the Hofeldian conception of a licence, ${ }^{137}$ the duality of privilege-no right relation that underlies a licence shows that there are two parts to showing licence: one that involves enabling and another involving standing back. While the conduct of enabling is captured within the positive act, the conduct of standing back is captured within what I call the 'neutral act'. The neutral act is therefore the manifestation of no-right.

The neutral act as a conduct of the copyright owner is as much a reflection of the state of mind of consenting as is the positive act. While the positive act signals the creation of a privilege, the neutral act signals the continuance of the privilege. Although the neutral act does involve a level of inaction, the inaction does not signal the creation, but only the continuance of the licence. Neutral act does not mean that the licensor acts negatively, because a negative act signals the end of a privilege. ${ }^{138}$ As long as the neutral act continues, the licence continues, thereby adequately covering the entire span of the state of mind from its inception to its end.

The neutral act maintains the status quo, such that where a copyright owner enables her work to be used by the licensee, she maintains the status quo for a length of time by not asserting her copyright. The neutral act may continue indefinitely, making the privilege

\footnotetext{
136 So long as the copyright owner has not placed himself under the duty not to revoke, as in case of a contract. See section 2.2.2 above.

${ }^{137}$ See section 1.3.1.2 above.

138 An example of a negative act is issuing a notice to stop the use of copyright work See Chapter III, section 2.1 below for a discussion on this point.
} 
continue accordingly; or may become a negative act, ending the licence. In this sense, the continuation of the neutral act accounts for the duration of the implied licence. There can be long periods of inaction on part of the copyright owner - in one particular case, 38 years. ${ }^{139} \mathrm{It}$ cannot be that the positive act of enabling a copyright work for use itself continues for 38 years. There must be something else in a licence that explains it. For Hohfeld, the copyright owner exercising no-right in relation to the work for 38 years, explains it.

The neutral act can be absolute in that it allows all consequences of the positive act to ensue, or can be partial in that only certain selective consequences of the positive act ensue. A positive act by nature cannot be partial. A person cannot partially give a piece of paper with lyrics on it. However, having given the work, the copyright owner can do something that conveys that she does not wish for all consequences of the positive act to ensue. She can select the parts of her copyright work that can be used or specify the uses that can be made of the work. In this sense, the neutral act is the conduct that controls the extent of the effect of the positive act. One must be sensitive to the neutral act for, otherwise, one might conclude that a wider use of the copyright work is consented to, than the copyright owner intended.

A partial neutral act results in a partially express licence, since it spells out what the user can and cannot do. Depending on how detailed the terms are, it might still be possible to imply a licence covering wider uses than those stated in the express words. This is particularly manifest in case of implied licences on the internet. A copyright owner placing her content on the internet, is a positive act. Leaving the content there and standing back is the neutral act with its full effect. However, if the copyright owner places certain terms of use on the internet, then the neutral act of standing back becomes partial, since only some of the consequences of

139 Fisher (n 135). 
the positive act of placing the content on the internet ensue. ${ }^{140}$

It is also possible for the neutral act to be conditional. This usually happens in contractual licences. ${ }^{141}$ Having enabled the use of the work by engaging in the positive act, the copyright owner standing back and letting the work to be used, may be subject to the licensee providing consideration, say in the form of payment.

\subsubsection{Knowledge of the copyright owner}

The copyright owner's ability to exercise her powers of ownership to consent requires that she knows what she is consenting to. ${ }^{142}$ Hohfeld does not specifically speak of knowledge as an element of consent. Hohfeld's work was focused on licences in general, and not only those that arise because of consent. However, it is possible to fit knowledge within the Hohfeldian operative facts together with the positive and the neutral acts. This is because the positive and the neutral acts cannot take place in vacuum. The copyright owner must know the state of affairs that the engaging in the positive and the neutral acts will bring about.

In general, the extent of knowledge of the copyright owner determines whether an implied licence or an implied gift comes into existence. If the copyright owner knows that the consequence of performing the positive and the neutral acts in relation to a copyright work is that the person in receipt of the work can exercise all ownership powers in relation to the work (including alienating the copyright in the work), then the court might imply a gift. If the copyright owner's knowledge only extends to the work being used by the person in receipt of

\footnotetext{
140 See Chapter VIII below.

141 See Chapter IV below.

142 The importance of knowledge is discussed in relation to informed consent in medical law by Simon Lee, 'Towards a Jurisprudence of Consent' in John Eekelaar and John Bell (eds), Oxford Essays in Jurisprudence Third Series (Clarendon Press 1987) 199, 213.
} 
the work in a way that involves performing a restricted act, then a court may imply a licence covering such restricted act. It is borne out in the case law that courts are slow to come to a conclusion that a copyright owner implied a gift, especially when the copyright owner parts with a copyright work without stating how the work may be used. ${ }^{143}$

Normatively, consent-based implied licences must take into account matters within the actual knowledge of the copyright owner. This is because the greater the reliance on the actual knowledge, the greater the possibility that the copyright owner's consent is voluntary. However, courts do take into account matters that ought reasonably to have been within the copyright owner's knowledge, especially in implying contractual licences, so that the reasonable expectations of the other contracting party are met. ${ }^{144} \mathrm{~A}$ copyright owner is imputed with the knowledge of a practice only if such practice has become a custom, the framework for which is discussed in section 3.2 below.

\subsubsection{Bare and contractual licences}

One may note from the discussion above that the existence of a contract impacts each criterion of the framework. Apart from the possibility of the positive and neutral acts being conditional on providing consideration, the content of the knowledge differs between implied bare licences and implied contractual licences. Implied bare licences require the copyright owner to know that the licence is gratuitous, and implied contractual licences require the copyright owner to have the knowledge of the bargain.

143 Banks (n 2) is an example. See Chapter III, section 1.3.3 below for discussion on implied bare licences, and Chapter IV, section 2.1.1 for a discussion in Robin Ray v Classic FM [1998] EWHC Patents 333 the higher threshold placed in implying an assignment in the contractual context.

144 See generally, Johan Steyn, 'Contract law: fulfilling the reasonable expectations of honest men' [1997] 113 LQR 433, 441. 
Further, I also propose to adopt a different method of analysis for implied contractual licences. An implied contractual licence has elements of both a contract and a licence. Accordingly, the methodology has two stages of implication - contract stage to assess the term to be implied (whether an assignment, exclusive licence or non-exclusive licence); and if a licence (exclusive or not) is to be implied, then licence stage, to determine the scope of the licence. These analytical steps are not necessary for consent-based bare licences, because by definition, such licences lack a bargain.

Given all these differences, it is necessary to deal with bare and contractual licences separately. Therefore, I analyse consent-based implied bare licences in Chapters III and consent-based implied contractual licences in Chapter IV below.

\subsection{Custom}

A custom can also be a source of implying a licence. Section 3.1.1 above provided the framework for establishing consent of one person - the copyright owner. Many such copyright owners may consent to a certain practice within their trade, consistently and notoriously, so much so that the actors within that trade begin to recognise such practice as binding. The continued engagement in such practice within the trade will reach a point where the practice will become binding also on a copyright owner who has no knowledge of it. This is the point where the practice is established as a custom. Applying the framework for consent in section 3.1.1 above will be inadequate, because, even if the copyright owner has no knowledge of the relevant practice, such knowledge is imputed to him. Therefore, the framework one needs here should address not the conduct of the copyright owner and her state of mind, but the manner in which the knowledge of the practice can be imputed to the copyright owner. The ability to impute the knowledge of a practice comes from the practice being clearly identifiable, consistent, universally followed and so on. In other words, these are the criteria that establish such practice as a custom. 


\subsubsection{The framework}

The criteria for the establishment of a custom already exists in contract law, ${ }^{145}$ since historically, contract law has had a greater engagement with customs. ${ }^{146}$ Since customs perform the same function in contract law, which is to impute knowledge of it to the contracting parties, the same criteria apply also for establishing a custom for implying a copyright licence. The following are the criteria for the establishment of a custom, as generally agreed by scholars and judges in the UK. ${ }^{147}$

- Certainty;

- Notoriety;

- Reasonableness;

- Not contrary to law; and

- Recognised as binding

A more detailed discussion follows in Chapter V below. Scholars of copyright law, especially in the US, have further refined the criteria for the recognition of a custom within the copyright context, keeping in mind the ability of more powerful players in copyright industries to create and maintain practices to their sole advantage, and to the detriment of the less powerful players like the end-users. ${ }^{148}$ Accordingly, Chapter $\mathrm{V}$ further refines the main criteria above, and discusses the case law on custom-based implied copyright licences, in the light of the main and the refined criteria.

${ }^{145}$ McMeel (n 97) para 12.13.

146 See generally, Sir Johan Steyn, 'Written Contracts: To What Extent May Evidence Control Language?’ [1988] CLP 23, 26.

${ }^{147}$ McMeel (n 97) para 12.11; Beatson, Burrows and Cartwright (n 65) 169.

148 Rothman (n 101); see Chapter V, section 2.1 below. 


\subsubsection{Bare and contractual licences}

These licences can also arise as bare or contractual licences. However, the issue of concern is often, the very existence of a custom, rather than the bare or contractual nature of the licence. Therefore, both these forms of licences are dealt with together in Chapter V below.

\subsection{State Intervention to Achieve a Policy Goal}

Just as it is possible for the state to intervene for public policy reasons and order a copyright owner to issue a compulsory licence, it should be possible for the state to intervene for public policy reasons to imply a licence. A licence implied based on public policy is sometimes called a licence implied-by-law, because it is a source of law (statute or common law) which enables the state intervention. I prefer to call it policy-based implied licence, because the reason for the implication here is the achievement of a public policy goal. These licences also arise both as bare licences and contractual licences.

The clue to the framework here lies in unpacking and analysing the way policy-based express licences (such as compulsory licences) arise. See the table below. There are four aspects to this analysis, which are set forth in the left-had column. The middle column shows what each aspect corresponds to in a policy-based express licence. The right-hand column shows what we ideally want to see in the framework for implying a policy-based implied licence.

Table I

\begin{tabular}{|l|l|l|}
\hline Source of law & $\begin{array}{c}\text { Policy-based express licence } \\
\text { (Compulsory licence) }\end{array}$ & $\begin{array}{l}\text { Ideal parameters for implying } \\
\text { a policy-based licence }\end{array}$ \\
\hline $\begin{array}{l}\text { Statutory (the CDPA has specific } \\
\text { provisions) }\end{array}$ & Common law rule \\
\hline $\begin{array}{l}\text { Embodiment of } \\
\text { the policy }\end{array}$ & $\begin{array}{l}\text { Specifically embodied in the } \\
\text { provisions (E.g. to make a } \\
\text { copyrightable work available at a } \\
\text { reasonable price) }\end{array}$ & $\begin{array}{l}\text { Open-ended, so that the state } \\
\text { actor can deal with any situation } \\
\text { brought before it. }\end{array}$ \\
\hline
\end{tabular}




\begin{tabular}{|l|l|l|}
\hline $\begin{array}{l}\text { State actor } \\
\text { assessing the } \\
\text { case }\end{array}$ & $\begin{array}{l}\text { Administrative authorities (such } \\
\text { as Secretary of State or the } \\
\text { Copyright Board) }\end{array}$ & $\begin{array}{l}\text { A court, since a court can } \\
\text { normally exercise a wider } \\
\text { discretion than an administrative } \\
\text { authority designated by a statute, } \\
\text { and to be unconstrained by } \\
\text { international obligations. }\end{array}$ \\
\hline $\begin{array}{l}\text { Assessment of } \\
\text { factors and } \\
\text { decision }\end{array}$ & $\begin{array}{l}\text { Factors that support the specific } \\
\text { policy objective of the } \\
\text { compulsory licence. }\end{array}$ & $\begin{array}{l}\text { Factors that help ascertain a } \\
\text { policy objective, and those that } \\
\text { help achieve such objective. }\end{array}$ \\
\hline
\end{tabular}

The crux of a policy-based implied licence lies in the open-endedness of the list of policy objectives that can be achieved (shaded box). In summary, the framework should identify a line of common law authority that empowers a court to ascertain from an openended list of policy objectives, the one that applies to the case before it, and to assess the facts and circumstances that help achieve such objective.

\subsubsection{Policy-based implied licences vis-à-vis L\&Es and compulsory licences}

Before we attempt formulating a framework, it is essential to establish the nature of policybased implied licences vis-à-vis L\&Es and compulsory licences. Both L\&Es and compulsory licences apply regardless of a copyright owner's consent. In other words, the use that an L\&E or a compulsory licence enables is involuntary as far as the copyright owner is concerned. To the extent that policy-based implied licences also disregard the consent of the copyright owner, one might argue that these behave like L\&Es and / or like compulsory licences. However, this is not the case. Indeed, this thesis argues that the policy-based implied licences are a category of their own. Both L\&Es and compulsory licences are subject to certain constraints under the international and / or EU law. Establishing policy-based implied licences as a category of their own liberates them from these constraints.

A policy-based bare licence may have been regarded akin to an L\&E in that it requires no payment to be made for the use of copyright work. However, an L\&E is distinguishable in its nature and origin. L\&Es are in the nature of users' rights, as explained in section 2.2 above, 
and a policy based implied licence at its core, only grants a privilege, and not a right. L\&Es are necessarily statutory in origin and a policy-based implied licence has its origin in common law. The relevant obligations under the international treaties and EU directives are primarily upon the legislatures of the respective member states, to design their statues accordingly. As explained in Chapter VII below, these obligations (including the three-step test) do not affect policy-based implied bare licences.

Compulsory licences are also licences in the Hohfeldian sense as explained in section 2.2 above. But, they are distinguishable from policy-based implied licences again based on their nature and origin. Although no statute, nor an international treaty defines them, compulsory licences have a technical connotation. An explanation can be found in the WIPO Glossary, which states that an equitable remuneration is a condition for the grant of all compulsory licences. ${ }^{149}$ Since compulsory licences are in exchange for a fee, they are contractual licences. They are, therefore, readily distinguishable from policy-based implied bare licences. Compulsory licences are also distinguishable from policy-based implied contractual licences in that in the latter, there is a pre-existing contract into which a licence is implied for the value already given in that contract. In a compulsory licence, on the other hand, the contract is imposed on the copyright owner in furtherance of the policy, even if the copyright owner and the proposed licensee are able to negotiate the payment and other terms of the licence. Chapter VI explains this further and what this means in relation to international obligations.

One may argue that nothing stops a compulsory licence being granted without compensation. However, this goes against the commonly held notion of a compulsory licence.

149 WIPO Glossary of the Terms of Law of Copyright and Neighbouring Rights, 1983, p. 50, definition 50. 
Additionally, compulsory licences are also statutory in origin. ${ }^{150}$ Historically, the legislature has been tasked with the formulation of the public policy to be achieved and the conditions of grant, and of embodying it in a statute. ${ }^{151}$ Within the rubric of this thesis (as explained in section 2.2 above), compulsory licences are an example of policy-based express licences to the extent that the public policy to be achieved and the conditions of grant are identifiable and are embodied in a statute. On the other hand, it is a court that determines the conditions of implication of a policy-based licence, both in case of a bare licence and a contractual licence. And the implication is supported by a public policy derived from an open-ended list. The open-endedness and the diversity of circumstances that can be addressed by a court is what makes it a policy-based implied licence, and thus, distinguishable from compulsory licences. The impact of this on the UK's international obligations is discussed in greater detail in Chapter VII below.

\subsubsection{The framework}

The framework must not only identify the common law source, it must also provide guidance for the exercise of such open-ended power. Since the existence of a contract makes a significant difference to the framework applied, policy-based implied contractual licences are considered separately from policy-based implied bare licences, as follows.

\subsubsection{Policy-based implied contractual licences}

Historically, the existence of a contract has given the courts the legitimacy to imply a term into

\footnotetext{
150 Jane Ginsburg, 'Creation and Commercial Value: Copyright Protection of Works of Information' 90 Colum L Rev 1865, 1926, where the author describes compulsory licences as 'legislative judgment that certain classes or exploitations of works should be more available to third parties...'.

151 See Davies, Caddick and Harbottle (n 35) para 28-04, where the authors describe the historical origin of compulsory licences dating back to the Literary Copyright Act, 1842, and then under the Copyright Act, 1911, and the Copyright Act, 1956.
} 
a contract not because the parties intended it, but more in order to achieve a policy goal. Contract law has a well-developed line of common law authority providing a methodology for implying a term by law into a contract. The methodology is useful also in case of a policybased implied contractual licence, although the nature of the term to be implied is not generally any term in a contract, but is specifically in the nature of a licence. The methodology, which we may adopt as the framework is as follows:

- Defining the type of contract into which the contract in the case presented before the court can be classified, so that if a licence is implied, it applies to all contracts of that type; and

- Ascertaining reasonable necessity, which involves the court ascertaining whether the implication of the licence is reasonably necessary.

Chapter VI below applies the methodology to the copyright context in support of implying a policy-based contractual licence.

\subsubsection{Policy-based implied bare licence}

Section 171(3), CDPA states that 'Nothing in this Part affects any rule of law preventing or restricting the enforcement of copyright, on grounds of public interest or otherwise. ${ }^{152}$ This provision is included under the savings provisions under the sub-heading 'Rights and privileges under other enactments or the common law', conveying that if there was a common law rule in existence at the time of the enactment of the CDPA, restricting or preventing copyright enforcement, this provision saves such rule. ${ }^{153}$

\footnotetext{
152 Emphasis added.

153 Robert Burrell, 'Defending the public interest', [2000] EIPR 394, 402-03, where the author establishes that such common law rule did exist and the law makers were aware of such rule.
} 
Such a common law rule, if it exists, is broad enough to prevent the enforcement of copyright altogether. However, if a court decides only to restrict the enforcement of copyright, it might do so to achieve public interest in permitting someone else to use the copyright work. Thus, the exercise of the court's powers can change a user's duty not to use, to a privilege to use the relevant work. In exercising its powers, the court assesses the facts of the case before it, ascertains the policy to be given effect to, and decides accordingly. Thus, a court's decision exercising the power under s 171(3) can become a policy-based implied licence, with the facts going into the decision-making as the operative facts. Since the provision does not require the permission to be in exchange for consideration, the licence implied is a bare licence.

The CDPA does not provide for how a court's discretion under s 171(3) is to be exercised. Under these circumstances the three-step test may still provide a good methodological guideline for the courts to exercise their discretion.

However, even if the implication of a policy-based bare licence does not satisfy the three-step test, then the court may still assess its compliance with the fundamental rights regime. The fundamental rights regime is an important constitutional source to guide state action. It consists of the ECHR and the CFREU.154 The rights guaranteed by the ECHR are regarded guiding principles of EU law, but will be binding on the EU institutions (both legislative and judicial) if the EU accedes to the ECHR. ${ }^{155}$ However, UK is a signatory of the ECHR, ${ }^{156}$ and has implemented its provisions through the HRA. The CFREU, which was not

\footnotetext{
154 Proclaimed on 7 December 2000. < http:/ / ec.europa.eu/justice/fundamental-rights/charter/index_en.htm>, accessed 25 October 2016.

155 TEU, art 6(2). Protocol No 14 to the ECHR places an obligation on the EU to accede to the ECHR. However, the CJEU in Case-2/13 gave an Opinion (ECLI:EU:C:2014:2454) holding that the Draft Accession Treaty is incompatible with EU law.

156 The UK became a signatory to the ECHR in 1950. < http://www.coe .int/en/web/conventions/search-ontreaties/-/conventions/treaty/005/signatures?p_auth=Y7H4FIGv>, accessed 6 October 2016.
} 
binding in the past, is now binding and is placed at the same level as the TEU. ${ }^{157}$ The provisions of the ECHR and the CFREU, therefore, enjoy a higher standing in the hierarchy of rules applicable in the UK, than the three-step test, which is provided only in an EU directive. Thus, if a court exercising its common law powers under s 171(3) complies with the fundamental rights regime, even if it does not comply with the three-step test, a policy-based licence can be implied.

Accordingly, the framework consists of the following: can a court imply a policy-based bare licence on the strength of its common law powers under s 171(3):

- being guided by the three-step test; or

- in compliance with the fundamental human rights regime.

Chapter VII below discusses in greater detail the scope of a court's powers under s 171(3).

\section{Rationalising the Existing Case Law with the Frameworks}

This Chapter set out first to identify a conception of licence that is sufficiently particularised to spell out its constituents, but is also sufficiently broad and general to capture the diverse circumstances in which copyright licences arise. Having found such conception in the Hohfeldian analytics, it set out to ascertain how express licences arise, so that it is possible to show how an implied licence should arise. It analysed the aspects that are present in express copyright licences from the perspective of the Hohfeldian conception of licence, and tried to find the corresponding criteria to act as guidelines while implying a copyright licence. These criteria serve as the building blocks for the frameworks proposed in this Chapter. These frameworks can bring transparency to the appreciation of the facts and circumstances

157 TEU, art 6(1), as amended by the Treaty of Lisbon [2007] OJ C306/01. 
supporting the implication of a licence under different circumstances.

How do we take the discussion from here? How do we use case law to demonstrate in the Chapters to follow that applying the frameworks proposed do lead to the projected objective being served namely, a methodical and transparent manner of implication?

In arriving at the framework for consent-based implied licences, I have adopted the inductive method by analysing the specific cases concerning copyright licences, to arrive at the criteria into which the operative facts can be channelled. In contract law, judges arrived at the criteria such as offer, acceptance and so on, based on a similar exercise. However, the criteria such as offer, acceptance and so on are well accepted, and find specific mention in the judicial reasoning. Understandably, it is not the case for the criteria I propose here. Courts normally only provide a general discussion on the conduct of the copyright owner. Where the knowledge of the copyright owner is discussed, there is no systematic assessment.

I therefore, rationalise these criteria in my discussion of the case law in Chapters III and IV. By rationalising I mean a more conscious analysis of the facts and circumstances of the cases that have arisen relating to consent-based implied licences in the light of the framework proposed. Doing so can make the court's decision more transparent, so one can assess the soundness of the courts' reasoning, and if found lacking, suggest how it may have been improved. I begin this process with consent-based implied bare licences in Chapter III, and move on to consent-based implied contractual licences in Chapter IV.

The discussion will then move to custom-based implied licences, for which the criteria are those that establish a practice as a custom (main criteria), and the refined criteria. Although the main criteria are well established in contract law, in the copyright cases there is no adequate discussion of the main or the refined criteria. Therefore, rationalisation in this context means applying the main and the refined criteria to complete the reasoning in copyright cases, and arriving at conclusions that are logically sound and doctrinally well-supported. 
The discussion will finally move to policy-based implied licences. The frameworks involved finding a rule of common law that empowers a court to pursue an open-ended list of policy objectives, and certain guidelines as to how such power may be exercised. In case of contractual licences, the framework is not new; but it has not been expressly applied to copyright cases. Therefore, rationalising the existing case law will involve analysing it in the light of this framework, which is dealt with in Chapter VI below. In case of bare licences, s 171(3), CDPA was enacted based on a line of case law, but no court or commentator regards it as a licence implied based on policy. The case law does not discuss the three-step test guiding the exercise of the court's jurisdiction under s 171(3), although there is a brief reference to the fundamental rights regime. ${ }^{158}$ Rationalisation in this regard involves analysing the case law in the light of the framework proposed, which is dealt with in Chapter VII.

Chapter VIII then takes up all the conclusions derived from the process of rationalisation, and applies it to ascertain if certain basic functionalities on the internet, namely browsing, hyperlinking and indexing, can be authorised by these implied copyright licences.

158 Ashdown v Telegraph Group Limited [2001] EWCACiv 1142 [58]. 


\section{Consent-based Implied Bare Licences}

This Chapter will consider licences where no terms are express and no consideration flows back to the copyright owner in return for the licence, either payment or otherwise. We call this a bare licence. ${ }^{1}$ The operative facts considered here are those that point to the existence of consent, which lead to a privilege-no right relationship, and no other, such as rights or duties. ${ }^{2}$ The modern relevance of a consent-based implied bare licence lies in its application to the copyright work placed on the internet by its owner or with her consent, without terms of use. ${ }^{3}$

The copyright owners might often be interested only in communicating their works to their audience and thus, to gain reputation for their works. They may often not have the expectation of any other reward. However, the case law discussed in the Chapter will demonstrate that there are certain other reasons behind a copyright owner might granting a bare licence, outside casual or friendly circumstances. Firstly, the copyright owner might not realise that a copyright work has come into existence; secondly, even if she does realise it, she might not realise her own entitlement to it; thirdly, even if the copyright owner does realise her entitlement, she might not claim a share in the ownership due to, inter alia, the lack of bargaining power to assert her entitlement.

Consent, as explained in Chapter II, is a state of mind assessed based on the conduct of the copyright owner and her knowledge of the circumstances. The conduct that creates a privilege-no right relationship is the positive act (facilitating her work to be used) and the neutral act (refraining from interfering with such use). Consent must be coupled with the

\footnotetext{
${ }^{1}$ See Chapter II, section 1.3.2.3 above.

2 A group of operative facts that create privilege is a licence, in Hohfeldian terms. Wesley Newcomb Hohfeld, 'Some Fundamental Legal Conceptions as Applied in Judicial Reasoning' [1913-14] 23 Yale LJ 16, 44.

${ }^{3}$ See Chapter VIII, section 1.3.1 below.
} 
knowledge of what one is consenting to. These components are embodied in the framework proposed in Chapter II.

When one examines the existing case law, the only 'rule' which the courts acknowledge they must follow when implying a copyright licence is to consider all facts and circumstances. ${ }^{4}$ This is too general and gives no guidance at all as to how the courts come to the conclusions they do. Even if the courts discuss generally the conduct of the copyright owner, it is not clear how such conduct could be identified in future cases. Even when the courts discuss the knowledge of the copyright owner, there is no systematic analysis of the aspects of the knowledge one must look for. Since one gets no guidance at all from the decisions as to the factors that go into implying a consent-based bare licence, it results in uncertainty and a hesitation to imply licences in newer scenarios.

Therefore, in section 1, I rationalise the decisions of the UK courts concerning consent-based implied bare licences, with the framework proposed in Chapter II. By rationalising, I mean consciously analysing the cases in the light of the proposed framework. ${ }^{5}$ Of course, the courts do not use the terminology of the framework, namely the positive act and the neutral act. However, from the general discussion of evidence, it is possible to identify facts that could otherwise make up the positive and the neutral acts. Identifying these facts under these criteria makes the courts' reasoning more transparent. It also makes one become more conscious of the conduct necessary for consent. A similar goal can be achieved by analysing the decisions under the third criteria of the framework, namely the knowledge of the copyright owner. In some cases, the process of rationalisation also helps reveal any unsoundness in the courts' reasoning, and suggest ways to set them right.

\footnotetext{
${ }^{4}$ Banks v CBS Songs Ltd [1996] EMLR 440, 499.

${ }^{5}$ See Chapter II, section 4 above.
} 
Section 2 deals with the revocability of a bare licence. A consent based bare licence can be revoked, since the ability to grant such a licence and to revoke it (upon reasonable notice) both originate from the powers of the copyright owner. However, there are situations where these licences cannot be revoked, and the courts have ascribed proprietary estoppel as the reason for irrevocability. Since the doctrine of proprietary estoppel originated in land law, land law cases are applied to support proprietary estoppel in copyright law. Based on the principles derived from the land law cases, this chapter advocates the application of proprietary estoppel in a manner more adapted to the needs of copyright law, so that it can lead to fairer results.

Section 3 concludes with a summary of the process of rationalisation in section 1 and its impact on the discussion of proprietary estoppel in section 2, and goes on to make connections with Chapter IV.

\section{Establishing Consent}

Chapter II identified the framework for implying a consent-based licence as follows:

- the positive act;

- the neutral act; and

- the knowledge of the copyright owner.

For bare licences, the third criterion splits into several sub-ingredients, as discussed below.

\subsection{The Positive Act}

Chapter II explained that the positive act is the act of enabling the copyright work to be used by the licensee. In the absence of an express grant, one must start with an 'overt conduct' on part of the copyright owner that indicates her state of mind to consent. Mere inaction is insufficient. 
The cases concerning consent-based implied bare licences discussed in this Chapter are not cases of mere inaction. The copyright owner does admit to engaging in an overt act, and therefore, in most cases there is no discussion on the importance of such overt act to prove consent. However, in cases where there is no overt act of whatever kind, courts have normally refused to recognise a licence. The Australian High Court decision in Interstate Parcel Express Co Pty Ltd v Time-Life International (Nederlands) $B V{ }^{6}$, is perhaps the most explicit in this regard. It was argued here that the lack of restriction by an overseas copyright owner on the importation of certain magazines into Australia was sufficient to amount to a licence to import these magazines. The court rejected this argument, and held that a 'positive licence' would be required, which may not be express, but implied where 'a copyright owner overseas sells copyright articles in commercial quantities to a purchaser in Australia. ${ }^{77}$ Thus, in this case, the selling of commercial quantities of copyright articles to an Australian purchaser could have been regarded as the positive act. In its absence, there was no licence.

Since the case law in the UK is more tacit in its acceptance that without the positive act, a copyright owner cannot demonstrate her consent, this section makes explicit the act or the series of acts that represent the positive act. The objective is to make transparent the need for the positive act, so that in future, a court does not erroneously conclude that consent exists even where there is no positive act.

The manifestation of a positive act depends on the nature of the work. If it is a literary or dramatic work, handing the piece of paper on which it is written or is printed would be a positive act. If it is a musical work, the positive act may manifest in taking part in the recording. Normally the conduct of creating the work precedes the positive act, but may not in itself be

\footnotetext{
${ }^{6}$ (1977) 138 CLR 534.

7 ibid 556-7 (emphasis added). The judge was speaking of ACA, s 37.
} 
sufficient to be the positive act. The positive act is a conduct noticeable in addition to the process of creation, evident either from a physical transfer of the work, or from the circumstances that enable the work to be used.

One may begin illustrating it with Banks v CBS Songs Limited. ${ }^{8}$ In this case, Deborah Banks, the claimant, was acquainted with Khan, a mechanist, when he told her that he had an opportunity to sing for the rock group UB40. Banks claimed that Khan had asked her to 'come up' with some words, and Khan claimed that he himself wrote the words with the lead singer of UB40, Campbell, one of the defendants.' Thus, not only was the fact that Banks was the author in dispute, but also that she gave the lyrics to Khan. Regarding authorship, the court held that Banks composed the lyrics. ${ }^{10}$ But this is only the process of creation. If Banks had stopped at this, no consent could have been inferred. The court concluded based on the evidence that Banks gave the lyrics, typed on a piece of paper, to Khan. ${ }^{11}$ This act of giving the lyrics indicates Banks enabling the work to be used by Khan, and therefore represents the positive act. The court, of course, did not call it a positive act, but did identify the act, took evidence on it and concluded in fact, that Banks gave the song to Khan, disproving Khan's version.

In Brighton v Jones, ${ }^{12}$ Brighton, the claimant was going to direct a play called 'Stones In His Pockets', which Jones, the defendant, was going to write, for a production company Brighton owned. Apprehending that Jones had not started writing the script, Brighton wrote

\footnotetext{
8 [1996] EMLR 440.

9 ibid 443.

10 ibid 448.

11 ibid.

12 [2004] EWHC 1157 (Ch).
} 
a draft of the opening scene and sent it to Jones to 'kick-start' Jones's playwriting. ${ }^{13}$ Brighton's act of writing the opening scene alone would not have been sufficient to count towards her consent. Hence, the act of sending the draft is the positive act of concern here. The court stated that Brighton 'sent the script with an implied licence to use it', ${ }^{14}$ but this does not convey the proper sequence of events. It is the act of sending that gives rise to the implied licence. Separating the positive act thus shows how consent comes into play, and a licence based on it when other criteria (discussed below) are satisfied.

In case of musical works, as discussed in the three cases below, the positive act may lie in giving access to the sheet music, or the copyright owner's participation in a recording that amounts to the positive act. There is no discussion of the act of participation in these cases, as the copyright owner in each case admits to taking part in the recordings. The main issues in each case are the scope of the licence and its revocability, which are addressed later in this Chapter.

In Godfrey $v$ Lees, ${ }^{15}$ Godfrey, the claimant, was acquainted with the members of a band by name Barclay James Harvest, but was not part of the band himself. Godfrey participated in the rehearsals by sometimes playing the piano, arranging or conducting the orchestra, for the songs the band recorded or played in concerts. ${ }^{16}$ Among these, Godfrey's original contribution lay in his orchestral arrangement linking orchestral sequences and passages to the songs, ${ }^{17}$

\footnotetext{
13 ibid [21].

14 ibid [72].

15 [1995] EMLR 307.

16 ibid 315-6.

17 ibid 326-29.
} 
which was presumably in the form of sheet music. Thus, Godfrey giving access to his orchestral arrangement, whether in a recording or a live performance, is the positive act.

In Beckingham v Hodgens, ${ }^{18}$ the claimant Valentino was hired as a session violinist to record a song called 'Young At Heart'. Valentino composed the solo violin part in the song, during the rehearsals, or what is commonly known in the music industry as jamming sessions. ${ }^{19}$ Even if Valentino created the solo part, if he had not taken part in the recording, it would have been difficult to establish his consent. Therefore, the positive act is the taking part in the recording.

Similarly, in Fisher v Brooker, ${ }^{20}$ Fisher, the claimant, who joined the band Procol Harum, rehearsed with the band for the song 'Whiter Shade Of Pale', and composed an original organ solo that he played as a prelude and interlude to the song. ${ }^{21}$ In addition to rehearsing with the band, Fisher also played the organ in the recording session. The act of participating at the recording is the act that amounts to the positive act.

There is a common practice in the music industry for the session musicians to sign a consent form, such as the one signed by Valentino in Beckingham. ${ }^{22}$ The contents of the consent form are not clear from the decision in Beckingham, except that by signing the consent form Valentino gave consent for his 'performance' to be used in the recording. It appears therefore, that this is all the consent form was meant to do - consent to the recording of his live

\footnotetext{
18 [2002] EWHC 2143 (Ch).

19 ibid [5].

${ }^{20}$ [2006] EWHC 3239 (Ch).

21 ibid [32].

22 Beckingham (n 18) [55].
} 
performance at the studio, ${ }^{23}$ as opposed to the use of his original composition. A session musician is not expected to contribute to the composition of music, but only play the music composed by someone else. Where a session musician does compose a copyright work in his own right as in the case of Beckingham and Fisher, their performers' rights must be distinguished from their rights as the author of the music they create. The signing of the consent form is not the positive act of concern here, since it does not engage with the copyright in the composition.

The positive act changes not only with the nature of the work, but also the medium in which it is created. In the internet context, placing the work on the internet is the positive act, as will be discussed in Chapter VIII, section 1.1 below.

The positive act is by no means a complete grant of licence. It is only a part - albeit a significant part - of the conduct that conveys consent. For the act of consenting to complete, having enabled the use of the work, the copyright owner must stand back while the work is used, which takes us to the neutral act.

\subsection{The Neutral Act}

The neutral act follows the positive act closely, and is the other part of the conduct representing consent. The neutral act is the inaction of refraining from doing something which will alter the effect of the positive act. In all cases considered here, the neutral act is absolute. Courts provide discussion on this to different degrees, but identifying the facts making up the neutral act is necessary to make transparent the reason why an implied licence continues for the length of time that it does.

In Brighton, as explained above, Brighton had sent a draft opening script to Jones to kick-start Jones' playwriting, and that the act of sending the draft amounted to the positive act.

${ }^{23}$ CDPA, s 182. 
Brighton's inaction to stop Jones from using the draft is the neutral act of relevance here. By this neutral act, Brighton conveyed that she does not object to Jones using the draft in her playwriting. The inaction was absolute in that Jones could use the draft in any manner that was within Brighton's knowledge. Although the judge does not use the word inaction, he refers to the lack of an effort on Brighton's part to revoke the licence as the reason why the implied licence continued, allowing Jones to use the draft also in re-writing the play a couple of years later for another production house. ${ }^{24}$

The judge further pointed out that if Brighton had wished to limit the use of the draft opening script by Jones, she could have included a covering letter when sending it to Jones, laying down the restrictions placed on its use. ${ }^{25}$ This would have made the neutral act partial in that Brighton could have specified the actions she objects to, resulting in an express licence allowing only some of the consequences of the positive act to take effect. Had there been restrictions that the draft could only be used for a play with Brighton's production company, Jones may have chosen to ignore the draft altogether, in order to free her work of Brighton's contribution.

Also in Banks, Beckingham, Godfrey and Fisher, the neutral act was absolute. In none of these cases the copyright owner restricted the use of her copyright work. The neutral act in each of these cases conveyed that the copyright owner did not object to her copyright work being used. As explained in Chapter II above, so long as the neutral act continues, meaning so long as the copyright owner takes no action, the licence continues. The neutral act continued for 5 years in Brighton, 9 years in Beckingham, 14 years in Godfrey and 38 years in Fisher. The moment the neutral act changes to a negative act, i.e., the inaction changes to an action to stop

\footnotetext{
${ }^{24}$ Brighton (n 12) [73], [77].

25 ibid [76].
} 
the use of the copyright work, the bare licence is revoked. It might also happen in certain cases that the neutral act is relied on by the licensee to her detriment, leading to proprietary estoppel, preventing the copyright owner from revoking the licence. Revocability of bare licences is discussed in section 2 below.

The partial or absolute effect of the neutral act is demonstrated well in the internet context. When a person, having placed her work on the internet, leaves it there without terms of use, it is an absolute neutral act; when the content is placed with terms of use, it is a partial neutral act. ${ }^{26}$

For a copyright owner to decide how much of the effect of the positive act she wants to ensue, she must know the state of affairs she will bring about by her positive and neutral acts. The positive and the neutral act are therefore, inexorably linked to what the copyright owner knows about the surrounding circumstances, which brings us to the next section.

\subsection{The knowledge of the copyright owner}

No one can consent without knowing what one is consenting to. ${ }^{27} \mathrm{I}$ argue that an assessment of such knowledge should focus on the facts within the copyright owner's actual knowledge, even if such knowledge is objectively assessed. This is because, the imputation of knowledge is only possible if the relevant practice has become a custom. ${ }^{28}$ If no such custom exists, and the knowledge of the circumstances is unreasonably imputed to the copyright owner, the resulting consent and its ability to act as the basis for implying a licence both become weaker. I propose three aspects to assess the knowledge of the copyright owner - first, the realisation

\footnotetext{
${ }^{26}$ See Chapter VIII, section 1.2 below.

27 Simon Lee, 'Towards a Jurisprudence of Consent' in John Eekelaar and John Bell (eds), Oxford Essays in Jurisprudence Third Series (Clarendon Press 1987) 212.

${ }^{28}$ See Chapter V below.
} 
of the authorship of the work; secondly, the realisation that the work will be used gratuitously; and thirdly, the knowledge of the surrounding circumstances.

\subsubsection{Realisation of authorship of the work}

There are two aspects to this point - firstly, a person being an author as a matter of law; and secondly, the person realising that she is an author as a matter of fact. The following deals with each aspect.

\subsubsection{Authorship and joint authorship}

The author of a copyright work is its first owner. ${ }^{29}$ Chapter II above discussed that the exercise of the ownership powers is one of the sources for granting a copyright licence. Ownership connects a lawful licence with the owner. If such connection did not exist, there will be no difference between a person lawfully giving permission and a person authorising the use of certain content which she is herself not authorised to use (thereby infringing its copyright). For example, in Banks, if Banks gave a song to Khan that she did not write or had no rights to, we might still be able to speak of a positive act of handing the song and the neutral act of standing back when Khan used the song. But it will not give rise to a licence because she does not own the song, and cannot therefore, exercise the powers of ownership to grant a licence.

Many cases considered in this Chapter involve joint authorship, which ushers in its own challenges. A work of joint authorship is produced by the collaboration of two or more authors in which the contribution of one author is not distinct from that of the others. ${ }^{30}$ The

\footnotetext{
${ }^{29}$ CDPA, s 11(1). However, a copyright owner may not always be the author, but an assignee from the author. When an author as the first owner of copyright assigns her copyright interest, the assignee will have the same rights as the author in relation to the assigned interest. A common example is when the copyright owner assigns her copyright to a collecting society. Assignment is usually an arms-length transaction where both parties are likely to realise what is being assigned. The issues as to the realisation of the ownership of the copyright work arises more in the context of an author, as the case law shows, than in the context of an assignee.
}

${ }^{30}$ CDPA, s 10(1). 
CDPA states that where a copyright work is owned by more than one person jointly, any provision requiring of the licence of the copyright owner requires the licence of all of them. ${ }^{31}$ Therefore, the requirement of a licence of the copyright owner to avoid infringement, ${ }^{32}$ requires a licence of all the joint authors, if the work is of joint authorship. Such licence can be an express or an implied licence. Therefore, joint authorship must be established first, before the issue of implied licence can be addressed.

A detailed account as to when a person becomes eligible to be a joint author is outside the scope of this thesis. For our purposes, the rules of joint authorship can be summarised as follows: the collaborator must make some contribution towards the creation of the work; such contribution must be significant, but not necessarily to the same extent as others; but the contribution must be original. ${ }^{33}$ However, copyright rules of authorship in general and joint authorship in particular, are complex and contentious. It is not surprising therefore, that the copyright owner does not realise that her actions have given rise to a copyright work.

\subsubsection{Realisation of authorship}

The realisation of authorship matters because, even if a person is regarded an author as a matter of law, unless she realises that she is an author, she will be unable to have the required state of mind to consent for her work to be used. Courts do sometimes mention the copyright owner's lack of knowledge of copyright entitlement. However, they do not necessarily recognise it to be an impediment to the finding of implied licence.

\footnotetext{
${ }^{31} \mathrm{CDPA}, \mathrm{s} 173(2)$.

${ }^{32}$ For example, CDPA, s 16(2).

${ }^{33}$ Gillian Davies, Nicholas Caddick and Gwilym Harbottle, Copinger and Skone Janes on Copyright (17th edn, Sweet \& Maxwell 2016) para 4-47.
} 
A good example of the difficulties posed in this regard is Brighton. ${ }^{34}$ In this case, as stated above, Brighton was the director of a play which Jones was going to write. Brighton's first claim was for joint authorship based on her contribution to the changes to Jones' script during rehearsals, and the second claim was based on her authorship of the draft opening script that she sent to Jones. The judge observed that it had not occurred to Brighton to claim her joint authorship until she approached the court. But Brighton's lack of knowledge did not matter because the judge dismissed her claims of joint authorship. However, it is possible that Brighton did not articulate her authorship also in relation to her second claim, i.e., of the draft script she sent to Jones, until she sought legal advice. The judge does not acknowledge this in the judgment, although he records that Brighton had been 'hurt' by the way her 'contribution' to the play had not been recognised. ${ }^{35}$ Brighton sending the script was completely unsolicited, and Jones stated in her evidence that she did not need it. ${ }^{36}$ However, Jones used whatever she could of the draft, out of deference to Brighton, in creating the script for the play. ${ }^{37}$

It is difficult to conjecture exactly what Brighton thought was her relationship with the draft script she sent to Jones. Being the director of the play Jones was going to write, Brighton may have thought that she was sending some ideas, to which she may have felt a proprietary attachment, like most lay persons do, to their original ideas. This may explain why she felt that she had contributed to the play beyond her role as a director, for which she expected to be acknowledged. Although Brighton did not subjectively articulate clearly in terms of copyright, objectively assessed, she had a loose sense of proprietary attachment. However, this issue was

\footnotetext{
34 Brighton (n 12).

35 ibid [28].

36 ibid [21].

37 ibid [61].
} 
neither raised nor discussed in the judgment. The court only held that Brighton had impliedly licenced her work.

The issue is particularly troublesome in case of joint authorship. The plaintiff in many of the cases considered below, is in a creative collaboration with others, for example a music band. The plaintiff is normally a background musician or takes on a support role, as opposed to a lead role in the process of creation, and is normally unaware of the significance of her contribution towards creating the work.

In Barrett $v$ Universal Island Records $L t d{ }^{38}$ the claimants, Barrett brothers, were each a base guitarist and a percussionist with the well-known reggae musician, Bob Marley. ${ }^{39}$ Barrett brothers were not signatories to the key agreements entered into by Marley with the defendant record company (Island), and had always allowed Marley to deal with the business aspects of the band. ${ }^{40}$ The issue was whether Barrett brothers had impliedly licenced their copyright to Island by participating in the recording. Barrett brothers claimed that they did not realise that they were also entitled to copyright as joint authors when the songs were being created. ${ }^{41}$ The court held that they were not session musicians, ${ }^{42}$ as they were always part of the band, being paid by Marley during his lifetime, and from his estate after his death. ${ }^{43}$ They were also paid for record sales, ${ }^{44}$ and one of them was recognised as a co-author of some of the songs

\footnotetext{
38 [2006] EWHC 1009 (Ch).

39 ibid [18].

40 ibid [214], [229].

41 ibid [207].

42 ibid [259].

43 ibid [208].

44 ibid [60].
} 
recorded. ${ }^{45}$ The court therefore held that Barrett brothers may not have known as little about copyright entitlement as they claimed, ${ }^{46}$ and went on to conclude that Barrett brothers had impliedly licenced their copyright to Island.

In Godfrey, Godfrey was not a member of the band, but played piano for the band and arranged music for many of the songs. The court found that due to the 'free and easy' lifestyle they led and the informal nature of the relationship between the band members, it is unlikely that Godfrey or any member of the band realised at the time of recording that Godfrey could be entitled to copyright. ${ }^{47}$ However, Godfrey had got the band to acknowledge him on the albums as the 'resident musical director' or as the 'conductor and musical director'. ${ }^{48}$ In addition, Godfrey asserted that there was an agreement to share the profits with him, ${ }^{49}$ although the court found the evidence too lean to support a concluded agreement with the other members of the band. ${ }^{50}$ These facts revealed that Godfrey may have known his rights to some degree, even if he did not articulate it clearly as copyright.

Thus, the courts have generally tended to favour the view that the licensor does not need to articulate clearly that a copyright work has come into existence. It may be sufficient if the copyright owner has a sense of proprietary attachment to the work created. This could be as simple as knowingly creating something. Although the courts should require actual knowledge of copyright ownership, the courts have set the threshold of this knowledge very

\footnotetext{
45 ibid [208].

46 ibid [207].

${ }^{47}$ Godfrey (n 15) 330-31.

48 ibid 330.

49 ibid 322-24.

50 ibid 325 .
} 
low. It may not be entirely satisfactory from a theoretical viewpoint, as one might wish to insist on the full articulation of copyright, so that a state of mind necessary for consent can be decisively formed. However, there are practical considerations. A copyright owner can allege lack of articulation of her copyright entitlement, if only to defeat a licence being implied. In a joint authorship situation, if the other authors have gone ahead to licence the work of joint authorship, the lack of implied licence from one joint author who unscrupulously claims lack of knowledge of copyright ownership might have the effect of annulling those licences. Imposing a low threshold of knowledge of copyright entitlement, might avoid such opportunistic behaviour.

However, signalling that there is a need for such realisation of entitlement to copyright is essential, even if the threshold for such realisation is set low for pragmatic reasons. Otherwise, the copyright owner's conduct (positive and neutral act) could result in consequences which she had no knowledge of. Such knowledge is also important if there is a claim for proprietary estoppel, as we will see in section 2.2.2.1 below. Therefore, this component of the knowledge of the copyright owner must be assessed in all cases.

\subsubsection{Realisation of gratuitous nature}

This aspect of the licensor's knowledge is important because a bare licence by definition, is gratuitous. If a licence is in exchange for consideration, then it is not a bare licence, but a contractual licence. In some cases, a copyright owner might want to give away the work out of friendship. In some others, it may be that because the copyright owner does not realise that a copyright work has come into existence, she may not bargain for a fee. However, sometimes, even if she realises that a copyright work has come into existence, she might not have the bargaining power to negotiate. Sometimes, even if she negotiates, she might not be able to prove that a contract came into existence, as opposed to a bare licence. Therefore, the facts and circumstances of relevance here are the nature of the relationship (informal, friendly); 
whether the copyright owner gives her work upon request or unsolicited; whether a bargain was negotiated and can be proved.

Let us begin with the cases where the nature of the relationship itself points to the permission being gratuitous, such as a friend helping another friend. In Banks, as stated above, Banks had been acquainted with Khan, who told her that he had an opportunity to sing for the rock group UB40, and asked her to come up with some lyrics'. ${ }^{51}$ Banks' evidence also reveals that she considered Khan as someone who could 'barely read or write' English, and therefore, agreed to write a song for him. ${ }^{52}$ The other factors that may have acted on Banks' mind could be that Khan, being a machinist by profession, had been approached by a wellknown rock group to perform for them, recognising his singing talent. ${ }^{53}$ Banks might have wanted to 'help' a friend get a breakthrough into the world of pop music. These facts show that Banks meant to give permission to Khan to use the lyrics of her song, without anything else being evident from her words or action as to her expectation of any form of return.

Since the court does not sufficiently underscore the importance of the relationship, instead of Khan, suppose Campbell, the lead singer of UB40, had approached Banks to write the song. Then presumably due to the lack of friendship with Campbell, and knowing of Campbell's fame, Banks may have acted differently, and made it apparent that she was not giving the lyrics for free.

Banks is a case where the copyright owner granted a use privilege for free, out of friendship. However, a privilege could become gratuitous also in a commercial relationship, as it happened in Brighton, where circumstances other than the nature of relationship must be

\footnotetext{
51 Banks (n 8) 442-43.

52 ibid 443.

53 ibid 442-43.
} 
considered. In this case, as stated above, Brighton, was the director of a play that Jones was going to write. ${ }^{54}$ Brighton and Jones had worked together for many years on theatrical plays for various production houses. ${ }^{55}$ As stated above, apprehending that Jones was taking longer than expected to write the play, Brighton sent a draft to Jones consisting of about 11 pages of narrative of the opening scene, with a view to 'kick-start' Jones' writing of the play. ${ }^{56}$ Although Jones claimed that she did not need such help from Brighton, due to their long-standing collaboration in theatrical plays and since Brighton was going to direct the play, Jones did read the draft and used what she could. ${ }^{57}$ Therefore, Brighton had sent the draft opening script to Jones unsolicited, and Jones' evidence revealed that she had neither asked for it, nor had she needed it. ${ }^{58}$ Brighton did not dispute this in her evidence. Indeed, Brighton was not paid for writing the opening scene, based on which the court acknowledged the permission as being gratuitous.

It could also happen that both the relationship and the circumstances point to a possibility that the copyright owner could have bargained for her permission being in exchange for value. This normally happens when artists collaborate to produce a work of joint authorship. Normally, the part played by the chief composer or songwriter is uncontroversial. However, the part played by performers who bring in an instrumental backing to a song, or arrange the music for a song tends to be controversial. Their lack of confidence as to their contribution to the creative process reduces their bargaining power, particularly for the up and

\footnotetext{
${ }^{54}$ Brighton (n 12) [2], [12].

55 ibid [12]-[13].

56 ibid [21], [60].

57 ibid [61].

58 ibid [75].
} 
coming artists. Assuming joint authorship of these artists is proved, the question is whether they should be taken to have impliedly licensed their work gratuitously. ${ }^{59}$

One of the leading examples is Beckingham, where Valentino, the claimant, was hired as a session violinist to record a song. ${ }^{60}$ However, Valentino claimed that he had not merely performed music, but had composed the solo violin part in the song. ${ }^{61} \mathrm{He}$ further claimed that he had discussed with his manager the possibility of being regarded a co-author of the song, but was told that if he made such a claim 'he would get a reputation as a troublemaker when he was trying to make a career as a musician. ${ }^{62}$ With this knowledge, Valentino made no claim at that stage, making his permission gratuitous.

Similarly in Fisher, Fisher had composed the organ solo for a song that went on to acquire 'something approaching a cult status' according to the trial judge. ${ }^{63}$ However, when Fisher raised his claim for joint ownership in 1967 when the song had just been recorded, he was met with a rebuff. ${ }^{64}$ His evidence further reveals that he feared that if he persisted with the claim, he would be asked to 'say goodbye to a career in ... the number one pop group. ${ }^{65}$ With this knowledge, Fisher made no claim at that stage, making the permission gratuitous.

\footnotetext{
59 See generally, Richard Arnold, 'Reflections on “The Triumph of Music”: copyrights and performers' rights in Music' [2010] IPQ 153.

${ }^{60}$ Beckingham (n 18) [5].

61 ibid.

62 ibid [57]. This fact was further confirmed by the Court of Appeal, where Parker LJ noted that the advice Valentino had received was that 'his share of such royalties would be eaten up by legal costs and that to make a claim might affect his developing career as a session musician.’ [2003] EWCA Civ 143 [28].

${ }^{63}$ [2006] EWHC 3239 (Ch) [3]. This sentence was quoted again in his decision by Lord Neuberger before the House of Lords in Fisher v Brooker [2009] UKHL 41 (HL) [29].

${ }^{64}$ [2006] EWHC 3239 (Ch) [57].

65 [2009] UKHL 41 (HL) [35].
} 
In Godfrey, apart from claiming joint authorship, Godfrey also claimed that there was a common understanding and an express agreement that he would be given a share in the profits that the band earned. ${ }^{66}$ However, the court found that after leaving the band Godfrey had made no effort to claim joint ownership of the relevant songs, nor his share, except on two occasions as to which the evidence was too sparse to come to a sensible conclusion. ${ }^{67}$ The court found that Godfrey was neither able to prove the common understanding he claimed to have existed, nor the express agreement for sharing profits. ${ }^{68}$ Therefore, even if a copyright owner claims that he did not give unilateral consent, but instead made an offer, if there is insufficient evidence to show that it was treated as an offer, and was accepted on its terms, no contract can come into existence.

If, however, there are mutual undertakings as to the permission being in exchange for payment, and if no payment is made, then the mere fact of non-payment does not make the licence a bare licence. It is still enforced as a contractual licence, since the contract would have come into existence. The licensor will be able to sue for damages for non-performance of the contractual licence.

\subsubsection{Being paid as a performer as opposed to a joint-author}

The receipt of any payment at all by the copyright owner does not convert the bare licence into a contract. If the copyright owner was paid not in recognition as a co-author, but for the services rendered as a performer (session musician), then such consideration does not support the permission given to use the property, but only the rendering of services. The element of

\footnotetext{
${ }^{66}$ Godfrey (n 15) 311-12.

67 ibid 317-19.

68 ibid 322-25.
} 
originality distinguishes a service from a copyright work. The following cases illustrate this point.

In Beckingham, Valentino was in fact paid a sum of $f^{7}, 7$ for playing as a session musician. ${ }^{69}$ Hodgens, the defendant, had composed the song and had written a part of the background score too. To the extent that Valentino played the music composed by Hodgens, it represents the payment for the services rendered, and not for any original work created by Valentino. The service contract should be separated from the bare licence, even though both arise from Valentino's playing of the violin. There was a completed contract in relation to the services rendered so far as the non-original part of the music was concerned. In relation to the original part of the music and the property right in it, only a gratuitous licence arose, as Valentino had expressly stated to the defendants that he was not going to make a claim to be compensated. $^{70}$

In Godfrey, Godfrey too had been paid as a performer for his services. The evidence showed that the payment averaged about a few pounds a week and Godfrey had been paid $£ 100$ by the band's manager. ${ }^{71}$ As stated above, Godfrey was never part of the band. Only a part of his work for the band gained him copyright protection. The payment he received was only in exchange for the services he had rendered. It had been argued in this case that the amount paid to Godfrey was indeed sufficient compensation for a licence of his property rights in the works for which he had established himself to be a joint author. ${ }^{72}$ However, the judge rejected this and found that the evidence of such payment was 'too slender', and in any event

\footnotetext{
69 Beckingham (n 18) [55].

70 ibid [57].

${ }^{71}$ Godfrey (n 15) 316.

72 ibid 329.
} 
did not cover payment for Godfrey's contribution to the copyright works in question. ${ }^{73}$ Godfrey's inability to prove a concluded contract, together with the fact that no payment had been made for his share in copyright, made his licence gratuitous.

\subsubsection{Knowledge of the circumstances}

Implication is an ex post assessment of copyright infringement. Therefore, one may look at the alleged infringing acts of the defendant, and ascertain if based on the knowledge of the copyright owner as to the circumstances, the licensor could have authorised those acts. The knowledge of the circumstances includes the knowledge of the consequences of engaging in the positive and the neutral acts, and therefore, influences the use to which the copyright work may be put. In none of the cases discussed below have the courts come to the conclusion that the copyright owner implied a gift, because it was not within the copyright owner's knowledge that the defendant can exercise ownership rights over the copyright work when engaging in the positive and the neutral acts.

Banks is a good starting point because the licence was sought to be implied in noncommercial settings and implied gift was also at issue. The assessment here is of what Banks knew before engaging in the positive act of handing the paper with the song written on it. Like all other cases being considered here, there existed no agreement between Banks and Khan regarding the use of the lyrics or any compensation. ${ }^{74}$ There existed no relationship between Banks and Campbell, be it friendly or commercial. All Banks knew was that the song she wrote was meant to be sung by Khan for the band UB40. Let us see how this knowledge influenced the use to which the copyright work could be put.

\footnotetext{
73 ibid 330.

74 Banks (n 8) 449.
} 
Khan took the lyrics to Campbell and had the latter make some changes. Since Banks knew all along that the objective was to turn the lyrics she had given to Khan, to a song to be sung with UB40, Harman J held that if she had been asked whether changes could be made to suit the band's music and singing styles, she would have readily agreed. ${ }^{75}$ Therefore, Khan had the authorisation to adapt the lyrics into a song. When Khan gave lyrics to Campbell, Khan also sublicensed Campbell the right to adapt the lyrics into a song. Could Banks' licence to adapt to Khan be sub-licenced? Collaboration is in the very nature of the way a band functions, and therefore this should have been within Banks' knowledge. Although Harman J did not articulate it in these terms, this appears to be the basis for Campbell being able to exercise the right to adapt the lyrics.

Further, Khan assigned the lyrics in the song to UB40, for which he received a consideration of $£ 10,000$. Khan's version of the facts was that he had written the lyrics himself, and that he had found the lyrics Banks gave him not suitable. ${ }^{76}$ Once Khan sold the rights to the lyrics to UB40, UB40 went ahead to perform the song without Khan.

The first question is whether Banks assigned her copyright in the lyrics, and did not licence it; and secondly, if she granted a licence, did it extend to someone else performing the lyrics, and not Khan. Harman J concluded that Banks had not intended, nor could it be implied that she was making an outright gift of copyright in the lyrics, on the basis that no 'reasonable bystander' could regard the handing over of the lyrics as an assignment. ${ }^{77}$ There is no further discussion as to why a reasonable bystander would not regard it as an assignment. The answer to this question may lie in the assessment of Banks' own knowledge - it simply did not extend

\footnotetext{
75 ibid 450.

${ }^{76}$ Note that there was no issue of whether Banks assigned or licensed her lyrics, as Khan simply claimed that Banks never wrote the lyrics.

77 Banks (n 8) 450.
} 
to a possibility of she not having any rights over the lyrics in the future. Therefore, it was only a licence.

Harman J held further that when Banks gave the piece of paper with lyrics on it to Khan, it was only for Khan's personal benefit to sing with UB40. At that time, Banks did not have in her mind, nor did Khan indicate the possibility, that the lyrics could be used for a different person singing with UB40. As such, the implied licence only extended to Khan being able to perform the lyrics, and not to sub-licence the permission to perform to anyone else. Banks had no communication with Campbell. As such, there was no question of her granting an implied licence to him or UB40, which Haman J did recognise. ${ }^{78}$ As such, UB40 had no rights to perform the lyrics or exploit them in any other manner, either by way of a license from Banks, a sub-licence from Khan or an assignment from Khan.

If the relationship between a licensor and a licensee is commercial or in their professional capacity, the implied licence in some cases can be sub-licensed to those other than the original parties to the implied licence. In Banks, since the relationship was informal and friendly, Khan was not able to use the lyrics if he was not himself performing the song with UB40. On the other hand, the result was different in Brighton since Jones and Brighton were in a commercial relationship.

In Brighton, Brighton sent the draft opening script to Jones to use it in her writing of the play. ${ }^{79}$ Brighton had claimed that there was a separate copyright that she owned in the draft, which was incorporated in Jones' script of the play. ${ }^{80}$ Brighton accepted that she not only knew that the draft could be used by Jones, but it was indeed the purpose of her sending

\footnotetext{
78 ibid 450-51.

${ }^{79}$ Brighton (n 12) [21].

80 ibid [4].
} 
it to Jones. ${ }^{81}$ The original version of the play was staged in 1996. However, Jones rewrote the play in 1999 and released it through a different production company and a different director, which became a big success throughout the English-speaking world. ${ }^{82}$ Brighton claimed that Jones had no implied licence from her to use the draft to rewrite the 1999 script, nor to exploit the 1999 script with other production companies. ${ }^{83}$

To assess Brighton's knowledge, we must examine the relationship Brighton and Jones had under the commissioning agreement. Oddly, Brighton revealed in her evidence that she was not aware that written agreements were required for Doublejoint to engage Jones, or indeed that one was actually entered into. ${ }^{84}$ But her subjective lack of knowledge (or refusal to get involved) did not affect an objective conclusion that as the owner Doublejoint, Brighton should have known that these agreements had been entered into, as the discussion below will reveal.

Under the agreement, Jones was required to stage the play with Brighton's production company (Doublejoint) for nine months. ${ }^{85}$ Jones understood this, rightly according to Park J, to mean that she was a 'free agent' to do as she pleased with the play script after this period. ${ }^{86}$ In addition, the commissioning agreement between Jones and Doublejoint (Brighton's production company) stated that if Jones chose to stage the play with any other production

\footnotetext{
81 ibid [4], [69].

82 ibid [26].

83 ibid [5], [72].

84 ibid [18].

85 ibid [16(ii)].

86 ibid [25].
} 
company after Doublejoint, she had to acknowledge Doublejoint as the original production company and had to share a certain percentage of the profits for a period of five years. ${ }^{87}$

These clauses in the agreement go to show that Doublejoint, and hence Brighton, had envisaged Jones staging the play for other production companies. Both Brighton and Jones knew that Jones was not exclusively tied either to Brighton or to Doublejoint indefinitely. Park J, therefore, rejected Brighton's claim on the basis that the implied licence granted by Brighton to prepare the 1996 version of the script was still in existence and continued until Jones wrote the 1999 script. ${ }^{88}$ Therefore, Brighton impliedly licensed Jones to adapt the dramatic work in the draft into a play, and to exploit the play in whatever manner Jones pleased, including having the play performed in public. This right to publicly perform the play incorporating the script could be sub-licensed, given the provisions of the commissioning agreement.

In Brighton, Jones had the benefit of the express terms of the commissioning agreement in order to assess what ought to have been in Brighton's knowledge. In certain other cases, for examples when musicians collaborate in a band, either as session musicians or as members of the band, there may be no express terms to rely on. The mere taking part in a recording knowing that a record will be produced of it, or giving access to sheet music knowing that it will be performed, appears to make the implied licence they grant extend to all reasonable exploitation of the work. This appears to be the case in Beckingham, Godfrey and Fisher. In Beckingham, the judge noted that there was an implied gratuitous licence for Mr Hodgens to exploit the copyright in "the Work". ${ }^{99}$ Similarly, in Godfrey, the judge simply said the implied

\footnotetext{
87 ibid [16(iii)-(iv)].

88 ibid [72].

89 Beckingham (n 18) [64].
} 
licence was granted for the 'exploitation' of the work. ${ }^{90}$ Likewise in Fisher, Blackbourne J also held that Fisher had granted gratuitous implied licence to exploit the work at issue. ${ }^{91}$

The meaning of the term 'exploitation' is not clear. In these cases, exploitation could mean deriving income from all reasonable uses of the recording, such as mechanical rights (i.e., reproducing the record to make copies for sale), public performance of the record, and live public performance of the songs. ${ }^{92}$ But it might not include making an audio-visual music video of the song, unless the copyright owners also participated in the making of such music video. Within my framework, however, I argue that exploitation can only mean what is within the actual knowledge of the copyright owner. The court should not push the element of knowledge to what ought to have been within the reasonable contemplation of the copyright owner, such as technological innovation.

This issue was briefly discussed in Barrett. The judge found that at the time when the recordings were made, the chief means of reproduction were vinyl records and cassettes. ${ }^{93}$ The judge also found that the agreement which Marley had signed in 1974 envisaged that the recordings could be reproduced by 'other means'. ${ }^{94}$ Barrett brothers had allowed Marley to enter into all business transactions, and had accepted whatever amount he paid without objection. Barrett brothers were held not to be parties to this agreement, ${ }^{95}$ but it appears from the judgment that Barrett brothers were imputed with the knowledge of what was in the

\footnotetext{
${ }^{90}$ Godfrey (n 15) 331.

${ }^{91}$ [2006] EWHC 3239 (Ch) [94].

${ }^{92}$ See Barrett (n 38) [37] for a summary of the principal sources of income of the artists in that case.

93 ibid [360].

94 ibid.

95 ibid [229].
} 
agreement. They were held to have impliedly licensed their copyright to the recording company. ${ }^{96}$ Accordingly, the court held that this includes reproducing by means of CDs and DVDs, 'as a more technologically advanced means of reproducing the same work in essentially the same form', and thus did not require a fresh licence. ${ }^{97}$

This holding is problematic. Even if Barrett brothers were imputed with the knowledge of the agreement, the agreement itself was signed in 1974 - a time when CDs and DVDs did not exist. Further, CDs and DVDs do not essentially reproduce the songs in 'the same form', as the judge claims. As technological advancements, they transform an analogue copy of the recording into a digital copy. A digital copy can easily be uploaded on the internet, reaching an unprecedented number of audience, potentially also increasing the risk of unauthorised copying to an unprecedented degree. It is unreasonable to hold that merely because the agreement provided for the recordings to be reproduced by other means, Barrett brothers had within their knowledge or contemplation in 1974, such a drastically different technology posing such different challenges and risks.

On the view taken here, the scope of an implied licence cannot extend to technologically more advanced media and media not yet invented, since the copyright owner's knowledge may not extend to these technologies at the time of entering into the contract. A more nuanced assessment of the knowledge of the copyright owner is required here, for consent to be a legitimate basis for implying a licence. This issue is discussed again in relation to consent-based implied contractual licences below. ${ }^{98}$

\footnotetext{
${ }^{96} \mathrm{ibid}$ [360]. This case is not discussed in detail here since the implied licence was not gratuitous but contractual, as Barrett brothers had been paid as co-authors.

${ }^{97}$ ibid.

${ }^{98}$ See Chapter IV, section 2.2.2.3 below.
} 


\section{Revocation of bare licences}

Revocation is different from termination. Any contract can be terminated at will, but consequences follow for the person terminating, if such termination is not according to the terms of the contract. However, revocation is an eventuality without such consequences for the person revoking. In this sense, we can only speak of revocation in relation to bare licences. As discussed in Chapter II above, to permit the use of one's property is one of the incidents of ownership. ${ }^{99}$ Such power can be exercised by the owner at will. When such permission is granted unilaterally, the copyright owner is not obliged to ensure the continuance of the permission. There is no duty on part of the copyright owner to continue the permission granted. ${ }^{100}$ As such, the copyright owner is free to take back what had been given, upon giving reasonable notice.

Revoking an implied licence in this context means that the implied licence in gratuitous form comes to an end, and therefore all uses of the work should be stopped. If the licensee intends to use the work beyond revocation, she must negotiate with the licensor for a new licence. If the negotiations are successful, a contractual licence will come into existence in place of a gratuitous licence. In this sense, the revocation of the bare licence can only operate prospectively.

\subsection{Act of revocation}

As stated above, turning the neutral act into a negative act results in the revocation of a bare licence. In each case discussed above, the licensor at some point had tried to revoke the

\footnotetext{
${ }^{99}$ See Chapter II, section 2.1.1 above; see also A M Honoré, 'Ownership' in Anthony Gordon Guest (ed), Oxford Essays in Jurisprudence First Series (Clarendon Press, 1961) 107, 112-24.

100 See Chapter II, section 2.3.1 above.
} 
permission given. The act of revocation typically takes the form of a letter before action, demanding the cessation of the use of the copyright work. If there is no letter before action, the fact of the licensor approaching the court revokes the bare licence. However, in some cases it might take the form of a verbal exchange well before commencing such action, which might be factually difficult to prove.

Beckingham is one such case where the date of revocation was controversial. In this case, the song with Valentino's violin piece was a reasonable success when it was released, but a bigger success later in $1993 .{ }^{101}$ The trial judge concluded on the facts that in 1993 , there was a conversation between Valentino and Hodgens, where Hodgens had told Valentino that he would 'see him alright'. Valentino had replied saying that if he did not do so, he would 'go to law this time'. Upon Valentino's further enquiries thereafter, Hodgens responded that he had not yet received any royalties. ${ }^{102}$

There are several points for consideration here. Firstly, once the defendant establishes an implied licence, the burden shifts to the claimant/copyright owner to prove that it was revoked. Secondly, the colloquial usage - 'see him alright' or 'go to law' are informal expressions which must be considered in the context in which they were spoken. Thirdly, if the licensee wants to challenge revocation and put forward her own version of events, the burden shifts back to her to prove her claim, and often the assessment tends to be the words of claimant against those of the defendant. That is indeed what happened in Beckingham, where at the appellate stage it was argued unsuccessfully, that the trial judge came to an incorrect conclusion that Valentino's version was truthful. ${ }^{103}$

\footnotetext{
101 Beckingham (n 18) [59].

102 ibid.

103 [2003] EWCA Civ 143 [17], [19].
} 
In most other cases, the act of revocation was largely uncontroversial. In Banks the claimant's approach to the court revoked the licence. In Brighton, ${ }^{104}$ it was the letter before action, as also in Fisher ${ }^{105}$ In Godfrey, Godfrey also issued a letter before action in an attempt to revoke any implied licence he may have granted. ${ }^{106}$ However, for the reasons I discuss below, the court held that the implied licence was not revocable, which brings us to the next issue.

\subsection{Irrevocability: Proprietary Estoppel}

A licence continues so long as the neutral act continues. While the neutral act continues, the licensee might change her position relying on the continuation of the neutral act, such that when the neutral act stops and the act of revocation begins, the licensee claims to suffer a detriment. This might give rise to proprietary estoppel, preventing the copyright owner from revoking the bare licence. This means that the conduct on part of the copyright owner that the licensee relies on is simply standing by, when the licensee continues to use the copyright work. However, we will see in the discussion below, that the courts have not given sufficient recognition to the conduct of the copyright owner.

When estoppel is claimed in a bare copyright licence context, it results in the copyright owner's loss of the ability to deal with the copyright work. In Hohfeldian sense, the power of the copyright owner to freely grant and revoke a permission transforms to a disability, giving rise to a corresponding immunity to the licensee from revocation, due to a set of new operative facts. ${ }^{107}$ As we have noted, operative facts are those that change jural relations, either to create

\footnotetext{
104 A letter before action dated 7 November 2001 revoked the gratuitous licence. Brighton (n 12) [73].

105 [2009] UKHL 41 [45].

106 Godfrey (n 15) 319-21.

${ }^{107}$ For jural correlatives and opposites, see Hohfeld (n 2) 30.
} 
a new relation, or to extinguish an old one, or to perform both simultaneously. ${ }^{108}$ Finding these operative facts is the challenge in these cases, given the diversity of circumstances in which proprietary estoppel can be claimed.

Estoppel by acquiescence can also arise in a contractual copyright licence, especially where a copyright owner does not insist on a strict compliance with the terms of the contractual licence. ${ }^{109}$ Since the focus here is the use of proprietary estoppel to render a bare licence irrevocable, the cases on contractual licences are not discussed here.

The doctrine of proprietary estoppel traces its origin to land law. Copyright cases that have applied proprietary estoppel have sometimes expressly and sometimes tacitly relied on the principles of land law. ${ }^{110}$ It is essential, therefore, to understand how proprietary estoppel has evolved under land law, even if these cases have not arisen in the context of licences. The effort will be to ascertain with a degree of precision, the requirements of proprietary estoppel in land law, so that the corresponding requirements in the copyright context can be ascertained.

\subsubsection{Proprietary estoppel in land law}

It is rightly claimed that '[T]here is no definition of proprietary estoppel that is both comprehensive and uncontroversial (and many attempts at one have been neither)'. ${ }^{111}$ Broadly stated, the objective of proprietary estoppel is to promote conscientiousness in dealings in

\footnotetext{
108 ibid 16, 25

${ }^{109}$ See for example, Film Investors Overseas Services SAv The Home Video Channel Limited [1997] EMLR 347, a case involving a contractual licence to broadcast certain films. See Chapter IV, section 2.2.2.2 below for further discussion.

110 While Godfrey (n 15) refers to land law authorities on estoppel, Brighton (n 12) does not.

111 Simon Gardner and Emily McKenzie, An Introduction to Land Law (4th edn, Hart Publishing 2015) 143.
} 
land. ${ }^{112}$ Rights are created in land in an informal way based on an expectation of 'proprietary entitlement', ${ }^{113}$ since these rights do not arise from the property owner's intentional transfer of a property interest, nor is there a contract or formalities to that effect. ${ }^{114} \mathrm{~A}$ property interest comes into existence in order to protect the estoppel claimant ${ }^{115}$ from the detriment that might result from her reliance on a commitment made to her by the property owner. ${ }^{116}$ The conduct on part of the estoppel claimant is therefore, to act in reliance of a commitment made to her to her detriment. However, what exactly is the conduct required on part of the property owner that would induce the claimant's detrimental reliance?

The answer to this question is anything but certain. One may notice a wide variety of conduct on part of the property owner inducing detrimental reliance, ranging from standing by and taking no action, to an active and repeated promise of future conduct. But the courts have dealt with these cases by unifying the conduct under a single formula, which belies the diversity of such conduct, and brings little clarity. In an effort to unpack this diversity, some scholars suggest that different strands of proprietary estoppel be identified, namely, acquiescence, representation and promise. ${ }^{117}$ This classification is beneficial also to copyright law, as I will discuss below.

\footnotetext{
112 Kevin Gray and Susan Francis Gray, Elements of Land Law (5 $5^{\text {th }}$ edn, OUP 2009) para 9.2.2.

113 ibid para 9.2.1. However, it is possible that sometimes, instead of a proprietary interest, the court grants a monetary compensation to the person successfully claiming proprietary estoppel. Charles Harpum, Stuart Bridge and Martin Dixon, Megarry and Wade The Law of Real Property (8 ${ }^{\text {th }}$ edn, Sweet \& Maxwell 2012) para 16-001. See also, Jennings v Rice [2002] EWCA Civ 159.

114 Ben McFarlane, The Structure of Property law (Hart Publishing 2008) 445.

115 In land law, it is normally the claimant who asserts proprietary estoppel, and in the copyright cases discussed here, it is asserted by the defendant to deny infringement. However, it is conceivable for proprietary estoppel to be claimed by the claimant in an action for a declaration of non-infringement.

${ }^{116}$ I use the term property owner as a short-hand for the holder of a freehold or a leasehold title.

117 Ben McFarlane, The Law of Proprietary Estoppel (OUP 2014) paras [1.03], [1.05], [1.24]-[1.27].
} 
I discuss the paradigm case under each strand below. I demonstrate that with each new strand being introduced, the courts reformulated the requirements for proprietary estoppel in such a way as to take away the nuance identified by the previous approach, especially when defining the property owner's conduct.

\subsubsection{Acquiescence}

Acquiescence requires the claimant to have suffered a detriment based on her reliance on the property owner simply 'standing by'. Judges have sometimes held that there is no difference between acquiescence and proprietary estoppel. ${ }^{118} \mathrm{I}$ argue that acquiescence is one of the strands of proprietary estoppel, as explained below.

Arguably, one of the first attempts at identifying in detail the conduct of the property owner inducing detrimental reliance was made in Wilmott $v$ Barber. ${ }^{119}$ In this case, Barber, the first defendant had a lease over certain land, the terms of which barred him from assigning or sub-letting the land without the consent of his landlord, the second defendant, Bowyer. Without seeking Bowyer's consent, Barber granted a sublease to Willmott, the claimant, together with an option to purchase the remaining term on Barber's tenancy. Bowyer claimed that he was unaware that his consent was required for the sublease. ${ }^{120}$ Willmott went ahead and made improvements to the land, allegedly with the knowledge of Bowyer. While Willmott was doing so, Barber surrendered his lease and entered into a new lease with Bowyer for a fresh term, which also required Bowyer's consent for assigning and subletting the property. ${ }^{121}$

\footnotetext{
118 Fisher v Brooker [2008] EWCA Civ 287 [55]. The House of Lords said that acquiescence adds nothing to proprietary estoppel. [2009] UKHL 41 [62] (per Lord Neuberger).

119 (1880) 15 Ch D 96, 105-6. Some scholars take it back even further to Ramsden v Dyson (1866) LR 1 HL 129.

${ }^{120}$ Willmott (n 119) 97-98.

121 ibid 98.
} 
This time, Bowyer appears to have noticed this term in the agreement. A few years later, when Willmott tried to exercise his option to purchase Barber's remaining term of tenancy, Bowyer refused consent. The question was whether Bowyer had acquiesced in Willmott's expenditure, and therefore could not refuse consent. ${ }^{122}$ In this context, Fry J identified the following five elements which must be present before acquiescence can be found. ${ }^{123}$

- firstly, a mistake on part of the claimant as to her legal rights;

- $\quad$ secondly, the property owner must know of the claimant's mistaken belief of her rights;

- thirdly, the property owner must know of the existence of her own right which is inconsistent with the right claimed by the claimant;

- fourthly, the claimant must have expended some money or must have done some act on the faith of her mistaken belief; and

- lastly, the property owner must have encouraged the claimant in her expenditure of money or in other acts which she has done, either directly or by abstaining from asserting the property owner's right.

Applying these to the facts, Fry J found a mistaken belief on Willmott's part, but did not find that Bowyer had the knowledge of Willmott's mistake or Bowyer's own right to consent to the assignment of the lease to Willmott. Fry J went on to hold that the expenditure that Willmott incurred was not on the faith of his option to purchase. Fry J, therefore, held that Bowyer had not acquiesced in Willmott's conduct of accepting the assignment of the lease and in incurring expenditure.

\footnotetext{
122 ibid 99.

123 ibid 105-6.
} 
For our purposes, the enquiry is - what should have been Bowyer's behaviour for him to lose his right to consent to Barber assigning the lease to Willmott? Bowyer had only stood by, while Willmott expended money on improvements. For this inaction alone to be sufficient, Bowyer needed to know not only that Willmott was under a mistake that he could take the sublease and the assignment of the remainder of the lease, but also of Bowyer's own right to refuse consent to such sub-lease and assignment. Bowyer knew of neither. Such lack of knowledge is likely to have prompted Bowyer to stand by, while Barber sub-let the premises to Willmott and Willmott made improvements to the land. Therefore, before depriving Bowyer of his right to refuse consent due to his inaction, the court found it reasonable to enquire why there was such an inaction. Subsequent cases also confirmed that the relevant time when the defendant is required to have knowledge of his rights is when the claimant begins to act on the faith of the mistaken belief to her detriment. ${ }^{124}$

Not every case where proprietary estoppel is claimed is a case of the defendant's inaction. If there is some action on part of the property owner which the claimant can rely on, a detailed analysis of the state of mind of the property owner may not be necessary. This is because a person is presumed to intend the natural consequences of her actions, and those are the actions that the claimant relies on. There may be no mistake by either party. The requirements that fit an active property owner, rather than a passive one must, therefore, be distinguished. This leads us to the next section, namely representation.

\subsubsection{Representation and the role of unconscionability}

Representation refers to an action (as opposed to standing by in acquiescence) that asserts a

124 Kammins Ballrooms Co Ltd v Zenith Investment (Torquay) Ltd [1971] AC 850, 884-85 (HL) (per Lord Diplock). 
state of affairs. Taylors Fashions Ltd v Liverpool Victoria Trustees Co Ltd ${ }^{125}$ marks the move away from acquiescence in Willmott towards another standard, namely that of representation. Here, the property owner had granted a long lease to the claimant, with an option to renew it at the end of the lease. However, the option to renew was not registered. Neither party to the suit knew about this requirement. ${ }^{126}$ The claimants argued that the five elements in Willmott did not provide the appropriate criteria to establish proprietary estoppel in this case because Willmott requires a unilateral mistake on part of the claimant. But in this case, the parties were under a bilateral mistake that no registration of the option to renew was required. The defendant claimed that Willmott applied, and in particular, that the requirement of the defendant's knowledge of his own rights was not satisfied. ${ }^{127}$

Oliver J accepted that Willmott could apply to certain specific cases 'where all that has happened is that the party alleged to be estopped has stood by without protest while his rights have been infringed'. ${ }^{128} \mathrm{He}$ further opined that in case of mere passivity, it is readily intelligible that there must be shown a duty to speak, protest or interfere, which cannot normally arise in the absence of knowledge or at least a suspicion of the true position. He went on to say that acquiescence or encouragement could take several forms - from active encouragement to standing by in silence while one party unwittingly infringes another's legal rights. ${ }^{129}$ This meant that proprietary estoppel could arise despite the absence of the unilateral mistake and the knowledge of the property owner of her own rights, if the property owner had 'acted' in such a way as to encourage the claimant to act on it. With this, Oliver J appeared to be drawing a

\footnotetext{
125 [1982] QB 133.

126 ibid 138.

127 ibid $147-48$.

128 ibid 147.

129 ibid 148.
} 
distinction between the two strands of estoppel, one drawn from acquiescence as in Willmott, and another based on representation. If he had stopped here, it may have brought some clarity. But he noted: ${ }^{130}$

[T] he (...) principle, whether you call it proprietary estoppel, estoppel by acquiescence or estoppel by encouragement is really immaterial - requires a very much broader approach which is directed rather at ascertaining whether, in particular individual circumstances, it would be unconscionable for a party to be permitted to deny that which, knowingly, or unknowingly, he has allowed or encouraged another to assume to his detriment, than to inquiring whether the circumstances can be fitted within the confines of some preconceived formula serving as a universal yardstick for every form of unconscionable behaviour.

Having warned against using universal yardstick of the 'formula' in Willmott, Oliver J did exactly that - to bring all forms of conduct under one yardstick of unconscionability.

However, Oliver J did not fully explain why Willmott could not apply to cases like Taylors. It is because, the first and the second elements (claimant's unilateral mistake as to her rights and the property owner's knowledge of such mistake) do not apply to this case because Taylors did not present a case of acquiescence. It was not a case where the property owner simply stood by and watched while the claimants incurred all the expenses. It was a case where the property owner made a very specific representation in the lease agreement by offering an option to renew, which the property owner intended the claimant to rely on. The claimant being also a party to the lease agreement unsurprisingly, did rely on it. This essentially means that there is no room for any mistake as far as the rights and obligations of the parties were concerned. The lack of formality or registration only made the obligation to honour the option to renew a contractual, as opposed to a property right. As such, the claimant's and the property owner's bilateral mistake that no registration was required, did not affect their understanding in relation to the mutually agreed rights and obligations. The third Willmott rule that the 
property owner must know his own right being incompatible with that of the claimant's, did not apply either, because the property owner had no right inconsistent with that of the claimants', which the property owner needed to be aware of. Therefore, Taylors was a case of a representation by the property owner, which could not have been dealt with by the acquiescence approach.

Taylors had a tremendous impact on the cases that followed. Subsequent decisions that relied on Taylors had the effect of firstly, underplaying the importance of Willmott. As Taylors ushered in an additional strand of proprietary estoppel, Willmott came to be regarded only as a historical reference, and not as a separate strand that might still have relevance under certain circumstances. Secondly, Taylors was interpreted as requiring only a general enquiry on unconscionability. ${ }^{131}$ Even if courts believed that unconscionability is broad enough to capture factors not specifically addressed by the traditional ingredients of proprietary estoppel, scholars have questioned unconscionability as a sufficiently viable and objective standard. ${ }^{132}$ Indeed, this will be evident in our discussion of Godfrey below.

\subsubsection{Promise/Assurance}

Proprietary estoppel took a new turn when it was not acquiescence as to a mistaken belief, nor a representation as to an existing state of affairs, but a promise of a future conduct by the property owner that was held to give rise to a detrimental reliance. A landmark case in this regard was Thorner $v$ Major, ${ }^{133}$ where the claimant, a taciturn farmer spent over thirty years working on his uncle's land without any wages, relying on a verbal promise made to him by

\footnotetext{
${ }^{131}$ Habib Bank Ltd v Habib Bank. AG Zurich [1981] 1 WLR 1265, 1285.
}

132 Mischa Balen and Christopher Knowles, 'Failure to estop: rationalising proprietary estoppel using failure of basis' [2011] Conv 176, 180; McFarlane, Structure of Property Law (n 114) 456.

133 [2009] UKHL 18. 
his uncle that the uncle would bequeath that land to him upon the uncle's death. The court held that for proprietary estoppel to be established, the three ingredients below should be satisfied, namely: ${ }^{134}$

(i) a representation or assurance made to a person;

(ii) reliance on it by that person; and

(iii) detriment to that person in consequence of his (reasonable) reliance.

Thorner did not address the role of unconscionability specifically, but cited with approval a previous authority which had held that an assessment of unconscionability cannot replace the requirement for specific ingredients like detrimental reliance. ${ }^{135}$

Thorner was not a case of the property owner standing by and watching while the claimant developed an expectation of proprietary interest, but was of a promise of future conduct. The promise or the assurance strand would have been less relevant for our purposes if not for Lord Walker's statement that acquiescence or standing by cases also count as assurances, if one were to analyse all cases on proprietary estoppel under the above criteria. ${ }^{136}$ All the nuance that had been identified by Willmott was merged in this one ingredient of assurance. With this identification of the requirements of proprietary estoppel, an enquiry into the state of mind of the property owner was rendered unnecessary, so long as there is detrimental reliance, even if all that the property owner had done was to simply stand by.

\subsubsection{Proprietary estoppel in copyright cases}

In land law, it is said that in its very origin, the doctrine of proprietary estoppel was

\footnotetext{
134 ibid [29].

${ }^{135}$ Cobb v Yeoman's Row Management Ltd [2008] UKHL 55 [59] (per Lord Walker).

136 Thorner (n 133) [55].
} 
conceptualised in order to correct reliance loss, ${ }^{137}$ and the belief is that the parties who rely on the conduct of a property owner need protection. The roles are reversed in many copyright cases - it is not the person relying on copyright owner's conduct, but the copyright owner herself who might need protection. Given the evident lack of bargaining power of the copyright owners like Fisher, Godfrey and Valentino as reflected in section 1.3.2 above, it must be considered whether the lead singers and songwriters in a band (who are estoppel claimants) should be protected from reliance loss, or copyright owners like Fisher, Godfrey and Valentino against the highhanded treatment of the estoppel claimants. This perspective underlies the discussion below.

The above discussion on land law shows that proprietary estoppel arises under diverse circumstances, and yet the courts have supported a move towards unifying the requirements and losing nuance, especially in relation to the property owner's conduct. We will see below that copyright cases present scenarios where there are mistakes as to rights of the parties similar to Willmott. It might be that land law does not need the level of nuance provided in Willmott, particularly in relation to the property owner's realisation of her own rights. Indeed, if Willmott were to be decided today, Bowyer will not be able to assert that he was unaware of his rights in an agreement he had himself signed. The transactions in land have become more sophisticated over the years and more transparent due to the formality requirements, and the registration system. Those with an interest in land are also more likely to seek legal advice, and less likely to be mistaken about their rights. None of these is necessarily true for copyright. It is still common for a person deeply engaged in a creative process not to realise her entitlement to copyright (like in Brighton). Given the complicated and unintuitive nature of rules of originality and joint authorship, it is unsurprising that a person whose only occupation is art,

137 Gardner and McKenzie (n 111) 159. 
is unaware of or is mistaken about these rules. Even if a person becomes aware of these rules, she might not be able to dispel mistaken beliefs without approaching a court. Therefore, losing nuance in the assessment of proprietary estoppel in copyright cases could lead to unfair results.

For these reasons, even if Willmott may have become less relevant in land law, I propose to resurrect it for copyright cases. More than in land law, it matters in copyright law that the acquiescence strand exists separately from the representation and promise strands.

\subsubsection{The different approaches}

I distil the land law principles of proprietary estoppel as they apply to copyright cases:

- Thorner approach: Regardless of whether there is an action or an inaction on part of the copyright owner, it will be regarded as a representation or an assurance, and no further assessment of the copyright owner's state of mind is carried out. Upon an overall assessment of unconscionability, if there is detrimental reliance on such representation or assurance, proprietary estoppel is established.

- Taylors approach: An action amounting to a representation, and detrimental reliance on such representation is normally required, and there is no need to assess the copyright owner's state of mind. However, if upon an overall assessment, the copyright owner's assertion of his rights is unconscionable, proprietary estoppel is established.

- Willmott approach: If there is an inaction on the copyright owner's part, then an assessment of his state of mind needs to be carried out according to Willmott. If there is detrimental reliance on such inaction, proprietary estoppel is established.

Let us analyse each requirement in relation to copyright cases.

What is required of the copyright owner to induce reliance

The discussion in section 1 above reveals that the conduct the copyright owner engages in 
when the bare licence is implied is the positive act and the neutral act. Thus, by the time a proprietary estoppel claim is raised against the copyright owner, she has engaged in both an action and an inaction. The first question before us is whether approaching proprietary estoppel based on her action as a copyright owner in the Thorner or the Taylors approach above is a fairer assessment, or on her inaction in the Thorner or the Willmott approach? The discussion in section 1 also revealed that the positive and the neutral acts do not exist in vacuum, and that the knowledge of the copyright owner must be considered. Therefore, the second question is whether the knowledge of the copyright owner should be assessed also for proprietary estoppel. If one follows the Thorner or the Taylors approach above, then the knowledge of the copyright owner is disregarded. On the other hand, if one follows the Willmott approach above, then the knowledge of the copyright owner is also considered.

The question whether the copyright owner's action or inaction must be considered, can be illustrated by using Godfrey. In this case, as stated above, Godfrey, the plaintiff was not a member of the band, but arranged music for many of their songs. ${ }^{138}$ Godfrey had allowed over 14 years to pass before he made a claim to copyright infringement. ${ }^{139}$ The court held Godfrey to have impliedly licensed his work to Lees and other band members. The issue, among others, was whether Godfrey was estopped from revoking his implied licence, and asserting his copyright, after 14 years. ${ }^{140}$ If the conduct required was an action, then Godfrey providing access to the music he had arranged itself would be sufficient, together with the detrimental reliance of Lees and others, for proprietary estoppel to be established. It cannot be that providing such access in itself represented to Lees and others that Godfrey was not

\footnotetext{
${ }^{138}$ Godfrey (n 15) 310-1.

139 ibid 312.

140 ibid 322.
} 
going to assert his copyright entitlement in future. Otherwise, the positive act, such as taking part in a recording in Beckingham and Fisher, alone would lead to an irrevocable implied bare licence, which is an unjust outcome for copyright owners. Therefore, it is not the copyright owner's action that must be considered in case of implied bare licences. This eliminates the Taylors approach above.

Once the implied licence comes into existence, it continues by the continuation of the neutral act, until, as explained section 2.1 above, the neutral act becomes a negative act. If the neutral act is absolute, then the copyright owner does not engage in any action at all up to the point of revocation. Inaction and reliance are closely related in that the longer the inaction, the greater the likelihood of reliance. On this view, it is Godfrey's standing by for 14 years which made Lees and others rely on the continuation of the implied licence. Thus, if the required conduct on part of the copyright owner is inaction, then the Thorner or the Willmott approach above could apply.

This brings us to the next question on the need for the assessment of knowledge. The Thorner approach disregards knowledge, whereas the Willmott approach requires an assessment of knowledge. For an inaction on part of the copyright owner alone to make her lose a part of her ownership powers, ${ }^{141}$ one must enquire what caused the inaction. And the cause of such inaction may well be the that the copyright owner was unaware of her rights. For implying a licence, section 1.3 above explained that the positive act and the neutral act are meaningful only if the copyright owner has the requisite knowledge. It cannot be that such knowledge can be disregarded for a more drastic eventuality, namely being estopped from revoking such implied licence. Therefore, the Thorner approach cannot apply.

\footnotetext{
141 A person cannot acquire copyright by adverse possession. Fisher v Brooker [2009] UKHL 41 [78].
} 
The Willmott approach is, therefore, the most suitable approach for implied bare licences. This approach requires an assessment of the knowledge of the copyright owner as to the mistake on part of the licensees as to their rights, and copyright owner's own rights. This differs from the knowledge requirement for implying a bare licence in that, in implying a bare licence, the courts only consider copyright owner's knowledge of her own copyright entitlement. In Willmott, requiring additionally the knowledge of the mistaken belief of the licensees consolidates and increases the threshold of the copyright owner's knowledge. Therefore, the low threshold of copyright owner's knowledge as to his own rights normally found sufficient in implying a licence, will not be sufficient to establish proprietary estoppel. The consequences of proprietary estoppel are more drastic in making a copyright owner lose a part of her powers of copyright ownership irrevocably. Further, the timing when copyright owner is required to have such knowledge is when the licensees begin to act on the faith of the continuation of the implied licence. ${ }^{142}$

Applying the Willmott approach to Godfrey, one must assess Godfrey's state of mind as to whether he knew that Lees and others were under a mistaken belief as to their entitlement, and his own copyright entitlement inconsistent with theirs. As discussed above, Godfrey had a vague sense of his rights, reflected in his insistence on the existence of a profit sharing agreement, and that his contribution be recognised in the albums. ${ }^{143}$ When Godfrey became aware of his rights as a copyright owner, he tried to convince Lees and others of his rights. They insisted on believing that only the composer of the song becomes a copyright owner, and not the arranger. This led Godfrey not to assert his copyright claim. ${ }^{144}$ The only option

\footnotetext{
${ }^{142}$ Kammins (n 124).

143 Godfrey (n 15) 330-31.

144 ibid.
} 
open to Godfrey to convince Lees and others that they were mistaken was to take legal action. Thus, although Godfrey had not fully articulated his knowledge of his own copyright entitlement and the rights of Lees and others contrary to his own, he was still held to be estopped from revoking his licence.

In Fisher, Fisher had raised the issue of having rights in the song and was met with a rebuff. ${ }^{145}$ Even with the lapse of 38 years, it was still held that Brooker and others could not have laboured under the belief that Fisher would never raise a claim to copyright in the song. ${ }^{146}$ Likewise in Beckingham, Valentino had maintained from the start that he knew he could assert his rights to the music, but that he had refrained from doing so. Although Valentino only made a claim to his copyright about nine years later, the court held that Hodgens still could not have assumed that Valentino will never make such a claim. ${ }^{147}$ In both these cases, Fisher and Valentino not only knew of their own copyright entitlement, but also that the respective licensees were mistaken in claiming their rights. Despite this, Fisher's and Valentino were not estopped from revoking their licences.

In none of these cases, however, was a reference to Willmott made. Indeed, the court did not explain with any level of precision what is required of the copyright owner to trigger detrimental reliance by the licensees. Evidently, in these cases, the court did not appreciate the nuance of the copyright owner's knowledge, which led to unfair results.

\section{Detriment due to reliance}

Detrimental reliance is common to all strands of proprietary estoppel, and the test is less

\footnotetext{
145 [2006] EWHC 3239 (Ch) [57].

146 ibid [70].

147 Beckingham (n 18) [65].
} 
controversial. However, in Godfrey the court erred in its assessment of the detrimental reliance. The songs at issue were not an immediate success. After Godfrey left the band, it took the remaining members of the band many years to make the songs popular by giving many live performances, which Lees and others claimed to be a loss making and expensive affair. ${ }^{148}$ Through the years of their hard work to earn popularity and recognition, Godfrey was completely absent. Therefore, the detriment which the judge was trying to find in Godfrey was the financial outlay and the physical efforts Lees and others had put in under the belief that they were the only ones entitled to the copyright in the songs.

This assessment of detriment is problematic. In this regard, Taylors rightly held that detriment should be such that it owes its result directly to the reliance placed. ${ }^{149}$ The connection between detriment and reliance should be such that the detriment should not have occurred without the reliance being placed by the licensees on copyright owner's conduct. In Godfrey, the remaining members of the band would have incurred the expenditure and invested efforts to promote the song regardless of whether they believed Godfrey could make a claim for his copyright. In other words, it is not their reliance on Godfrey not making a claim for his share in copyright that prompted them to incur expenditure to promote the songs. They would have incurred these expenses in any event, as that is what bands do - promote their songs. The court erred in concluding that Lees and other members of the band suffered detriment in reliance of Godfrey not making a copyright claim.

In Fisher, on the other hand, Fisher's contribution was significant, and the band members were aware of that. The song was an instant success. Its fame only grew over the

\footnotetext{
148 Godfrey (n 15) 334-45.

149 Taylors (n 125) 153.
} 
years. ${ }^{150}$ The first eight bars of music of which Fisher was the author, had been so successful that it was being independently exploited, such as for ringtones of mobile phones. ${ }^{151}$ The court was willing to accept that the defendants could not have harboured the belief that Fisher would never stake a claim, ${ }^{152}$ unlike in Godfrey. This appears to be also the reason why the judges in Fisher believed that there was no detriment caused; but on the contrary the band members were financially very handsomely rewarded, including with what would otherwise have been Fisher's share. The court held that it was clear from the evidence that it was not solely because of the efforts put in by the other members of the band in promoting the song, that it became successful. ${ }^{153}$ Thus, in Fisher the other band members rode on the initial success of the song due largely to Fisher's contribution. ${ }^{154}$ As such, in Fisher it was held that the defendants were unable to establish detriment, and therefore their claim to estoppel failed.

In Beckingham, Godfrey was distinguished based on the fact that the success of the song was not due to the efforts of the remaining members of the band labouring under the belief that Valentino would not make a claim. The success of the song was quite fortuitous in being featured in the automobile company, Volkswagen's advertisement in $1993 .{ }^{155}$ Indeed, the band had broken up long before this, and it could not be said that there was any detriment caused to the defendants by Valentino's non-assertion of his rights all those years. There was also no reason for the defendants to believe that no claim would be made, since Valentino had informed the band that he knew of his rights and was not going to assert it. The court found

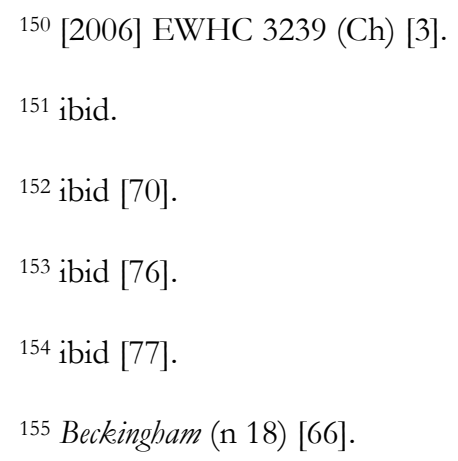


that after the song's success in 1993, it was fully open for Valentino to change his mind, and assert his ownership. As such, it was held that Valentino had successfully revoked his licence.

The commercial success of the song should not have been the criterion for the courts to consider whether there was a detrimental reliance, in both Fisher and Beckingham. It should have been the same reasoning here as argued in relation to Godfrey, that the band members would have gone ahead to expend effort and money to promote the songs anyway. Instead, the court went on to discuss how the song had become successful, and the band did not need to expend much effort or money to promote it. This has the potential of setting a precedent that in a joint authorship scenario, only if a joint author's contribution is spectacular, a court will hold that the remaining members of the band did not suffer detriment. If they needed to spend money and effort to promote the song, then the court is likely to hold that there is a detrimental reliance, despite the fact that they would have expended these anyway, and not in reliance of a co-author's lack of assertion of copyright ownership.

\section{Over-emphasis on unconscionability}

It appears that in their assessment of proprietary estoppel, sometimes the courts are coloured by a pre-conceived notion on unconscionability. In Godfrey, the court's assessment was based entirely on unconscionability caused to Lees and others due to their detrimental reliance. In Godfrey, the court strongly supported the approach in Taylors. ${ }^{156}$ Since Godfrey's engagement with the songs was largely as an arranger of the music, the defendants had assumed that Godfrey had no copyright. ${ }^{157}$ The judge held that the fact that the defendants were incorrect in their belief that Godfrey did not have copyright is not relevant here. The fact that Godfrey

\footnotetext{
156 Godfrey (n 15) 333.

157 ibid 333-34.
} 
allowed them to believe it and did not do anything to change it is the relevant fact. This influenced the court to conclude that his behaviour was unconscionable. ${ }^{158}$

However, Godfrey had taken a pragmatic view that there was no point in going to the court until the songs were successful. Godfrey avoiding expensive copyright litigation could not have itself been unconscionable. In any event, as a person who arranged music for these songs, Godfrey could not have done more than writing those arrangements. He was not part of the band, and therefore, his efforts in making the song a success would necessarily be different. When the songs did become a success, it would have been to some extent also because of Godfrey's arrangement of music, which the other members of the band had used, without having to pay anything to Godfrey. Given that the judge addressed none of these issues beneficial to Godfrey to this level of detail, the decision may have been influenced by the judge's subjective bias in assessing unconscionability, as he regarded Godfrey's contribution not impressive, being confined only to the background. This is exactly the danger of subjectivity in assessing unconscionability that commentators have warned of.

\subsubsection{Remedy to enforce proprietary estoppel}

In the implied licence context, a successful claim of proprietary estoppel will lead to the implied licence being held irrevocable. An example of this is Godfrey. Godfrey had asked for a declaration as a joint author of the works in issue, in addition to a share of profits. Although the judge held Godfrey to have been entitled to joint ownership in those works, he simply dismissed the suit by ruling that Godfrey was estopped from asserting his claims against the defendants. Technically, it is still possible that if someone other than the defendants in this

158 ibid 334. 
case sought to licence the songs Godfrey had arranged (for example, for a cover version), then Godfrey's consent will still be necessary, which he can charge a fee for.

If the claim for proprietary estoppel fails, then the implied licence becomes revocable, but only prospectively. This means that an act already performed while the implied licence was in existence is protected (a licence acted upon). ${ }^{159}$ Some commentators call implied licences estoppel licences. However, this terminology adds nothing to the conception of implied licence. On the contrary, it confuses the boundaries between an implied licence, its continuation, its revocation and its irrevocability due to proprietary estoppel, as explained in this Chapter.

This was seen in Brighton, where it was held that Brighton could revoke her implied licence, ${ }^{160}$ but only prospectively. Jones had entered into commitments like licensing Jones' script to other production houses. The court held that it would now be unconscionable to compel Jones to reopen all these licences, and to account for all the profits allegedly due to Brighton. ${ }^{161}$ However, it is not because of unconscionability that these licences could not be reopened, but rather because they were entered into when the implied licence was in force. A declaration of ownership which Brighton had sought was granted, allowing Brighton to revoke her implied licence prospectively, with Jones having to re-negotiate with Brighton if Jones wished to exploit the play in the future. ${ }^{162}$

\footnotetext{
${ }^{159}$ Harpum, Bridge and Dixon (n 113) para 34-012; see also Armstrong v Sheppard \& Short Ltd [1959] 2 QB 384, 399.

160 Brighton (n 12) [77].

161 ibid [79].

162 ibid [60], [96].
} 
This was the case also with Fisher and Beckingham in that they were not allowed to reopen the licences already entered into, or seek compensation for the exploitation of the work when their implied licence was still in force.

Since in many cases a licence is implied based on a low threshold of copyright owner's knowledge of her entitlement as argued in section 1.3.1 above, it is reasonable not to rely on this knowledge to deprive her of a part of her copyright interest. It stands to reason therefore, that in very rare cases, proprietary estoppel may succeed making a licence irrevocable. I do acknowledge that the ability of copyright owners to revoke their implied licence affects the other members of the band and record companies. However, if such revocation is only prospective, the future exploitation of the work can be more inclusive. This gives an opportunity to struggling copyright owners to end a gratuitous implied licence, and negotiate a contractual licence.

\section{Conclusions and Connections}

This Chapter began rationalising the case law on consent-based implied bare licences with the framework proposed in Chapter II. In the process, it demonstrated that even if in some cases the positive act and the neutral act are uncontroversial, it helps to appreciate that they exist, and to identify the facts that represent these acts. The discussion on the knowledge of the circumstances identifies important nuances that are essential to connect the conduct of consenting to the state of mind. Most important of them was the knowledge of the copyright owner of her own entitlement to copyright. Although an insistence on the actual knowledge is theoretically sound, we saw that pragmatic circumstances might encourage courts to hold as sufficient only a sense of proprietary attachment, rather than an articulation in terms of copyright ownership. 
The discussion on proprietary estoppel further underscores the need for having an analytical understanding of implied bare licences. In this vein, not only is the identification of the positive and the neutral act essential to ascertain the relevant strand of estoppel that must apply, but also the assessment of the knowledge of the copyright owner a key element to arrive at a fair result in estoppel cases concerning bare licences.

We now move to Chapter IV to discuss consent-based implied contractual licences. Being consent based, like in bare licences, contractual licences also have an identifiable positive and a neutral act. However, the components of the knowledge of the copyright owner vary from knowing that the licence is gratuitous to knowing that the licence is in exchange for consideration. Further, the assessment of the knowledge changes from the circumstances within the actual knowledge of the copyright owner to the circumstances which ought reasonably to be within the copyright owner's knowledge. A contractual licence also lends itself to a separate analysis of the contractual and the licence aspects, as discussed below. 


\section{Consent-based Implied Contractual Licences}

A copyright owner may consent to her work being used gratuitously or in exchange for value. Chapter III above dealt with implied gratuitous (bare) licences. This Chapter will deal with implied contractual licences. We saw that the only jural relation in a bare licence is that of privilege and no-right. A contractual licence on the other hand, has rights and duties in addition to privilege and no-right. ${ }^{1}$ One of the duties of the copyright owner is not to revoke the licence at will, and the licensee has a corresponding right against revocation. Any termination of the contract is in accordance with its terms. Further, the sanctity of a contract demands that the parties keep to their bargain, and do not renege on their contractual obligations. ${ }^{2}$ The modern significance of implied contractual licences lies in their application to copyright content placed online by or with the consent of the copyright owner, and is subject to terms of use that amount to a contract. ${ }^{3}$

Courts have developed tests to determine whether to imply a term into a contract. If contractual licences were to be regarded only as contracts, then these tests would apply. These tests are broad and general, aimed at ascertaining the joint unexpressed intention of the parties in any type of contract. Whether these tests achieve this objective is open to debate. Even if these tests assist in implying a term, such term is generally any term in a contract. But, a contractual copyright licence is a particular type of contract with a particular type of term being implied, namely a copyright licence. Therefore, these broad and general tests may not provide much guidance for implying a copyright licence within a contract. One requires an appreciation

\footnotetext{
${ }^{1}$ A group of operative facts that create a privilege is a licence, in Hohfeldian terms. Wesley Newcomb Hohfeld, 'Some Fundamental Legal Conceptions as Applied in Judicial Reasoning' [1913-14] 23 Yale LJ 16, 44. See also Chapter II, sections 1.3.2.3 and 1.3.2.4 above.

2 Jack Beatson, Andrew Burrows and John Cartwright, Anson's Law of Contract (30th edn, OUP 2016) 8.

${ }^{3}$ See Chapter VIII below.
} 
of copyright law, and an approach to implication of copyright licences. Let me explain this with an example.

Q engages P, an artist, to create a portrait of Q's family, for a fee. In the language of contract law, Q offers to undertake to pay the fee to $\mathrm{P}$ if $\mathrm{P}$ creates the portrait, and $\mathrm{P}$ accepts it by undertaking to create the portrait for Q. ${ }^{4}$ Given the personal nature of the portrait, they expressly agree that $\mathrm{P}$ assigns his copyright in the portrait to Q. The undertaking to create the portrait and to assign the copyright are the consideration that flows from $\mathrm{P}$ to $\mathrm{Q}$, in return for Q's undertaking to pay. ${ }^{5}$ Assuming all other requirements of a contract are met, ${ }^{6}$ with these mutual undertakings, a contract comes into existence. $\mathrm{P}$ then creates the portrait and hands it to $\mathrm{Q}$, in return for the fee. This part represents the performance of the contract, whereby $\mathrm{P}$ actually assigns the copyright in the work and Q actually makes the payment.

However, if the agreement between P and Q was silent on copyright, in case of a dispute, a court must ascertain firstly, what $\mathrm{P}$ undertook to do with the copyright in the portrait. Such an undertaking would likely have been a term of the contract that the parties would have intended to incorporate. Since the undertaking is not in express terms, the court will try to ascertain if such a term can be implied on the basis that it was jointly intended, but not expressed. Applying the contractual tests of implication of terms here would be too broad and general, because the contract is more specific - one that enables the use of a copyright work by others. Therefore, one must look to the CPDA for the types of interests in copyright

\footnotetext{
${ }^{4}$ Patrick S Atiyah and Stephen Smith, Atiyah's Introduction to the Law of Contract (6 $6^{\text {th }}$ edn, Clarendon Press 2005) 36, 50. Atiyah and Smith define an offer as a proposal by the offeror to undertake to do something or abstain from doing, provided that the offeree will also undertake to do or abstain from doing something. Offeree accepting the offer, creates mutual undertakings. See also, Beatson, Burrows and Cartwright (n 2) 1, 2, 35, where the authors describe a contract in terms of mutual promises, rather than undertakings.

${ }^{5}$ In executory contracts of this nature, consideration lies in the mutual undertakings given in exchange for each other. Atiyah and Smith (n 4) 107.

${ }^{6}$ These include the capacity to enter into the contract, intention to create legal relations and any formality stipulated by law. ibid 93 .
} 
that can be created to enable such use. ${ }^{7}$ These are an assignment (complete or partial) ${ }^{8}$ and a licence (exclusive or non-exclusive). ${ }^{9}$ Therefore, the term implied can only be an assignment or a licence. The implication of this term determines whether the contract eventually becomes an assignment or a contractual licence, and so, I call this the contract stage.

If the court decides that $\mathrm{P}$ undertook to grant a non-exclusive licence to $\mathrm{Q}$, the next stage is to proceed to imply such licence, which identifies what Q can do with the portrait, such as whether Q can sell the portrait to a gallery or print postcards of the image and so on. I call this the licence stage, as the extent of licence is determined at this stage.

Identifying the contract stage and the licence stage matters because, assignments and exclusive licences are implied less frequently compared to non-exclusive licences. This makes the analysis at the licence stage more important. Chapter II proposes a framework for implying a consent-based copyright licence, which I argue, is more appropriate at the licence stage. Applying tests of implication of a term into a contract for implying contractual copyright licences not only conflates the analysis, but also robs it of clarity.

The copyright owner may create a work upon request from another person, giving rise to a commissioning contract. ${ }^{10}$ Or she may create a work in her own time, and send it to another person to exploit the copyright in her work. An example of this is when a musician creates and records a song, and sends it to a publisher in the hope of being published. ${ }^{11}$ I call this a copyright exploitation contract. A third category is where a consumer purchases in a

\footnotetext{
${ }^{7}$ We can exclude security interest here because the chargee of copyright does not necessarily get to exercise the rights in the work.

${ }^{8}$ CDPA, s 90(1) and (2).

${ }^{9}$ CDPA, ss $90(4)$ and 92.

${ }^{10}$ Blair v Osborne [1971] 2 QB 78.

11 Confetti Records v Warner Music UK Ltd [2003] EWCH 1274 (Ch).
} 
mass-market a chattel incorporating a copyright work. For example, a consumer buying a book of knitted designs. ${ }^{12}$ I call this a consumer contract. In each of these cases, the issue of implied contractual licence may arise. The purpose of this classification is to show how the specific circumstances of these contracts result in different extent to which the copyright work can be used. A commissioning contract, being individually negotiated, provides a wider room, ranging from an outright assignment to a non-exclusive licence being implied. In copyright exploitation contracts, an implied assignment is very rare, though implication may be of an exclusive or a non-exclusive licence. Finally, consumer contracts are in standard form, with no direct contractual relationship between the copyright owner and the consumer. Therefore, there is little or no room for implying any licence at all.

Since the courts apply the tests of implication of contractual terms to contractual licences, it is essential to understand these tests. Section 1 deals with these tests and provides a critical evaluation as to whether the courts provide sufficiently clear guidelines to ascertain the joint unexpressed intention of the parties.

Section 2 turns to the specific context of implied contractual licences in copyright law. It considers commissioning contracts, copyright exploitation contracts and consumer contracts separately under the contract stage and the licence state. Although no court offers this kind of analysis, I argue that such analysis offers a methodical way of understanding contractual licences. At the contract stage, I propose that principles specific to copyright law, ${ }^{13}$ as opposed to tests of implication, should be applied, as necessary. At the licence stage, I propose that the case law be rationalised with the framework proposed in Chapter II for implying a consent-based copyright licence, which consists of the positive act, the neutral act

\footnotetext{
12 Roberts v Candiware Limited [1980] FSR 352.

${ }^{13}$ Robin Ray v Classic FM [1998] EWHC Patents 333.
} 
and the knowledge of the copyright owner, ${ }^{14}$ modified to fit the contractual frame. By rationalising in this manner, I propose to achieve the same objective as in Chapter III, namely to make the courts' reasoning more transparent, point out the problems where they exist, and suggest how the reasoning could be improved.

Section 3 provides conclusions, and connections to the upcoming chapters.

\section{Principles of Implying a Term into a Contract}

When a contract is in express terms, the process of interpreting a contract involves assigning to the language of the text the most appropriate meaning which the words can legitimately bear. ${ }^{15}$ However, the express terms do not, and perhaps cannot possibly provide for all eventualities. Gaps in contracts appear due to reasons as mundane as oversight, poor drafting, or increased transaction costs if every term is expressly incorporated. ${ }^{16}$ Indeed, the parties might fear that if some terms are insisted upon, an agreement might not be reached at all, or may result in other terms (normally price) being altered. ${ }^{17}$

Whatever the reason, if the gaps do not render the contract unenforceable for uncertainty, ${ }^{18}$ a contract could exist with incomplete terms. In the absence of express terms, the courts must engage in the process of implication, which permits the court to plug what it perceives to be gaps in the express terms. ${ }^{19}$ In these situations, given the benefit of the

\footnotetext{
${ }^{14}$ See Chapter II, section 3.1.1 above.

${ }^{15}$ Equitable Life Assurance Society v Hyman [2002] 1 AC 408, 459.

16 Atiyah and Smith (n 4) 155.

${ }^{17}$ Hugh Collins, The Law of Contract (4th edn, Lexis Nexis 2003) 240.

18 Beatson, Burrows and Carwright (n 2) 64-73.

${ }^{19}$ Gerard McMeel, The Construction of Contracts - Interpretation, Implication and Rectification (2 ${ }^{\text {nd }}$ edn, OUP 2011) para [10.04].
} 
hindsight, the courts may be tempted to make or improve the contracts for the parties. Neither is desirable. ${ }^{20}$ Therefore, the courts try to ascertain the terms that the parties intended to include, although did not do so expressly. ${ }^{21}$ The courts claim to maintain 'the classical view that it is the parties, and not the courts, who determine the content of contract. ${ }^{22}$

\subsection{Tests to Imply a Term in Fact}

Given that the ultimate rationale of contract law is to give effect to the intentions of the parties to transact or cooperate with each other, ${ }^{23}$ the courts have formulated tests to assess the unexpressed joint intention of the parties. The joint intention of the parties is to be assessed objectively, given the difficulty in ascertaining the true and subjective intention of the parties. The tests approach the issue from three different, but overlapping, perspectives - the commercial purpose that the parties tried to achieve (business efficacy), a reasonable man (officious bystander) and viewing the contract as a whole against its commercial setting (holistic). In applying these tests, the courts try to ensure that the term being implied is formulated with 'sufficient degree of precision, without over-complication or artificiality. ${ }^{24}$

\subsubsection{Business Efficacy Test}

Business efficacy can be described as the commercial purpose of a transaction. When the intention of the parties is not readily discernible, the strategy is to look at the commercial objective that the parties intended to achieve. The underlying presumption is that in entering

\footnotetext{
20 Philips Electronique Grand Public SA v BSB Ltd [1995] EMLR 472, 480-82.

${ }^{21}$ Collins (n 17) 222.

${ }^{22}$ Atiyah and Smith (n 4) p 156.

${ }^{23} \mathrm{McMeel}$ (n 19) para [1.65].

${ }^{24}$ Philips (n 20) 482-83.
} 
into a contract, the parties intend to achieve this objective, and not to frustrate it. ${ }^{25}$ This test was pioneered in The Moorcock case, where the owner of a steamship contracted with the owner of a jetty to moor his ship. The ship was damaged due to the low tide. The safety of the jetty to moor the ship was regarded the commercial purpose for which the contract was entered into. Accordingly, Bowen LJ held: ${ }^{26}$

In business transactions such as this, what the law desires to effect by the implication is to give such business efficacy to the transaction as must have been intended to all events by both parties who are business men...

The term must only embody what is necessary to achieve business efficacy, as opposed to what is reasonable. ${ }^{27}$ Judges refer to this test extensively. However, the problem with this test is that the parties to a contract may not always have a unified business objective. If the term is implied, one party's objective may be achieved and if a term is not implied, the other party's objective may be achieved. Therefore, it is doubted if this test will always yield a just result. ${ }^{28}$ Together with the officious bystander test below, a court may only imply a term which both parties as reasonable persons would have agreed to, despite their conflicting commercial motives. ${ }^{29}$

\subsubsection{Officious Bystander Test}

In Shirlaw $v$ Southern Foundries (1926) Ltd, a question arose as to the interpretation of the articles of association of a company in relation to the appointment and removal of its managing director, and MacKinnon LJ crystallised the test as follows. ${ }^{30}$

\footnotetext{
${ }^{25}$ Collins (n 17) 240.

26 (1889) 14 PD 64 (CA) 68.

${ }^{27}$ Reigate v Union Manufacturing Co (Ramsbottom) Ltd [1918] 1 KB 592, 605.

${ }^{28}$ Collins (n 17) 240.

${ }^{29}$ Luxor (Eastbourne) Ltd v Cooper, [1941] AC 108.

${ }^{30}$ [1939] 2 KB 206, 227. Affirmed by the House of Lords in [1940] AC 701.
} 
Prima facie that which in any contract is left to be implied and need not be expressed is something so obvious that it goes without saying; so that, if, while parties were making their bargain, an officious bystander were to suggest some express provision for it in their agreement, they would testily supress him with a common 'Oh, of course!'.

A parallel in other areas of law would be a reasonable man's test. ${ }^{31}$ This test applies to cases where the term being implied is 'so obvious that it seemed unnecessary to state it formally. ${ }^{32}$ Stated this way, this test seems to bring the court the closest to the joint unexpressed intention of the parties. However, this might be oversimplifying the situation. If the term to be implied was so obvious that its implication went without saying, there would have been no dispute requiring a court to resolve it. The test adopts the standard of an officious bystander to determine what is obvious, and Lord Hoffmann cautions that any attempt to make more of it might endanger the objectivity of the test. ${ }^{33}$

Given its limitations, this test cannot alone be conclusive. Commentators point out that since 'the officious bystander has not in fact intervened,' the courts must resort to other evidence from which to infer the intent of the parties, such as the express terms used and their meaning. ${ }^{34}$

\subsubsection{Holistic Test}

Lord Hoffmann applied this test first in Banque Bruxelles $S A v$ Eagle Star. ${ }^{35}$ In this case, certain lenders sued a valuer for inflating the value of the security over which they lent. Implying a duty of care in valuing the security, Lord Hoffmann observed that the process of implying this

\footnotetext{
${ }^{31}$ See Lord Hoffmann, 'Anthropocentric Justice: The Reasonable Man and his Friends', (1995) 29 Law Teacher 127, 138-140. cf Attorney General v Belize [2009] UKPC 10 [16].

32 Collins (n 17) 222; see also, Atiyah and Smith (n ...) 156.

33 Attorney General v Belize [2009] UKPC 10 [25].

${ }^{34}$ Collins (n 17) 239.

35 [1997] AC 191.
} 
duty is 'one of construction of the agreement as a whole in its commercial setting. ${ }^{36}$ In Attorney General $v$. Belize, ${ }^{37}$ the issue was whether the articles of association of a company impliedly prevented the removal of directors other than by shareholders holding specific shares. Holding that there was such an implied term, Lord Hoffmann crystallised this test. He stated that the court must ascertain whether the implication 'would spell out in express words what the instrument, read against the relevant background, would reasonably be understood to mean. ${ }^{38}$ Implication of the term therefore, is not an addition to the instrument. It only spells out what the instrument means. ${ }^{39}$

To the extent that Lord Hoffmann's formulation focuses the enquiry on the agreement as a whole, it is less controversial. After all, when the courts apply the business efficacy test, they do not lose sight of the agreement, as it is the commercial purpose of the agreement that they are trying to discern. When the courts look at the officious bystander test, it must have had the sight of the agreement to see what appears obvious. In Lord Hoffmann's own admission, his test is not new, and all tests lead to the same objective, namely to ascertain what the agreement means. ${ }^{40} \mathrm{He}$ states that although the other tests are not irrelevant, these tests should not be treated as if they have 'a life of their own. ${ }^{41}$ The Supreme Court in Marks and Spencer plc v BNP Paribas, reaffirmed the traditional tests of business efficacy and officious bystander, and urged not to regard the holistic test as changing the law. ${ }^{42}$

\footnotetext{
36 ibid 212.

${ }^{37}$ Belize (n 33).

38 ibid [21].

39 ibid [17]-[18].

40 ibid [27].

41 ibid [22].

42 [2015] UKSC 72 [24].
} 


\subsection{A critique of the tests}

Each of these tests has its own inadequacies, and none can be applied in isolation. Additionally, the way these tests are applied by the courts offers little help in understanding the methodology. It is not always clear whether these tests demand only that which is the minimum necessary to be implied to achieve business efficacy, or something higher, because in practice, the courts do not stay true to the minimalist approach. Even when the courts justify their conclusions based on obviousness, in practice, 'what goes without saying depends on a broad network of assumptions and beliefs, including ordinary notions of what is reasonable. ${ }^{43}$ In most cases, the courts only pay a lip service to these tests, and come to a conclusion based on what they find reasonable, fair or efficient. Some commentators argue that substantively, what is reasonable is typically the same as what is necessary for business efficacy or what goes without saying. ${ }^{44}$

Lord Neuberger in Marks and Spencer noted that the test of necessity is not that of absolute necessity for business efficacy, but that without the term the contract would lack 'practical or commercial coherence. ${ }^{45} \mathrm{He}$ also noted that necessity is a value judgment, and that if a term satisfies the other requirements, 'it is hard to think that it would not be reasonable and equitable. ${ }^{36}$ Although these words clarify that the approach to business efficacy is not minimalist, it is not clear what it is replaced with - reasonable necessity? In general, there is nothing wrong in a court seeking to achieve a reasonable, fair or efficient conclusion to a

\footnotetext{
43 Atiyah and Smith (n 4) 159.

44 ibid 158.

45 Marks and Spencer ( $\mathrm{n}$ 42) [21]. Interestingly, the Supreme Court doubted whether implication is part of interpretation, as implication requires more factors to be considered than interpretation. ibid [27]. Some commentators disagree. See Beatson, Burrows and Cartwright (n 2) 165.
}

46 Marks and Spencer (n 42) [21]. 
dispute. Indeed, the discussion below will show a preference for conclusions that are reasonable, rather than those that only achieve the minimum necessary. However, the problem lies in the inability of the courts' reasoning to connect between the objectives that the tests seek to achieve and the conclusion arrived at. As such, the value of these tests in developing a methodical way of implying a term in a contract is questionable.

\section{Implied Contractual Licence within the Copyright Context}

The tests above apply to any term in a contract. The following paragraphs contextualise the discussion to copyright law. Given that these tests offer little help in implying a term into a contract in general, they may offer even lesser help in relation to the specific types of contracts and of specific terms of concern here, namely contractual copyright licences. Instead, applying the analytical method of contract stage and licence stage, as I propose, can provide a better guidance for implication.

In this section, I will demonstrate that at the contract stage, applying principles specific to copyright law which the courts have developed in the context of commissioning contracts, should be applied in preference for the general tests of implication (to which the courts insist on paying lip service). At the licence stage, although the courts refer to business efficacy and officious bystander tests, these do not support the courts' conclusions. Therefore, I will demonstrate that rationalising the case law in the light of the framework proposed in Chapter II, can make the reasoning of the court more transparent, and can help address any problems with the courts' reasoning. In this regard, the approach of the holistic test, namely the need to look at both the agreement and the surrounding circumstances, may still be relevant.

This section focuses on three representative types of contracts, namely, commissioning contracts, copyright exploitation contracts and consumer contracts, to demonstrate the 
application of the proposed methodology and framework. The following paragraphs deal with each type of contract.

\subsection{Commissioning Contracts}

The author of a work is the first owner of copyright in the work. ${ }^{47}$ It follows that when the author is contractually engaged to create a copyright work, the author should continue to remain the first owner of the copyright. In some countries, the copyright legislation itself provides for the ownership of the commissioned works, which is different from the first ownership rule. ${ }^{48}$ However, barring certain exceptions like Crown and Parliamentary Copyright, ${ }^{49}$ the CDPA leaves it for the parties to decide the ownership of copyright and the uses permitted contractually. ${ }^{50}$ This contract is normally called a commissioning contract. The case law makes no reference to the two-stage analysis, but I will show in my discussion below that doing so illuminates the reasons for the courts' conclusions.

\subsubsection{Contract stage}

When a person engages another person to create a work for a purpose, consent in favour of the person so engaging (the commissioner), to use the work for that purpose must be within the contemplation of the parties at the time of commissioning. The Court of Appeal confirmed this in Blair. ${ }^{51}$ Here, certain owners of land had engaged the claimant, an architect, to draw

\footnotetext{
${ }^{47}$ CDPA, s 11(1); ACA, s 35(2); HKCO, s 13; SCA, s 30(2).

${ }^{48}$ For example, HKCO, s 15 provides that the person who commissions a copyright work will always have an exclusive licence to make all reasonable use of the work contemplated at the time of commissioning, regardless of the provisions of any agreement between him and the copyright owner.

${ }^{49} \mathrm{CDPA}$, ss 163-167.

${ }^{50}$ CDPA's predecessor, namely the Copyright Act, 1956, s 4(3) provided that a person commissioning a photograph, a painting or drawing of a portrait or an engraving will have the copyright in it, unless there is an agreement to the contrary.

51 [1971] 2 QB 78.
} 
plans to build a house, for a fee. The claimant prepared the plans and obtained planning permission. He was accordingly paid for his services. One of the issues was what rights the owners of the land had to the plans. Lord Denning MR held that: ${ }^{52}$

... the architect impliedly promises that, in return for his fee, he will give a licence to the owner to use the plans for the building on that site. The copyright remains in the architect, so that he can stop anyone else copying his plans, or making a house from them; but he cannot stop the owner, who employed him from doing work on that very site in accordance with the plans.

Lord Denning MR relied on the decision of the Supreme Court of New South Wales in Beck $v$ Montana Constructions Pty $L t d,{ }^{53}$ that if not for the commissioning, the copyright work would not exist, and therefore, at the very least the commissioner must be able to use the work she commissioned. ${ }^{54}$ This distinguishes a commissioning contract from other forms of contracts involving copyright.

However, consent in favour of the commissioner to use the work could be embodied in a non-exclusive licence, an exclusive licence or even an assignment of the entire copyright interest. How does one know whether an assignment was intended or a licence? Historically, the courts had held that under certain circumstances, the very act of creating a copyright work in response to a request from a person commissioning could amount to an implied assignment of the author's copyright interest. ${ }^{55}$ Until exclusive licenses were recognised in the UK by the Copyright Act, 1956, many cases had leaned in favour of an assignment, if it was intended that

\footnotetext{
52 ibid 85.

53 1963] FLR 298, 304-05.

54 ibid 305.

${ }^{55}$ For example, in Pasterfield $v$ Denham [1999] FSR 168, 178, a decision of a Country Court, Pasterfield had created a leaflet for a City Council, and years later the Council permitted Denham to create a revised version of the leaflet. The question was whether the Council had the right to do so. The court held that an assignment had to be implied in favour of the Council, following the line of cases thus far.
} 
the person commissioning must be free to make copies and defend against infringement. ${ }^{56}$ The decision in Robin Ray v Classic FM reviewed this historical position, ${ }^{57}$ and provided guidelines as to whether an assignment or a licence must be implied. ${ }^{58}$

The decision in Ray provides useful guidelines in analysing the contract stage of a commissioning contract, and therefore makes the application of the general tests of implication of contractual terms less relevant. However, Ray itself claims that it followed the tests of business efficacy and obviousness in arriving at these guidelines, which in my view, is not necessarily the case. ${ }^{59}$ The paragraphs below critically evaluate the decision in Ray both for its merits and for its approach.

\subsubsection{Principles in Robin Ray v Classic FM}

Ray, the plaintiff in this case, was a writer and broadcaster of classical music, who was engaged by Classic FM, the defendant, a radio station, to create a document setting forth the categorisation of classical music, and to catalogue the music accordingly. ${ }^{60}$ The terms of engagement were reduced to writing in a consultancy agreement. However, the agreement was silent on copyright. ${ }^{61}$ Once the contract was signed, Ray created the catalogue and handed to Classic FM. Classic FM fed the catalogue into a software, and successfully used it to air classical

\footnotetext{
${ }^{56}$ He was referring to Massine v de Basil [1936-45] MCC 233 and Drabble (Harold) Ltd v Hycolite Manufacturing Co, (1928) MCC (1923-28) 322. Partial assignment was not considered in these cases.

57 [1998] EWHC Patents 333 [43], [46].

58 This case is regarded the locus classicus on the law of implied terms in commissioning contracts in Mary Vitoria, et al, Laddie, Prescott and Vitoria The Modern Law of Copyright and Designs, 4th edn, Vol 1 (Lexis Nexis, 2011) 977.

${ }^{59}$ Ray (n 57) [45(4)]

${ }^{60} \mathrm{ibid}[10]$.

61 ibid [5], [6].
} 
music in the UK. Soon Classic FM also started to exploit the catalogue outside the UK, despite Ray's objections. ${ }^{62}$

Ray's claim of copyright infringement was on the basis that any implied licence granted under the consultancy agreement only allowed Classic FM to exploit the catalogue within the UK, and any extension abroad had to be specifically permitted. Classic FM in turn claimed that even if Ray was the first author of the catalogue, there was an implied assignment ${ }^{63}$ of copyright under the consultancy agreement. ${ }^{64}$ The issue was whether there was an implied licence as Ray contended or an implied assignment as Classic FM claimed. Lightman, J went through the authorities on business efficacy and officious bystander tests, and emphasised that the term implied must achieve the minimum necessary under the circumstances. ${ }^{65}$ Accordingly, he identified the following principles that would apply to determine whether an assignment or a licence might be implied: ${ }^{66}$

(i) A minimalist approach is to be followed; if it is necessary to imply a grant, and the necessity can be fulfilled by either a licence or an assignment, then only a licence should be implied. ${ }^{67}$

62 ibid [13].

${ }^{63}$ An assignment requires to be in writing and signed by the assignor (CDPA, s 90(3)). Therefore, it is technically incorrect to say that an assignment is implied, to the extent that an implied assignment by definition, will not be expressed in writing. If an assignment was intended, courts normally hold that the legal title to copyright remains with the author as the first owner, but the equitable title vests with the commissioner. The equitable owner can compel the legal owner to assign the legal ownership in order to perfect the title of the equitable owner. See A\&M Records Limited v Video Collection International Limited [1995] EMLR 25, 33.

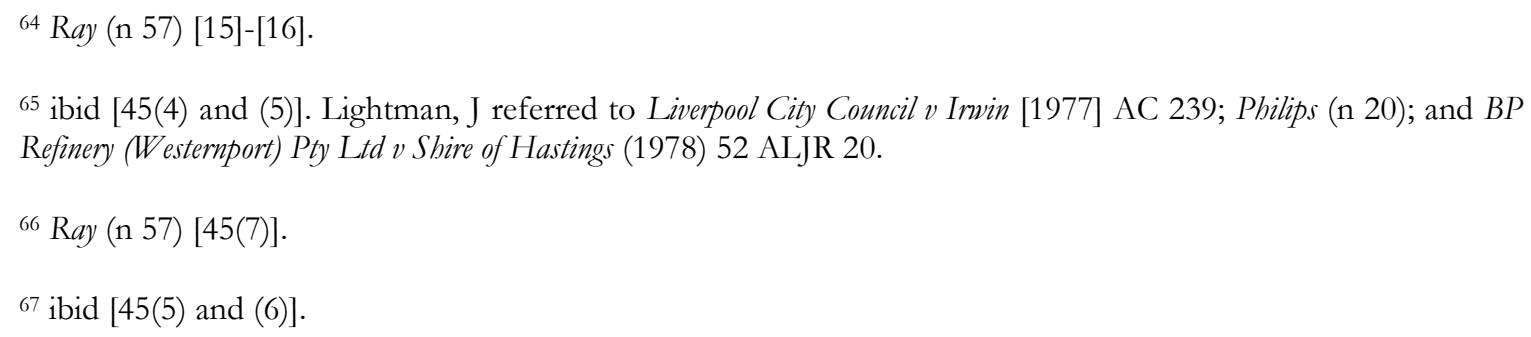


(ii) Some of the situations where an assignment may be implied are where the person commissioning the engagement needs to exclude the contractor from using the work in competition to the person commissioning. ${ }^{68}$ In this regard, Lightman, J identified the following examples where assignments may be required: ${ }^{69}$

a. Where the commissioner intends to sell multiple copies of products incorporating the work commissioned in a market that is free of competition for that product from both the author and third parties;

b. Where the author creates a work that is a derivative work of another work, such as manufacturing drawings of a design that belong to the contractor; and

c. Where the work created is part of a composite work $^{70}$ together with the employees of the commissioner, where the individual work is either not identifiable or cannot be exploited.

(iii) The cases where only an assignment would be required and an exclusive licence does not suffice would be very rare. ${ }^{71}$

On the facts, Lightman $\mathrm{J}$ found that none of the factors justifying an assignment were present in this case. Accordingly, he applied the minimalist approach and held that the parties only intended the grant of a licence.

Ray can be analysed at two levels: firstly, in identifying the situations that warrant implying an assignment. Lightman J's efforts in providing guidelines with clarity are

\footnotetext{
68 ibid [45(7)].

${ }^{69}$ ibid [45(7)(a), (b) and (c)].

${ }^{70}$ There is no definition of a composite work under the CDPA, as s 10(1) only defines a work of joint authorship, and s 10A, a work of co-authorship. Lightman J may have meant joint authorship.

${ }^{71}$ Ray (n 57) [46].
} 
commendable. However, the cases that warrant implying an assignment, as opposed to a licence are those where the author of the work must be excluded from the ownership of copyright, rather than its use. If indeed the minimalist approach was to be followed, then an exclusive licence should suffice. The commissioner as an exclusive licensee can use the work in exactly the same way as she would if she were an assignee, given that an exclusive licensee under the CDPA has substantially similar rights and remedies as an assignee. ${ }^{72}$ Although the line of distinction between an exclusive licence and an assignment is thin, an implied exclusive licence does not grant the exclusive licensee the power to alienate the copyright interest, while an implied assignment grants the assignee that power. The cases that followed Ray demonstrate this point as discussed below.

Secondly, the application of the tests of implying a term into a contract. If the minimalist approach of business efficacy were to be applied, then only a licence could be implied, and not an assignment, given that implying an assignment is substantially more onerous on the copyright owner than a licence. However, Ray went on to lay down rules detailed above, as to when an assignment might be implied, and tried to justify it based on the same minimalist approach. Ray's rules are rooted more in reasonableness than in the joint unexpressed intention of the parties. While the rules laid down provide useful guidelines, the underlying reasoning is unsatisfactory.

\subsubsection{How Ray bas been applied}

The decision in Ray was extensively relied upon in R Griggs Group Limited v Evans. ${ }^{73}$ In this case, Griggs, the claimant, was the manufacturer of the well-known 'Doc Martens' footwear. They

\footnotetext{
${ }^{72}$ CDPA, ss 101 and 102.

73 [2003] EWHC 2914 (Ch).
} 
had two different trademarks, which they wished to combine and create a single mark. They engaged an advertising agency, of which the first defendant, Evans, was a freelance designer. Once the combined logo was created, Evans assigned it to the second defendant, an Australian shoe company (ostensibly, the claimant's competitor). Both Evans and the Australian company claimed that Evans is the original legal and equitable owner of copyright in the combined logo. ${ }^{74}$ Griggs approached the court for a declaration that Griggs was the equitable owners of the combined logo. ${ }^{75}$ It was common ground that the Australian company took assignment of the combined logo with the actual knowledge of the claim by Griggs. ${ }^{76}$

The High Court found that copyright subsisted in the stylised version of the logo. ${ }^{77}$ Having elaborated the principles laid down in Ray, the court found that Evans could not be free to assign the copyright in the combined logo. The court found that business efficacy demanded that the person commissioning needed more than simply a right to use, and this was a clause so obvious that it went without saying. ${ }^{78}$ The court found further that Ray principle of excluding the author from using the work applies here. ${ }^{79}$ The Court of Appeal confirmed the trial judge's findings in its entirety. ${ }^{80}$ It further stated that if an officious bystander were to ask whether the author would retain the copyright and the commissioner only a user right, the parties would have replied with an emphatic no. ${ }^{81}$

\footnotetext{
74 ibid [11].

75 ibid [14].

76 ibid [12].

77 ibid [18]-[19].

78 ibid [36].

79 ibid [37].

${ }^{80}$ [2005] EWCA Civ 11 [19]-[25].

81 ibid [19].
} 
As to why an assignment was required, the court believed that this was a fit case for excluding the author from the use of the work. If that was so, then an exclusive licence would have also sufficed. Indeed, this is one of the criticisms levelled against this case. ${ }^{82}$ However, this criticism appears misplaced. The court did consider implying a perpetual exclusive licence, but held that even if such licence behaved similar to an assignment, it would cause Griggs (as an exclusive licensee) great inconvenience if it had to join Evans in infringement proceedings. ${ }^{83}$ This is perhaps not a sufficiently convincing reason, since as an exclusive licensee, Griggs could also add Evans as a defendant, if he did not cooperate. ${ }^{84}$ The true reason was that there was a need to exclude the author from all rights in the work, not merely the right to use. It is exactly the kind of transaction that Evans entered into, namely of assigning the work to a competitor, that the person commissioning would like to prevent. Therefore, holding that an assignment is appropriate is reasonable. However, since this case closely relies on Ray, it would have been clearer if Lightman J had spoken of excluding the author from the ownership of her work, rather than use, to avoid this confusion.

The court did not consider certain key factors concerning Evans' position. There was no direct contractual relationship between Evans and Griggs, as the advertising agency with whom Griggs had the contract, had ceased business subsequently, and was not a party to the proceedings ${ }^{85}$ Evans was not aware of the actual use to which the combined logo was going to be put. The advertising agency that he was working for only informed him that it was for use in points of sale. Evans argued that had he known that the logo would be used worldwide

\footnotetext{
${ }^{82}$ Rebecca Baines, 'Copyright in commissioned works: a cause for uncertainty', [2005] EIPR 122-23.

${ }^{83}$ Griggs (n 73) [58].

${ }^{84} \mathrm{CDPA}, \mathrm{s} 102(1)$. If the joinder of the copyright owner is regarded inconvenient in all cases, then no exclusive licence can be implied, preferring an implied assignment instead. This is the reverse of what Ray held. Ray (n 57) [46].

85 ibid [11], [40]-[42].
} 
and more widely than on point of sales, he would have charged more. ${ }^{86}$ The minimum business efficacy under these circumstances would have been that only a licence can be implied to enable Griggs to use the work on points of sale, since Evans was not a party to, nor aware of the full commercial background, and had claimed that the price did not represent an assignment of his copyright. However, in the court's view, there was no evidence that Evans would have charged more had he known the scope of the use of the work, and that the amount paid to Evans was commensurate with the amount of skill and labour involved in creating the work. ${ }^{87}$ Since Evans engaged in an act which, at an objective level unreasonable, namely, to assign his work to a competitor of the client, the court decided that an assignment should be implied, depriving Evans of any rights in the work. Even though the court mentioned the tests of business efficacy and officious bystander, in the end it did what was reasonable.

In Lucasfilms v Ainsworth, ${ }^{88}$ the defendant, Ainsworth, prepared a prototype for a helmet and manufactured a number of such helmets, based on the paintings and a clay mould shown to him, and by adding some of his own features. ${ }^{89}$ The difference in this case was that instead of assigning his copyright in the design of the helmet to a competitor of the film maker, the author set up his own competing business selling these helmets. ${ }^{90}$ The claimants who were the producers of the film sued him, alleging that as part of the commissioning agreement Ainsworth is taken to have assigned his rights in the design of the helmets. ${ }^{91}$

\footnotetext{
86 ibid [45], [46].

87 ibid [48], [51]-[52], and confirmed in [2005] EWCA Civ 11 [10]-[11].

88 [2008] EWHC 1878 (Ch).

89 ibid [35]-[36].

90 ibid [85].

91 ibid [86].
} 
Initially, Ainsworth was unaware of the use to which the helmets would be put. The court also accepted that neither party had anticipated the prospect of exploitation of the design of the helmets upon the success of the film. However, the court stated that even if the licensing prospects could not have been foreseen, the 'appearance and "feel" of the film' was key. As such, the court found that a parallel exploitation of the props could not have been the intention of either party. ${ }^{92}$ The court further held that Ainsworth himself was working to render in three dimension what was given to him in two dimension, and therefore would have in any event been unable to exploit the helmets to the exclusion of others who had copyright in the twodimensional work. Therefore, the court took the view that Ainsworth should have known that the claimant would want full exploitation rights for its film. ${ }^{93}$ The court went on to hold that Ainsworth should have known that he would not retain any copyright in them, and that implying an assignment alone makes sense. ${ }^{94}$

Lucasfilm relied on Ray principles and Griggs example. Clearly the difference here was that Ainsworth had only himself been using the copyright work, rather than assigning it. To prevent him from using the work in any way, the court could have implied an exclusive licence, since an exclusive licence prevents even the copyright owner from using the work. To this extent, Lucasfilm continues to be affected by the confusion caused by Ray not only in principle that an assignment is required to prevent use, but also in its application to this case.

Ainsworth took instructions from a middleman, rather than the claimants themselves, ${ }^{95}$ and therefore, was not aware initially of the use to which the helmets might be

\footnotetext{
92 ibid [189]

93 ibid [185].

94 ibid [189], confirmed in [2009] EWCA Civ 1328 [207]-[208].

${ }^{95}$ Lucasfilm (n 88) [34].
} 
put. Even when he came to know of it and started a direct relationship with the claimants, the potential of commercial exploitation was not known. When Ainsworth realised the potential after the success of the film, he wrote to the film producers that they could exploit the helmet moulds, but nothing came of it. ${ }^{96}$ Even if the commercial background of film industry generally is imputed to Ainsworth, implying an exclusive licence would have achieved the minimum necessary for business efficacy, and not an assignment. This would also be obvious because Ainsworth was not trying to and could not have managed to assign his own copyright in the helmet, without the author of the two-dimensional work also consenting to such assignment. However, in the judge's own words, it did what 'makes sense, ${ }^{97}$ i.e., what was reasonable.

Courts have on rare occasion implied an exclusive licence instead of an assignment, of which Coward $v$ Phaestos Limited ${ }^{p 8}$ is an example. In this case Dr Coward, the claimant, created a specialised software for use in trading in hedge funds, for a partnership of which he was a partner. Over time, the employees of the partnership had also assisted in the development of the software, but it was common ground that Dr Coward's contribution was significant. He fell out with the partnership, and it was subsequently dissolved, with its assets transferred to one of the defendants. ${ }^{99}$ The issue was whether the copyright in the software that Dr Coward created had become partnership property, such that Dr Coward had no rights in it; alternatively, that if Dr Coward continued to be the owner, whether there was an implied licence in favour of the successor in title of the partnership, and the scope of such licence. ${ }^{100}$

\footnotetext{
96 ibid [84].

97 ibid [189].

98 [2013] EWHC 1292 (Ch).

99 ibid [1]-[3].

100 ibid [12]-[13].
} 
The court held that the copyright in the software had become partnership property. ${ }^{101}$ However, the court also considered the alternative argument to hold that given the centrality of the software to the business, and the need to exclude Dr Coward from using the software, the implied licence from Dr Coward should be exclusive. ${ }^{102}$

Coward discussed Ray, but only applied the test of necessity. ${ }^{103} \mathrm{~A}$ bulk of the judgment was devoted to explaining why the software had become partnership property, showing how Dr Coward had co-mingled his efforts and his assets with the partnership seamlessly. Therefore, the partnership as a business organisation, the speciality of the software and Dr Coward's own behaviour in relation to the software may have influenced the court to imply an exclusive licence, more than the test of necessity. Nevertheless, implying an exclusive licence appears to be the appropriate for this case.

To conclude, Ray was right to carve out situations in the copyright context where implying an assignment is more reasonable, fair and efficient. Indeed, in narrowing down the term to be implied to the control over the copyright work that each party might want to exercise, whether by way of an assignment, an exclusive licence or a non-exclusive licence, Ray provides clear guidelines specifically applicable to contracts involving copyright. If the flaws pointed out above are addressed, Ray provides reliable pointers to guide the contract stage of commissioning contracts. Further, it would have brought more clarity if Ray and the cases that followed it had not attributed their conclusions to business efficacy or obviousness, since these tests do not fully support Ray guidelines.

\footnotetext{
101 ibid [232], [242]

102 ibid [248]-[249].

103 ibid [199].
} 


\subsubsection{Licence stage}

At the end of the contract stage, one would know if the contract might become a contractual licence or an assignment. Once the court decides that a non-exclusive licence, rather than an assignment or exclusive licence must be implied, then we move to the licence stage to ascertain the actions to which the licence extends.

Ray tried to apply the same minimalist test at both the contract stage and the licence stage. Lightman J held that if necessity requires only the grant of a licence, the ambit of the licence must be the minimum which is required to secure the relevant party the entitlement which the parties to the contract must have intended. But he also went on to hold that the licence accordingly is to be limited to what is in the joint contemplation of the parties at the date of the contract, and does not extend to enable the relevant party to take advantage of a new unexpected profitable opportunity. ${ }^{104}$

Indeed, most cases discussed below refer to the business efficacy and the obviousness tests, but come to a conclusion that achieves more than the minimum necessary. Providing minimalist approach as the reason, but arriving at a result that is more than minimum required in the situation only creates a gap in the court's reasoning. If instead, the cases are rationalised under the framework proposed in Chapter II, the courts' reasoning could be made more transparent, and any problems with the reasoning can be detected.

\subsubsection{Positive act}

While implying a consent-based bare licence, the difficulty is in ascertaining whether there is a licence at all. Therefore, the positive act is crucial in signalling the existence of a licence. Entering into a commissioning contract is already a consensual act on part of the copyright

\footnotetext{
104 Ray (n 57) [45(8)-(9)]
} 
owner, whereby she undertakes to create and hand over the work to the commissioner. The positive act is subsumed within the performance of this undertaking. Sometimes, the positive act may be in return for the agreed consideration being provided. A copyright owner may expect a full or a part payment before the work can be handed over. Nevertheless, the controversy in a commissioning contract is not whether a licence has come into existence, but rather the extent of such licence (actions authorised). However, it does not mean that the positive act does not exist. There is no consent-based licence without the positive act. All this means is that identifying the positive act is neither difficult, nor controversial in a commissioning contract.

\subsubsection{Neutral act}

The neutral act signals the continuance of the licence. Since a contractual licence cannot be revoked, but only terminated on its terms, ${ }^{105}$ a neutral act turning to a negative act can only be for the breach of a contractual undertaking.

As explained in Chapter II, a neutral act in a contractual licence is conditional on the consideration being provided, such as payment. Once the copyright owner performs the positive act, for the copyright owner to perform her undertaking to not interfere with the licensee's use of the work, licensee must perform her undertaking, which is to pay. If it is a one-off payment like in Blair, it is less controversial. If the contract is for a recurring payment, missing or stopping the payment can make the copyright owner turn the neutral act into a negative act, by terminating the licence, claiming the non-payment to be a repudiatory breach.

The neutral act is also conditional on the licensee acting within the scope of the licence. The terms that define the scope of the contract make the neutral act partial. For example, in

\footnotetext{
105 See Chapter II, section 2.3.2 above.
} 
Blair, Blair informing the land owner that the Royal Institute of British Architects (RIBA) conditions (as they existed in 1970) applied by handing them a booklet containing those conditions, ${ }^{106}$ made Blair's neutral act partial. If the licensee acts beyond these terms, the copyright owner can turn the neutral act to a negative act, by approaching the court for infringement. This is what the copyright owner did in the cases discussed below on commissioning contracts. Not insisting on the terms of the conditional neutral act might result in a finding of estoppel by acquiescence against the copyright owner.

The copyright owner must have the knowledge of the terms that make the neutral act partial. This takes us to the section below as to the assessment of the copyright owner's knowledge.

\subsubsection{Knowledge of the copyright owner}

The actions authorised by a licence turn on the knowledge of the copyright owner. ${ }^{107}$ For bare licences, Chapter III identified further aspects of the knowledge of the copyright owner. ${ }^{108}$ These aspects must be fashioned for the contractual context. Normally there is no issue with the knowledge of the copyright owner as to her copyright entitlement, since in many instances, it is because the copyright owner knows of her copyright entitlement that she demands value in exchange for the copyright licence. ${ }^{109}$

Unlike in bare licences where the copyright owner knows that the licence is gratuitous, in a contractual licence the copyright owner knows that a bargain exists. Further, the copyright

\footnotetext{
106 Blair (n 10) 85.

${ }^{107}$ See Chapter II, section 3.1.1.3 above.

108 See Chapter III, sections 1.3.1, 1.3.2 and 1.3.3 above.

109 See the discussion on Barrett v Universal Island Records Ltd [2006] EWHC 1009 (Ch) in Chapter III, section 1.3.1.2, where the claimants' receipt of payments cast a doubt on whether they were truly unaware of their copyright entitlement.
} 
owner must know the circumstances in which the positive and the neutral acts are being performed, similar to bare licences, but in the light of the bargain. The two components therefore, represent the copyright owner's knowledge as to what is within and outside the agreement. ${ }^{110}$ The discussion below will rationalise the case law under these two components of knowledge to make the reasoning of the case law more transparent. At the same time, it will demonstrate that although the courts refer to business efficacy and obviousness in most cases, these tests do not support the courts' conclusions.

\section{Knowledge of the bargain}

A bargain in this context simply means the exchange. A person entering into a contract is taken to have the knowledge of the terms of the contract. The price that a licensee undertakes to pay is a significant component of the bargain. However, the bargain must be assessed as a whole to ascertain, the actions which the copyright owner should be taken to have permitted under the licence, given a specific price. The following discussion demonstrates this.

In Blair, as stated above, the claimant, an architect, was engaged by certain land owners to draw up the outline plans. The claimant had informed the owners that his engagement would be governed by the RIBA conditions (as they existed in 1970). ${ }^{11}$ The claimant prepared complete plans and submitted to the local authority for planning permission. Once the planning permission was obtained, the claimant sent the drawings and the certificate to the owners, together with his bill of costs for the work done. ${ }^{112}$ The owners paid the bill, but did not engage the plaintiff for further works. Instead, they sold the land to the second defendants.

\footnotetext{
${ }^{110}$ Note that this methodology bears resemblance to the holistic test discussed in section 1.1.3 above, in that it requires an assessment of what the agreement means in the light of the surrounding circumstances.

111 Blair (n 10) 85.

112 ibid 83-84. In particular, clause 3(ii) which the judgment referred to, details the work done and its corresponding scale of fees.
} 
The second defendants in turn engaged the first defendant, another firm of architects, to do the work. The first defendant used the claimant's drawings to obtain building permission, putting in details of their own. The building permission was granted and the buildings were built. Claimant happened to see the completed buildings, and sued the first defendant for using his plans and the second defendant for building according to his plans. ${ }^{113}$ Having lost at the first instance, the claimant appealed to the Court of Appeal.

It was not disputed that the copyright in the plans belonged to the claimant. The concern here was the extent of the implied licence, as to whether the implied licence was assignable to the future purchasers of the land from the owners, and could be sub-licensed. ${ }^{114}$

Since the RIBA conditions embodied the bargain and the parties had expressly agreed to be governed by them, the parties must be taken to have the knowledge of these conditions. Widgery LJ found that the RIBA terms did not contemplate that the engagement would run its full course at all times. Various stages of services of an architect were clearly envisaged under the RIBA conditions, with a corresponding payment for a specific service. He disagreed with the claimant that the plans could only be used by the defendants so long as the plaintiff was in their continued service, or that the plans came into existence only to get planning permission. Widgery LJ stated that if this argument was correct, it would allow architects to hold their clients to ransom, which goes against the spirit of the relationship. He concluded that since the claimant had been paid for his services, a licence can be implied, which extended to 'all purposes for which those plans would normally be used, i.e. all purposes connected with the erection of the building to which the plans relate. ${ }^{115}$

\footnotetext{
113 ibid 84.

114 ibid.

115 ibid 86.
} 
On a similar reasoning, Lord Denning MR also held that the implied licence extends to enable the defendants to use the plans for that very building on that site, and for no other purpose. He went on to hold, without giving further reasons, that if the owners sell the site, the implied licence extends also to avail the purchaser.

The effect of the RIBA schedule of fees, according to Blair, was that depending on the stage up to which a person engages an architect, she would have an implied licence to use it for the activities commensurate with that stage. When the claimant applied for and obtained the planning permission, the claimant receiving the payment at this stage made it possible that if the owners wanted to proceed to use the plans to build, they should have the implied licence necessary to perform all actions to build accordingly, including making copies and issuing them to the builders. Since RIBA conditions did not force a client to engage the same architect throughout, if the owners in Blair had themselves engaged another architect after the planning permission was granted, to build according to the approved plans, the implied licence could be sub-licensed to the new architect and any other person who would need it to build.

The above only explains why the owners of the land who had a direct contractual relationship with the claimant, enjoyed the implied licence. However, does this implied licence extend to the successors in title of the land to which the plans relate? For Lord Denning MR, it followed from the owners having paid the full price for the implied licence, in that even when they sold the land, the purchasers received the benefit of the approved plans. The implied licence that allowed the owners to do everything necessary to build according to the plan also allowed them to sell the land and the benefit of the plan together with it, ${ }^{116}$ by

\footnotetext{
116 ibid 85, as he relied on the decision in Beck (n 53), where the facts were slightly different, as discussed under the following section.
} 
assigning the implied licence. This explanation is far from satisfactory, as the price alone cannot determine the assignability, if there is nothing else in the bargain to support it.

In Blair, no test of contractual implication was mentioned. If one were to apply either the business efficacy or the obviousness test, implying a licence in favour of the land owner in Blair would have complied with the minimalist approach. By holding the implied licence also assignable to the successors in title of the land owner, the decision went further, and achieved what was reasonable.

The price paid to the architect was raised again in Stovin-Bradford $v$ Volpoint Properties Ltd. ${ }^{117}$ Unlike Blair, in this case the claimant agreed to accept a nominal fee for drawing up and applying for the planning permission, which was far less than what he would have been entitled to under the RIBA terms. In his invoice the claimant stated that the copyright in the drawings belonged to him, and that his permission would be required for any reproduction of the drawings. ${ }^{118}$ Before the planning permission was given, the plaintiff resigned from the project. Although planning permission was refused at the first instance, the defendants managed to resubmit and obtain it. However, the claimant was unaware of the resubmission and the eventual grant of the planning permission. ${ }^{119}$ Although the defendants had not used much of the plaintiff's plans, they had used the most distinctive part of plaintiff's design, which made the plaintiff sue for copyright infringement. ${ }^{120}$

Although the RIBA conditions were not expressly applied, both parties were aware of the existence and application of these conditions. The defendants contended that Blair was a

\footnotetext{
117 [1971] 3 All ER 570.

118 ibid 572.

119 ibid 573-74.

120 ibid.
} 
binding authority on the court and that once the claimant was paid for his services, the defendants were free to use the plans for all purposes for which the plan was prepared. The court disagreed. Lord Denning MR stated that when the architect charges the full scale fee for the work done, that fee in the ordinary way must be taken to include permission to use the plans for the building of that very house. He further held that the scale charges for partial services are so fixed that they contain a 'built-in' compensation for the use of the design and drawings right through till the completion of the work. ${ }^{121}$ Since the claimant had only charged a nominal fee in addition to stating on his invoice that any reproduction required permission, it meant that he intended the plans not to be used for building purposes. If the defendants wanted to use the plans, then they would have to pay the plaintiff the full RIBA scale charges to have the implied licence to carry out the building works. ${ }^{122}$ No licence was implied in the defendants' favour.

Stovin-Bradford hinged on the fact that the architect was not paid according to the scale for the work done, but only nominal fee. However, it was clearly a part of the bargain also that copyright ownership would remain with the claimant and a licence would be required for any reproduction. These aspects together influenced the court's decision, ${ }^{123}$ reinforcing that the bargain as a whole must be considered, and not the price alone. Although business efficacy was mentioned, it is the analysis of the bargain that was pivotal in deciding whether to imply a licence.

In Stovin-Bradford, the defendant sought the benefit of the implied licence only for himself, and not any successors in title. Neither the price paid, nor the terms of the bargain

\footnotetext{
121 ibid. 574-75.

${ }^{122}$ On this point, all three judges agreed. ibid 573-81.

123 ibid 575.
} 
would have permitted the use of the plans by a purchaser from the person commissioning the plans, in this case. But what if there is a successor in title, but there is no contractual relationship between the person commissioning the plans and the person using the plans?

This point was raised again in a Scottish Court in Muir Dorrans v The Shand Partnership. ${ }^{124}$ The owner of the land was not the one to instruct the claimant, the architect, to prepare plans; instead it was a developer who was interested in developing the land. However, this developer never proceeded with his plans once the planning permission was obtained. The land was subsequently sold twice over, finally to one of the defendants who started developing the land based on the planning permission obtained. ${ }^{125}$ The RIBA conditions in existence at the time of commissioning provided for the scope of the licence as extending only to 'the client', and that the benefits and obligations under the agreement were not assignable by either party without the consent of the other. ${ }^{126}$ Defendants relied on Blair and Beck to argue that as a matter of principle the licence was assignable.

Lord Kingarth rightly distinguished the facts of this case from Blair and Beck, in that there was no contractual relationship between the person commissioning the plans and the person who set about to build in accordance with the plans. The agreement was between the claimant and the first developer, and the RIBA conditions that applied here expressly provided that copyright in the plans stayed with the architect, and defined the extent of the licence given to the client to exclude the assignability of the licence. Therefore, he held that there was no need to imply a term into this agreement. ${ }^{127}$ The first developer had not tried to assign the

\footnotetext{
$1242003 \operatorname{Scot}(\mathrm{D}) 21 / 12$.

125 ibid [2]-[3].

${ }^{126}$ RIBA Terms, 1992, $\mathrm{Cl} 2.3 .1$ and $\mathrm{Cl} 1.4 .1$, respectively.

127 Muir (n 124) [16].
} 
benefit of the agreement, and thus, neither the facts of the case nor the terms of the agreement justified implying a term that the licence was assignable. ${ }^{128}$

In Muir, the persons who came to take advantage of the plans were not privy to the contract between the person commissioning (the first developer) and the claimant. Again in Muir, the minimum necessary for business efficacy was mentioned. However, the decision hinged more on what the copyright owner knew about the contract he had entered into, and how that did not include the use of the plans by the non-parties to the commissioning contract, rather than on the need to achieve business efficacy.

The issue of the price paid also arose in Ray, where Classic FM had argued that by the

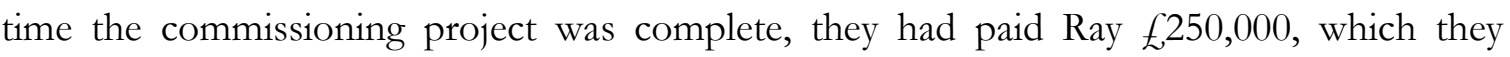
claimed to be substantial enough to imply a licence wider (than being limited to the UK). ${ }^{129}$ Lightman J did mention Blair and Stovin-Bradford, and reiterated that the amount of fee paid could determine the extent of the implied licence. ${ }^{130}$ However, he noted that the parties had not envisaged such a significant payment at the time of entering into the agreement; it became a significant amount over time. Lightman J further relied on the Recital A of the consultancy agreement, which said that Ray's work would be used for enabling Classic FM to carry on its business, namely to broadcast classical music. ${ }^{131}$ He interpreted this to extend only to the UK, thereby confining the implied licence only to the UK.

The recital, however, did not mention that Classic FM carried on business only in the UK. It was clear from a plain reading of the recital that it was only a background statement

$$
\begin{aligned}
& 128 \text { ibid [20]. } \\
& { }^{129} \text { Ray (n 57) [5]. } \\
& 130 \text { ibid [45(8)] } \\
& 131 \text { ibid [48]. }
\end{aligned}
$$


that Classic FM carried on business in classical music. Lightman J may have meant to say that this was how the parties understood it at the time of entering into the contract, given that the amount to be paid was not known upfront. Therefore, Lightman J's assessment was as to what the parties knew about the bargain. His approach of looking at the agreement as a whole, and not simply the price paid, was also appropriate. But acknowledging that that was what he was doing would have provided a better reasoning than a dogmatic insistence on business efficacy. In his eagerness to imply in principle only that which is the minimum required for business efficacy, he failed to provide clear enough reasons on the facts, as to why the scope of the agreement was confined to the UK. ${ }^{132}$

The dispute is not always about the price paid, but could also be about the mutual entitlements of the parties to a commissioning contract. A good example is Wilkinson $v$ London Strategic Health Authority. ${ }^{133}$ Here, Dr Wilkinson, the claimant, was the author of Wilkinson Variant, a methodology of teaching communication skills to nurses while treating cancer patients. The defendant engaged Dr Wilkinson to bring together many such methodologies under one unified programme. As such, a substantial part of the works that Dr Wilkinson had authored before entering into this contract was taken for preparing the course materials for the unified programme under the defendant's auspices. The agreement engaging Dr Wilkinson provided that the intellectual property in any new works created due to this engagement will be owned by the defendant. The agreement with Dr Wilkinson was terminated according to its terms, but the defendant continued to use the material created under the agreement elsewhere, including abroad, and for diseases other than cancer. Dr Wilkinson claimed that the defendant infringed her copyright and that any implied licence did not extend to providing

132 ibid [47]-[48].

133 [2012] EWPCC 48. 
training in other countries and for other diseases. The defendant claimed that Dr Wilkinson had impliedly assigned her prior works to the defendant to the extent they figure in the new works, and that the defendants were free to exploit the new works. ${ }^{134}$

The court ruled out the implication of an assignment of Dr Wilkinson's prior works, and held that only a licence may be implied. ${ }^{135}$ The question arose as to the extent of this implied licence. The court observed that the proper place to consider the scope of the implied licence is the very agreement into which the term is sought to be implied. The court found that the defendant was to have its own copyright in all the new material that was created as a result of this agreement and the rights of the defendant in this regard were unfettered. Nothing in the agreement contemplated any manner of control or veto of the defendant's rights with the new works. The court found that at a minimum, any implied licence must not fetter the defendant's exploitation of the rights in the new works. ${ }^{136}$ It followed, the court further held, that the defendant could exploit the new works for other diseases, and in other jurisdictions, even if these possibilities were not specifically discussed. In keeping with the express terms, the court held that the implied licence must be irrevocable, ${ }^{137}$ royalty free, ${ }^{138}$ and can be sublicensed or assigned together with the defendant's copyright. ${ }^{139}$ The court also held that if the defendant provided services in competition to Dr Wilkinson, there was nothing in the

\footnotetext{
134 ibid [3]-[6], [56]-[60].

135 ibid [79]-[80], [89].

136 ibid [92].

137 Since it is a contractual licence, it is unsurprising that it is irrevocable.

138 The judge could have held that the fee paid for the creation of the commissioned works also covered fee for the implied licence of Dr Wilkinson's previous works, and for such implied licence to be sub-licensed and assigned. Royalty-free gives the impression of an implied bare licence, which it was not.

139 Wilkinson (n 133) [95].
} 
agreement that could stop it; nor could Dr Wilkinson be stopped from using Wilkinson Variant in any manner. ${ }^{140}$

All these conclusions arose from what the parties had bargained, which was to give the defendant the ownership of copyright in the new works created due to the collaboration with Dr Wilkinson. Having bargained thus, Dr Wilkinson could not assert her own copyright to hold back the defendant's copyright. In coming to this conclusion, the court declared the implication of terms to be 'reasonable and equitable, necessary to give the contract business efficacy, clear and does not contradict any express term of the contract', more as a conclusion, than in discussion. ${ }^{141}$ It is evident that the court was analysing the express terms closely, rather than trying to achieve what was necessary for business efficacy.

In conclusion, when implying a consent-based copyright licence into a contract, courts analyse the knowledge of the parties as to the bargain they have entered into, rather than their perception of the nebulous concept of business efficacy. Acknowledging that this is what the courts do, will make the reasoning in these cases better connected with the result, than if the courts were to simply state business efficacy as an overarching reason.

To complete the picture, courts also look at the surrounding circumstances in which the agreement is made, which brings us to the discussion below.

\section{Knowledge of the surrounding circumstances}

This part focuses on all facts and circumstances within the knowledge of the copyright owner that should be considered when she engages in the positive and the neutral act. This could take the form of what the parties depose as being within their actual knowledge. However, if

\footnotetext{
140 ibid [96].

141 ibid [92].
} 
it is an evolved market, the courts might regard that a copyright owner who operates in such market ought reasonably to have a minimum level of knowledge of the market and its trade practices. ${ }^{142}$ If the product incorporating the copyright work is highly specialised, the product knowledge may also be considered.

The effort through the discussion below is to show that the courts cast their net to capture a broad array of knowledge within this criterion. Therefore, it is difficult to say that the courts only try to do the minimum necessary for business efficacy or that such broad array of knowledge is so obvious that it goes without saying.

I begin the discussion with Beck, where the actual knowledge of the copyright owner came into focus. Although both Blair and Stovin-Bradford rely on the decision in Beck, ${ }^{143}$ the facts in Beck that were different need to be considered. The claimant in this case was an architect engaged to prepare plans to build over a piece of land. The claimant was aware that after the planning permission was obtained, the land had been put on auction stating that fully approved plans were available for inspection. In addition, the purchaser at the auction (first defendant) initially did consult the claimant to have detailed drawings drawn, only to decide not to engage them due to his fees. ${ }^{144}$ When the building was built according to the claimant's plans, he sued for infringement.

The court concluded that there was an implied licence in favour of the previous owner who commissioned the drawings. As to whether such licence extended to the subsequent purchasers. The judge stated that when the land owner sold her land and held out to the

\footnotetext{
${ }^{142} \mathrm{~A}$ trade practice is a practice which has not yet reached the stage of being recognised as a custom, but can be considered as background information for a contract. See Chapter II, section 2.1.2 above. For discussion on licences implied by custom, see Chapter V below.

143 [1963] FLR 298.

144 ibid 299-300.
} 
purchaser that plans had been approved and showed the plans, then with the sale of the land, a licence must be implied in favour of the purchaser to use the plans. The judge rightly pointed out that this assumed in the first place that the licence which the original owner of the land held, was itself assignable. ${ }^{145}$ The judge however, did not speak of the specific knowledge of the claimant regarding the sale of the land, although he recorded evidence to this effect. ${ }^{146}$ The judge simply concluded that having commissioned the plans and obtained the permission, the original owner of the land should also have the right to assign the use of the plans. ${ }^{147}$ Nevertheless, the specific knowledge of the claimant as to the sale of the land is likely to have influenced the judge, making it possible to hold the implied licence assignable to the purchaser from the original owner.

Can a court regard that an architect ought reasonably to know that the land for which she draws plans can be sold by the land owner, it being the nature of the market the architect operates in? The conclusion in Blair, that the assignability of the implied licence to the future purchasers of land arises out of the payment of RIBA scale fee, is unsatisfactory. In addition to knowing that the purpose of obtaining the planning permission is to build accordingly, the architects ought reasonably to know that planning permission increases the value of the land to the future purchasers. On this view, the claimant in Blair would have had the knowledge that the original land owner would sell the land and that the subsequent owner would have the use of the plans. This may have influenced the decision in Blair, although the judges do not articulate it expressly.

\footnotetext{
145 ibid 303.

146 ibid 300.

147 ibid 305.
} 
Another peculiarity about the market concerning land development is that planning permission runs with the land. ${ }^{148}$ This principle must be within the knowledge of an architect as part of her profession. However, one cannot take this principle too far. Lord Kingarth cautioned against it in Muir, where he observed that even though the planning permission runs with the land, a copyright licence to use the plans should not be regarded as similarly attached to the land. If that was the case, an implied licence would also inure to the benefit of any purchaser of the land, regardless of her contractual relationship or the lack thereof, with the architect. ${ }^{149}$ In Lord Kingarth's view, Blair concluded that the licence was assignable only because it had been assigned when the land was sold. If no such sale had occurred, the use of the plans could not have been assigned, even if the planning permission itself ran with the land. ${ }^{150}$ Nevertheless, Muir drives home the point that in an appropriate case, the knowledge of the architect that the planning permission runs with the land can be considered.

Another factor that the courts can consider is the evidence as to the normal fees a person may charge in the respective industry for her services, in the absence of a standard scale

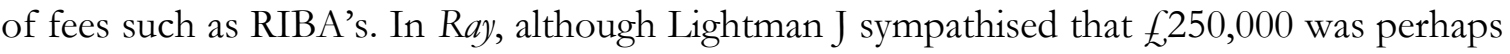
a high price to pay, he held that it did not in itself mean that Classic FM had wider rights in relation to the catalogue Ray had created. The court could have sought evidence of what in the industry would be regarded a reasonable fee for the work Ray performed. Evidence of Ray's pay in other assignments may also have been considered to assess normal fee. If he was being so clearly overpaid, then the higher fee may have represented wider actions which Classic FM could have engaged in, in respect of the catalogue. Also, the industry practice of a

\footnotetext{
148 Town and Country Planning Act, 1990, s 75, read with Law of Property Act, 1925, s 62.

${ }^{149}$ Muir (n 124) [14].

150 ibid [20].
} 
broadcasting station engaging consultants like Ray, especially of content that could be of potential interest internationally, could have also been considered, to ascertain the scope of the licence for Classic FM.

A good example of a specialised product and the knowledge as to the market in that product is Clearsprings Management Ltd v Businesslinx $L t d{ }^{151}$ In this case, the claimant (CMS), commissioned the defendant (BL) to create a software for its use in relation to asylum seekers. ${ }^{152}$ It was common ground that BL owned copyright in the software. However, CMS argued that BL had impliedly assigned the copyright in the software to CMS, or at least an exclusive licence for CMS to use it. BL on the other hand argued that CMS only had a nonexclusive licence to use the software, and such licence was not assignable, nor could it be sublicensed. ${ }^{153}$ The court found that BL had used its generic code to create the software, which BL must be able to use when working on other third party projects. ${ }^{154}$ Assigning the software therefore, would prevent BL from using this code which it legitimately owned and used even before BL's engagement by CMS, and therefore, a non-exclusive licence would suffice. ${ }^{155}$

The fact that software developers use certain generic code to bring about usual routines and operative procedures in a software was taken to be a trade practice, which provided the background information as to the performance of this contract. On the evidence available, the court held that such trade practice must have been within the knowledge of both parties. ${ }^{156}$

\footnotetext{
151 [2005] EWHC 1487 (Ch).

152 ibid [3].

153 ibid [6].

154 ibid [43].

155 ibid [48].

156 ibid [39].
} 
To conclude, given the breadth of knowledge the courts take into account in deciding the scope of the implied licence, it is difficult to say that they are only achieving the minimum necessary for business efficacy, or the most obvious result. Thus, analysing the case law as to the knowledge of the copyright owner as to the surrounding circumstances can make these decisions more transparent in showing the actual reasons for the courts to arrive at their conclusions, better than a mere assertion of the tests of business efficacy or obviousness.

\subsection{Copyright Exploitation Contracts}

The bulk of creative work takes place spontaneously, and not as a result of commissioning. For example, a fiction writer writes a novel at her own time, as her inspiration guides her. But these authors might still wish to exploit their work. They might approach a publisher in the respective creative industry, ${ }^{157}$ with their work, and if negotiations succeed, enter into a contract to exploit their copyright. ${ }^{158}$ Depending on the creative industry, these contracts can take many forms, including licensing or assigning of certain rights in the current works, or of future works for a defined period of time or a defined number of works, and the like. ${ }^{159}$ It is more likely than not that in these agreements copyright ownership and any provision for licensing are expressly provided.

If they do not so provided, I propose to first assess whether an assignment or a licence must be implied (contract stage), and if a licence must be implied, then ascertain the extent of

\footnotetext{
157 The term 'publisher' is used in a generic sense here. These include book publishers, academic journal publishers, newspaper and magazine publishers, music publishers, record companies, film producers and broadcasters.

${ }^{158}$ It is possible that a publisher might commission a work (e.g., biographies, translations), which must be assessed as commissioning contracts.

${ }^{159}$ For example, it is more common for music industry to have exclusive songwriter agreements whereby a songwriter assigns her rights in her present and future works; and for recording contracts to require exclusive licences from the artists for their current and future works for a term or by the number of works. Gillian Davies, Nicholas Caddick and Gwilym Harbottle, Copinger and Skone Janes on Copyright (17 th edn, Sweet \& Maxwell 2016) paras [26-96], [26-109].
} 
the licence (licence stage). Although in most cases discussed below, the courts have not insisted on the compliance with either the business efficacy or the obviousness test, applying the same methodology and framework for these contracts as for the commissioning contracts can bring greater clarity to the courts' reasoning.

\subsubsection{Contract stage}

As discussed above, contract stage determines whether the eventual contract becomes an assignment or a contractual licence. It helps to understand why the contract stage was necessary in commissioning contracts, to ascertain the role of the contract stage in copyright exploitation contracts.

Commissioned works owe their existence to the act of commissioning. In other words, the commissioned work is created responding to the request of and/or to the specification of the person commissioning. The commissioner plays a crucial role in determining whether the contract eventually becomes an assignment or a contractual licence. Ray's example indicates that the circumstances requiring an assignment to be implied include those where the commissioner has provided her own property to be worked on (e.g., a trade mark or a design), or some of her employees work with the copyright owner as joint authors. In effect, these are the situations where the commissioner seeks a highly customised work from the copyright owner, to meet the specific needs of the commissioner. This level of involvement in the work created is only possible in a commissioning contract. This is why contract stage is crucial in a commissioning contract.

In copyright exploitation contracts, on the other hand, copyright works are not created in response to the request of another person. The copyright owner creates works in her own time, and approaches the publisher for publication. The involvement of the publisher in publishing the work is not comparable to the involvement of a commissioner in having a work created. Nothing stops a publisher from seeking an express assignment. However, if the 
contract is silent on this issue, the cases where a court might decide to imply an assignment would be very rare. Even if the publisher needs to exclude the author herself from exploiting the work, or where the publisher needs her own right of action to sue for infringement against third parties, implying an exclusive licence will be sufficient. There have been no cases in the UK dealing with the question of whether an assignment or a licence should be implied into contracts other than commissioning contracts. If a case does arise, by analogy, Ray principles can still be applied to ascertain the mutual control over the copyright work sought by each party. Largely, therefore, the contract stage is resolved by implying a licence.

\subsubsection{Licence stage}

Having settled that a licence is to be implied, this section deals with how we may determine the extent of the licence. For the same reasons as the commissioning contracts, I argue that the framework proposed in Chapter II should be applied.

\subsubsection{Positive act}

The positive act of enabling the work to be accessed by the publisher, may happen in different ways depending on the kind of exploitation contract the copyright owner enters into. If a copyright owner has an ongoing publishing relationship, (e.g., a songwriter) she might send the work as and when it is ready. If the copyright owner is a relatively new entrant into the market, she might simply send the copyright work speculatively, and wait for it to be accepted for publication. ${ }^{160}$ If a contract follows, there is normally no issue with sending the work ahead. However, issues sometimes arise as to how the positive act should be construed.

\footnotetext{
160 A publisher may insist on a literary agent to submit books. See <https://www.penguinrandomhouse.co.uk/work-with-us/authors-agents/GettingPublished/>, accessed 30 July 2016.
} 
In Confetti Records $v$ Warner Music $U K L t d,{ }^{161}$ the claimants (the author and a small record label) owned the copyright in the song and the record of 'Burnin', which had become very popular in their genre of UK garage music. ${ }^{162}$ The defendant, a bigger record company, 'discovered' them and wanted to include 'Burnin' in an album that the defendant was going to release. ${ }^{163}$ Negotiations ensued, and all the communications and the deal memo setting forth the important terms were expressly 'subject to contract'. ${ }^{164}$ The deal memo sought the claimants to sign it and return it with the original cleared track. The claimants signed the deal memo, and returned it with the original cleared track as requested, and an invoice for the amount of the advance $\left(f_{1}, 500\right)$, stating that the invoice was for a non-exclusive licence granted for three years. ${ }^{165}$ The defendants went ahead to use the track in the album and prepared for its release. The claimants had tried to communicate to the defendants subsequently that they wanted to refuse the inclusion of the track in the album, but this communication did not reach the defendant before the album was ready. ${ }^{166}$ The question arose as to the effect of the claimants sending the signed deal memo, the cleared original track and the invoice.

The court held that since the deal memo was expressly subject to contract, signing it and returning it did not bind the claimants. However, the sending of the track and the invoice became an offer by the claimants in a unilateral contract, which could be accepted by

\footnotetext{
161 [2003] EWCH 1274 (Ch).

162 ibid [1]-[6].

163 ibid [10].

164 ibid [13], [17].

165 ibid [17]-[20].

166 ibid [22]-[37].
} 
performance of the contract by the defendant, which is to include the track in the album. ${ }^{167}$ This means that the positive act of sending the track under these circumstances became part of an offer. In this sense, the positive act is much more significant than simply signalling that the initial act of granting a licence had begun, as in bare licences, or being part of the performance of the contract, as in commissioning contracts. Indeed, in this situation, the acceptance of the positive act created a contract.

However, it does not always follow that when authors send their work speculatively, they necessarily make an offer. They could be making an invitation to offer, which could be responded to by the publisher by making an offer of the terms of publication. The difference in Confetti was the backdrop of negotiations between the parties that were already underway, and in final stages of acceptance. ${ }^{168}$ In any event, cases like Confetti demonstrate the need to be aware of the positive act and its effects.

\subsubsection{Neutral Act}

As described in case of commissioning contracts, the neutral act in copyright exploitation contracts too is conditional on the licensee performing her part of the bargain. This may be a payment or other conditions, as the cases below indicate.

In Redwood Music Ltd v Chappell Co $L t d,{ }^{169}$ the author of the song 'Zing' had originally assigned the song to a publisher, who had licensed it to the defendant. However, due to the operation of s 5(2) proviso of Copyright Act, 1911, the assignment to the original publisher had become void, and the copyright had reverted to the heirs of the author. The heirs of the

\footnotetext{
167 ibid [100], [109].

${ }^{168}$ The court held that the 'subject to contract' label was impliedly overridden by the claimants' conduct. ibid [100].

169 [1982] RPC 109.
} 
author finally assigned the remaining term of the copyright to the claimants. Seeing that the defendants were continuing to exploit the song even when the copyright had reverted, claimants sued them for infringement. However, during the period of exploitation, the heirs of the copyright owner continued to accept royalties, knowing that the royalties were for such exploitation. ${ }^{170}$ The court therefore, held that the acceptance of the royalties meant that the defendants were impliedly licensed to continue their exploitation. ${ }^{171}$

Since the neutral act was conditional on the royalties being paid, accepting royalties meant that the condition had been fulfilled, thereby continuing the neutral act. Further, the heirs of the author had the accompanying knowledge as to what the royalties were for, which enabled the continuance of the implied licence. Therefore, being sensitive to a conditional neutral act can explain the reasons for the courts' conclusions.

The neutral act can also be conditional upon something other than a payment. In Sawkins $v$ Hyperion Revords Ltd, ${ }^{172}$ the claimant, Dr Sawkins had created new editions of the compositions of a $17^{\text {th }}$ century French composer by name Lalande. Dr Sawkins had agreed with the conductor of an orchestra which was going to perform it, that a record should be produced of it. The conductor had identified the defendant to record the performance. ${ }^{173}$ Before the recording took place, Dr Sawkins sent the draft of a recording agreement, detailing his charges to provide the music, and had made it clear to the defendant that he was asserting his copyright and he be paid royalties. The defendant had refused and never signed the

\footnotetext{
170 ibid 120-23, 128.

171 ibid 128-29

172 [2004] EWHC 1530 (Ch).

173 ibid [9].
} 
agreement. ${ }^{174}$ Having reached a deadlock, the recording session was at risk. Upon the assurance of the conductor, Dr Sawkins allowed the recording to take place, but made it clear on the invoice for his charges of recording that the music should only be used for the recording, and no further use was permitted. ${ }^{175} \mathrm{He}$ intended the conditions stated in the invoice to be followed. However, the defendant went ahead to use the recording to release a CD. Dr Sawkins sued for infringement, and the defendant claimed an implied licence, since Dr Sawkins had permitted the recording to take place. The court held that the condition stipulated in the invoice made it clear that there was no licence for any purpose other than for recording, and therefore no implied licence could come into existence. ${ }^{176}$

The point to note here is that initially, the neutral act of standing back when the recording took place was only to create a recording and not to release CDs. This made the neutral act partial, in that the neutral act did not continue for anything other than the act of recording itself, such as releasing CDs. Since the defendant released CDs, no neutral act, and therefore no implied licence extended to such act.

In Film Investors Overseas Services $S A v$ The Home Video Channel Limited, ${ }^{177}$ the claimants who were owners of copyright in certain films, had licensed the defendant broadcaster to broadcast the films only in the UK. However, despite knowing that the defendant was broadcasting the films abroad, claimants did not take action for a length of time. Not insisting on a strict compliance with the condition of the neutral act that the broadcast could only be within the UK resulted in the court finding acquiescence against the claimant. Thus, being

\footnotetext{
174 ibid [77]-[79].

175 ibid [80].

176 ibid [82]-[83].

177 [1997] EMLR 347
} 
sensitive to the nuances of the neutral act can make the reasons given by the court more understandable.

\subsubsection{Knowledge of the copyright owner}

Like in the case of commissioning contracts, in copyright exploitation contracts too, at the license stage, the knowledge of the copyright owner of what is in the bargain and its surrounding circumstances must be considered. This knowledge holds the key to the extent of licence granted.

In Grisbrook v MGN Ltd, ${ }^{178}$ the claimant was a freelance photographer, and the defendant, was a publisher of many newspapers. There was no written agreement that governed the relationship between them, but the claimant used to supply photographs that he had taken of celebrities to the defendant. ${ }^{179}$ The trade practice was that many photographers would submit their photographs, and the relevant editor would choose a photo and publish it. It was up to the photographer who took the photo to see the paper the next day, and claim the price, which was typically a standard rate. ${ }^{180}$ It was also a trade practice of newspapers that unused photographs would go into a picture library, which the defendant could use in its future

publications. ${ }^{181}$ However, the defendant placed the back issues of the newspapers carrying claimant's photographs on its websites, and made them commercially available for purchase by the public. The claimant claimed this to be an infringement of his copyright since his original licence did not extend to the defendant exploiting his photographs in this manner.

\footnotetext{
178 [2009] EWHC 2520 (Ch).

179 ibid [2]-[4].

180 ibid [5]-[6].

181 ibid [7]-[8].
} 
The court held that it must be for the defendant to justify in the absence of express terms, the basis for extending the licence to cover what would otherwise be separate acts of infringement. The court held that as far as the compilation of the database was concerned, the defendant did have an implied licence to put the claimant's photographs to this use. However, to the extent that the photographs appearing in the back issues of the newspapers were archived and exploited through websites, it amounted to a different kind of operation which was not contemplated at the time when the licence was granted; nor was this manner of exploitation known to the claimant at the time he permitted his photos to be used in the newspapers. The court therefore, concluded that the claimant's copyright was infringed. ${ }^{182}$

Although in Grisbroook there was no express agreement, the discussion of the knowledge of the copyright owner as to what is normal exploitation of his work was far more nuanced than in Barrett $v$ Universal Island Records Ltd, ${ }^{183}$ where there was an express contract. The court did not extend the normal exploitation to simply all forms of exploitation that the newspaper industry is capable of; it rather it limited to what the copyright owner knew would be normal at the time he granted the licence, keeping in mind the practices of the newspaper industry.

\subsection{Consumer contracts}

Consumer contracts are contracts for the sale of products incorporating a copyright work. ${ }^{184}$ These contracts normally come into existence after a copyright exploitation contract. The purpose of a copyright owner entering into a copyright exploitation contract is so that the final

\footnotetext{
182 ibid [65].

183 [2006] EWHC 1009 (Ch). See Chapter III, section 1.3.3 above.
}

184 This part adopts the definition of a consumer under the CRA, s 2(3), which defines a consumer as an individual acting solely or mainly outside her trade or profession. Section 1(1) extends the Act to goods, services and digital content. 
product incorporating the copyright work (e.g., books or CDs) may be sold in the massmarket. When the publisher sells these products to a distributor or a wholesaler, the latter only receives a limited licence to issue copies of the work to the retailers. A consumer contract is the final contract of sale between the retailer and the consumer. The following paragraphs examine what it means to deal with the contract stage and the licence stage in these contracts.

\subsubsection{Contract stage}

The sale of products incorporating copyright to a consumer does not under any circumstances warrant implying an assignment of copyright into the contract of sale. Apart from the practical impossibility of being able to impliedly assign copyright to every consumer contract, the consumer contracts are also in standard form, denying to consumers the ability to individually negotiate the terms. Therefore, the contract stage in consumer contracts is always resolved in favour of a non-exclusive licence.

\subsubsection{Licence stage}

The copyright owner in the work incorporated in the goods sold reserves to herself all rights in the copyright. The circumstances where a licence may be implied are very limited. The act of sale of the products incorporating the copyright work is the positive act, since this is the act that provides access to the copyright work to the consumers. Once the sale is complete, the copyright owner standing back and not interfering with the use of the work is the neutral act. Regarding the knowledge of the copyright owner, there is no need to discuss the knowledge of the bargain, as it is a standard form contract and copyright owner herself decides those terms. Therefore, the only variable will be the knowledge of the circumstances, which, to a limited extent, can influence the scope of the licence, if at all a licence can be implied.

Consumer contracts provide very little room for implying a licence. However, most uses which consumers need to make of the goods incorporating copyright work do not 
interfere with the copyright owner's exclusive rights - such as reading a book or listening to music or watching a DVD one buys. When a use does interfere with the exclusive rights, the assessment will be whether a copyright owner, given the circumstances, has it within her knowledge or contemplation that such use can be made.

For example, in Roberts $v$ Candiware $L t d,{ }^{185}$ the question was whether the sale of a knitting pattern book entitled its consumers to use the patterns to make knitwear for commercial purposes. ${ }^{186}$ The court held that the consumers could only use the knitwear designs for personal purposes, and not for commercial purposes. ${ }^{187}$ The very purpose of the copyright owner creating a pattern book is for the consumers to make personal use of them. As such, for this kind of book, implied with it is a licence to the consumers that they can adapt the two-dimensional designs to three-dimensional knitwear. Making a commercial use of such knitwear is not within the contemplation of the copyright owner, and therefore the implied licence does not extend to such use. This kind of limited licence may extend to any pattern book (e.g., embroidery) or craft book.

\section{Conclusions and Connections}

This Chapter discussed consent-based implied contractual licences by analysing cases at the contract stage and the licence stage, and by rationalising the case law at the licence stage with the framework proposed for implying a consent-based copyright licence, namely the positive act, the neutral act and the knowledge of the copyright owner. In bare licences in Chapter III, the knowledge of the copyright owner was the actual knowledge of the specific circumstances.

\footnotetext{
185 [1980] FSR 352.

186 ibid 354.

187 ibid 354-55.
} 
In contractual licences however, we saw that the knowledge of the copyright owner can also include factors that ought reasonably to have been within the copyright owner's knowledge. The discussion of different types of contracts from bespoke commissioning contracts to standard form consumer contracts revealed that the knowledge of the copyright owner as to the surrounding circumstances becomes less significant.

In Clearsprings, the court considered the knowledge of a common practice for software developers to retain their right to use the generic code. In Grisbrook, the court considered the knowledge of the normal practice of newspaper industry. However, if these practices are consistently followed, but not within the actual knowledge of the party claimed to be subject to it, it is only possible to rely on such practice if it has become a custom within the respective industry. This is the focus of Chapter $\mathrm{V}$ below, where a practice that might originate consensually, may become an objective standard in an industry, claiming the status of a custom.

Consent-based implied contractual licences consider not only the factors within the actual knowledge of the parties, but also those within their contemplation. How far does the contemplation extend? What if the goods incorporating the copyright work need to be repaired, and such repair involves copying the underlying copyright designs? The fact that such goods, especially items of machinery require repair is within the contemplation of the copyright owner. But classifying it under consent-based contractual licence might push the limits of consent. It may be more appropriate to imply a licence based on public policy, rather than consent; the policy being to protect the licensee's rights to extend the life of the products she purchases, by repairing it. This is the focus of Chapter VI below.

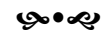




\section{Licences Implied by Custom}

This Chapter concerns licences implied based on a custom. ${ }^{1}$ As discussed in Chapter II above, a course of dealing or a line of conduct becomes a custom because the members of the relevant trade, business or profession engage in it voluntarily, repeatedly, consistently and universally in such a way that they begin to recognise it as binding. ${ }^{2}$ Therefore, it is not the court, ${ }^{3}$ but the voluntary conduct of a community that gives rise to a custom. Whilst in Chapters III and IV, the basis of implying a licence was the consent given voluntarily by one person, namely the copyright owner, in this Chapter it is the consent of a community due to the voluntary conduct of the members of the community. The similarity between the consent-based implied licences and the custom-based implied licences is that there is an identifiable positive and a neutral act. In consent-based licences, the courts are required to ascertain to a larger extent the actual knowledge of the copyright owner (bare licence), and to some extent also what the copyright owner ought reasonably to know (contractual licence), as to the circumstances. However, in this Chapter, the courts will impute the knowledge of a practice which has become a custom.

The knowledge of a custom can be imputed to the copyright owner whether a licence in question is a bare or a contractual licence. The criteria that go into proving the existence of a custom are independent of the existence of a contract, although many of the customs challenged in a court arise within a contractual context. Therefore, a custom can be the basis for implying a bare licence as well as for implying a term/licence into a contract. ${ }^{4}$ For example,

\footnotetext{
${ }^{1}$ The terms custom and usage are used interchangeably. See Chapter II, section 2.1.2.

2 ibid. It was also discussed that such binding nature makes a custom a source of power, which can serve as the basis for implying a copyright licence. See also Chapter II, Section 3.2.2.

${ }^{3}$ Cunliffe-Owen v Teacher and Greenwood [1967] 1 WLR 1421, 1438.

${ }^{4}$ See Chapter II, section 3.2.2.
} 
when an academic sends the manuscript of an article to a journal, the usage within the academic publishing trade enables implying a licence in favour of the editor to make copies of the article for peer review. No contract would have come into existence at that stage, but only a bare licence implied by custom.

A custom must first be established for it to be the basis for implying a bare licence or a term within a contract. Although it does not take a judicial decision to establish a custom, courts have developed criteria for proving the custom when its existence is challenged. Section 1 will discuss these criteria. Section 2 contextualises the discussion to copyright law, and addresses firstly, the scepticism that certain scholars have expressed as to the ability of stronger players in copyright industries to establish and perpetuate customs to their sole advantage, leading to an imbalance in the application of copyright law. This section discusses ways of addressing such imbalance, which also helps further refine the main criteria identified in section 1, to the copyright context. Secondly, this section discusses cases where a custom was pressed into service before a court as the basis for implying a copyright licence, in the light of the main and the refined criteria. Section 3 provides conclusions, and links this Chapter with the upcoming Chapters.

\section{Establishing a Custom}

Courts are categorical that it does not need a court of law to establish a custom. A custom is binding on the parties irrespective of any judicial decision. ${ }^{5}$ Courts further observe that if a custom had to be sanctioned by a court, 'a practice so obviously universally accepted and acted on as not to be challenged could never be a usage. ${ }^{6}$ However, courts have identified certain

\footnotetext{
${ }^{5}$ Kleinwort Benson Ltd v Lincoln City Council [1999] 2 AC 349, 394; Goodwin v Roberts (1875) 1 App Cas 476 (HL).

${ }^{6}$ Cunliffe-Owen (n 3) 1438.
} 
criteria to prove the existence of a custom, when parties challenge its existence. The recognition of a custom by a court is valuable in that it is conclusive in establishing the custom. ${ }^{7}$

\subsection{Criteria for Proving a Custom}

To ascertain whether a person has consented for her copyright to be used, one must ascertain the person's relevant conduct and her knowledge. ${ }^{8}$ To ascertain whether a community as a whole has voluntarily consented to a practice, as explained in Chapter II, the framework for establishing consent is inadequate. Instead, the criteria identified by the courts for the establishment of a custom more appropriately fit our purpose here. In this vein, commentators and judges agree that the minimum criteria necessary to establish a custom are that a custom must be certain, notorious and reasonable. ${ }^{9}$ Some commentators also insist that a custom should not be contrary to law and should be recognised as binding. ${ }^{10}$ The following paragraphs deal with each of these criteria.

\subsubsection{Certainty}

Certainty refers to the recurrence of the same pattern of behaviour in such a way that it becomes definable. In the leading case of Cunliffe-Owen v Teacher and Greenwood, the court had to ascertain the existence of a custom that the declaration of options could not be made by anyone other than a member of a Stock Exchange. ${ }^{11}$ Ungoed-Thomas J ruled that for a custom to be recognised by the courts, it must be certain in the sense that the practice is clearly

\footnotetext{
7 ibid.

${ }^{8}$ See Chapter II, section 3.1.1.

${ }^{9}$ Gerard McMeel, The Construction of Contracts: Interpretation, Implication, and Rectification (2nd edn, OUP 2011) para 12.11.

${ }^{10}$ Jack Beatson, Andrew Burrows and John Cartwright, Anson's Law of Contract (30"t edn, OUP 2016) 170-71.

11 Cunliffe-Owen (n 3) 1438.
} 
established. ${ }^{12}$ It means that the practice must be identifiable and uniform. ${ }^{13}$ These aspects are related in that if a conduct is repeated uniformly many times, then it becomes more identifiable. This does not mean that there must be complete uniformity in following the same conduct. In Sagar v H Ridehalgh \& Sons Ltd, a practice of an employer of a loom making certain deductions in wages for poor quality work of its employees had been followed in 85 percent of the looms in Lancashire. ${ }^{14}$ This was held to make the practice sufficiently certain.

\subsubsection{Notoriety}

Notoriety refers to the extent of knowledge that the members of the relevant community have of the usage. In Cunliffe-Owen, Ungoed-Thomas went on to say that a usage must be notorious 'in the sense that it is so well known in the market in which it is alleged to exist, that those who conduct business in that market contract with the usage as an implied term. ${ }^{15}$ Notoriety does not mean that the practice in question must be known to the whole world. Notoriety means that the practice must be well known in the context where it applies, and be capable of ready ascertainment by any person who proposes to enter into a transaction. ${ }^{16}$

The actual knowledge of the practice by the party need not be proved, so long as the practice is proved to be notorious. ${ }^{17}$ Knowledge of the practice is imputed to the person in such case. Underlying such imputation is the assumption that such person is a member of the concerned community (be it a trade, business, market or profession). It follows that if the lack

\footnotetext{
12 ibid.

${ }^{13}$ Wood $v$ Wood (1823) 1 C \& P 59; Beatson, Burrows and Cartwright (n 10) 170.

${ }^{14}[1931] 1$ Ch 310, 339.

${ }^{15}$ Cunliffe-Owen (n 3) 1438; Nelson v Dabl [1879] 12 ChD 568, 575.

16 Strathlorne Steamship Co Ltd v Hugh Bird \& Sons Ltd [1916] SC 134 (HL).

17 Cunliffe-Owen (n 3) 1439; McMeel (n 9) [12.21].
} 
of knowledge of a practice is because the relevant person is not a member of that community, then the practice is not binding on such person. As such, in Gabay $v$ Lloyd, ${ }^{18}$ a certain usage of Lloyd's Coffee House was held not to bind a party who was unaware of it, because he did not effect his insurance policies at the House, and was not a member of the community of insurers who did so. This reinforces the idea that the voluntariness in complying with a custom comes from being able to show that the person claimed to be bound by the custom was a member of the concerned community. The more representative a community is of the person claimed to be bound by its practices, the more likely the practices will be considered notorious, regardless of the person's actual knowledge. Unlike a consent-based implied licence, ${ }^{19}$ voluntariness of conduct is not is not assessed in relation to one person, but in relation to the whole community, vicariously representing such person.

\subsubsection{Reasonableness}

A custom must be reasonable. A custom is unreasonable unless it is fair and proper and is of such kind as to be adopted by 'reasonable, honest, and right-minded men'. ${ }^{20} \mathrm{~A}$ practice is unreasonable if it outrages justice and common sense. ${ }^{21}$ Unreasonable might also mean a practice that favours only one party. When considerable number of participants are part of one side of a particular business, they are likely to establish usages which act in favour of their side of the business. Brett J observed that: ${ }^{22}$

So long as they do not infringe some fundamental principle of right and wrong, they may establish such a custom; but if, on dispute before a legal forum, it is found that they are endeavouring to enforce some rule of conduct

\footnotetext{
18 [1825] 107 ER 927-28.

${ }^{19}$ See Chapters III and IV.

${ }^{20}$ Produce Brokers Co Ltd v Olympia Oil \& Cake Co Ltd [1916] 2 KB 296-97.

21 ibid 301.

22 Robinson v Mallett [1874-74] LR 802, 818.
} 
which is so entirely in favour of their side that it is fundamentally unjust to the other side, the Courts have always determined that such a custom, if sought to be enforced against a person in fact ignorant of it, is unreasonable, contrary to law, and void.

Courts regard a custom that is unreasonable to be unenforceable only if the party claimed to be bound by it was unaware of it. If both parties were aware of the custom, even if it is unreasonable, it can be enforced. ${ }^{23}$ The reason for this could be the courts' unwillingness to meddle with the private ordering that customs create within a community. This is problematic for two reasons: firstly, a mere awareness does not always mean that the party subject to an unreasonable custom had an opportunity to negotiate, especially given the reality of standard form contracts. Secondly, there is no reason to perpetuate an unreasonable practice simply because the party to whom it was unreasonable failed to negotiate and contract out of such practice, despite being aware of it.

Could there be a law prohibiting implying unreasonable customs into a contract? This takes us to the next requirement, the lawfulness of the custom.

\subsubsection{Not contrary to law}

Some scholars combine the requirement of reasonableness with lawfulness ${ }^{24}$ to the extent that reasonableness may be ingrained within the relevant laws. As argued above, due to the recognition of 'unreasonable customs' under certain circumstances, a second layer of scrutiny by law is welcome. Further, an assessment of lawfulness may encompass much broader policy objectives than reasonableness, making it a good additional benchmark.

Whether an unreasonable custom will also be found unlawful depends on whether there is a statutory or common law rule against the enforcement of such a custom. If a custom

\footnotetext{
${ }^{23}$ Perry v Barnett (1885) 15 QBD 388, 393; see also Cunliffe-Owen (n...) 1439.

${ }^{24}$ McMeel (n 9) paras [12.19]-[12.20].
} 
is found to violate a law, it will not be recognised, regardless of the knowledge of it by the parties to the transaction. Anglo-African Merchants Ltd $v$ Baylaey ${ }^{25}$ illustrates this point. It concerned a practice of insurance brokers who acted as the agents of the assured at the time of issuing the policy. But if a claim had to be made and the underwriters asked the brokers for a claim assessment report, the brokers would become agents of the underwriters instead. ${ }^{26}$ Megaw, J doubted the notoriety of the custom. ${ }^{27}$ However, he went on to state that even if the custom was well known, it would not be upheld if it contradicted the principle that an agent may not act for two principals at the same time whose interests conflict with each other, unless the agent had the explicit informed consent of both principals. ${ }^{28}$ Therefore, it may not have been a good argument on part of insurance brokers that the assured were aware of the custom and therefore, the custom should be recognised. Since the custom violated such a fundamental principle of law of agency, the court might still have not recognised the custom.

Other than the specific law addressing a situation (such as law of agency in AngloAfrican), is there a general rule against unconscionability, meaning a situation where one party takes advantage of or exploits the other due to their unequal bargaining power? Some commentators argue that there is such a common law rule, ${ }^{29}$ although the courts have been reluctant to recognise it as a general rule outside the specific statutory expression. ${ }^{30}$ Unfair Contract Terms Act, 1977, despite its title, does not address all unfair terms, but only the terms

\footnotetext{
25 [1970] 1 QB 311.

26 ibid 322.

27 ibid 323.

28 ibid 323-24. See North and South Trust Co v Berkeley [1971] 1 WLR 470, 482, 484.

${ }^{29}$ Patrick S Atiyah and Stephen Smith, Atiyab's Introduction to the Law of Contract (6 $6^{\text {th }}$ edn, Clarendon Press 2005) 300, 309-13.

30 National Westminster Bank v Morgan [1985] AC 686, 708 (per Lord Scarman). He was referring to statutes like Consumer Credit Act, 1974, and so on, which address unequal bargaining power.
} 
in a contract that exclude or restrict liability of one of the contracting parties under certain circumstances. ${ }^{31}$ Similar provisions in relation to consumer contracts are separately addressed in Consumer Rights Act, 2015. ${ }^{32}$

These statutes regard only certain kind of terms in a certain kind of contracts unconscionable. The applicability of these statues outside a contractual scenario is limited to the exclusion or restriction of liability for negligence in notices that may not form part of a contract. ${ }^{33}$ This does not include an unreasonable term implied by custom into a bare licence. Therefore, the courts may not have an all-encompassing power to scrutinise customs for unconscionability (and thus, unreasonableness).

\subsubsection{Recognised as binding}

The conduct should be shown to have been intended to have a legally binding effect, and the compliance with the conduct must have been the result of a belief in a legal obligation to do so. ${ }^{34} \mathrm{~A}$ custom should be distinguished from a practice which is followed as a grace or a matter of commercial convenience. In Stratblorne, the question was whether a practice of bulking the grains from their original sacs to large bins, transferring and delivering them in new sacs, was a matter of convenience of ship owners or an established custom. Upon evidence, the court confirmed that it was only a matter of convenience, and that the ship owners could adopt any

\footnotetext{
${ }^{31}$ UCTA deals with exclusion clauses relating to liability for negligence (ss 2, 3, 7), breach of terms implied into a contract by statutes such as sale of goods (ss 6,7) and breach of contract in standard form contracts (s 3).

32 Under CRA, s 2(3), a consumer is defined as an individual acting mainly or wholly outside his trade, business, profession or craft. It relates to goods, services and digital content. It also includes provisions dealing with exclusion clauses.

${ }^{33}$ UCTA, s 2; CRA, s 57.

${ }^{34}$ Beatson, Burrows and Cartwright (n 10) 170.
} 
other practice if found more convenient. ${ }^{35}$

Commentators observe that the clearest way of establishing the binding nature of a custom is to show that it has been enforced in a court, but this does not need to be so, since the courts have ruled that the binding nature of customs does not come from a ruling of the court. It is sufficient for a party to establish that a custom has been acted upon. In some cases, showing that a custom has been embodied in the code of conduct of a particular business, profession or trade, can be good evidence that the members thereof regard the code as binding. ${ }^{36}$ This brings us to the next section - how does one prove a custom.

\subsection{Proof of a Custom}

Courts insist on strict proof of each criterion, since repeated actions of a community must be proved for its consistency and universality. In Cunliffe-Owen, Ungoed-Thomas J noted that proving a custom is a mixed question of law and fact. ${ }^{37}$ Since a custom relates to a community, it must be proved by persons familiar with them; typically, the members of the community. It takes a substantial amount of evidence, including expert evidence to prove a custom. However, evidence as to a custom is not a matter of opinion, of even the most highly qualified experts; it must be of fact. ${ }^{38}$ Judges express concern that it is very rare that two witnesses give exactly the same account of a custom. Therefore, in Tucker $v$ Linger where the issue was the existence of an agricultural custom, Jessel MR noted that the evidence of a custom 'must be collected

\footnotetext{
35 Strathlorne (n 16) 137.

${ }^{36}$ Beatson, Burrows and Cartwright (n 10) 170.

${ }^{37}$ Cunliffe-Owen (n 3) 1238.

${ }^{38} \mathrm{McMeel}$ (n 9) [12.13].
} 
not from what the witnesses say they think the custom is, but from what was publicly done'. ${ }^{39}$

If not proved, a practice remains a 'trade practice', which is a custom in the making, but has not reached a stage where it is binding. It might assist in establishing the background of a transaction, but cannot be the basis for implication. ${ }^{40}$

\section{Customs in Copyright Law}

The previous section dealt with the criteria for proving a general custom before a court. This section moves on to the specific context of copyright law. Copyright landscape is fraught with vast inequalities amongst its stakeholders, ranging from copyright owners such as large multinational record companies to busking musicians, and users of content such as multinational film producers to individual consumers. If a custom is to be recognised, questions must be asked as to the way it is formed, how the community where it applies is defined and normatively, what purpose it serves. The possibility of dominant players in the market ensuring a self-serving practice, which is to the detriment of the other stakeholders, is followed consistently, and have the wherewithal to prove it as a custom before a court, cannot be ruled out. The way customs are formed and maintained could then perpetuate these selfserving practices.

This part begins by discussing these concerns, and analyses the extent to which the criteria identified in section 1 above address them. To the extent that these concerns are not addressed, the discussion goes on to refine the criteria so that we have a framework for custom-based implied licences specifically suited for the copyright context. The discussion

\footnotetext{
39 (1882) $21 \mathrm{Ch}$ D 18, 34.
}

${ }^{40}$ Richard Austen-Baker, Implied Terms in English Contract Law (Edward Elgar, 2011) para [5.01]. See Chapter II, section 2.1.2 above. The court accepted trade practices in Clearsprings Management Ltd v Businesslinx Ltd [2005] EWHC 1487 (Ch) and Grisbrook v MGN Ltd [2009] EWHC 2520 (Ch). 
then goes on to examine the few cases where UK courts have had an opportunity to consider licences implied by custom, and whether there are any causes for concern for adopting these customs as the basis for implying copyright licences in the light of the refined criteria.

\section{$2.1 \quad$ Some Concerns}

Jennifer Rothman has provided one of the most detailed analyses of the application of customs to copyright, although in the specific context of US law. Rothman argues from the perspective that in almost every case where the US courts have considered an industry practice, they have used it to reject a defence for infringement or have used it as a basis to find infringement. Very rarely, she says, the US courts have used an industry practice as a defence to copyright infringement. ${ }^{41}$ This Chapter, however, proposes to use a custom as the basis for implying a licence to deny infringement. The purpose for which this Chapter proposes to use a custom is therefore, different. However, Rothman's arguments that warn of certain pitfalls in the formation of a custom specifically in the copyright context, are worth considering.

Rothman argues that the courts in the US have given effect to customs indiscriminately, to the benefit of copyright owners, and to the detriment of all other stakeholders. She illustrates this with many examples. One such is the practice prevalent among certain media industries seeking copyright clearance of all content regardless of the proposed use being permitted by fair use exception, merely to avoid the risk of litigation. ${ }^{42}$ She cites cases where courts take cognisance of this practice, even in cases where fair use exception should have applied. ${ }^{43}$ She also gives examples of self-serving guidelines and best practices

\footnotetext{
${ }^{41}$ Jennifer Rothman, 'The Questionable Use of Custom in Intellectual Property’ [2007] 93 Va L Rev 1899, 1906.

42 ibid 1903-4, 1911-16.

${ }^{43}$ She cites Ringold v Black. Entertainment Television 126 F.3d 70, 73 (2d Cir. 1997), among others.
} 
applied by specific industries permitting the use of copyright works under very specific circumstances, in stark contrast to the general wording of the fair use exception, and the courts taking cognisance of those practices. ${ }^{44}$ She argues based on these examples that incorporating customs within copyright law does not produce optimal results because they are one-sided, leaning towards the more powerful copyright owners. She also argues that adopting a custom as a means of private ordering should not be preferred over public ordering by law, when there are public policy goals to be achieved. ${ }^{45}$ In conclusion, she proposes a normative framework to identify the customs that are worth adopting in copyright law. ${ }^{46}$

\subsubsection{Concerns already addressed in the UK criteria}

Not all of Rothman's concerns in relation to customs hold true before the UK courts, as explained in the following points:

- Rothman's definition of a 'custom' is very broad. She includes industry practices, community-developed standards of behaviour, common community practices, and practices dating from time immemorial. ${ }^{47}$ As discussed in section 1 above, the term custom has a technical meaning, and requires a high standard of proof. Therefore, not all that Rothman regards as custom may be a custom under the UK law. Many of them might stop at being trade practices qualifying as background evidence, and not a basis to alter legal obligations.

\footnotetext{
${ }^{44}$ Rothman (n 41) 1905-6, 1916-24. See also, Richard Epstein, 'Some Reflections on Custom in the IP Universe', (2008) 93 Va L Rev In Brief 223, where he disagrees with Rothman as to her examples.

${ }^{45}$ Rothman (n 41) 1907, 1947-67.

46 ibid 1908, $1967 \mathrm{ff}$.

47 ibid 1901, note 1.
} 
- Rothman points out the need for certainty in identifying a custom, ${ }^{48}$ and emphasises that the lack of certainty can lead to opportunistic use of customs. Again, certainty is a key aspect of proving a custom under the UK law.

- Built into proving a custom are the requirements that the custom be reasonable and be recognised as binding. Rothman's examples where a practice is one-sided or unduly favouring one party, may not pass the reasonableness test, if the person claimed to be bound by it was unaware of it. If a practice is adopted only for the convenience of avoiding litigation, it may not pass the test of being recognised as binding.

Thus, the UK law has pre-empted some of Rothman's concerns. However, the suggestions Rothman makes to improve the reliability of customs, which are not fully captured by the UK law, are discussed below.

\subsubsection{Concerns requiring refinement of the UK criteria}

Rothman identifies six factors in her framework to make customs more acceptable for adoption within copyright law. These factors can be distilled to three points, which I propose as further refinement of the main criteria discussed in section 1 above.

\subsubsection{Motivation}

Rothman says that the more normative and aspirational a custom is, the stronger the case for its adoption. ${ }^{49}$ She emphasises that if the motivation is merely to avoid litigation, then the case for recognising the practice as a custom should be weak. If the concern is to avoid practices adopted merely for convenience, the requirement of a custom being recognised as binding

\footnotetext{
48 ibid 1968.

49 ibid 1970.
} 
captures the motivational aspect to some extent. However, normative goals can go much further.

From the UK courts' perspective, building normative goals into a custom could be a good criterion to add, given the issues surrounding 'unreasonable customs' discussed above. ${ }^{50}$ It is difficult to see a normative goal that an unreasonable custom might achieve, except maintaining freedom to contract reflected in the parties choosing to knowingly abide by an unreasonable custom. However, if the circumstances show that parties did not enter the contract freely (such as in standard form contracts), and that there is a significant difference in their bargaining power, then there will be very little normativity in the motivation to support the custom. Even in the absence of a general rule on unconscionability, this criterion may be able to capture unreasonable practices, and prevent them from becoming customs.

\subsubsection{Impact of a custom}

Rothman argues that the more balanced the allocation of rights, the greater the suitability of the custom in the copyright context. ${ }^{51}$ This point returns to the reasonableness requirement of the UK courts. However, given the issue of unreasonable customs as discussed above, this requirement can serve as an additional pointer to the courts to ensure that the party with weaker bargaining power is not exploited simply because she is aware of an unreasonable practice. Further, normatively, copyright system is geared towards balancing the rights of the copyright owners with those of other stakeholders, such as copyright users and the public in general. It should not be possible to recognise a custom that goes against this objective. Therefore, this criterion is also worth incorporating within the copyright context.

\footnotetext{
${ }^{50}$ Sections 1.1.3 and 1.1.4 above.

${ }^{51}$ Rothman (n 41) 1976.
} 


\subsubsection{Representative nature}

The more the participation of all parties concerned in formulating these practices, the more the strength of a custom. ${ }^{52}$ Rothman says that copyright industries are given to ignoring the rights of weaker stakeholders, which can be avoided by requiring a custom to be more representative of all parties concerned. She also cautions against defining the community of operation of a custom too broadly, as potentially the whole world could be a community if a custom relates to popular content. ${ }^{53}$ This aspect is addressed to some extent in notoriety, in that the more representative a practice is of the person claimed to be bound, the more the likelihood of a finding of notoriety.

With specific reference to copyright law, given the inherent inequalities among the stakeholders, and the difficulties in defining the community within which a copyright custom may operate, this factor is worth incorporating. However, in principle, it should be possible to define a community broadly, if it can be shown that its participants have consistently followed certain practices. An example is the community of internet users engaging in consistent practices on the internet that can go on to become customs. ${ }^{54}$

With this in the background, I turn to consider the few cases in which the UK courts have addressed implying a custom-based copyright licence.

\subsection{Custom as a Basis for Implying a Copyright Licence}

We saw in section 1 above that a practice which has not become a custom can remain as a

\footnotetext{
52 ibid 1972-5.

${ }^{53}$ Jennifer Rothman, 'Why Custom Cannot Save Copyright's Fair Use Defense', (2008) 93 Va L Rev In Brief 243, 246.

${ }^{54}$ See Chapter VIII below.
} 
trade practice, i.e., a practice that constitutes the background knowledge of the concerned industry, and not in itself a basis for implying a licence. Chapter IV above referred to two cases ${ }^{55}$ where the court considered trade practices. The concern in this chapter is a step further from those cases, where the alleged practice is claimed to have become a custom, which is relied on to imply a licence.

Given the expense involved in proving a custom before a court, not many cases concerning establishing copyright customs have been litigated. Danowski v The Henry Moore Foundation, ${ }^{56}$ is one of those few, although implied licence was not directly at issue here. The well-known British sculptor, Henry Moore, partway through his career, established the defendant, a charitable company limited by guarantee, to which he transferred all his previous works. He also established a wholly owned subsidiary of the defendant, with which he entered into an employment agreement, and transferred to it all his tools of trade and work in progress. ${ }^{57}$ The employment agreement stated that the company was the owner of copyright in any work Moore created during the course of his employment. After his death, his daughter who inherited his assets, claimed that during his lifetime, Moore had retained what are called artist's copies of certain works, which is customary among sculptors, and that this custom should be read into his employment contract. As a result, she claimed that these artist's copies belonged to her, rather than to the defendant. ${ }^{58}$

Nourse LJ relied on the description of the custom of artist's copies from the trial records and described it as follows. When an artist creates a work that can be reproduced

\footnotetext{
55 Clearsprings (n 40); Grisbrook (n 40).

56 [1996] EMLR 364 (CA).

57 ibid 367.

58 ibid 368-70.
} 
(using say a mould for a sculpture, lithograph for a print, etc) the artist can declare it to be limited edition to a purchaser. If he does so, then he must limit the reproduction to the number declared. However, this is always subject to the artist's right to make two additional copies for himself, called artist's copies, for his own purposes. He may retain these for future reference, give them for exhibitions, or even sell them. ${ }^{59}$ Reviewing the evidence Nourse LJ held that although artist's copy convention was a practice amounting to a custom in the art trade applying between the artist and a purchaser of the limited edition work concerned, the evidence did not show that this practice was likewise followed between an employer and an employee. The expert evidence could speak only to the existence of the custom when the artist is self-employed, and any evidence as to the existence of the custom when the artist is employed was only a matter of opinion. Nourse LJ held such opinion to be inadequate to support the application of the custom to an employment relationship. ${ }^{60}$ He noted that the existence of a general custom in relation to 'a particular part of a trade does not cause it to become a general custom or usage of the trade generally. ${ }^{91}$

He also went on to hold that even if the custom was established between an employer and employee, such custom would be inconsistent with the express terms of Moore's employment agreement and its general tenor. ${ }^{62}$ By general tenor, Nourse LJ meant the employment agreement expressly vesting copyright with the company, read with the agreement selling his tools of trade to the company. He said that together they convey that Moore had transferred any artist's copies he had retained of his works. Nourse LJ did not have

\footnotetext{
59 ibid 371.

60 ibid 373-5.

61 ibid 375.

62 ibid 376. McCowan LJ and Thorpe LJ also agreed with Nourse LJ's decision. ibid 376-78.
} 
to consider what was in the agreement with the purchasers of the limited edition works, as these agreements would have been entered into by the company of which Moore was an employee, and not with Moore himself. Since the company owned copyright of all works Moore created during the course of his employment, if any artists copies were created, those should have belonged to the company, and not to Moore.

Although the court recognised artist's copy as a custom, it was not used as a basis for implying a term into Moore's employment agreement. Artist's copy convention emanates from the copyright ownership of the artist. As the owner of copyright in the works she creates, an artist is free to create any number of copies of her work. As the creator of the works, she also has the knowhow and the required material for reproducing the work. When she declares a work as limited edition, she places restriction on her ownership powers. In this case, however, Moore had transferred his copyright by way of an employment agreement with the company. Therefore, the only way to retain artist's copies was to argue that even after parting with the copyright, Moore had a licence implied by custom, to retain two copies of the works he created. However, such implied licence would have changed the very substance of the custom from a disability on ownership powers to one creating a privilege. Thus, the custom did not serve as a basis for implying a licence into the employment agreement.

However, Danowski is still a good illustration of how a custom applies in a copyright case, discussing in detail the evidence of the custom at the trial. ${ }^{63}$ Even applying the more cautious criteria that Rothman proposes above, the custom is representative of the parties sought to be bound by it, is balanced and is not motivated merely by convenience. Thus, the existence and maintenance of this custom stand on a firm footing based on the main and the

\footnotetext{
${ }^{63}$ Nourse LJ stated that the trial took twenty days and the trial judge's decision ran into 118 pages. ibid 368.
} 
refined criteria discussed above.

A custom must not violate the law. But a licence by definition, makes lawful what would otherwise be unlawful. ${ }^{64}$ Does this mean that a custom cannot make legal what would otherwise be illegal? Could a custom not permit the use of a copyright work, which if not for the custom, be an infringement? The High Court decision in British Leyland Motor Company Ltd $v$ Armstrong Patent Company Ltd, raised this issue. ${ }^{65}$ The question was whether there is a custom permitting the repair service providers to manufacture spare parts in advance of receiving orders. The court held that to recognise a custom to that effect is to 'permit infringement with impunity ${ }^{66}$ Some commentators understand this to mean that a custom cannot be relied on in defence of copyright infringement. ${ }^{67}$

This cannot be correct. When it is possible for an individual copyright owner to consent to specific copyright uses, a community of copyright owners can likewise consent to a specific use, if all other requirements of establishing a custom are satisfied, including those further refined in section 2.1 above. Commentators acknowledge older decisions that relied on licences implied by custom. ${ }^{68}$ Further, practices exist within the newspaper industry which may have become a custom, but these have never been litigated. For example, when a person sends a letter to the editor of a newspaper commenting on a matter published in that newspaper, a licence is implied by custom that the editor is permitted to publish the letter in

\footnotetext{
64 Thomas v Sorrell (1672) Vaugh 330, 351.

65 [1982] FSR 481.

66 ibid 493. For a discussion on the appropriate basis for implying a licence in this context, see Chapter VII, section 2.4.3 below.

${ }^{67}$ Halsbury's Laws of England, Vol 32, para 51

${ }^{68}$ Mary Vitoria, et al, Laddie, Prescott and Vitoria The Modern Law of Copyright and Designs (4th edn, vol 1, Lexis Nexis 2011) para [25-15], and the cases referred to are Merryweather v Moore [1892] 2 Ch 518; Lamb v Evans [1893] 1 Ch 218; Hall Brown v Iliffe \&o Sons Lrd [1928-35] MCC 88.
} 
the newspaper. These practices reveal that it is possible for a custom to be the basis for implying a copyright licence, so long as the custom is established in the manner required by the criteria.

An example where a newspaper custom was litigated is Express Newspapers plc v News (UK) $L t d .^{69}$ Here, a reporter of the plaintiff had managed to interview Ms Pamella Bordes, a person in public eye due to her relationships with persons in power. The reporter wrote up the story quoting extensively from the interview, which was published the next day. Having read the story in the plaintiff newspaper, the defendant also carried a story quoting extensively from the interview by the plaintiff's reporter. Ten days before the hearing, the defendant published a story based on an interview by its reporter with a member of the royal family, again quoting extensively from the interview. And the plaintiff, having seen the defendant's newspaper, published in its own newspaper a couple of days later its own story, but quoting extensively from the interview by the defendant's reporter. Both parties sued each other in different proceedings. ${ }^{70}$ The plaintiff complained of infringement, but defended itself based on a licence implied by custom in the newspaper industry, that a newspaper is allowed to pick up a story based on an interview published in another newspaper, and publish it in its own words in its newspaper. ${ }^{71}$

The court noted that upon publication of the defendant's interview with the member of the royal family, many other newspapers had picked up the story and had published it in their own words. Therefore, the court acknowledged that there may be a custom in the

\footnotetext{
${ }^{69}$ [1990] 3 All ER 376.

70 ibid 377-78.

71 ibid 383.
} 
newspaper industry to this effect, which could be proved at the trial. ${ }^{72}$ However, since the plaintiff had made contradictory claims in these two proceedings, based on the principle that a litigant cannot approbate and reprobate at the same time, the court dismissed the suit summarily. ${ }^{73}$ Had the plaintiff not raised these contradictory claims in these proceedings, this case may have gone to trial, where a custom permitting a newspaper to pick up stories from interviews reported in other newspapers, may have been established. Such custom could then have become the basis for implying a copyright licence.

Such custom, if factually proved to exist with certainty and notoriety, would have been regarded as reasonable. The court acknowledged the public interest in the need for not recognising monopoly in news, so that wider dissemination of news and information may be achieved. As such, the custom would have satisfied the aspirational motivation. It would have balanced the copyright owner's own rights against the consumers of news. Applying between actors within newspaper industry, this custom would have stayed true to the need for being representative within the industry.

A note of caution here is that newspapers are powerful users of copyright works. Not all their practices should be regarded a custom, as some practices may be singularly self-serving. In Banier v News Group Newspapers Limited, the plaintiff was a well-known photographer, who had taken photos of a member of the royal family. ${ }^{74}$ His agent had licensed its publication in a particular newspaper (which licence had been disputed in another proceeding). The defendant newspaper wanted to publish the photographs, but could not establish contact with

\footnotetext{
72 ibid. The court distinguished Walter $v$ Steinkopff [1892] 3 Ch 489, which had held that quoting from other newspaper reports was an unreasonable practice, on the basis that the newspaper industry has changed in the last 100 years and in any event, that case was not about quoting from the words of an interviewee.

73 ibid. 383-84.

74 [1997] FSR 812, 813-14.
} 
the plaintiff's agent in time to obtain the licence. The defendant published the photograph anyway. ${ }^{75}$ When sued for infringement, the defendant claimed that the practice among newspapers was always to obtain a licence beforehand. However, if it was not possible, given the tight deadlines within which newspapers function, there was a practice among newspapers to publish a photo which had already been published in another newspaper, and obtain a licence later. Lightman J held the practice to be clearly 'unjustified and unlawful'. ${ }^{76}$

This decision is correct based on both the general and the refined criteria above. Applying the general criteria, the custom would not have satisfied the reasonableness requirement. As for the refined criteria, the practice was clearly one-sided. Simply because a photographer had consented to her work being published by one newspaper did not mean that she had generally consented for all newspapers to publish it. Other than convenience of time management, the practice served no purpose. Even if it applied within the newspaper industry of which photographers are very much a part, in the formulation of this practice there was a disregard of the photographers' interests. Therefore, applying the refined criteria of the motivation, a practice of the kind in this case would not have become a custom.

\section{Conclusions and Connections}

This Chapter considered a copyright licence implied by custom. For the establishment of the custom, the main criteria as recognised under contract law and more refined criteria as appropriate for copyright were identified.

Courts look at communities for the operation of customs - such as trade, business or profession. Often, in modern times, it may not be possible to identify such communities,

\footnotetext{
75 ibid.

76 ibid 815.
} 
because their membership is too disparate. For example, if one were to consider a practice that applies to purchasers of machinery, the community to which such practice applies would be potentially quite large. Instead of defining communities, a better approach may be for the courts to categorise certain types of contracts to which certain common incidences apply. In the above example, in all contracts of sale of goods with limited life, the common incidence is that the goods will require repair at some point. To facilitate repair without infringing copyright in those goods, a licence must be implied. The justification for such implication is stronger for policy reasons than a custom. This leads us to the Chapter VI below, which considers policybased implied contractual licences.

It does not mean that customs are less relevant to copyright law. The formation of customs within a community is a constant inevitable process. With the interaction between different stakeholders over time, different practices come to be acknowledged, adopted, repeated and recognised as binding. It is possible that the existence of the digital environment over the last two decades has resulted in practices that meet the criteria for establishing a custom. Whether such customs might exist and how they may be used for implying a licence on the internet is discussed in Chapter VIII below.

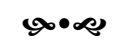




\section{Policy-based Implied Contractual Licences}

This Chapter focuses on cases where there is a pre-existing contract, and a policy-based licence is implied into such contract. To the extent that a contract exists, there is a certain voluntariness on part of the contracting parties in entering into the contract. To this extent, one might even identify the positive and neutral acts by the copyright owner in dealing with the copyright work. However, as stated in the conclusion to Chapter IV above, a consent-based licence is incomplete because the actual knowledge of the copyright owner might not extend to the situation being covered. In these circumstances, it is more appropriate to attribute the implication to the courts giving effect to public policy objectives than to the unexpressed joint intention of the parties. In this sense, the implication of a licence departs from a strictly consensual basis, and is classified as a policy-based implication.

Although the tests for implying a term in fact are also controversial, ${ }^{1}$ courts generally try to find legitimacy on the basis that they only give effect to the unexpressed joint intention of the parties, and that it is the contracting parties, and not courts, that make the contract. Underlying this manner of implication is the ideal of freedom of contract. However, scholars note that freedom of contract is an ideal rarely realised in practice, and that the process of contract formation cannot be relied upon to ensure that contract terms will be fair or efficient. ${ }^{2}$ Therefore, at common law, courts also imply a term into a contract to achieve broader policy goals such as fairness or efficiency, even if the term did not strictly represent the joint unexpressed intention of the parties. These are called terms implied-by-law. In Liverpool City Councilv Irvin, Lord Wilberforce described implying terms under different circumstances as shades in a spectrum, ${ }^{3}$ reinforcing a view that the courts find it an extension of their judicial function to imply terms not grounded in

\footnotetext{
${ }^{1}$ See Chapter IV, section 1.2 above.

2 P S Atiyah and Stephen Smith, Atiyah's Introduction to the Law of Contract (6 $6^{\text {th }}$ edn, Clarendon Press 2005) 156, 162.

3 [1977] AC 239, 253-54.
} 
the intention of the parties. As a vindication of courts' action, many of the terms implied by courts are now codified in a statute.

Some scholars express scepticism regarding courts giving effect to policy objectives, which they believe should traditionally remain the province of the legislature. ${ }^{4}$ As such, they regard statutes as the right source for implying a term by law, of which there are many examples. ${ }^{5}$ However, courts are closer to the reality of the circumstances requiring terms to be implied on a case by case basis, which the generalised view of a legislature might miss. Phang argues that even if statutes are the 'purest' source of terms implied by law, courts act as 'testing ground' for implying terms by law, and assist 'in the gradual (and ultimate) shift toward the legislative implication of terms'. ${ }^{6}$

From this point of view, turning to the copyright context, compulsory licences as contractual licences, should be less controversial because the public policy to be achieved and the circumstances of granting a compulsory licence are determined by the statute. But this Chapter deals with policy-based implied contractual licences, which are distinguishable from compulsory licences. To recapitulate the arguments in Chapter II above, ${ }^{7}$ firstly, the public policy goal to be achieved by a policy-based implied licence is determined by a court from an open-ended list, and not pre-determined by the legislature in a statute. Secondly, any person can approach the relevant authority for the grant of a compulsory licence. In this sense, the competent authority can compel a copyright owner to enter into a contract for a public policy reason, although the copyright owner might still have the freedom to negotiate the terms of the licence (unless it is a statutory licence). In a policy-based implied contractual licence on the other hand, the copyright owner enters into

\footnotetext{
${ }^{4}$ See Andrew Phang, 'Implied terms revisited', [1990] JBL 394, 410, where he refers to some of these criticisms.

${ }^{5}$ Gerard McMeel, The Construction of Contracts - Interpretation, Implication and Rectification (2nd edn, OUP 2011) paras [10.16]-[10.30].

${ }^{6}$ Phang, 'Implied Terms' (n 4) 410-11.

${ }^{7}$ See Chapter II, section 3.3.1 above.
} 
the contract voluntarily; but the court implies a licence within such contract for the consideration already given, in order to give effect to a public policy.

This distinction is relevant because the circumstances under which compulsory licences can be granted in relation to the subject matter covered by the Rome Convention (RC) are limited. Article 15(2), RC states that compulsory licences can be provided for only to the extent that they are compatible with the provisions of the RC. This means that the only circumstances where compulsory licences can be granted are in relation to broadcasting of performances under art $7(2)(2)$, publication of phonograms under art $12, \mathrm{RC}$ and communication to the public of certain broadcasts under art 13(d), RC. ${ }^{8}$ These limitations do not apply to policy-based implied contractual licences because they are distinguishable from compulsory licences. Thus, the openendedness of policy-based implied contractual licences is maintained.

I propose the approach adopted by the courts in contract law for implying a term by law as the framework for implying a policy-based contractual licence. I discuss this approach in section 1, and show how the terms implied are vindicated by statutory embodiment. Section 2 turns to the copyright context, to discuss firstly, the few cases where the courts have implied a policybased licence to repair within a contract, without applying to any specific methodology of implication. Although many such instances are now addressed in statues, there may still be instances requiring courts to imply a policy-based licence. In those cases, applying the contract principles of implying a term by law can provide the doctrinal support. Secondly, it discusses the statutory doctrine of exhaustion. One might have expected the doctrine of exhaustion to be an additional example of courts implying a policy-based licence to resell, into every contract of sale of a product incorporating copyright work. However, this is addressed by the statute (CDPA) making it stand on its own, eliminating the need for the courts to imply a licence. Section 3 provides conclusions, and connects the discussion to the upcoming Chapters.

\footnotetext{
${ }^{8}$ Sam Ricketson and Jane Ginsburg, International Copyright and Neighbouring Rights (Vol 2, OUP 2006) para 19.16.
} 


\section{Implication of Terms by Law}

In contract law, the source of a term implied-by-law can be common law or statute. The following paragraphs deal with both these scenarios.

\subsection{Terms Implied by Courts}

Courts have adopted a loose methodology for implying a term by law, with the objective of bringing consistency in its application. However, ironically, the courts themselves have been inconsistent in applying the methodology.

\subsubsection{Type of contracts}

In the words of Lord Cross in Irwin, while implying a term by law, the court is laying down a 'general rule' that in all contracts of 'a certain type' some provision is to be implied, unless the parties have expressly excluded it. ${ }^{9}$ The well-recognised categories of contracts include sale of goods, hire purchase, agency, employment, tenancy and the like. ${ }^{10}$ In Irwin, the category was a tenancy agreement between the council and its tenants in high-rise block of flats. When a term is implied, it is meant to apply to all contracts of that type. The logic is that the term implied addresses the standard incidents of a specific category of contracts, rather than giving effect to a bargain. ${ }^{11}$ This helps to bring consistency in the court's approach.

However, it is not always clear how the court goes about defining the type of contract into which the term will be implied. ${ }^{12}$ In Reid v Rush \& Tompkins Group Plc, ${ }^{13}$ an employee employed

\footnotetext{
${ }^{9} \operatorname{Irwin}(\mathrm{n} 3)$ 257-58.

10 Atiyah and Smith (n 2) 159.

11 ibid 160; see also Jack Beatson, Andrew Burrows and John Cartwright, Anson's Law of Contract (30th edn, OUP 2016) 155

12 Phang, 'Implied Terms' (n 4) 404-07; Elizabeth Peden, 'Policy concerns behind implication of terms in law' [2000] LQR 459, 461-2; Andrew Phang, 'Implied terms in English law - some recent developments' [1993] JBL 242, 247-8.

13 [1990] 1 WLR 212 (CA).
} 
overseas to drive a vehicle was injured in an accident during his employment. The court was unwilling to imply a term that all employers must insure employees, on the basis that it would be too onerous on the employers. ${ }^{14}$ In other words, defining the type of contract as all employment contracts was found to be too broad. However, the court could have defined a narrower type of contract within the larger category of employment contracts, which it did in Scally $v$ Southern Health and Social Services Board. ${ }^{15}$ Here, the employer had a pension scheme for its employees whose terms were complex, and the employees had to depend on the employer to explain its terms. The court implied into the employment contract that the employer had an obligation to explain the terms to the employees. However, this did not apply to all employment contracts, but only to those where the employees did not have an opportunity to negotiate the contract individually, and where the employment contract had terms of value to employees which they might not be aware of, unless their attention was drawn to them. ${ }^{16}$

Thus, classifying a contract is intended to bring consistency by implying the same term into all contracts of that type; but defining the class of contract itself is mired in inconsistency. While in principle it should be possible for courts to define in any manner, the type of contracts into which a term will be implied, ${ }^{17}$ there are also cases where courts have shown reluctance to recognise a new type of contract. ${ }^{18}$ And the reason for such reluctance is not always clear.

\subsubsection{Test of necessity or reasonableness?}

Some judges claim that the underlying principle for implying a term-by-law is 'necessity', and not 'reasonableness'. In Irwin, providing and maintaining elevators was found by the House of Lords

\footnotetext{
14 ibid 227-28.

15 [1992] 1 AC 294 (HL).

16 ibid 307.

${ }^{17}$ Hugh Collins, The Law of Contract (4th edn, Lexis Nexis 2003) 244.

18 Peden (n 12) 463-64.
} 
to be necessary in a multi-storeyed building with individual living quarters. However, commentators doubt whether under the circumstances of that case, providing these facilities was strictly necessary. Likewise, in Scally, it was not strictly necessary for the employer to inform the employees about the pension scheme. The employees could have come to know of it from other sources. Therefore, it is unclear how strictly courts construe necessity. Curiously, courts have also observed that rather than focussing on the elusive concept of necessity, it is better to recognise that the implied terms raise questions of reasonableness, fairness and balancing of completing policy considerations. ${ }^{19}$ Commentators point out that the courts seem to be advocating implying a term when it is 'reasonably necessary'.

Peden goes a step further and argues that the courts should be more honest about the reasons that drive their decisions, rather than hiding behind the vagueness of the test. She puts forward several policy considerations to which courts tacitly give effect. ${ }^{21}$ For example, in Irwin the court held that in a building with multiple occupants, it was implied in the terms of lease that the landlord owed a duty to take reasonable care to keep the common areas of the premises in reasonable repair and usability. ${ }^{22}$ This was because the landlord was better placed than the tenants to bear such responsibility. Therefore, this is a case of efficient allocation of resources, as it would have been expensive and time consuming for the tenants to organise themselves to maintain common areas. ${ }^{23}$ In Scally, it was recognised that the contract of employment was not individually negotiated, and therefore an employee could not be expected to be aware of it unless his attention was drawn to it. ${ }^{24}$ Thus, bringing about a balance in a standard form contract can also be one of

\footnotetext{
${ }^{19}$ Crossley v Faithful and Gould Holdings Lid, [2004] EWCA Civ 293 [36].

${ }^{20}$ Atiyah and Smith (n 2) 161; Phang 1 (n 4) 400-02.

${ }^{21}$ Peden (n 12) 467-75.

${ }^{22} \operatorname{Irwin}(\mathrm{n} 3) 254$.

${ }^{23}$ Collins (n 17) 245.

24 Scally (n 15) 307.
} 
the objectives that the courts pursue. ${ }^{25}$

When one analyses the courts' decision in the manner Peden suggests, in most cases the objectives that the courts intend to achieve by implying a term into a contract can be captured by the broader concept of reasonableness. Therefore, owning up to a standard of 'reasonable necessity' and being clear about the policy being pursued could bring greater clarity to the court's approach.

\subsection{Terms Implied from Statutes}

A term implied by the courts may eventually be codified into a statutory provision. Examples include Sale of Goods Act (SGA), ss 12 to 14, which deal with implied terms such as buyer's right to clear title, fitness for purpose, satisfactory quality, and so on. These terms have gone on to be codified also in other statutes like Supply of Goods (Implied Terms) Act, 1973, ss 8-11, Supply of Goods and Services Act, 1982, ss 2-5, 7-10 and 13-15. In addition, Unfair Contract Terms Act (UCTA), s 6, contains restrictions on the ability of contracting parties to exclude these terms. Further, Consumer Rights Act (CRA), ss 9-18, ss 34-41 and 49-53, provide that consumer contracts be treated as 'including' the terms on title, quality and fitness for purpose. The CRA no longer uses the word 'implied', as these terms are meant to be part of the contract.

With all these mandatory terms, scholars observe that the characterisation of these provisions as terms of contract, as opposed to rules of private law, is increasingly artificial. ${ }^{26}$ However, statutory embodiment of terms which the courts had originally been implied by law should be seen more as a vindication of the courts' decisions, than as a restriction on the general powers of the courts. The legislative provisions enumerated above bring certainty to litigants in relation to the terms specifically codified. But these provisions should not be read as a general

\footnotetext{
${ }^{25}$ Peden (n 12) 472-73.

${ }^{26}$ McMeel (n 5) para [10-30].
} 
prohibition on the courts' discretion to rise to newer occasions to imply terms by law as the circumstances demand.

\section{Policy-based Implied Contractual Licences in Copyright Context}

Despite its inadequacies, the method adopted by the courts for implying a term by law has its place in contract law. This section will demonstrate that this methodology can provide the doctrinal basis for implying a policy-based implied copyright licence. ${ }^{27}$ The two situations considered here are: firstly, a licence to repair implied by the courts, and secondly, the statutory doctrine of exhaustion.

\section{$2.1 \quad$ Licence to Repair}

A person who purchases a product incorporating copyright must be able to prolong its life by repairing it, as an incident of the ownership of the product. If in the process of repair, the owner of the product must reproduce the copyright work incorporated in the product, the copyright owner cannot interfere by asserting her exclusive right of reproduction. The purchaser must have a licence to reproduce the copyright work to repair the product, implied into the contract of purchase. ${ }^{28}$ Such implication is more appropriately attributable to the policy objective of noninterference with the enjoyment of the product purchased, than to the intention of the parties.

The issue of repair can arise with both tangible products (for example, machinery) and intangible products (for example downloadable software). Tangible products tend to be industrial goods (as opposed to say books or paintings), whose spare parts might incorporate copyright

\footnotetext{
27 'Policy-based implied licence' is used in preference for 'implied-by-law' for the reasons explained in Chapter II, section 3.3 above.

${ }^{28}$ As the law stands, it is unlikely that a seller has a general liability to provide repair services for the products she sells, under SGA, s 14. See Michael Bridge, The Sale of Goods (3 $3^{\text {rd }}$ edn, OUP 2014) para [7-118]. Even if there was a liability on the seller/manufacturer to provide repair services in rare circumstances, it is a separate issue from denying the manufacturer the ability to interfere with repair by asserting their copyright. See Saphena Computing Limited $v$ Alliance Collection Agencies Ltd [1995] FSR 616, 637.
} 
works (such as drawings) and hence, repair could interfere with the exclusive rights. With industrial goods, it is more common for patent rights to interfere, alone or in combination with copyright, while software is more likely to raise only copyright issues.

Unsurprisingly therefore, licence to repair originated in patent law, and moved over to copyright law subsequently. A patent grants the patentee of a product the exclusive right to make, use, exercise and vend the invention, among others. ${ }^{29}$ A strict interpretation of this language leads to an absurd conclusion that a person who purchases a patented product infringes the patent if she used the product. To avoid this absurdity, the courts historically applied the doctrine of implied licence. ${ }^{30}$

One of the earliest cases to raise this issue was Betts $v$ Willmott. ${ }^{31}$ At issue in this case was a patent for making metallic capsules for covering the corks and necks of bottles. ${ }^{32}$ The capsule had been patented in England and France, and manufactured in both these countries. Betts claimed that Willmott, a chemist, had been selling capsules in England similar to the patented capsule, in violation of the patent. Willmott claimed that he procured the capsules from suppliers in London, who may have been supplied by Betts' manufactory in France. Betts claimed that even if that was true, they could not be sold in England without his permission. ${ }^{33}$

The question was whether there was an unauthorised use of the patent. ${ }^{34}$ Lord Hatherley held that if Betts had not supplied the capsules at all, there would have been unauthorised use. He further held:

\footnotetext{
${ }^{29}$ Patents Act, 1977, s 60(1)(a).

${ }^{30}$ United Wire Ltd v Screen Repair Services (Scotland) Ltd [2001] FSR 24 [16].

31 (1871) LR 6 Ch App 239.

32 ibid 240.

33 ibid 240-41.

34 ibid 242.
} 
[W] here a person carries on the two manufactories himself, and himself disposes of the article abroad, ... he transfers with the goods necessarily the license to use them wherever the purchaser pleases. When a man has purchased an article he expects to have the control of it, and there must be some clear and explicit agreement to the contrary to justify the vendor in saying that he has not given the purchaser his license to sell the article, or to use it wherever he pleases as against himself... [H]e can use it against the person who himself is proprietor of the patent, and has the power of conferring a complete right on him by the sale of the article. $^{35}$

Lord Hatherley therefore found that there was no unauthorised use. The significance of Betts lies in its use of the language of licence - permitting the purchaser of a product to use the product in whatever way she pleases. The plain language of the judgment makes the scope of this licence broad and open to interpretation. For example, for products with limited life, 'use' could imply 'repair', on the basis that if one cannot repair, one cannot use. In the subsequent years, courts confirmed that there was such a licence to repair. ${ }^{36}$ In Sirdar Rubber Company Limited $v$ Wallington, Weston $\& \mathrm{Co}^{37}$ repair was held to be limited to prolonging the life of a product, but not to make a new one under the cover of repair. ${ }^{38}$

Against this backdrop, Solar Thomson Engineering Co Ltd v Barton ${ }^{39}$ considered what should happen if the product incorporated both a patented invention and a copyright work? If, as per Betts, the purchaser can do what he pleases with the product, does the purchaser acquire a licence also to reproduce the copyright work to effect repairs? In Solar, the plaintiff held a patent for certain pulleys and the copyright in the corresponding engineering drawings. The defendants were the providers of repair services and the manufacturers of replacement parts for machinery, made to an order placed by the customers of the plaintiff. The replacement parts were manufactured by way of working drawings, which were held to be substantially similar to the patentee's working

\footnotetext{
35 ibid 245 (Emphasis supplied).

${ }^{36}$ Dunlop Pneumatic Tyre Co Ltd v Neal (1899) 16 RPC 247.

${ }^{37}$ (1907) 24 RPC 539.

38 ibid 543.

39 [1977] RPC 537.
} 
drawings, and therefore, a reproduction. The plaintiff claimed infringement of both patent rights and copyright. ${ }^{40}$ The Court of Appeal held that such reproduction of copyright drawings was no more than repair of the patented machinery, permitted by an implied licence in favour of the owner of the patented machinery. To quote Buckley LJ: ${ }^{41}$

If I am right in the view I have expressed about the existence here of an implied licence under the patent to repair pulleys by replacing worn rubber rings, it must, I think, follow that purchasers of Polyrim pulleys are also impliedly licensed to infringe the plaintiffs' copyright in their drawings to the extent necessary to enable such repairs to be carried out. To hold otherwise would be to allow the copyright to stultify the implied licence under the patent. (...) [A]ny purchaser of a patented article might find himself deprived of his ostensible right to repair that article by the existence of a copyright of which he would probably be ignorant when he made the purchase.

The language of Buckley LJ asserts that copyright protection cannot make the implied licence under patent law illusory. If there are reasons to prevent the rights owner from asserting her patent rights, those reasons should similarly prevent the same rights owner from asserting her copyright. Although Buckley LJ mentioned business efficacy as the reason for implying the copyright licence, ${ }^{42}$ it is more appropriate to ascribe the implication to the policy objective of not interfering with the property rights of the purchasers of products incorporating patent rights and copyright works.

However, in United Wire Ltd v Screen Repair Services (Scotland) Ltd, Lord Hoffmann disapproved of the implied licence approach to repair under patent law in Solar. He preferred to ask the question whether the defendant 'made' the patented product, which is an exclusive right of the patentee, rather than asking whether the defendant had an implied licence to repair. $\mathrm{He}$ stated that repair shares a boundary with making but does not trespass upon its territory. ${ }^{43}$ This

\footnotetext{
40 ibid 560. The contract of sale of the machinery expressly reserved copyright in the drawings to the patentee. However, Buckley, LJ held that an express term is not inconsistent with implying a term. ibid.

41 ibid 560-61 (Emphasis supplied).

42 ibid 561.

43 [2001] FSR 24 [19]-[20].
} 
means that making a patented product has a higher threshold than repairing it, and so any person can undertake repair of a patented product without infringing the right to make it. Since this decision, the right to repair in patent law is a matter of interpretation of the patentee's exclusive right to make, rather than a matter of implied licence of exclusive right to use. ${ }^{44}$

Lord Hoffman expressed no views on copyright in United, as the facts did not warrant it. However, the same interpretation cannot be true of copyright, as the exclusive rights of copyright are different. The only way to legitimate reproduction for repair purposes is by a licence. ${ }^{45}$ Therefore, implied licence argument should continue in relation to copyright.

However, even in purely copyright cases like in software, implied licence to repair has not been adopted. In the Singapore Court of Appeal decision in Creative Technology Ltd v Aztech Systems Pte $L t d{ }^{46}$ Azetech reverse engineered a sound card made by Creative Technology, and in the process, copied Creative's software. Relying on Betts principle, Azetech claimed that such right to copy was a reasonable use, which emanates from Azetech's purchase of Creative's Sound Blaster card and the software that came with it, although Azetech was commercially producing sound cards in competition with Creative's sound cards. ${ }^{47}$ The Court observed that unlike a patented article, when a copyright article is sold, the economic interests in the copyright and moral rights still remain with the copyright owner. It was therefore, held that there was no place for Betts principle in Singapore copyright law. ${ }^{48}$ This decision is problematic. Implied licence is necessary because exclusive rights still remain with the copyright owner. If the copyright owner did not retain exclusive rights, nothing would stop the purchaser from repairing her product. The decision could

\footnotetext{
${ }^{44}$ Schütz, (UK) Ltd v Werit (UK) Ltd [2011] EWCA Civ 303 [62].

45 But see British Leyland Motor Co Ltd v Armstrong Patent Co Ltd [1986] 1 All ER 850 where the House of Lords applied the principle of non-derogation from grant to permit repair, rather than implied licence. See Chapter VII, section 2.4.3 below.

${ }^{46}$ [1997] 1 SLR 621.

47 ibid [1]-[7].

48 ibid [83]-[84].
} 
have been better supported by pointing to the lack of a genuine repair presented by the case, rather than denying a place for Betts principle.

It is not clear why there is such hesitation in accepting Betts in copyright law. Indeed, Betts is more relevant to copyright law than patent law, given the reasons in United for discarding implied licence approach for patent cases. Solar, which is an essential connection of Betts principle to copyright law, was not mentioned in Creative. The hesitation may be because Betts and Solar appear to be isolated cases, lacking in doctrinal support. The following paragraphs try to resolve this hesitation by applying the methodology of implying a term by law into a contract, to cases where Betts and Solar might apply, to bring doctrinal clarity to the implication.

\subsubsection{Type of contract}

The right to repair can arise in relation to both industrial goods and software. Before defining the type of contract into which a licence to repair could be implied, one must locate the contract in a typical dispute concerning industrial goods, and the beneficiary of the licence. The dispute is normally not with the purchaser of the product, but with the person who carried out the repair, like in Solar. But the licence is implied into the contract of purchase. This licence is in turn sublicensed to the person carrying out the repair, upon being commissioned to do so by the purchaser. However, it is more common in the market economy for the person carrying out the repairs to produce spare parts in advance of receiving orders from the purchaser, like in United, building a stock of spare parts to service the demand efficiently. This prevents a devolution of the implied licence from the purchaser, as the spare parts which need reproduction of copyright works are manufactured not in response to, but in advance of receiving an order to repair from the purchaser. This was perhaps an unacknowledged reason why the implied licence approach to repair was rejected in United. Therefore, contracts such as that at issue in United are excluded from the application of Betts or Solar like licence.

This leaves us with a small group of contracts relating to industrial goods to which Betts or Solar might apply. This issue is unlikely to arise when the product is software, since repairing a 
software is unlikely to require spare parts being manufactured in advanced. However, repairing a software could involve reproducing the software, including to decompile it or to remove errors.

How do we define the type of these contracts, so that a licence permitting the reproduction of the copyright work to enable repair may be implied into all contracts of this type? Defining these contracts as sale of goods under SGA, s. 2, is an option. However, the SGA only applies to tangible goods. ${ }^{49}$ Products like downloadable software which do not exist in a physical form may not be covered in this type of contracts. If the purchaser is a consumer within the definition of the CRA, s 2(3), ${ }^{50}$ then it can be classified as a consumer contract. Although the CRA specifically applies to digital content, ${ }^{51}$ cases like Creative cannot be covered, since the purchaser of the product was not a consumer, but was a business entity. A third category may be created for contracts such as that at issue in Creative.

Depending on the context, it is possible to define the type of contract. As argued above, in principle, courts should be able to define a contract as narrowly as the circumstances require.

\subsubsection{Reasonable necessity of repair}

Market economy demands that in a vast majority of industries spare parts be produced in advance, to meet the demand efficiently. This leaves a small class of sophisticated and perhaps expensive machinery, where the purchasers may have spare parts made to order. In these cases, the manufacturer is likely to exercise control over the spare parts market, and quite likely, the purchasers themselves might prefer spare parts from the original manufacturer, given the sophisticated nature of the machinery. However, in principle, if a purchaser does want a third party repair service to be able to supply spare parts upon order, it should still be possible for the

\footnotetext{
${ }^{49}$ SGA, s 61(1) defines goods as all personal chattels other than things in action and money.

50 An individual acting for purposes wholly or mainly outside his trade, business, craft or profession.

${ }^{51}$ CRA, s 2(9) defines digital content as data which are produced and supplied in digital form, which is broad enough to include software.
} 
court to imply a licence to reproduce spare parts in furtherance of repair, based on Solar. The policy consideration of giving effect to the property rights of the purchasers of industrial products should meet the required standard of reasonable necessity.

This leaves us with software contracts which might also be assessed under Solar, since the purchaser might need to make a copy of the software to debug or decompile it or to study it. Some of these instances are now addressed by statutes, as detailed below. In all other cases, in principle, it should still be possible to argue that such repair is reasonably necessary.

\subsubsection{Statutory provisions embodying repair}

Licence to repair is another classic example of common law acting as a testing ground before the eventual codification in the UK. Section 51, CDPA denies copyright protection for the design drawings. Instead, a separate regime of unregistered design protection has been introduced, under Part III, CDPA, which is for a shorter duration than copyright, and with much less extensive rights than copyright. ${ }^{52}$ The exceptions to design rights are embodied in s 213(3)(b)(i) for features of an article that enable one article to connect with another (must-fit exception), or s 213(3)(b)(ii) for features dependent upon the appearance of another article forming an integral part (mustmatch exception). These amendments were made to address the spare parts market, such that spare parts shaped in a way that makes them fit with a product would be exempted by the must fit exception..$^{53}$

Regarding software, s 50A(2), $\mathrm{CDPA}^{54}$ permits a person having a right to use the software under a license or otherwise ('lawful user'), to make back-up copies under s 50A, decompile under s $50 \mathrm{~B}$, and observe, study or test the functioning of the software to determine the ideas and

\footnotetext{
${ }^{52}$ CDPA, s 226-227.

53 Ultraframe UK Ltd v Clayton [2002] EWHC 1964 (Ch) [73]; quoted with approval in Dyson Ltd v Qualtex (UK) Ltd, [2005] IP \& T 656 [18]-[19], [33], although here Mann J argues that there is nothing in the provisions of Part III, CDPA to restrict them to spare parts alone.

${ }^{54}$ Implementing art 5, Software Directive (2009/24/EC).
} 
principles underlying it under s 50BA(1). These three provisions cannot be overridden by a contrary contractual provision. However, under s 50C, a lawful user can copy or adapt the software as necessary for lawful use or to correct errors (repair), subject to any contractual term to the contrary. These amendments came into force in 2003 , before which the common law warranty of fitness for purpose was extended to software to permit correcting errors. ${ }^{55}$

Additionally, a consumer has protection under s 43(2), CRA, whereby she can have her digital content repaired if the digital content is not of satisfactory quality under s 34 , CRA. The trader must carry out the repair without the consumer having to bear the cost for labour or material, or any inconvenience. This discourages consumers from approaching third parties who will charge them for repair services. Therefore, in practice, a third party repair service provider having to be impliedly licenced to reproduce the digital content to repair it, might be rare.

Similar to the statutory provisions discussed in section 1.2 above, the enactment of these provisions does not take away from the courts' power to imply a policy-based licence in situations not covered by these provisions. As demonstrated in sections 2.1.1 and 2.1.2 above, there is sufficient doctrinal support in contract principles of implying a term by law, for the courts to rely on for this purpose.

\subsection{Doctrine of Exhaustion}

The justification for the protection of any intellectual property is that it gives the owner a recompense for the time, effort and money in the creation of the invention or the work. The creation or invention may result in the production of a product, which may then become a subject of commerce. The compensation which the intellectual property owner can extract on the first sale of such product is regarded a just recompense so long as the sale happens with her consent. Thereafter, in principle, the product can be freely sold, and the IP owner cannot assert her

\footnotetext{
55 Saphena (n 28) 439-40.
} 
exclusive rights to prevent such resale. In the terminology of continental jurisdictions, the copyright owner has 'exhausted' her rights by such authorised first sale. ${ }^{56}$

In principle, exhaustion sounds similar to the licence in Betts, especially since the core issue in Betts was also resale of products purchased. However, Betts principle was never extended to copyright cases until Solar, which was in any event only in repair context as discussed above, and not in resale context. This was because until the enactment of s 18, CDPA, a copyright owner did not have the right to prevent someone reselling her work, or more generally, a right to issue copies to the public. She only had the right to publish, ${ }^{57}$ which meant making public a work which had been previously unpublished. ${ }^{58}$ Once the work was published, this right did not interfere with the ability of the purchaser of the copyright work to resell, negating the need to imply any licence. Thus, purchasers of products incorporating copyright works were free to resell those works.

With the introduction of the exclusive right to issue copies to the public, if each time a purchaser wanted to sell her copyright goods, she had to seek the permission of the copyright owner, it would increase transaction costs. The doctrine of exhaustion had to be introduced to achieve the larger objective of facilitating uninterrupted trade in products incorporating copyright works, by ensuring non-interference from the copyright owner in the market, after she has disposed of her work for the first time (called the aftermarket). The importance of exhaustion is magnified with international trade gaining momentum over the past century.

Section 18, CDPA embodies the doctrine of exhaustion. It conveys that the exclusive right to issue copies to the public is only infringed if a person puts into circulation copies of a work in the EEA for the first time, without the consent of the copyright owner. A person is,

\footnotetext{
${ }^{56}$ Gillian Davies, Nicholas Caddick and Gwilym Harbottle, Copinger and Skone Janes on Copyright (17th edn, Sweet \& Maxwell 2016) paras [24-18].

${ }^{57}$ Copyright Act, 1956, s 2(5)(b) for literary works and s 3(5)(b) for artistic works.

${ }^{58}$ Infabrics Ltd v Jaytex Ltd [1981] 1 All ER 1057, 1067; see also John Phillips and Lionel Bently, 'Copyright issues: the mysteries of section 18' [1999] EIPR 133.
} 
therefore, free to resell a copy of the work already in circulation within the EEA with the consent of the copyright owner, not because the copyright owner grants her an implied licence to resell, but because the copyright owner's exclusive right itself does not extend to such act.

To explain further, in Betts, implied licence in favour of the purchaser of a patented product was necessary because the exclusive rights of a patentee included the right to 'use' the patented product. Since the statute did not further qualify the word 'use', courts had to step in to imply a licence to permit the legitimate use of a patented product by its purchaser. Similarly, if within the exclusive rights of copyright, there was an unqualified right to issue copies to the public, courts would have to step in to imply a licence to reduce transaction costs and facilitate trade. However, the right to issue copies to the public is not an unqualified right - but is confined to copies not already put into circulation within the EEA, by or with the consent of the copyright owner. This qualification liberates subsequent copies to be freely circulated within the EEA, if the first issue within the EEA had been with the consent of the copyright owner. Therefore, this statutory qualification meets the policy objectives of saving transaction costs and facilitating trade, eliminating the need for the courts to imply a licence on that basis.

In Hohfeldian terms, the copyright owner has 'no right' to stop a person reselling her work once she has issued copies within the EEA. Likewise, a person enjoys a corresponding privilege to resell the product in the EEA by virtue of s 18, and owes no duty the copyright owner not to do so. The jural relation that s 18 creates is already that of privilege-no right between the user and copyright owner, and there is no need for any operative facts to change that. Accordingly, there is no need for implying a licence. Therefore, exhaustion, defined in this sense, ${ }^{59}$ is not covered in this thesis.

\footnotetext{
${ }^{59}$ North American scholars define exhaustion more broadly based on the provisions of the legislations and the case law in those respective jurisdictions. See for example Ariel Katz, 'Digital exhaustion: North American observations', in John A Rothchild (ed), Research Handbook on Electronic Commerce Law (Edward Elgar, 2016) 137-38; Aaron Perzanowski and Jason Schultz, Digital Exhaustion, [2011] 58 UCLA L Rev 889, 908.
} 


\section{Conclusions and Connections}

This Chapter discussed two situations where the issue of the implication of a policy-based licence into a contract might arise. Firstly, a licence to repair, where this Chapter showed that the courts do not necessarily acknowledge the method they adopt for such implication. It argued that although many instances of licence to repair are codified now, for those instances not addressed by statutes, courts should not hesitate to imply a policy-based licence into a contract. And for this purpose, the contract principles of implying a term by law discussed in section 1 above can provide the doctrinal support. Secondly, this Chapter dealt with the statutory doctrine of exhaustion, and demonstrated that it can be explained independently of implied licence.

The discussion on the licence to repair raises a question - what happens if a member of the public wishes to provide spare parts in advance of receiving instructions from her customers to repair? As stated above, she cannot rely on a sub-licence from the purchaser of the product incorporating copyright work. If the production of spare parts by such third parties involves reproducing copyright work incorporated in the product, can the third parties still receive a bare licence based on the public policy of facilitating the repair of the product in the most economical and efficient manner? This is discussed in Chapter VII below.

Many of the policy-based implied licences now being addressed in statutes does not render the very methodology of such implication obsolete. For content placed on the internet, if the terms of use amount to a contract, the methodology of implying a term by law could still be helpful, as discussed in Chapter VIII below. 


\section{Policy-based Implied Bare Licences}

Chapter VI above considered situations where a licence is implied for policy reasons into a contract. We saw that the existence of a contract reveals to some extent, voluntariness on part of the copyright owner. Judges regard themselves justified in implying a licence within such a contract, even if the licence does not strictly emanate from the consent of the copyright owner, but is attributable to a public policy. Even if no contract exists, i.e., no voluntariness on part of the copyright owner at all, courts still have the power to imply a bare licence to give effect to a public policy.

As we move from Chapter III towards this Chapter, one may notice the changing role of consent. Consent drove the implication in Chapters III and IV. In Chapter V, although the copyright owner does not individually consent, the community which represents her consents on her behalf. Consent exists to a limited extent in Chapter VI in the copyright owner entering into the contract voluntarily, and not in relation to the specific licence that is implied ex post, within such contract. These Chapters demonstrate that there is both doctrinal and theoretical support for the implication of a copyright licence even with the dwindling role of consent as a basis for such implication. This Chapter represents the end of this spectrum where consent of the copyright owner has no role to play at all.

Chapter II above identified s 171(3), CDPA, as saving the common law rule preventing or restricting copyright enforcement in public interest, if it existed, on the strength of which the courts could imply a policy-based bare licence. ${ }^{1}$ Therefore, such common law rule must be established first, before it can form the basis for implication. This is dealt with under section 1. Section 1 goes on to argue that the common law origin of this rule makes the policy-based

\footnotetext{
${ }^{1}$ See Chapter II, section 3.3.2.2.
} 
implied licences distinguishable from an L\&E, and thus not be subject to UK's international treaty obligations or obligations under the Infosoc Directive, despite opinions to the contrary by judges and scholars.

Given the importance of the three-step test as a methodological guideline in this Chapter, section 2 discuses briefly, the background of the test and the flexibilities inherent in its interpretation, emphasising the role of the courts in applying the test.

Section 3 reviews the actual cases where the courts have resorted to public interest to restrict or deny copyright enforcement, to show how these cases can be understood as policybased implied bare licences. It further examines whether the courts have given effect to public interest generally in compliance with the three-step test.

As noted in Chapter II, even if the implication of a policy-based bare licence does not comply with the three-step test, it may still be assessed for compliance with the FR regime. Section 4 examines how the FR regime can guide the courts' interpretation of public interest.

Section 5 summarises the conclusions, and connects it to the last Chapter.

\section{Section 171(3), CDPA and the Common Law Rule}

Section 171(3), CDPA states that Nothing in this Part affects any rule of law preventing or restricting the enforcement of copyright, on grounds of public interest or otherwise.' As noted in Chapter II, s 171(3) only saves the common law rule empowering the courts to prevent or restrict copyright enforcement, if such rule existed before the enactment of the CDPA. ${ }^{2}$ This section establishes based on the legislative history of s 171(3) that such a rule did exist. It goes

\footnotetext{
${ }^{2}$ Chapter II, section 3.3.2.2 above.
} 
on to examine the nature of such rule and the manner in which it interacts with the UK's international treaty obligations and the Infosoc Directive.

\subsection{Historical Context of Section 171(3) and Courts' Power}

Before s 171(3) was enacted, the courts had held that public interest defence is different from an L\&E, and that it is a general principle of common law not limited to copyright. ${ }^{3}$ After its enactment, Aldous LJ noted that the L\&Es enumerated in the CDPA's Chapter III, Part I embodied the extent of public interest that can override copyright. And since s 171(3) exists outside this chapter, the power must arise from the inherent jurisdiction of the courts to refuse to let its process be used under certain circumstances. ${ }^{4}$ This decision should be sufficient to argue that s 171(3) does not qualify as an L\&E, but is an expression of a more general principle. ${ }^{5}$ However, commentators question the need for a statutory provision such as $\mathrm{s}$ 171(3), if indeed the source of power was already inherent in the courts. ${ }^{6}$

The legislative history of the CDPA reveals that when the provision was first contemplated, similar questions had been raised. Lord Morton wanted to introduce a provision simply stating that 'Copyright is not infringed by anything done in public interest', before the fair dealing provision. ${ }^{7} \mathrm{He}$ acknowledged that the courts already exercised a power to restrict copyright in public interest under certain circumstances, but added that the purpose of this provision was to confirm the power in the statute, rather than leave it for common law. In the

\footnotetext{
${ }^{3}$ Beloff v Pressdram [1973] FSR 33, 56

${ }^{4}$ Hyde Park Residence Ltd v Yelland [2000] EWCA Civ 37 [43]-[44].

${ }^{5}$ Jonathan Griffiths, 'Copyright law after Ashdown - time to deal fairly with the public' [2002] IPQ 240, 264.

${ }^{6}$ Robert Burrell, 'Defending the public interest' [2000] EIPR 394, 403; Robert Burrell and Alison Coleman, Copyright Exceptions The Digital Impact (CUP 2005) 81; Alexandra Sims, 'The public interest defence in copyright law: myth or reality?' [2006] EIPR 335, 338-9.

${ }^{7}$ HL Deb 08 December 1987, vol 491, cols 75-76.
} 
debate that ensued, the peers did not question the very existence of the public interest defence, but only the broad and general wording of the proposed provision, and the need for a statutory recognition of a public interest defence, when the courts are perfectly capable of carving it out themselves. ${ }^{8}$

In the next reading, Lord Morton placed it in the chapter that dealt with restating and amending copyright law, as he was of the view that public interest must find a mention in the bill, regardless of whether it is called an exception or a defence. Lord Lloyd supported it on the basis that other forms of intellectual property, such as trademarks, do provide a public interest defence. ${ }^{9}$ In the discussion that ensued, the peers were still not convinced that a public interest defence needed to be restated, although Lord Morton insisted that if not restated, it might be understood as the power having been taken away. ${ }^{10}$

In the subsequent readings, the government proposed the provision in the form that was eventually enacted. There was a debate as to whether public interest should itself be defined. A provision enumerating the instances of public interest as the disclosure of 'a matter of grave public concern or the existence of crime, fraud, abuse of authority, neglect in the performance of official duty or other misconduct', had been proposed. ${ }^{11}$ However, such definition of public interest was rejected, ${ }^{12}$ on the basis that any statutory provision embodying public interest should only continue the effect of the case law 'without attempting to codify it,

\footnotetext{
8 ibid cols $76-78$.

${ }^{9}$ HL Deb 23 February 1988, vol 493, cols 1162-63.

10 ibid col 1164.

${ }^{11}$ HL Deb 29 March 1988, vol 495, cols 630-31.

12 ibid cols 633-35.
} 
thus leaving the law on this matter where it has always been, in the hands of the courts'. ${ }^{13}$ This led to the final adoption of s 171(3) in its current form.

Thus, regardless of whether the power originates from the courts' inherent jurisdiction, the courts did have the power to restrict or prevent copyright enforcement in public interest, which they continue to have under s 171(3). ${ }^{14}$ It is important to note here that s 171(3) only confirms a pre-existing common law rule, and does not itself lay down a new statutory rule restricting or preventing copyright enforcement. The common law origin of the rule is crucial in distinguishing it from an L\&E. However, commentators and judges regard s 171(3) itself as a statutory rule amounting to an L\&E, and take issue with the open-endedness of the concept of 'public interest'. This makes them believe that s 171(3) does not comply with the UK's international obligations, which we consider in the next two sections below.

\subsection{Common Law Rule and the UK's International Obligations}

Aldous LJ claimed in Yelland that just as art 10, BC supports s 30, CDPA, there is no general public interest defence under the BC that supports s 171(3). On this basis, he concluded that s 171(3) goes against the UK's international treaty obligations. ${ }^{15}$ Although Aldous LJ had distinguished the common law origin of the powers under s 171(3), with this statement he appears to be stating that s $171(3)$ is similar to s 30, i.e., an L\&E. As argued in Chapter II above, a policy-based bare licence implied on the strength of s 171(3) is not an L\&E. ${ }^{16}$ As such, the provisions of the BC addressed only to L\&Es do not apply to policy-based implied bare licences. However, even if one concedes that s 171(3) is an L\&E, the BC does not

\footnotetext{
13 ibid col 632.

${ }^{14}$ Burrell (n 6) 399-404.

15 [2000] EWCA Civ 37 [55]

${ }^{16}$ See Chapter II, section 3.3.1 above.
} 
prescribe an exhaustive list of L\&Es. Indeed, the BC only contains enabling provisions addressing what a legislature can do with the L\&Es, and does not take away the powers of the courts derived from common law.

One of the provisions that could have a bearing on public interest is art 17, BC, which empowers a Union member's government (including all competent authorities) to control or prohibit the circulation of a work as it finds necessary. The underlying principle is ordre publique, a notion rooted in a state's ability to control based on morality and other socio-cultural values. ${ }^{17}$ Burrell rightly points out that a government can delegate the protection of morality and values to courts, and that the common law rule under s $171(3)$ would comply with this provision. ${ }^{18}$ Thus, art $17, \mathrm{BC}$ not only addresses an L\&E, but also enables a court to control or prohibit the circulation of a work under the common law rule under s 171(3). However, public interest embodied in the common law rule is a much broader concept than ordre publique, as evidenced also by case law discussed under section 3 below.

Article 9(2) which embodies the three-step test is another provision put forward when the validity of an L\&E is to be assessed. When the test was first introduced, the objective was to unify the existing L\&Es and guide the future ones. ${ }^{19}$ Article 9(2) opens with the words 'It shall be a matter for legislation in the countries of the Union (...)'. Thus, the provision is clearly addressed to the legislature of the Union members, and the tenor of this provision is enabling. Union member legislatures enjoy a level of freedom in adopting the L\&Es of their

\footnotetext{
${ }^{17}$ Sam Ricketson and Jane Ginsburg, International Copyright and Neighbouring Rights (Vol 1, OUP 2006) para [13.88].

${ }^{18}$ Burrell (n 6) 396.

${ }^{19}$ Martin Senftleben, Copyright, Limitations and the Three-Step Test (Kluwer Law 2004) 43-82; Ricketson and Ginsburg (n 17) paras [13.03]-[13.09].
} 
choice, so long as the three requirements were satisfied..$^{20}$ Art 9(2) therefore, does not address what a court within a Union member can do, nor does it take away the powers that the courts have always enjoyed. Over the years, the test has been adopted by many subsequent international treaties in relation to a wider array of rights, all of which regard the test as enabling the legislature of the respective contracting parties to design their L\&Es. ${ }^{21}$ Being not an L\&E, a policy-based implied bare licence, is therefore unaffected by the three-step test.

In any event, Burrell argues that the s 171(3) is in compliance with art 9(2), BC. ${ }^{22}$ Not all commentators agree that an open-ended provision allowing the courts to define 'certain special cases' complies with the art 9(2). ${ }^{23}$ However, fair use under s 107, US Copyright Act 1976 is an open-ended exception. The accession of the US to the BC (through art 9(1), TRIPS) was premised on the acceptability of fair use under the $\mathrm{BC} .{ }^{24}$ The fair use provision remains unchallenged at the international level all these years. ${ }^{25}$ Further, the fair dealing provision is also open-ended to the limited extent of allowing the courts to decide on a case by case basis what is 'fair'. Fair dealing existed under s 6, Copyright Act 1956, which did not prevent the UK's accession to the Stockholm Act of $1967 .{ }^{26}$ This provision too, now under s 30, CDPA,

\footnotetext{
${ }^{20}$ Mary Vitoria, et al, Laddie, Prescott and Vitoria The Modern Law of Copyright and Designs (4th edn, vol 1, Lexis Nexis 2011) para [21.4].

${ }^{21}$ TRIPS, art 13; WTC, art 10; WPPT, art 16.

22 Burrell (n 6) 396.

${ }^{23}$ Sam Ricketson, 'The three-step test, deemed quantities, libraries and closed exceptions' (Centre for Copyright Studies 2002) 31, 147-54.

${ }^{24}$ Pamela Samuelson, 'Challenges for the WIPO and the TRIPS Council in Regulating Intellectual Property Rights in the Information Age’ [1999] EIPR 578, 582-83.

${ }^{25}$ Senfleben, 'Copyright, Limitations' (n 19) 162-8 as to why fair use is compliant with the three-step test.

26 Acceded to on 26 February 1969, per <http://www.wipo.int/treaties/en/remarks.jsp?cnty_id=1043C> accessed 19 November 2016
} 
has never been challenged for violating art 9(2). Therefore, the open-endedness of an L\&E by itself does not violate the three-step test.

To the extent that the three-step test is not implemented expressly in the UK national legislation, UK courts are not obliged to recognise the direct application of art 9(2), BC, or other provisions embodying the test in other treaties. However, this does not mean that the court should never look at treaty provisions to interpret the law. ${ }^{27}$ The test could be useful for the courts as a methodological guideline in assessing the contours of public interest.

Although the international treaties discussed above do not require an exhaustive list of L\&Es, art 15(2), RC does place a restriction on compulsory licences relating to the subject matter covered by the RC to the situations covered under arts 7, 12 and 13, RC. However, for the reasons described in Chapter II above, policy-based implied bare licences do not amount to compulsory licences, and therefore, are not limited in their scope or operation by art 15(2), RC. It may be reiterated that s 171(3) only confirms a pre-existing common law power, and does not grant new statutory powers to courts. The open-endedness of such common law rule is in stark contrast to the statutorily limited policy objectives that can be achieved by a compulsory licence.

\subsection{Common Law Rule and Infosoc Directive}

The Infosoc Directive, which was meant to implement the WIPO Internet Treaties, has a restrictive regime governing L\&Es. As discussed above, the three-step test under the WIPO Internet Treaties acted as a guideline to the legislature of the EU member states while adopting their own L\&Es. However, the Directive not only lists the specific L\&Es in arts 5(1)-(4), but also makes this list exhaustive under recital 32. The Directive further requires the member

\footnotetext{
${ }^{27}$ J H Rayner (Mincing Lane) Ltd v Department of Trade and Industry [1990] 2 AC 418, 499-501.
} 
states to apply the three-step test in relation to all L\&Es from arts 5(1)-(4).

Since policy-based implied licences are not L\&Es, this section demonstrates that these provisions of the Infosoc Directive should have no impact, either through implied repeal or by indirect effect. However, since commentators regard s 171(3) to be an L\&E, this section first considers briefly the impact of the Directive on L\&Es in general and s 171(3) in particular.

Article 5(5), Infosoc Directive is problematic because, firstly, at the international level the EU was already under an obligation to follow the test under WCT while drafting the specific L\&Es. Having enumerated the specific L\&Es, the EU had complied with these obligations. Setting forth the test again in art 5(5) was not necessary. ${ }^{28}$ Secondly, at the national level while transposing arts 5(1)-(4), the legislature of the member states had already identified with specificity the circumstances where L\&Es apply. There should have been no further obligation on the member states to make the specific circumstance even more specific. ${ }^{29}$

Even if one were to accept the need for art 5(5) in the Directive, the bigger problem is the exhaustive list of L\&Es that the EU has decided to adopt. ${ }^{30}$ One may cite harmonisation and the resulting certainty of the law as the reason behind the closed list. Even if this was the objective, the EU has tolerated the lack of harmonisation in allowing member states to choose the exceptions to implement under arts 5(2)-(4), rather than making it mandatory to adopt all

\footnotetext{
${ }^{28}$ Guido Westkamp, The 'Three-step Test' and Copyright Limitations in Europe' (2008-2009) 56 J Copyright Soc'y USA 1, 24.

29 ibid 26; Christophe Geiger, Daniel Gervais and Martin Senftleben, 'The Three-Step Test Revisited: How to Use the Test's Flexibility in National Copyright Law' (2013) PIJIP Research Paper no. 2013-04, 36; Martin Senftleben, 'The International Three-Step Test A Model Provision for EC Fair Use Legislation' (2010) 1 JIPITEC 67, paras [11]-[13].

${ }^{30}$ Many commentators have recognised this problem. Jonathan Griffiths, 'Unsticking the centre-piece - the liberation of European copyright law?' 1 (2010) JIPITEC 87; Eleanora Rosati, 'Copyright in the EU: in search of (in)flexibilities' [2014] 9 JIPLP 585; Dirk Voorhoof, 'Freedom of expression and the right to information: Implications for copyright' in Christophe Geiger (ed), Research Handbook on Human Rights and Intellectual Property (Edward Elgar 2015) 351.
} 
exceptions. ${ }^{31}$ A list of specific exceptions does enhance certainty of the law. However, an additional open-ended exception based on the three-step test could have achieved both the objectives of certainty and flexibility. ${ }^{32}$ Disengaging the three-step test from the exhaustive list of exceptions could have met the need for flexibility in the current technological climate.

Commentators who regard s 171(3) as an L\&E require s 171(3) to be interpreted compatibly with the Infosoc Directive, by curtailing the open-endedness of public interest. Some commentators argue that the only extent to which s 171(3) survives is (i) where the CDPA has not yet transposed an exception from the Directive; (ii) to enforce freedom of expression; and (iii) under art 5(3)(o), Infosoc Directive, where a member state may provide for analogue use in certain cases of minor importance where the L\&Es to this effect already exist. ${ }^{33}$ Even if one were to agree with (i) and (ii) above, s 171(3) enables the courts not only to restrict, but also to prevent the enforcement of the entire copyright interest, which cannot be regarded as 'permitting use of minor importance' under art 5(3)(o).

Burrell and Coleman argue that s 171(3) may be read into art 5(3)(e) which provides for an exception to protect public security and to ensure performance of official duties. However, they acknowledge that public security is a slippery concept, stating that freedom of expression under the ECHR may be relied on in addition. They also cite art 9, Infosoc Directive which preserves national laws on confidentiality. They further argue that s 171(3) may act as the equivalent of the provisions that prohibit abuse of rights in other EU

\footnotetext{
31 William Cornish, David Llewelyn and Tanya Aplin, Intellectual Property (8th edn, Sweet \& Maxwell 2013) para [12.37].

32 Senftleben, 'EC Fair Use' (n 29) paras [54]-[57].

33 Vitoria (n 20) para [21.22]; Gillian Davies, Nicholas Caddick and Gwilym Harbottle, Copinger and Skone Janes on Copyright (17th edn, Sweet \& Maxwell 2016) [21-108]; Lionel Bently and Brad Sherman, Intellectual Property Law (4 ${ }^{\text {th }}$ edn, OUP 2014) 248.
} 
jurisdictions. ${ }^{34}$ Even if this argument was accepted, neither public security, nor confidentiality captures the full essence of public interest, given that public interest had served as the underlying reason for an exception permitting the manufacture of spare parts, as will be discussed below. ${ }^{35}$ Abuse of process might capture many instances of public interest cases, but public interest can still be a broader concept than this. ${ }^{36}$

Some commentators argue that the addressees of art 5(5) are not only national legislatures, but also national courts. ${ }^{37}$ Even if this argument is accepted, it only means that the courts must interpret the L\&Es in arts 5(1)-(4) transposed into their national law, in a three-step test compliant manner. ${ }^{38}$ It does not affect the other powers of the courts. Article 5(5) does not place a general obligation on the courts to apply the three-step test also in cases not addressed by arts 5(1)-(4).

Being a directive (as opposed to a regulation), Infosoc Directive requires national legislation for it to be applicable within the UK. ${ }^{39}$ While implementing the Infosoc Directive, the Copyright and Related Rights Regulations $2003^{40}$ could have enacted a provision amending s 171(3) to prevent courts from going beyond the enumerated L\&Es. However, the UK did not, because it was not obligated under the Infosoc Directive to do so. Recital 32, Infosoc

\footnotetext{
${ }^{34}$ Burrell and Coleman (n 6) 107-8.

${ }^{35}$ Lord Beaverbrook specifically cited British Leyland v Armstrong [1986] 1 All ER 850, in opposing the definition of public interest only to disclosure in certain cases. HL Deb 29 March 1988 vol 495, cols 632.

${ }^{36}$ See Chapter VIII, section 3 below for such instances.

${ }^{37}$ Christophe Geiger, 'From Berne to National Law, via the Copyright Directive: The Dangerous Mutations of the Three-Step Test' [2007] EIPR 486, 488-90. See also Vitoria (n 20) para [21.15].

${ }^{38}$ Richard Arnold and Eleanora Rosati, ‘Are national courts the addressees of the InfoSoc three-step test?’ [2015] 10 JIPLP 741, 743-44, 747-49.

39 TEU, art 288.

40 SI 2003/2498.
} 
Directive simply declares that the list of L\&Es in the Directive is exhaustive, directing the national legislatures to only legislate the L\&Es within that list. This provision, and indeed the Directive as a whole, do not obligate the national legislatures to also affect the powers of the national courts. Thus, in the absence of any conflict between the pre-existing provision (s 171(3)), and the law implementing a directive (the Regulations), there is no implied repeal. ${ }^{41}$

One may argue that the Infosoc Directive might still have an indirect effect on the UK courts because of the decision in Case 106/89 Marleasing SAv La Comercial International de Alimentacion $S A .^{42}$ The CJEU held in this case that a national court must interpret a national law as far as possible, in the light of the wording and the purpose of the directive, in order to achieve the result pursued by the directive. ${ }^{43}$ However, this principle applies where a directive is not yet implemented in the national law, in holding that whilst a directive has no direct effect on national law, it will have an indirect effect. As argued above, there is nothing in the Infosoc Directive that obligates the UK to curtail the common law powers of the courts. Where there was nothing in the Directive to be implemented in the national law, it is difficult to argue that the Directive still has an indirect effect on the national courts.

Even if s 171(3) is to be regarded an L\&E, Marleasing only requires harmonious construction of s 171(3) with the objectives of the Directive, and not a repeal of s 171(3). If s 171(3) is to be regarded a pre-existing L\&E (as it pre-dates the Directive), recital 31, Infosoc Directive, provides that the existing L\&Es should be 'reassessed in the new electronic environment.' This statement appears in the context of the need to strike a fair balance between the interests of the copyright owners and users, and goes on to say that any differences

\footnotetext{
${ }^{41}$ A W Bradley, et al, Constitutional \& Administrative Law (16 ${ }^{\text {th }}$ edn, Pearson 2015) 56.

42 [1990] ECR I-4135.

43 ibid para [8].
} 
in the existing L\&Es of the member states can have a negative effect on the internal market. Thus, it requires the existing L\&Es to be applied more harmoniously, with a view to achieving the smooth functioning of the internal market. Recital 32 declares the list of L\&Es to be a closed list, whereas recital 3 declares public interest as one of the fundamental principles of EU copyright law. In order to harmoniously construe s 171(3) with these provisions and to reduce any possible negative effects on the internal market, courts may apply the three-step test under art 5(5), in arriving at their decision. If the UK renegotiates to stay in the single market after Brexit, in a future case, if no other L\&E applies, under rare and exceptional circumstances, a court may still be able to exercise its powers under s 171(3). Thus, the scope of s 171(3) may be reduced if it were to be regarded an L\&E, but there will still be a place for this provision in the copyright balancing exercise.

For the reasons provided previously, policy-based implied bare licences are not L\&Es and do not suffer from the constraints of the L\&Es. However, the common law powers under s 171(3) are broad and seemingly unguided, and therefore, courts can do well with taking methodological guidance from the three-step test. Although there are aspects of the test that are controversial, overall it can serve as a flexible guideline, as discussed in the section below.

\section{Flexibilities of Three-step Test}

While adopting the test, the agreed statement under art 10, WCT reiterated that the test is meant to be used to balance the competing interests, especially when a high level of protection is granted. ${ }^{44}$ The abstract criteria of the test were intended as a flexible guideline to formulate the L\&Es. ${ }^{45}$ Indeed, some commentators point out that the courts are in the best position to

\footnotetext{
${ }^{44}$ See WIPO Doc. CRNR/DC/4, para 12.09.

45 Geiger, Gervais and Senftleben (n 29) 4-7; Senftleben, 'EC Fair Use' (n 29) para [46].
} 
be the addressees of the three-step test, as they can make the best use of its open-ended abstract criteria, on a case by case basis. ${ }^{46}$ Others argue that the historical origins required the test to be vague, making it unsuitable as a guideline to the courts. ${ }^{47}$ However, the following paragraphs argue that it is possible to turn the high level of abstraction to flexible criteria for courts to apply. Accordingly, the courts of member states can interpret each criterion not only to achieve a just result, but also to realise the full potential of the test.

The decision of the WTO Panel on the US Copyright Act 1976, s 110(5)(b), the only authoritative ruling at the WTO level on the three-step test, is taken as a starting point, to propose an interpretation, keeping in mind the suggestions of commentators.

\subsection{Certain Special Cases}

The Panel interpreted 'certain' to mean 'clearly defined', and 'special cases' to mean 'limited in its field of application or exceptional in its scope' and 'narrow in both qualitative and quantitative sense.' However, importantly, it held that there was no need 'to identify explicitly each and every possible situation to which the exception could apply, provided that the scope of the exception was known and particularised'. ${ }^{48}$ This provides sufficient room for the courts to define a 'certain special case', based on the facts, circumstances and issues presented by each case. As Geiger, Gervais and Senftleben rightly point out: ${ }^{49}$

With every court decision, a further "special case" becomes known, particularized and thus "certain" in the sense of the three-step test. A sufficient degree of legal certainty thus may follow from established case law.

\footnotetext{
${ }^{46}$ Huaiwen He, 'Seeking a balanced interpretation of the three-step test' [2009] IIC 274, 306.

${ }^{47}$ Jonathan Griffiths, 'The “Three-step Test” in European Copyright Law - Problems and Solutions', [2009] IPQ 428, 429-30; Kamiel Koelman, 'Fixing the three-step test' [2006] 28 EIPR 407, 408.

48 Panel Rep. of 15 June 2000, United States-Article 110 (5) of the US Copyright Act, WT/DS160/R paras [6.108][6.109], [6.145] (WTO Panel).

${ }^{49}$ Geiger, Gervais and Senftleben (n 29) 33.
} 
Therefore, a court will have no difficulty satisfying this criterion. ${ }^{50}$ Further, the Panel says that the L\&E may be a special case even if it pursues a purpose whose normative justification cannot be discerned. Ricketson and Ginsburg argue that the normative justification will be tested by the second and the third steps. ${ }^{51}$ Therefore, the threshold for identifying a special case is low, and easily met.

\subsection{Conflict with normal exploitation of the work}

The Panel held 'normal exploitation' to involve copyright owners extracting economic value from their rights. ${ }^{52}$ The forms of exploitation include those that 'currently generate income for the rightholders as well as those which, in all probability, are likely to be of considerable importance in the future. ${ }^{53}$ The Panel further held that if the use permitted by the L\&Es competes economically with the use that the copyright owner could have made himself, then it violates the second step. ${ }^{54}$

The problem with this interpretation is its purely economic appreciation. Ricketson and Ginsburg argue that 'normal' should also mean 'normative' in that there may be forms of exploitation which a copyright owner should not be allowed, for other public policy reasons such as freedom of expression, research and scholarship. They argue that there should be a balance between economic and non-economic considerations before an exploitation can be regarded 'normal'. They argue that taking purely economic considerations will make the L\&Es recognised by the $\mathrm{BC}$ themselves invalid under the second step, resulting in the third step not

\footnotetext{
${ }^{50}$ Senftleben, 'EC Fair Use' (n 29) paras [51]-[53].

${ }^{51}$ Ricketson and Ginsburg (n 17) para [13.14].

${ }^{52}$ WTO Panel (n 48) para [6.165].

53 ibid para [6.180].

54 ibid para [6.183].
} 
being reached. Bringing non-economic considerations in the second step will mean that there may well be uses that do not conflict with what should be within the scope of normal exploitation of the work in a truly normative sense. Thus, one can create room beyond the purely individualistic interests of the copyright owner. ${ }^{55}$

Concerns have been raised because of the rejection of certain L\&Es by the courts in some EU member states based on a strict economic interpretation of 'normal exploitation'. ${ }^{56}$ Commentators equally note cases where courts have applied this criterion sensibly, ${ }^{57}$ but stress the need for rethinking this step, ${ }^{58}$ suggesting that a conflict with the normal exploitation should only be regarded as arising where copyright owner is deprived of an extensive share of her potential market. ${ }^{59}$

The Panel does recognise that the word 'normal' has both empirical and normative meaning. ${ }^{60}$ The Panel favoured the empirical (and economic) considerations since the exception being considered, namely exempting certain commercial establishments using home-style recording devices from payment of royalties for the music they played, did not require the kind of normative balancing that would be required for, say, a case involving a library or an educational establishment. The Panel did say that a normative meaning 'includes, inter alia, a dynamic element capable of taking into account technological and market

\footnotetext{
${ }^{55}$ Ricketson and Ginsburg (n 17) paras [13.20]-[13.22].

${ }^{56}$ Geiger, 'Dangerous Mutations' (n 37) 489-90; Griffiths, 'Problems and Solutions' (n 47) 433-36.

${ }^{57}$ Geiger, Gervais and Senftleben (n 29) 37-41.

58 Suggested alternatives range from reverse reading of the test to a possible new Declaration setting forth the interpretation of the test. ibid 17-30.

${ }^{59}$ Griffiths, 'Problems and Solutions' (n 47) 457.

${ }^{60}$ WTO Panel (n 48) para [6.166].
} 
developments. ${ }^{61}$ Therefore, there should be no reason to regard the outcome of the Panel's decision as the only way 'normal' can be interpreted in all circumstances. ${ }^{62}$

Sometimes, the extent to which the normative objectives can extend can become an issue. For example, it is unclear whether any subject matter that the public has a right to know, such as public health issue or business malpractices, ${ }^{63}$ are covered. Once the normative goal is identified under this step, balancing between such goals and copyright protection can be addressed in the next step.

\subsection{Unreasonable interfere with the legitimate interests of the right holder}

The Panel interpreted 'legitimate' to mean lawful from both a positivist and a normative perspective. Although in the exception being considered, the Panel focused only on the economic interests, the Panel clarified that legitimate interests are not necessarily limited to the economic value. Importantly, the Panel held that a certain amount of prejudice to the legitimate interests is justified, but not to an extent that it causes unreasonable economic loss. ${ }^{64}$

Ricketson and Ginsburg point out that not all interests, but only legitimate interests need to be considered, which means that interests that are permitted by law must be balanced with those that are legitimate at a normative level. All L\&Es cause prejudice to the exclusive rights, and therefore, only those that are unreasonable must be considered. ${ }^{65}$ Ricketson and

\footnotetext{
${ }^{61}$ ibid para [6.178].

${ }^{62}$ Graeme Dinwoodie, 'The Development and Incorporation of International Norms in the formation of Copyright Law' [2001] 62 Ohio St LJ 733, 756

${ }^{63}$ See section 3.2 below for more discussion.

${ }^{64}$ WTO Panel (n 48) para [6.224]-[6.229].

${ }^{65}$ Ricketson and Ginsburg (n 17) paras [13.24-13.25].
} 
Ginsburg argue that 'reasonable' means proportionate or within reason or is not unreasonable, and may impose conditions while balancing. ${ }^{66}$

Be it the assessment of the legitimacy or the proportionality of prejudice caused, courts are in a good position to conduct the balancing exercise, as they can do so on a case by case basis, and not rely on vast generalisations which the legislature must do. As confirmed by the Panel, in assessing what is a legitimate interest of a copyright owner, a holistic approach beyond the economic interests of the copyright owner, may be taken.

Thus, courts are in an ideal position to apply the three-step test. The following section will demonstrate how the test can be a methodological guideline in assessing public interest.

\section{Courts' Interpretation of Public Interest and Three-step Test}

The first half of this section reviews the case law, shedding light on the type of cases which have made the courts rise to the occasion. It reveals that the UK courts have historically exercised their power to restrict or prevent the enforcement of copyright in public interest. This power continued after the CDPA was enacted, and was acknowledged even after the Infosoc Directive was transposed. The second half goes on to consider these decisions in the light of the three-step test.

\subsection{Courts' Interpretation of Public Interest}

The following paragraphs deal with the cases on public interest decided before the enactment of s 171(3), and then move to those that arose under s 171(3). These cases have been categorised broadly under the public policy objectives pursued.

\footnotetext{
66 ibid para [13.26].
} 


\subsubsection{Objectionable nature of works}

Since at least $19^{\text {th }}$ century, courts have used copyright to censor works which they found to have objectionable content. ${ }^{67}$ This continued into the $20^{\text {th }}$ century when copyright protection was denied to a novel by Glyn called 'Three Weeks', which recounted the clandestine affair of the queen of a fictitious country. ${ }^{68}$ Glyn had complained of unauthorised use of her work by the defendant in their film. Although the court held that there was no such unauthorised use, in a dictum, it held that 'copyright cannot exist in a work of a tendency so grossly immoral. ${ }^{99}$

One may dismiss these cases as reflecting the values of those days, having no contemporary relevance. However, Glyn was relied on in Attorney General v Guardian Newspapers (Spycatcher). ${ }^{70}$ Here, an ex-employee of British Secret Service MI5, Peter Wright, wrote a book called 'Spycatcher', about the alleged irregularities and practices of the MI5, after his retirement from the services, for publication in Australia. The defendant newspaper, having obtained serialisation rights from the book's Australian publisher, published extracts of the book. The Attorney General sought to prevent this publication on the grounds of national security and Wright's breach of confidentiality. ${ }^{71}$ Much of the litigation was on the issue of whether the newspapers owed a duty of confidentiality.

The issue of concern here is the enforceability of Wright's copyright in Spycatcher. The House of Lords held that if Wright had tried publishing his book in the UK, he would

\footnotetext{
${ }^{67}$ Stockdale v Onwhyn [1826] 108 ER 65, where copyright was denied in an allegedly slanderous novel.

${ }^{68}$ Glyn v Weston Feature Film Co [1916] 1 Ch 261.

69 ibid, 269.

${ }^{70}$ [1990] 1 AC 109.

71 ibid 116, 120-123.
} 
have been restrained on the basis that it breached his duty of secrecy. ${ }^{72}$ Relying on Glyn, Lord Jauncey held that under these circumstances, no court in the UK would have enforced Wright's and his publishers' copyright in the book, and that anyone could copy the book in whole or in part without fearing infringement. ${ }^{73}$

Whilst Glyn and its previous authorities questioned the very subsistence of copyright in works of certain nature, Spycathcer only denied the enforcement of copyright. Section 171(3), which was enacted only months after the House of Lords decided Spycatcher, also only prevents or restricts the enforcement of copyright, and does not deny its subsistence. ${ }^{74}$ Indeed, in Yelland, Jacob J quoted with approval Lord Jauncey's approach to non-enforcement of copyright in certain cases. ${ }^{75}$

Note however, that in these cases, preventing or restricting the enforcement of copyright is an end in itself. Any authorisation that arises enabling users to make free use of the content whose copyright enforcement is refused, is only incidental, like in Spycatcher. These are not the cases where courts have refused copyright enforcement in order to enable the use of the copyright content in public interest. When the court adopts the latter approach, s 171(3) becomes the source for implying a policy-based licence, which leads us to the next section.

\subsubsection{Need for disclosure of the work in public interest}

It is said that copyright law 'filched' the public interest defence from the law of confidentiality. ${ }^{76}$ This is not entirely accurate because, as seen in the cases above, the notion

\footnotetext{
72 ibid 259.

73 ibid 294.

${ }^{74}$ See Vitoria (n 20) para [21.23]-[21.25] for a further discussion.

75 [1999] EWHC Patents 247 [24]; see also [2000] EWCA Civ 37 [62]-[63] (per Aldus LJ).

${ }^{76}$ Sims (n 6) 335.
} 
of public interest existed in copyright law long before. However, cases requiring disclosure of information in public interest arose first in the context of confidentiality. If confidentiality only extended to information, no copyright would subsist in it. However, given the continued lowering of the threshold for originality, the courts have realised that the same information in which confidentiality is claimed, could also be protected by copyright. In most cases, the existence of copyright was purely incidental, and there was little or no prospect of the copyright work in question being exploited independently. This explains why courts may not have wished for a copyright infringement claim to come in the way of a genuine need for the disclosure of confidential information. ${ }^{77}$

\subsubsection{From breach of confidence to copyright infringement}

In a classic case of breach of confidence like Initial Services Ltd v Putterill, the disclosure by an ex-employee of a launderette as to the price-fixing liaisons between his employer and other launderettes, was held to be in public interest. ${ }^{78}$ No claim for copyright infringement was or could be made in this case. Public interest in this line of cases is also narrowly defined to extend only to situations where the disclosure was necessary because of a crime, fraud or a misdeed committed or contemplated. ${ }^{79}$ The rationale perhaps is that the justification for secrecy disappears if secrecy is used to shield crime, fraud or misdeeds.

In the subsequent case of Hubbard $v$ Vosper, ${ }^{80}$ the defendant, an ex-follower of scientology, drew on books, letters and bulletins authored by the plaintiff (the founder of scientology), disclosed to the defendant whilst a follower, and wrote the defendant's own

\footnotetext{
${ }^{77}$ Burrell (n 6) 395-6.

${ }^{78}[1968] 1$ QB 396, 403.

79 ibid 405.

${ }^{80}$ [1972] 2 QB 84.
} 
critique of scientology. The plaintiff proceeded against the defendant for the infringement of copyright, and of confidentiality. ${ }^{81}$ In response to confidentiality claim, the defence of disclosure in public interest was upheld. The public interest defence to copyright infringement was not required since fair dealing was upheld. ${ }^{82}$

In Beloff $v$ Pressdram Limited, ${ }^{83}$ an internal memorandum written by the plaintiff, a correspondent of a newspaper, was reproduced and published by the defendant magazine. ${ }^{84}$ The memorandum contained discussions with cabinet ministers as to who should succeed the prime minister in the event of his accidental death. ${ }^{85}$ The plaintiff raised both breach of confidence and copyright infringement. The defendant raised public interest as a defence both to confidentiality and copyright infringement, apart from fair dealing.

Given the minimal literary quality of the memorandum, the court acknowledged that it was not a genuine case of copyright infringement. The confidential nature of the memorandum appeared stronger since it named the cabinet ministers as the source of plaintiff's information. ${ }^{86}$ The court treated the case as concerning confidentiality, couched in terms of copyright infringement. The court referred to both Initial Services and Hubbard in concluding that public interest would come into play only if there was a 'disclosure of iniquity. ${ }^{87}$ Since the memorandum did not disclose any iniquity or misdeed on anyone's part that needed to be covered up, the court held that no public interest would be served by its

\footnotetext{
81 ibid 92.

82 ibid 95.

83 [1973] FSR 33.

84 ibid 35.

85 ibid 54-55.

86 ibid 55-56.

87 ibid 56-58.
} 
disclosure. ${ }^{88}$ As the public interest defence was unsuccessful in relation to confidentiality, the court did not consider whether it was a defence to copyright infringement. However, it drove home the point that copyright could come in the way of a public interest defence to breach of confidence, if a similar defence was not recognised against copyright infringement. For this reason perhaps, this case finds a mention in the discussions of the House of Lords while drafting s 171(3). ${ }^{89}$

In Lion Laboratories Ltd $v$ Evans $^{90}$ the plaintiff carried on the business in selling Intoximeters, which were instruments used by the police for measuring intoxication by alcohol for road safety. Two of the defendants who were employees of the plaintiff, resigned from their positions and while leaving, took with them certain internal correspondence indicating the faulty calibration of Intoximeters giving incorrect results. The ex-employees gave the correspondence to the defendant newspapers for publication. Plaintiff sued them for breach of confidence and copyright infringement. ${ }^{91}$ There was no dispute as to the confidentiality of the correspondence, nor as to the plaintiff's ownership of copyright in it. The trial judge granted an injunction restraining the defendant newspapers from publishing, against which the defendants appealed.

Citing Initial Services and Hubbard, the Court of Appeal stated that the 'courts will restrain breaches of confidence and breaches of copyright unless there is a just cause or excuse for breaking the confidence or infringing copyright. ${ }^{92}$ It appears from this statement that the

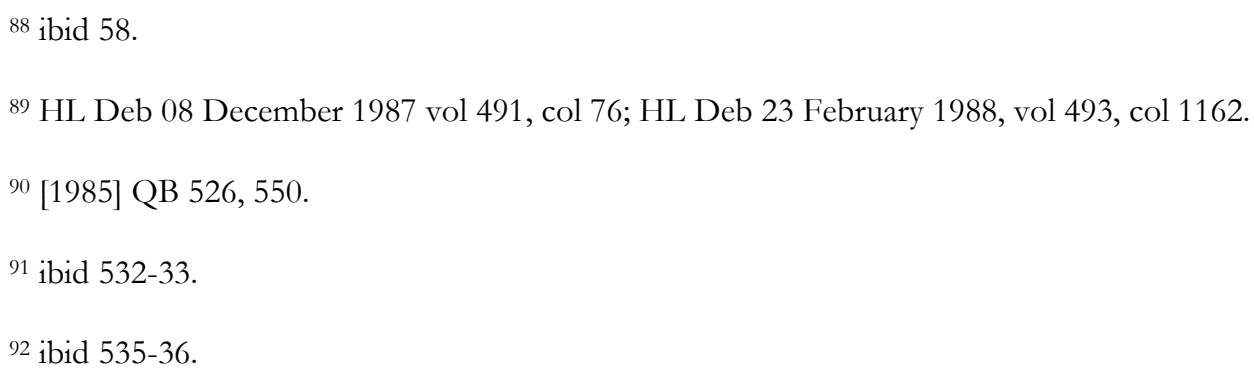


same defence would apply to both causes of action, albeit with different contours. A big part of Stephenson LJ's judgment is devoted to establishing the existence of public interest as a defence to confidentiality. He found that given the plaintiff's monopoly in supplying these instruments and the evidentiary value of their readings in criminal convictions, public had a genuine interest in knowing the fallibility of these instruments. ${ }^{93}$ To Griffiths LJ the defence of public interest was well established in relation to confidentiality, although he found less authority to support it as a defence to copyright infringement. He therefore regarded Hubbard and other cases as analogous, ${ }^{94}$ to conclude that the defence extended also to copyright infringement. Agreeing with Stephenson LJ, he went on to clarify that there was no requirement of iniquity, misdeed or criminality before a public interest defence could be established, ${ }^{95}$ since it was inconclusive whether the plaintiff had tried to cover up the faults with Intoximeters.

In holding that iniquity, misdeed or criminality was not a precondition to public interest defence, Lion showed foresight in acknowledging that public interest could arise in broader circumstances. In the language of licence, the court implied a bare licence in the defendants' favour, to reproduce and communicate the internal communication to the defendant newspapers, based on the public interest in the disclosure of the discrepancies in the Intoximeters.

The next logical step, with the passing of s 171(3), was to regard public interest as a defence to copyright infringement independent of breach of confidence. The cases discussed below were decided after the enactment of s 171(3), but without making a reference to it.

\footnotetext{
93 ibid 539.

${ }^{94}$ Such as Fraser v Evans [1969] 1 QB 349; Woodward v Hutchins [1977] 1 WLR 760.

95 ibid 550
} 


\subsubsection{Copyright infringement and public interest}

Unlike in the earlier cases where breach of confidence had helped determine the extent of public interest defence, in the cases discussed here, the extent of public interest defence to copyright infringement had to be independently considered. Courts initially took smaller steps in this direction while considering interlocutory injunctions in copyright infringement matters. Although these cases only concern interim remedies, Burrell argues that 'they are part of a wider picture which shows that the courts were clearly moving toward the recognition of such a defence. ${ }^{96}$

One such case was Beggars Banquet v Carlton, where the plaintiff was a record company, who had organised an all-night dance party, colloquially called a 'rave'. Plaintiff entered into an agreement with the second defendant, Spidercom, a film production company to create a film about the rave. During the event, a teenage boy died due to the consumption of the prohibited drug Ecstasy. ${ }^{97}$ The film was never completed, and Spidercom was not paid in full for its services. Spidercom approached the first defendant, Carlton, a television channel, and produced a documentary on the dangers of Ecstasy and the death of the teenager. The plaintiff approached the court for interlocutory injunction, among other pleas, to prevent the broadcast of the documentary, on the grounds of copyright infringement. ${ }^{98}$ The defendants raised public interest as one of the defences to the plaintiffs assertion of copyright, although s 171(3) was not expressly mentioned.

Although a significant issue was the ownership of the footage shot by Spidercom, Warren J concluded that there was an arguable case that the plaintiff was the sole or joint

\footnotetext{
${ }^{96}$ Burrell (n 6) 402.

97 [1993] EMLR 349, 353-6.

98 ibid 359-60.
} 
owner of the footage with Spidercom. ${ }^{99}$ Regarding the injunction restraining the broadcast of the documentary, Warren J acknowledged the defence of public interest, relying on Lion and Hubbard, among others, as pointing to an 'emerging jurisdiction'. He denied the injunction due to the public interest in conveying with 'vivid and telling' images the dangerous effects of Ecstasy and the goings on at rave parties. ${ }^{100} \mathrm{He}$ did this by reading public interest into the balancing exercise required for the grant of interim injunctions. He noted that any harm to the plaintiff is likely to be outweighed by the harm to the public interest if the broadcast is prevented. ${ }^{101}$ Therefore, in the language of licence, the court implied a licence in favour of the defendants, to reproduce and communicate the film footage to the public, based on the public interest in educating people on public health issues through its disclosure.

In Service Corporation International v Channel Four, an employee of a funeral services home conducted an undercover operation for the defendant television channel to disclose to the public the disrespectful and abusive treatment of the corpses carried out by the claimant. ${ }^{102}$ The plaintiff (SCI) sought a temporary injunction on the basis, inter alia, of copyright infringement. The defendant raised the defence of public interest. ${ }^{103}$ Lightaman J held that SCI did not have an arguable case on copyright ownership, since the employee had produced the film outside the course of his employment, without breaching any fiduciary duty. ${ }^{104}$ However, even if SCI could show its entitlement to copyright, he held that the defendants have an arguable case that the broadcast of the programme is in public interest. He held that the

\footnotetext{
99 ibid 364.

100 ibid 371-2.

101 ibid. Public interest was read into the test in American Cyanamid v Ethicon Ltd [1975] UKHL 1.

102 [1999] EMLR 83.

103 ibid 86-8.

104 ibid 90-91.
} 
defendant's film reveals 'a scandalous state of affairs and supports the defendants' case that the funeral home industry should be regulated as a matter of 'substantial public interest.' Although he mentioned neither s 171(3) nor any case law to support this conclusion, he factored in public interest in the balancing exercise to refuse injunction. ${ }^{105}$ Thus, assuming that the plaintiff was the copyright owner in the film, the court implied in favour of the defendant a licence to broadcast the film on the basis of the public interest in its disclosure.

From the initial steps of interlocutory injunctions, the courts went on to consider public interest in final judgments in copyright infringement cases. In PCR Limited $v$ Dow Jones Telerate Limited, the plaintiff claimed confidentiality and copyright infringement in its market reports on cocoa crops, which the defendant, a competing magazine, substantially copied in its articles. Defendant raised fair dealing and public interest defences. ${ }^{106}$ On the facts, it was found that the confidentiality claim was not tenable as the defendant did not know the confidential nature of the reports. ${ }^{107}$ Therefore, the defence of public interest had to be considered only for copyright infringement.

Lloyd J recognised that the public interest defence was more common in relation to breach of confidence, but acknowledged its independent existence under s 171(3) in relation to copyright cases. However, on the facts, Lloyd J was not convinced that requiring a total transparency in the cocoa market by allowing the defendant to copy and disclose the plaintiffs reports, was in public interest, considering the volatility it caused in cocoa prices worldwide. ${ }^{108}$

\footnotetext{
105 ibid 91-92.

106 [1998] FSR 170, 176-79.

107 ibid 180-81.

108 ibid 187-89.
} 


\subsubsection{Cases considering s 171(3), CDPA}

The cases in section 3.1.2.2 above show clearly that the courts had applied public interest as a defence to copyright infringement, without a claim for breach of confidence. Although these were only High Court decisions, the ability of the courts in defining and giving effect to public interest should not have been in doubt. However, Yelland ${ }^{109}$ took several steps backwards. Here, the plaintiff managed the security of Villa Windsor, a place visited by Princess Diana and Dodi Fyed the day before their death in a car accident. Certain still photographs of the Princess and Fyed derived from the claimant's security cameras during their visit to the Villa, had been given away by the claimant's employee to the defendant newspaper, without permission, allegedly to expose the falsehood surrounding their death. The plaintiff alleged copyright infringement, but not breach of confidentiality. ${ }^{110}$ The defendant raised the defence of fair dealing and public interest.

Jacob J upheld the claim of fair dealing, but also dealt with the public interest defence since it had been argued before him. He disagreed with the claim that no defence of public interest exists. While recognising the close connection that the defence has with confidentiality cases, he clarified that the defence is narrow and applies only in cases where no right-thinking person would conclude otherwise, and that the disclosure must be proportionate to the public interest. ${ }^{111}$ On the facts, Jacob J held that the public interest defence had been made out for the same reasons as the fair dealing defence. This is problematic. Even if in principle the public interest defence exists, for it to be successfully claimed, if it takes the same or similar facts as

\footnotetext{
109 [1999] EWHC Patents 247.

110 ibid [1]-[8].

111 ibid [30], [40]. Jacob J relied on Australian decisions in The Commonwealth of Australia v John Fairfax (1980) 147 CLR 39 and Acohs v R A Bashford Consulting (1997) 144 ALR 528.
} 
the fair dealing defence, then there is no independent utility of public interest defence.

When the plaintiff appealed, the Court of Appeal began by distinguishing the extent of the public interest defence for copyright infringement in the absence of breach of confidence. To Aldous LJ, the difference lied in the fact that if confidential information is disclosed in public interest, the very foundation of the action disappears. But the disclosure of a copyright work does not destroy the foundation of an action in copyright infringement. In this sense, he held that the breadth of public interest defence for confidentiality is not comparable to that for copyright infringement. ${ }^{112}$ For Mance LJ, public interest as a defence to confidential information was born out of freedom of expression and information; and copyright did not 'lie on the same continuum as, nor was it the antithesis of, freedom of expression', and therefore the protection of copyright could not be 'weighed in the same direct way against a public interest in knowing the truth'. ${ }^{113}$ This reasoning is problematic because copyright can be an antithesis to freedom of expression and information. ${ }^{114}$

Technical differences may exist between how a defence of public interest arises in breach of confidence cases and copyright infringement cases. But, in principle, there is no reason why copyright enforcement should not be denied for similar reasons as for denying confidentiality, namely the disclosure/publication being in public interest, which is assessed based on the facts of each case. The cases discussed before Yelland comfortably dealt with the public interest defence in copyright law, without being influenced by these technical differences, which the court failed to recognise.

\footnotetext{
112 [2000] EWCA Civ 37 [64].

113 ibid [76].

114 See generally, section 4.1 .2 below.
} 
Aldous LJ acknowledged the existence of the defence of public interest to copyright infringement, but held it to be limited to cases where enforcement of copyright would 'offend against the policy of the law. ${ }^{115}$ However, while admitting that the circumstances under which the public interest defence would come to play are not capable of definition, Aldous LJ still went ahead to enumerate these circumstances thus: where the copyright work is immoral, scandalous or contrary to family life, or is injurious to public life, public health and safety or the administration of justice. ${ }^{116}$ Mance LJ disagreed and held that public interest defence is not capable of precise categorisation. ${ }^{117}$ Stuart-Smith LJ gave a one line judgment agreeing with Aldous LJ.

This decision is problematic: firstly, the categorisation of public interest is unjustified. There is a reason why s $171(3)$ is broadly worded - to give the courts the maximum flexibility in assessing each case on its own facts. The legislative history of s 171(3) also supports this. ${ }^{118}$ Secondly, and substantively, the categories are clearly quite narrow. They represent only the line of cases captured in section 2.4.1 above, where copyright enforcement is refused because the content is objectionable, and not because the public should benefit from its disclosure. This suggests that regardless of a claim for breach of confidence, there is no public interest defence that extends to copyright infringement if the objective is disclosure in public interest. Thirdly, it pays no heed to the High Court decisions that had already recognised public interest defence, independent of a claim in confidentiality, such as Beggars and SCI. ${ }^{119}$ Instead, as we

\footnotetext{
115 [2000] EWCA Civ 37 [64].

116 ibid [66].

117 ibid [83].

118 See section 1.1 above.

119 Burrell (n 6) 402.
} 
will see below, this case set a bad precedent.

It is no surprise therefore, that on the facts, the Court was unanimous in holding that no defence of public interest (nor of fair dealing) was established. ${ }^{120}$ The decision drew much criticism for not appreciating that the public interest in exposing the lies surrounding the death of 'a future sovereign's mother', outweighed the copyright protection in the photographs, which, in any event, were captured due to no exercise of human creativity. ${ }^{121}$ A policy-based licence should have been implied in favour of the newspapers to publish the photographs.

The combined question of confidentiality and copyright arose again in Ashdown $v$ Telegraph Group Limited. ${ }^{122}$ The claimant was a leader of a political party, and had authored the minutes of a confidential meeting with the then prime minister of the UK. He was in the habit of keeping diaries of his political career, which he later wanted to publish as a book. He had disclosed the minutes to a group of journalists and publishers for this purpose, strictly under confidence. However, the minutes leaked and the defendant newspaper carried a feature, quoting extensively from the minutes. The claimant sued for breach of confidence and copyright infringement, claiming injunction and damages. The defendant claimed the defence of fair dealing and public interest. ${ }^{123}$

Denying the defendants a defence in both fair dealing and public interest, the High Court granted the plaintiff a summary judgment. As to public interest defence, the Court regarded Aldous LJ's enumeration in Yelland of circumstances under which public interest defence could be exercised, as the majority view binding on the Court. It held that the facts of

\footnotetext{
120 [2000] EWCA Civ 37 [77]-[79].

121 Sims (n 6) 338.

122 [2001] Ch 685. The application of the HRA raised in this case is discussed in section 3.2.2 below.

123 ibid [1]-[5].
} 
the case did not fall within any of those categories. ${ }^{124}$ This decision is a clear example of the damage done by Aldous LJ's judgment.

The Court of Appeal, however, held that the High Court's strict adherence to the list of circumstances enumerated by Aldous LJ was unjustified, as Mance LJ had disagreed with him and Stuart-Smith LJ had not expressed a specific opinion. As such, the Court went on to regard Lion as the authority on the point. Upon analysing the judgment, it held that two of the three judges in Lion had recognised a defence of public interest even when there was no moral turpitude. The Court therefore, endorsed Mance LJ's views that the circumstances in which public interest defence can be claimed are not capable of precise enumeration. ${ }^{125}$

This decision would have brought back to some extent, the flexibility and breadth of s 171(3). However, it held that the fair dealing defence under s 30, CDPA would 'normally afford the court all the scope' it needs to reflect public interest in freedom of expression, and therefore, there would be no need to consider separately the public interest defence under section 171(3). ${ }^{126}$ Although it held that with the passing of the HRA, there is a clear public interest in protecting free speech, it regarded such cases to be very rare. ${ }^{127}$

On the facts, the Court concluded that the defence of public interest was not made out. The Court observed that there was no justification for the defendant to have used the exact words of the minutes. They could have used their own words to describe the contents of the minutes, especially since there were other newspapers which reported the same event

\footnotetext{
124 ibid [32].

125 [2001] EWCACiv 1142 [51]-[58].

126 ibid [66].

127 ibid [58].
} 
without quoting extensively from the minutes. ${ }^{128}$ This interpretation is too restrictive. The cases which do not come under fair dealing for not being criticism, review or reporting current events, and where the authenticity of journalism demands verbatim copying, are exactly the type of cases that s 171(3) must save from infringement. ${ }^{129}$

The decision in Ashdown was applied in HRH Prince of $W$ ales $v$ Associated Press, where the Prince had maintained a journal of his travels, copies of extracts of which were sent to certain members of his staff strictly in confidence. A member of his staff allegedly gave an extract of Prince's journal to the defendant newspaper, which published articles incorporating extracts from the journal. The Prince sued for breach of confidentiality and infringement of copyright. ${ }^{130}$ The defendant raised the defence of fair dealing and public interest. ${ }^{131}$

The court relied on Ashdown to hold that the defence of public interest was only available in rare cases where verbatim reproduction would be required, and that the facts here did not present such a case. If there were no prospects of a successful claim of fair dealing, it was unlikely that a claim of public interest could succeed. ${ }^{132}$ This decision is problematic: if there were prospects of fair dealing being successful, then there would be no need for a public interest defence. This decision introduces an artificial hierarchy between fair dealing and public interest defence. Nevertheless, this case is still important because it arose after the Infosoc Directive was transposed to the CDPA. Although it did not enforce public interest under s 171(3), it acknowledged its existence and application, even if in very rare cases.

\footnotetext{
128 ibid [79]-[81].

${ }^{129}$ Quoting from protected text is now covered by fair dealing to some extent under CDPA, s 30(1ZA), post 2014 amendments to the CDPA.

${ }^{130}$ [2006] EWHC 522 (Ch) [1]-[6].

131 ibid [162], [178]

132 ibid [179]-[180].
} 
The reigning theme in the above cases is the disclosure of copyright work in public interest. By no means public interest is confined to the disclosure of copyright works, free speech or press freedom. The line of cases below on spare parts exception show how broad the application of public interest can be. ${ }^{133}$

\subsubsection{Spare parts exception}

Chapter VI addressed, inter alia, licence to repair a product that incorporates a copyright work. If repair involves reproduction of the work, implied into the contract of purchase of the product, is a licence permitting the reproduction of the copyright work to effect repairs. We saw that if the person repairing is a third party rather than the purchaser of the product herself, the license to repair could be sub-licensed, so that the purchaser of the product can authorise someone else to repair. However, economic efficiency requires the person repairing the product to manufacture spare parts in advance of receiving an order. Here there is no contract into which a licence permitting copying of the work can be implied before the manufacture of such spare parts. In these circumstances, it might be possible to imply a bare licence from the copyright owner in favour of the spare parts provider, bypassing the purchaser of the product, to achieve the policy objective that the purchaser of the product should have access to the most economical and efficient way to repair her product.

This situation first arose in British Leyland Motor Company Ltd v Armstrong Patent Co Ltd, where the plaintiff (BL), a car manufacturer, had asserted its claim to copyright in the design of the spare parts, and had compelled many spare parts manufacturers to become licensees and pay royalties on sales of spare parts. However, the defendant (Armstrong) had always resisted becoming a licensee. BL claimed that Armstrong had reverse engineered and copied

\footnotetext{
133 See Lord Beaverbrook's comments in (n 35) above.
} 
BL's exhaust pipes, thereby infringing BL's copyright in the design of the exhaust pipe. ${ }^{134}$ The question was whether there was anything in the law to prevent BL from asserting its copyright to prevent Armstrong from reproducing the exhaust pipe design.

Solar Thomson Engineering Co Ltd v Barton ${ }^{135}$ was distinguished on many points, including that in this case the exhaust pipes were not patentable. In addition, at issue in Solar was expensive machinery to which spare parts would be manufactured in response to a specific order of a purchaser of the machine, and not in advance in anticipation of the need. ${ }^{136}$ In the Court of Appeal, Oliver LJ was prepared to accept that the purchaser of a BL car might himself copy, or commission another to copy the original exhaust pipe to provide replacements. He was willing to accept also that the implied licence could extend if the purchaser wanted two or three spare parts made in anticipation of future breakdowns. However, he found it impossible to derive from this a blanket licence in favour of any member of the public to copy the design of exhaust pipe, in the absence of a specific order. Therefore, Oliver LJ rejected that an implied licence can rest on contractual basis. ${ }^{137}$

Lord Bridge in the House of Lords articulated two policy considerations: firstly, that the owner of a car must be entitled to do whatever is necessary to keep it in running order and to effect whatever repairs may be necessary in the most economical way possible. He found that 'it is a right inherent in the ownership of the car itself and 'to curtail or restrict the owner's right to repair in any way may diminish the value of the car. ${ }^{338}$ Secondly, he observed that BL

\footnotetext{
134 [1986] 1 All ER 850, 854.

135 [1977] RPC 537.

${ }^{136}$ See Chapter VI, section 2.1 above.

137 [1984] FSR 591, 611-12.

138 [1986] 1 All ER 850, 861
} 
have already enjoyed the primary benefit which their copyright protects when they sell cars fitted with exhausts based on their copyright drawings. To allow them to enforce their copyright to maintain a monopoly for themselves and their licensees in the supply and replacement of exhausts detracts from the car owners' rights and, at least potentially, the value of their cars. ${ }^{139}$

But how does the entitlement to repair inherent in the ownership of a car translate to a general privilege of any member of the public to produce spare parts in advance and not in response to an order? Both Lord Bridge and Lord Templeton found their answer in the doctrine of non-derogation from grant, whereby the sale of the car was the grant, and to assert copyright over its spare parts was to derogate from that grant, ${ }^{140}$ because it makes the repair more expensive, thereby diminishing the value of the grant.

However, this still does not translate to any member of the public being able to produce spare parts in advance, for several reasons. Non-derogation is for the benefit of the purchaser of the car. In Hohfeldian terms, if the grant is of the car together with a right against derogation, and a corresponding duty on BL not to derogate, it still does not explain why this right acquired by each car owner translates generally to any member of the public having a privilege to produce spare parts in advance. If the grant is of the car together with the privileges associated with the car, and BL has no-right to derogate from them, we are speaking the Hohfeldian language of licence here. If one argues that the car purchaser's licence is sublicensed to the third party spare parts manufacturer, then we have the same problem raised in Chapter VI above - how does the third party spare parts manufacturer get her licence to produce spare parts in advance? Even if one regards the non-derogation as being in rem, the

\footnotetext{
139 ibid 862

140 ibid 873.
} 
duty not to derogate or the no-right to derogate will only arise once there is a grant, and not in advance of the grant.

A plausible explanation is that the policy objectives identified by Lord Bridge justify the implication of a bare licence in favour of any member of the public to produce spare parts in advance, to achieve the policy of providing the most economical and efficient repair services possible. On this view, the doctrine of non-derogation from grant is irrelevant. Therefore, without questioning the usefulness of this doctrine in other circumstances, this thesis will not discuss this doctrine further.

Lord Hoffman in Canon Kabushiki Kaisha v Green Cartridge Co (Hong Kong) Ltd ${ }^{141}$ observed that British Leyland was neither founded on property nor on contract, but on an overriding principle of public policy; namely, the need to prevent a manufacturer from using copyright to control the market in spare parts. ${ }^{142}$ He did not refer to s 171(3), CDPA, nor the case law under it, because the case was before the Privy Council dealing with Hong Kong law. However, in Mars UK Ltd v Teknowledge $L t d{ }^{143}$ although Jacob J was willing to accept that there is a public interest defence that applies to cases of repair, he held on the facts that it did not meet the test of 'no right thinking member of society would quarrel with the result'. ${ }^{144}$

As discussed in Chapter VI above, many instances of licence to repair are codified, with some of the provisions enacted because of British Leyland. ${ }^{145}$ Accordingly, in Mars, which concerned defendants having reverse engineered a coin recognition software, Jacob, J held

\footnotetext{
141 [1997] AC 728.

142 ibid 737.

143 [1999] EWHC 226 (Pat).

144 ibid [23], relying on his own ruling in [1999] EWHC 247 (pat) [39].

145 See Chapter VI, section 2.1.3.
} 
that he could not rely on s 171(3) to override statutory exceptions specific to computer programmes in the CDPA. ${ }^{146}$ Commentators argue that spare parts exception may no longer exist under the UK copyright law. ${ }^{147}$ However, similar to the arguments in Chapter VI above, the codification does not take away the powers of the courts in circumstances not covered by the statutes, to imply a policy-based bare licence.

The foregoing discussion reveals that in general, the courts have approached public interest more conservatively than ambitiously. Since there are no guidelines for the exercise of the courts' power, the section below takes a retrospective look at whether the courts comply with the three-step test in the subtext. The effort will be to show how the test can act as a methodological guideline.

\subsection{Three-step Test as a Methodological Guideline}

Let me examine each step of the test. Courts have defined 'certain special cases' with due care, in confining the findings of fact and law to the circumstances of the case. Even when public interest exception came into its own without being overshadowed by confidentiality, such as in Beggars and SCI, the cases were well defined within the facts presented by the respective case. Spare parts cases, in any event apply to a very specific scenario, as described above.

Regarding the conflict with the normal exploitation of the work, the public interest defence was successful only in Lion, Beggars, SCI and British Leyland. In Lion (internal correspondence) and SCI (undercover video footage), the work did not have any prospect of being exploited by its copyright owner, either because of the nature of the content or because the copyright owner was not in the business of exploiting it.

\footnotetext{
${ }^{146}$ Mars (n 143) [18]-[19]. Software specific exceptions are CDPA, ss 50A-50C.

147 Gavin Llewellyn, 'Does Copyright Recognise a Right to Repair?’ [1999] EIPR 596, 599.
} 
In Beggars, the video footage could have been economically exploited by its copyright owner. However, the implied licence in favour of the defendants to use the footage in a documentary extended only to its uninterrupted broadcast by denying a preliminary injunction, leaving the copyright owner to a remedy in damages. ${ }^{148}$ Therefore, by pursuing a claim in damages, the copyright owner could have obtained the economic value of the very broadcast that was allowed by the refusal of injunction. Indeed, the court refused to allow defendants to make further use of the footage, limiting the licence to the broadcast already made. ${ }^{149}$ Therefore, the court's enforcement of public interest did not interfere with the normal exploitation of the work.

Had Beggars proceeded to trial and the court had to decide whether to grant damages, then it would have been essential to read normativity into normal exploitation. The question to ask would be whether the objectives such as the public's right to know and be educated by issues of public health should be allowed to interfere with the exploitation of the work by the copyright owner. It may have been difficult for the court to deny damages because of the difficulty in stretching the normative aspect of normal exploitation to this extent.

Although reading public interest into remedies is a more practical approach in some cases, by no means is the scope of the common law rule under s 171(3) limited to remedies. ${ }^{150}$ The effect of British Leyland was to permit Armstrong to continue to use BL's designs without having to pay any compensation, although $\mathrm{BL}$ was exploiting these designs. However, the normative need for the owners of chattels to have access to economical and efficient supply of spare parts for repair was regarded much higher than the need for economic exploitation

\footnotetext{
148 An approach supported in Ashdown [2001] EWCA Civ 1142 [46] and HRH (n 130) [186]-[187].

149 Beggars (n 97) 372-73.

150 Burrell (n 6) 402; Sims (n 6) 341.
} 
of copyright in the design. It is debatable whether the normative aspect of normal exploitation extends to this extent.

In cases like Beloff and Ashdown (minutes), and Yelland (CCTV photos), the possibility of independent exploitation of the work at issue was very low. Thus, in these cases, the courts could not have fallen foul of the second step, even if they had upheld the public interest defence.

As for the balancing exercise required to assess the prejudice to the legitimate interests, the interest of the public in Lion, Beggars, SCI and British Leyland, were far more significant than those of the copyright owners, requiring the balance to tip in favour of public interest. In Yelland and Asbdown, public interest in seeing the actual CCTV photos or read the minutes verbatim, could have been better balanced.

In summary, courts have conservatively and there is still sufficient room in the third step for the courts to expand considerations of public interest in the balancing exercise.

When a case meets the three-step test, normally it leads to a result that is compliant also with the FR regime. This is because the considerations factored within the balancing exercise undertaken in the third step are akin to those under the FR regime, ${ }^{151}$ as we shall see below. However, even if a case does not comply with the three-step test (especially the second step), a court can still proceed to examine it for compliance with the FR regime. This is because, firstly, the three-step test is suggested here only to guide the methodology of implication, and not as an obligation. Secondly, the origin of the three-step test is within the copyright context, and it operates as a response to copyright infringement. The FR regime, on the other hand, is not limited to the copyright context, but has much broader application.

151 Geiger, Gervais and Senftelben (n 29) 24. 
Further, as a provision in a directive, the three-step test itself is subject to a scrutiny by the FR regime. ${ }^{152}$ Therefore, if the three-step test was not satisfied in cases like Beggars and British Leyland, the FR regime might still be able to support the implication of a policy-based bare licence. This leads us to the discussion on the FR regime below.

\section{Interpretation of Public Interest and Fundamental Rights Regime}

The legal landscape of the FRs in the UK includes the ECHR and the CFREU. The ECHR has established the ECtHR to ensure observance of the ECHR by its signatories. ${ }^{153}$ As a signatory to the ECHR, the UK has enacted the HRA bringing into effect domestically the FRs guaranteed under the ECHR. All EU institutions, including the CJEU must act in compliance with the CFREU while implementing and applying EU law. ${ }^{154}$ In this sense, the reach of the ECHR goes further than implementing or applying EU law, unlike the CFREU. While the ECtHR's decisions are binding only on the parties to the dispute, ${ }^{155} \mathrm{~s} 2(1)(\mathrm{a})$ of the HRA requires the UK courts to 'take into account' these decisions. The CJEU's preliminary rulings interpreting the Treaties and the acts of the EU institutions (including Directives), ${ }^{156}$ are binding on the UK courts. ${ }^{157}$

To the extent that it is argued in section 1.3 above that Infosoc Directive does not affect the common law powers of the courts under s 171(3), the decisions of the CJEU should

\footnotetext{
${ }^{152}$ See Chapter II, section 3.3.2.2 above.

153 ECHR, art 19.

154 CFREU, art 51(1).

155 ECHR, art 46(1).

156 TEU, art 267.

${ }^{157}$ Recommendations to national courts in relation to the initiation of preliminary ruling proceedings [2012] OJ C338/12.
} 
not matter to the courts while exercising their powers under s 171(3). Further, when the UK leaves the EU, if it does not renegotiate the membership of the internal market, the CFREU will cease to apply, although the ECHR will continue to apply. But, since the CJEU had more opportunity to engage with the application of the CFREU to copyright than the ECtHR, CJEU's decisions provide a good guideline. Therefore, in their interpretation of the common law rule under s 171(3), the UK courts must take into account the provisions of the HRA, the decisions of the ECtHR, and may take guidance from the decisions of the CJEU to the extent applicable to the subject matter of the case.

\subsection{Fundamental Rights Methodology}

There are two stages to the assessment of the impact of the FRs - applicability, addressing the kind of disputes to which the FR regime applies; and compatibility, addressing whether the impugned law/state action is compatible with the FR regime. ${ }^{158}$

\subsubsection{Applicability}

Scholars have identified two broad kinds of disputes: ${ }^{159}$ vertical, where a direct state action is involved and where the state is a party to the proceeding against a private person; and horizontal, where the dispute is between private parties, but the validity or the interpretation of the law applicable to them is challenged as being incompatible with the FRs. The disputes of concern here are horizontal, which involve persuading a court to imply a policy-based bare licence between private parties.

158 See generally, Amy Goymour, 'Property and housing' in David Hoffman, The Impact of the UK Human Rights Act on Private Law (CUP 2013) 251.

${ }^{159}$ For example, ibid 252-3. 
Horizontal applicability of the ECHR has been controversial in other areas of law. ${ }^{160}$ However, in intellectual property disputes it has been less so. In Anheuser-Busche Ltd v Portugal, the ECtHR has held that a state has a positive obligation to take measures to protect property including intellectual property, by ensuring that judicial procedures respect the right to property even in a dispute between private parties. ${ }^{161}$

Regarding the horizontal applicability of the CFREU, again issues exist in other areas of law. ${ }^{162}$ However, the applicability of the CFREU to intellectual property disputes is well accepted. Indeed, there is a growing number of cases, such as Cases C-314/12 UPC Telekabel $v$ Constantin Film, ${ }^{163}$ C-201/13 Deckmyn v V anderstee, ${ }^{164}$ and C-484/14 McFaddn v Sony Music, ${ }^{165}$ to name a few, where the CJEU has held that in interpreting and applying EU directives, the national courts must comply with the CFREU.

\subsubsection{Compatibility}

Once a dispute is found to be of the kind to which the FR regime applies, we then assess compatibility. This assessment deals with the manner in which the ECtHR and the CJEU have interpreted copyright law in an FR-compatible manner. Although the decisions discussed below address issues different from policy-based implied licences, the approach adopted in

\footnotetext{
160 Alison Young, 'Mapping horizontal effect' in David Hoffman, The Impact of the UK Human Rights Act on Private Law (CUP 2013) 16-22.

161 [2007] 45 EHRR 36 [83].

162 Alison Young, 'Horizontality and the EU Charter' (UK Constitutional Law Association, 29 January 2014) <https://ukconstitutionallaw.org/2014/01/29/alison-young-horizontality-and-the-eu-charter/> accessed 19 November 2016.

163 [2014] ECDR 12.

164 [2014] WLR(D) 385.

165 [2016] WLR(D) 494.
} 
these decisions may influence the UK courts' own approach.

\subsubsection{ECtHR's Approach}

The ECtHR, being a specialised court for human rights with a longer history, has its own approach to compatibility. Scholars identify three main questions in this regard: ${ }^{160}$

- is/are an FR/s engaged in the dispute?

- is there an interference with the FR?

- is the interference justified?

Regarding the specific right/s engaged, the ECtHR has held that copyright (and indeed other forms of intellectual property) are protectable as possessions under art 1 of the First Protocol (A1P1). ${ }^{167}$ Since a policy-based licence, if implied, is in response to a claim of copyright infringement, A1P1 will be engaged. A1P1 says that every natural or legal person is entitled to the peaceful enjoyment of his possessions. The $2^{\text {nd }}$ and $3^{\text {rd }}$ sentences of A1P1 recognise two types of interferences - deprivation of property and control of use. Deprivation includes expropriation and is more invasive. Control of use encompasses lesser restrictions. ${ }^{168}$ The concern here is control of use by way of licences, and not deprivation by extinguishing copyright interest. An interference by way of control of use can only be justified by a law in 'general interest'. Such interference will be justified if it can be shown that the means employed by the state is proportionate to the objectives it seeks to achieve. ${ }^{169}$

\footnotetext{
${ }^{166}$ Laurence Helfer, 'How Intellectual Property and Human Rights Can Live Together' in Paul Torremas (ed), Intellectual Property Law and Human Rights (3 ${ }^{\text {rd }}$ edn, Wolters Kluwer 2015) 39; see also Amy Goymour (n 158) 274.

167 Dima v Romania, App No 58472/00 (ECtHR, 26 May 2005) on copyright and Anheuser-Busch (n 161) on trademarks.

${ }^{168}$ Helfer (n 166) 36-37.

169 ibid 37-38.
} 
Scholars regard proportionality to be not a simple formula, but a complex matter requiring a thorough analysis. ${ }^{170}$ In theory, proportionality can be achieved in three ways: where the interference is suitable, necessary or strikes a fair balance among competing interests. ${ }^{171}$ Thus far, in relation to copyright cases the ECtHR has only applied the second and the third means. An interference is necessary if there is no other measure which is less onerous. However, the ECtHR has only applied this principle if a prima facie interference has been established, ${ }^{172}$ as discussed below. Scholars believe that the ECtHR generally prefers the method of striking a fair balance to achieve proportionality. ${ }^{173}$ However, in many cases, the ECtHR adopts a deferential approach in allowing the national courts a wide margin of appreciation in adopting proportionate measures, as illustrated below.

Dima $v$ Romania was a case of deprivation of possessions, where the issue was whether national symbols attract copyright protection. ${ }^{174}$ The ECtHR held that in principle, copyright is protected as 'possessions' within A1P1. However, the ECtHR held that there was no interference with Dima's possessions because the Romanian courts had a margin of appreciation in interpreting the Romanian law, which was unclear as to the copyright protection extended to national symbols. ${ }^{175}$

In Balan v Moldova, on the other hand, where the state had used a photograph which Balan had taken without compensation, the ECtHR held this to be an unjustified interference

\footnotetext{
${ }^{170}$ Jonas Christoffersen, 'Human Rights and balancing: The principle of proportionality' in in Christophe Geiger, Research Handbook on Human Rights and Intellectual Property (Edward Elgar, 2015) 19.

171 ibid 20.

172 ibid 21-25.

173 ibid 35-36; see also Helfer (n 166) 37-38.

${ }^{174}$ Dima (n 167).

175 ibid para [78].
} 
with Balan's A1P1 right in his photograph. ${ }^{176}$ The ECtHR further held that Moldova could have used a less invasive option by issuing their identity cards by not using Balan's photo, and therefore, Moldova's actions were not proportionate. ${ }^{177}$

Sometimes, in its assessment of whether an interference is justified, not only is a court required to assess whether the deprivation of one party's right to property is justified, but also whether the other party's own fundamental right should be protected. One of the most common competing right put forward is the right to freedom of expression and information under art 10(1). Article 10(2) sets forth a variety of circumstances in which it would be justified to restrict this freedom if prescribed by law. This includes the necessity in a democratic society, in the interests of national security, territorial integrity or public safety, protection of reputation or rights of others, and so on. Therefore, an assessment of fair balance and proportionality will also involve these additional considerations. The following cases illustrate how fair balance is approached when there are conflicting rights.

The cases that have arisen so far, namely, Ashby Donald v France, ${ }^{178}$ and Frederik Neij v Sweden, ${ }^{179}$ both concern criminal convictions for copyright infringement. When the convicted infringers claimed their right to freedom of expression under art 10, in both cases the ECtHR held that the interference was justified since it was prescribed by law and pursued the legitimate aim of protecting the property rights of copyright holders and can be considered necessary in a democratic society. In both cases, the ECtHR held that the domestic courts have a wide margin of appreciation in balancing between the right to freedom of expression and right to

\footnotetext{
176 App no 19247/03 (ECtHR, 29 January 2008).

177 ibid paras [7]-[18].

178 App no 36769/08 (ECtHR, 10 January 2013).

179 App no 40397/12 (ECtHR, 19 February 2013).
} 
property, in securing these convictions. ${ }^{180}$

Copyright in most cases will qualify as 'the rights of others' whose protection is necessary in a democratic society. This might convey that the threshold for establishing art 10 right against copyright is particularly high. However, the ECtHR in other contexts has affirmed that the member states have a positive obligation to protect art 10 against interferences by private persons or corporate organisations. ${ }^{181}$ Further, art 10 protects not only the freedom to hold opinions, but also 'to receive and impart information and ideas without interference by public authority and regardless of frontiers.' As such, the right takes on an additional dimension on the internet. Indeed, the ECtHR recognises the importance of the internet in enhancing the public's access to and dissemination of information, and as 'the principal means by which individuals exercise their right to freedom of expression and information. ${ }^{182}$

Therefore, art 10 can act as 'an external constraint' on the scope of copyright protection, ${ }^{183}$ and a powerful tool in the hands of users of copyright content in both online and off-line contexts. Since the ECtHR gives a wide margin of appreciation to the domestic courts in striking a fair balance between competing rights, the onus is on the domestic courts to use art 10 to its fullest potential.

\subsubsection{CJEU's approach}

Article 52(3), CFREU states that the substantive content of the rights in the CFREU correspond to those in the ECHR. The CFREU guarantees protection specifically for

\footnotetext{
${ }^{180}$ Henning Grosse Ruse-Khan, 'Overlaps and conflict norms in human rights law' in Christophe Geiger, Research Handbook on Human Rights and Intellectual Property (Edward Elgar, 2015) 86-7.

181 Wojtas-Kaleta v Poland App no 20436/02 (ECtHR, 16 July 2009); see also Voorhoof (n 30) 335.

182 Times Newspapers Ltd v UK (Nos 1 and 2) App nos 3002/03 and 23676/03 (ECtHR, 10 March 2009); Ahmet Yildirim v Turkey App no 3111/10 (ECtHR, 18 December 2012).

183 Voorhoof (n 30) 331.
} 
intellectual property under art 17(2), in a seemingly absolute way. ${ }^{184}$ However, art 52(1) acknowledges that the rights guaranteed in the CFREU also have limits, and any such limitations should be provided for by law, must respect the principle of proportionality, and must be in the general interest or protect the rights of others. Unlike the ECtHR, which adopted three different ways to achieve proportionality, ${ }^{185}$ the CJEU has adopted only the method of striking a 'fair balance' in furthering proportionality, which in the copyright context is enshrined in recital 31, Infosoc Directive. In addition, recital 3, Infosoc Directive, identifies the protection of intellectual property, freedom of expression and public interest as the fundamental principles of law, pointing to the main interests that need to be balanced in a specific case.

The CJEU's striking a fair balance must bring about a similar result to the ECtHR striking a fair balance. This is because, art 53, CFREU requires that the provisions of the CFREU shall not be interpreted in a manner restricting or adversely affecting the FRs recognised by the member states as the signatories to the ECHR. Therefore, read with art 52(3), the interpretation of the CFREU cannot result in a different scope of the rights under CFREU than under the ECHR.

Scholars question the methodology behind the striking of fair balance and the consistency with which the CJEU has applied it. They argue that the CJEU has struck a fair balance on an ad hoc basis, and that in certain cases (such as Svensson), the CJEU should have expressly attributed its reasoning to a fair balance needing to be struck. ${ }^{186}$ Although consistency

\footnotetext{
${ }^{184}$ Christophe Geiger, 'Intellectual Property Shall be Protected!? Article 17(2) of the Charter of Fundamental Rights of the European Union' [2009] EIPR 113-17.

185 The three methods are suitability, necessity and fair balance. See section 4.1.2.1 above.

186 Jonathan Griffiths, 'The balancing methodology’ (CIPIL Annual Spring Conference, Cambridge, March 2017).
} 
is important, given the diversity of circumstances as the cases below demonstrate, a degree of flexibility is also necessary for the court to weigh competing interests.

In C-160/15 GS Media v Sanoma Media, ${ }^{187}$ the CJEU took the opportunity to strike a fair balance in interpreting an exclusive right. Here, a third party had made the claimant, Sanoma's copyright content freely available to the public through a hyperlink, without Sanoma's consent. The defendant, GS Media, knowing that it links to infringing content, provided a hyperlink to this link on its own website. The question was whether the GS Media's unauthorised linking amounted to a communication to the public under art 3, Infosoc Directive. ${ }^{188}$ Given the importance of hyperlinking in making access to information efficient, the CJEU was conscious that any interference with it will interfere with the right to information of the internet users under art 11, CFREU. The CJEU observed that recitals 3 and 31, Infosoc Directive require that a fair balance should be struck between the right to property under art 17, CFREU and the right to freedom of expression under art 11, CFREU. ${ }^{189}$ Therefore, the CJEU held that if a person does not know or cannot reasonably know of the infringing nature of the content, and does not seek profit from such hyperlinking, she does not communicate the copyright work to the public. ${ }^{190}$

The CJEU has required fair balancing also when interpreting an L\&E, such as in Deckmyn, where the issue was how parody must be assessed under EU law. ${ }^{191}$ The CJEU relied on recitals 3 and 31, Infosoc Directive, and held that a fair balance must be struck between

\footnotetext{
${ }^{187}$ [2016] WLR(D) 477.

188 ibid [8]-[15], [24].

189 ibid [31].

190 ibid [44]-[47].

191 Deckmyn (n 164) [18].
} 
freedom of expression of the parodist, the rights of the original copyright owner, those of the users and public interest, in defining the appropriate scope of the parody exception in the national legislation. ${ }^{192}$

The CJEU has also required fair balancing among conflicting FRs in granting remedies to counter online copyright infringement. While in Case C-275/06 Promusicae v Telefonica, the issue was whether an ISP could be required to reveal the identity of the infringers, ${ }^{193}$ in Case C-70/10 Scarlet Extended v $S A B A M$, the issue was whether an ISP could be required to place filtering mechanisms to identify and block infringing content. ${ }^{194}$ In Telekabel, the issue was the validity of blocking injunctions issued against the ISPs, ${ }^{195}$ and $M c F a d d n$ addressed measures that a trader providing free $\mathrm{WiFi}$ could be required to take, to prevent online copyright infringement using his network. ${ }^{196}$ In all these cases, the right to protection of intellectual property under art 17(2) of the respective content owners was in conflict with the right to conduct business of the ISPs under art 16 and the right to freedom of information of the internet users under art 11 . The fair balance leaned against the measures that the claimants sought in Promusicae and Scarlet, while categorically stating that the right to property protected under art 17(2) is by no means absolute or inviolable. ${ }^{197}$ In Telekabel, the CJEU outlined the measures that may be taken which will not violate the ISPs rights under art 16 and the user rights under art $11 .{ }^{198}$ In $\mathrm{McF}$ adden, the court held that requiring the trader to protect his

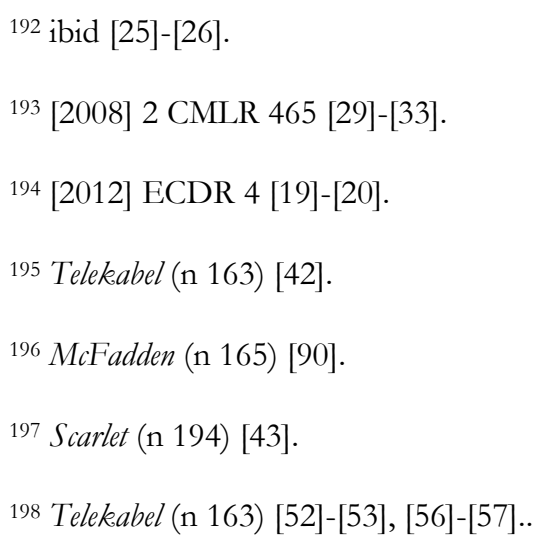


network by a password balanced his rights under art 16 with those of the copyright owners. ${ }^{199}$

Although there is no single methodology that may be gleaned from these cases, the above discussion underscores the flexibility inherent in the act of striking a fair balance.

\subsection{ECtHR and CJEU decisions and the UK Courts}

The concern here is to interpret s 171(3), CDPA in such a way as to imply a policy-based licence, guided by the FR regime. The discussion below addresses applicability and compatibility before the UK courts.

\subsubsection{Applicability}

The question of applicability of either the ECHR or the CFREU to horizontal copyright disputes before the UK courts has not been contentious. The two cases before the UK courts which considered the ECHR through the HRA provisions, namely Ashdown and $H R H$, both proceeded on the assumption that the ECHR is applicable to horizontal disputes. The UK courts have also applied the CFREU rights to horizontal disputes, applying the CJEU decisions. ${ }^{200}$ The more contentious issue has been the compatibility, as discussed below.

\subsubsection{Compatibility}

Section 4.1.2 above reveals that both the ECtHR and CJEU adopt the approach of striking a fair balance among the competing rights, although the ECtHR has in some cases required the least onerous measure to achieve proportionality. These approaches are open to the UK courts to adopt in exercising their powers under s 171(3).

\footnotetext{
${ }^{199}$ McFadden (n 165) [90].

${ }^{200}$ For example, Twentieth Century Fox Film Corporation v BT plc [2011] EWHC 1981 (Ch) [163[-[177].
} 
In $A$ shdown, as discussed in section 3.1.2.3 above, the publication of certain minutes of a confidential meeting authored by the plaintiff had been published with extensive quotations by the defendant newspaper. The issue was whether the right to freedom of expression of the newspaper to report it in public interest under s 171(3) overrode the A1P1 right of the author of the minutes. The High Court followed the ECtHR methodology in first considering whether an FR has been engaged. Having held that art 10, ECHR is engaged, ${ }^{201}$ the court proceeded to consider whether there was an interference with this right. The court observed that it had a margin of appreciation in balancing between A1P1 and art 10, and that the provisions of the CDPA already provide sufficient balance between these rights. ${ }^{202}$ The court held that since the legislature has already struck this balance, one cannot create new exceptions outside the CDPA by reading s $171(3)$ with art $10 .^{203}$

However, the Court of Appeal held that copyright only protects expression and not the information. Therefore, protecting copyright still enables the free circulation of information, except in cases where the expression of the information per se might be relevant. In this sense, the court held that copyright could be antithetical to freedom of expression in some cases. ${ }^{204}$ However, the court insisted that freedom of information should not carry with it the right to make free use of another's work. ${ }^{205}$ In relation to s 171(3), the court held that: ${ }^{206}$

Now that the Human Rights Act 1998 is in force, there is the clearest public interest in giving effect to the right of freedom of expression in those rare cases where this right trumps the rights conferred by the 1988 Act. In such

\footnotetext{
${ }^{201}$ [2001] Ch 685 [12].

202 ibid [13]-[14].

203 ibid [20].

204 [2001] EWCA Civ 1142 [30]-[31], [43].

205 ibid [46].

206 ibid [58]. See also HRH (n 130) [179]-[180].
} 
circumstances, we consider that section 171(3) of the Act permits the defence of public interest to be raised.

Whilst the Court of Appeal's approach was an improvement over the High Court's reading of s 171(3), the above quote seems to suggest that the enforcement of free speech under the HRA is the only situation where s 171(3) could be pressed into service. This is not the case. As the discussion in section 3 (especially section 3.1.3) above demonstrates, s 171(3) can be applied in much more diverse circumstances. Although on the facts s 171(3) was not enforced in Ashdown, it is conceivable that in an appropriate case, a court can interpret s 171(3) in the light of the FR regime in such a way that it creates a policy-based implied bare licence in favour of the users.

Regarding the CJEU decisions, the UK courts have followed the CJEU's rulings in Promusicae, Scarlet and Telekabel while considering the issue of granting injunctions against ISPs to block websites containing infringing content. ${ }^{207}$ However, for the exercise of powers under s 171(3) to imply a policy-based bare licence, cases like Deckmyn and GS Media that refer to recital 3, Infosoc Directive highlighting the importance of public interest in the balancing exercise, would be a valuable support.

\section{Conclusions and Connections}

This Chapter reveals that the UK courts have exercised their common law powers to restrict or deny copyright enforcement, resulting in a policy-based bare licence implied to give effect to certain public interest objectives. Although the courts are not obliged to apply the threestep test while defining the contours of the public interest, the test can serve as a methodological guideline. However, even if the three-step test is not satisfied, the FR regime can support a broader reading of public interest than under the three-step test. In this effort,

\footnotetext{
${ }^{207}$ For example, Twentieth Century Fox (n 200) [163[-[177]; EMI Records Ltd v BSB Ltd [2013] EWHC 379 (Ch)
} [91]-[95]. 
the approach of the ECtHR and the CJEU in striking a fair balance can guide the exercise of the common law powers under s 171(3) by the UK courts.

The courts' powers to enforce public interest from an open-ended list will be useful in permitting certain basic functionalities on the internet, especially when the copyright content is placed without the consent of the copyright owner, which leads us to Chapter VIII below.

\footnotetext{
q000
} 


\section{Implied Licences and the Internet}

This Chapter tests and illustrates the analyses of implied licence in the foregoing Chapters, in relation to the internet, and in particular, the three basic functions at the heart of the internet's technological prowess, namely: browsing, hyperlinking and indexing. These functions benefit not only internet users, but also the copyright owners who can make their works available to an unprecedented number of recipients. Although these functions are in themselves beneficial, the underlying technological processes infringe exclusive rights. To deny any of these functions by asserting exclusive rights reduces the benefits of the internet. One way to permit these functions is to explore if the exclusive rights these processes engage can be impliedly licensed. The scope of such implied licence should be no more than permitting each of these functions.

Let me begin by explaining each of these functions, and how each relates to the exclusive rights. Regarding browsing, the internet is a repository of enormous amounts of information. Users of the internet must be able to benefit from this vast resource by viewing or 'browsing' it on their computer monitors. When a user looks up a webpage, several temporary copies are made while obtaining the content of the webpage from its server, and on the user's monitor. ${ }^{1}$ Even if the user does not download the content, copies are made within the viewer's computer temporarily for easy access to the pages in future and to reduce network traffic, which are called cached copies. ${ }^{2}$ Cached copies may be deleted by the user or, automatically after some time, depending on the configuration of the relevant computer. ${ }^{3}$ If the copies made due to browsing and caching all need permission from the content owner,

\footnotetext{
${ }^{1}$ Lisa Anne Katz Jones, 'Is Viewing a Web Page Copyright Infringement?’ (1998) 4 Appeal 60-71, para 2.

2 Richard S Vermut, 'File Caching on the Internet: Technological Infringement or Safeguard for Efficient Network Operation?' [1997] 4 J Intell Prop L 273, 296.

3 Public Relations Consultants Association Limited v The Newspaper Licensing Agency Limited [2013] UKSC 18 [2].
} 
then it would significantly impede the functioning of the internet. If browsing is not authorised, it would make infringers out of millions of users for simply viewing websites. ${ }^{4}$

Regarding hyperlinking, the internet infrastructure enables a person to 'hyperlink' directly to the web page containing the required information, skipping the step of having to remember or type the website address, making the accessibility of information more efficient. ${ }^{5}$ Given the enormity of the content on the internet, the ready accessibility and crossconnections enhance the value of the internet exponentially. Linking need not be to the home page of the website being linked to, but to any of the internal pages (deep linking). Linking can also take place in such a way that when clicked, it opens being surrounded or framed by another webpage (framing). If linking amounts to communication to the public requiring the consent of the copyright owner, each time a person wishes to link to a website, the consent of the copyright owner must be obtained. This dramatically reduces the efficiency of the internet.

Regarding indexing, the growth of the content on the internet is made possible by applications facilitating free and ready searches to access relevant information. Without such applications, the labyrinth of information on the internet could become inaccessible if the exact address of the page is unknown. Search applications crawl websites, scrape their data, and prepare an index of every word that appears on the website. This helps create searchable databases, where the use of a search term in the search tab reveals all websites that contain that term. In some cases, the technology also allows for making a cached copy, which the search provider can display if the main website is unavailable. Each of these functions creates copies of the copyright works, and makes the search results available as hyperlinks. If the search provider must seek permission from the copyright owner each time it crawls a

\footnotetext{
${ }^{4}$ ibid [36].

${ }^{5}$ Graham Smith, et al, Internet Law and Regulation (Sweet \& Maxwell 2007) 1.
} 
website, indexes, or makes the results available, the efficacy of the internet could be dramatically reduced.

Copyright works on the internet may have been placed by the copyright owner herself or with her consent on one hand, or without her consent on the other. The former might signal the copyright owner's consent to benefit from the advantages of the internet, namely browsing, hyperlinking and indexing, depending on whether she uses any terms of use for such content, and their scope. The framework for consent-based implied licences discussed in Chapters III and IV above may be applied to these situations. If the knowledge of the copyright owner as to the technology involved must be imputed, then the framework in custom-based implied licence may be applied. However, sometimes a copyright owner might impose terms of use which might deny even the most basic functions on the internet. This might require the framework for policy-based implied licences in Chapter VI, to be applied. All these possibilities are explored in section 1.

A copyright owner might choose to place her content on the internet, but behind a paywall. The impact of doing so on implied licences, if any, is discussed in section 2.

When content is placed on the internet without the copyright owner's consent, the framework discussed in Chapter VII on policy-based implied bare licences may apply. This is discussed in section 3 .

The Chapter concludes with section 4 underscoring the need to transpose the implied licence doctrine from the analogue world to the online world.

\section{Content Placed by Copyright Owner or with her Consent}

This section examines the impact of copyright content being placed on the internet by the copyright owner or with her consent, on the possibility of implying a licence to permit browsing, hyperlinking and indexing. A copyright owner placing her content on the internet 
or consenting for someone else to do so, is a voluntary act. Therefore, the following paragraphs first explore whether a consent-based licence can be implied. Chapter II demonstrated that to imply a consent-based licence (bare or contractual), one needs to show a positive act, a neutral act, and the circumstances within the knowledge of the copyright owner. ${ }^{6}$ We shall see below how these are identified in the internet context.

If knowledge of the copyright owner as to any of these functions is incomplete, and it makes more sense to impute such knowledge, then a custom-based licence may be implied. ${ }^{7}$ And if it is more appropriate to attribute the implication to a policy than to the copyright owner's consent, then a policy-based licence must be implied. ${ }^{8}$

\subsection{Positive Act}

A mere placing of the content on the internet could potentially become the first step towards implying a licence. An analogy can be drawn with the physical world to explain this. ${ }^{9}$ Suppose $\mathrm{P}$, an artist, creates a pamphlet regarding her upcoming art exhibition, incorporating certain photographs she has taken of her art. She places copies of the pamphlet on a display stand dedicated for promoting upcoming events at her city's major public performance venue. $\mathrm{P}$ knows the consequences of leaving copies of her pamphlet on the stand to be that people will pick up a copy for information. By her act of placing these pamphlets on the stand, she has

\footnotetext{
${ }^{6}$ Chapter II, section 3.1.1 above.

${ }^{7}$ Chapter II, section 3.2.1 above.

${ }^{8}$ Chapter II, section 3.3.2 above.

${ }^{9}$ In drawing a parallel between analogue and digital environments, I agree with 'prescriptive parallelism', which conveys the notion that the traditional copyright balance of rights and exceptions should be preserved in the digital environment. Conceptualised by Jerome Reichmant, Graeme Dinwoodie and Pamela Samuelson, 'A reverse notice and takedown regime to enable public interest uses of technologically protected copyrighted works' [2007] 22 Berkeley TechLJ 981, 1042.
} 
performed the positive act that could potentially lead to implying her consent for the pamphlet to be used in some way (subject to other circumstances discussed below). ${ }^{10}$

The display stand in the public place can be likened to the internet as a platform. The content on the printed pamphlets can likewise exist on a website. Just as people come to this stand to pick up pamphlets, people visit websites for similar purpose. It is in the very location of the stand that it is publicly accessible. Likewise, it is in the very nature of the internet that it is publicly accessible. Whoever places content on this stand knows its public nature, just as whoever places content on the internet knows its public nature. Just as placing a pamphlet signals a possible consent for the pamphlet to be used in some way, placing content on the internet signals a possible consent for such content to be used in some way.

Copyright owners placing their content on the internet can be of different levels of sophistication - starting from a person writing a short piece on social media or a blog, to a person having a website custom-built to showcase her work or promote a business. Content placed on social media or a blogging platform will normally be subject to the terms and conditions of the platform, but an implied licence might still exist in favour of the public. In most other cases, copyright owner places her content on the internet with the help of web designers familiar with building a webpage. This has an impact on their knowledge of the technology, as discussed in section 1.3 below.

The copyright owner placing or consenting to place her content on the internet does not mean that there is an implied licence to use the content in every manner possible. Due to the free accessibility of information on the internet, the internet users may believe that all the

\footnotetext{
${ }^{10}$ At this stage, the only point that this example seeks to makeis that the placing of the pamphlet in a place where a person can freely pick up a copy, conveys the beginning of an implied licence. It is possible that person picking up a copy of the pamphlet can then do whatever she pleases with the pamphlet. Since this is not within the knowledge or contemplation of the copyright owner, it does not make it an implied gift. See Chapter II, section 3.1.1.3 above for the conceptual basis of an implied gift and discussion below on copyright owner's knowledge.
} 
content available on the internet is free for whatever use they wish to make of it. Further, lay persons may wish to believe that by placing copyright content on the internet, the copyright owner has relinquished her rights. In legal terms, this must mean the content owner assigning her rights away to the community of internet users by simply placing her content on the internet. ${ }^{11}$ Although it is technologically possible for the users to use the content on the internet in whatever manner they please, and it is very difficult for the content owners to police such uses, there is still no basis for the assertion that the content on the internet is free for all.

Robin Ray v Classic FM states that where a licence would suffice, only a licence should be implied, and not an assignment, and that a minimalist approach should be adopted. ${ }^{12}$ Although this principle was originally applied in the context of a contractual licence, it has a more universal application, as evidenced in the cases discussed in Chapter III. Giving lyrics of a song in Banksv CBS Songs Ltd, ${ }^{13}$ or the draft opening script in Brighton v Jones, ${ }^{14}$ were all treated as giving rise to an implied licence, and not as an implied gift. Although in these cases, the there was an identifiable person as a licensee, in case of the internet, instead of a specific person, the community of internet users who access the work become licensees. In principle, nothing stops a copyright owner from granting a licence in favour of a community of users, as opposed to an identifiable user. Therefore, the mere act of placing content on the internet

\footnotetext{
11 One may argue that a copyright owner placing her content on the internet amounts to an abandonment of copyright simply because there is no specifically identifiable recipient. However, abandonment is a highly controversial area in property law. It is generally accepted that a property owner must intend to relinquish all ownership rights over the property to be able to abandon it. See Kevin Gray and Susan Francis Gray, Elements of Land Law (5 $5^{\text {th }}$ edn, OUP 2009) para 1.2.78. It is difficult to infer an intention to relinquish all rights to the copyright work by the copyright owner simply placing the work on the internet.

12 [1998] EWHC Patents 333.

13 [1996] EMLR 440.

14 [2004] EWHC 1157 (Ch).
} 
does not amount to anything more than pointing to a possibility of implying a licence, depending on the existence of the other factors.

\subsection{Neutral Act}

The positive act of placing content on the internet must be coupled with the inaction of leaving the content there. There are two possible ways of leaving the content on the internet.

- Firstly, the copyright owner does not place any terms of use for the works she places on the internet. This means she does not interfere with the use of these works on the internet. The consequences of the positive act must therefore, ensue unrestricted, making the neutral act absolute.

- Secondly, the copyright owner does place terms of use for the works she places on the internet. Depending on the terms, the copyright owner interferes with some or all uses of these works, permitting only those consequences of the positive act that the terms indicate. This makes the neutral act partial. Sometimes, a partial neutral act can also be conditional on proving some consideration.

Neither the positive act, not the neutral act can occur in vacuum. They must be accompanied by the knowledge of the copyright owner as to the circumstances, as discussed below.

\subsection{Knowledge of the Copyright Owner}

The copyright owner's knowledge of the circumstances must include the possibility of the internet users freely viewing or reading (browsing), linking (hyperlinking), and indexing copyright content on the internet. When there are no terms of use attached to content placed on the internet, the knowledge of the copyright owner differs from when there are terms of use incorporated. Further, the knowledge of the technological process may or may not be fully articulated, and in certain circumstances, the knowledge must be imputed. Accordingly, the extent of knowledge determines whether a consent-based, a custom-based or a policy-based 
licence will be implied. The following paragraphs assess the knowledge of the copyright owner when the neutral act takes place firstly, without terms of use, and secondly, with the terms of use being placed on the webpage.

\subsubsection{No terms of use incorporated}

Although copyright owners are becoming savvy about incorporating terms of use in relation to the content they place on the internet, there is still a sizeable amount on the internet that is unaccompanied by any terms of use. In the absence of the terms of use, any licence implied will be a bare licence. Therefore, the components of the knowledge of the copyright owner will include the realisation of authorship, the realisation of the gratuitous nature of her actions and the knowledge of the circumstances, as set forth in Chapter III above. ${ }^{15}$

The absence of the terms of use might be because the copyright owner does not realise that her work attracts copyright protection. As discussed in Chapter III, this component of the knowledge must be assessed, even if a court sets a low threshold for its assessment. ${ }^{16}$ The conduct of not incorporating any terms of use, nor a paywall conveys that the copyright owner is aware that there is no bargain and no consideration that flows back to her. ${ }^{17}$ This leaves us with the last component, namely the knowledge of the circumstances. Placing no terms of use still does not mean unrestricted use of copyright works. The scope of the licence is determined by the actions that are reasonably within the copyright owner's knowledge.

Revisiting the example where $\mathrm{P}$ had placed her art exhibition pamphlets on the public stand, there is a limit to the uses that a member of the public, Q, can make of the copy she

\footnotetext{
${ }^{15}$ See Chapter III, sections $1.3 .1,1.3 .2$ and 1.3 .3 respectively.

${ }^{16}$ See Chapter III, section 1.3.1.2.

${ }^{17}$ See Chapter III, section 1.3.2.
} 
takes. It will be within P's reasonable knowledge that Q may read her copy and pass it on to someone else. It will not be within P's reasonable knowledge or expectation that Q will make copies of it, or make a derivative work of it, although as a practical matter it is possible for $\mathrm{Q}$ to do so. Likewise, on the internet, although it is practically possible for an internet user to do whatever she pleases with the content on the internet, within a copyright owner's reasonable knowledge or contemplation might only be extend to the content being browsed, hyperlinked and indexed. The knowledge of the copyright owner in relation to these actions must be assessed to the extent that these functions engage the exclusive rights of reproduction and communication to the public.

\subsubsection{Browsing}

Browsing is simply the act of viewing webpages online. In our example above, $\mathrm{P}$ not only knows that the members of the public will see the pamphlet, it is indeed the objective she wants to achieve. Likewise, one of the most obvious consequences of placing or consenting to place one's work on the internet is that it can be viewed by millions of users. In many cases, this may not only be within the copyright owner's knowledge, but indeed her objective. This may be reinforced by her conduct of incorporating no terms of use for her content.

As far as the user is concerned, she is only viewing the contents of the web page. However, the technology behind generates many copies in the process - on-screen and in the computer's cache, thereby engaging the right of reproduction, although the copies are only temporary. Thus, for a consent-based licence to be implied, the copyright owner must have the knowledge of the on-screen copies and the cached copies generated by browsing.

Since the inception of the internet scholars have written about whether these temporary copies made either during transmission, display or in the computer's cache, infringe 
the reproduction right; and if they do, whether such reproduction can be impliedly licensed. ${ }^{18}$ The knowledge of the on-screen copies as being the product of viewing the website, is the easiest to establish. Given the length of time internet has been in existence and the increasingly indispensable role internet plays in peoples' lives, it is more likely than not that the copyright owners are aware of the cached copies generated during browsing. If it can be shown that the copyright owner had the actual knowledge of the on-screen and cached copies being created, a consent-based bare licence can be implied to permit browsing.

However, EU law has chosen to take the L\&E route, rather than the implied licence route. Article 5(1), Infosoc Directive embodies an exception to the right of reproduction, permitting temporary copies created due to the functioning of the internet and other new technologies. ${ }^{19}$ The requirements of this exception as paraphrased in Case C-5/08 Infopaq International $A / S \vee$ Danske Dagblades Forening, ${ }^{20}$ by the CJEU are: the copies are temporary, transient or incidental; the process is an integral and essential part of a technological process; the sole purpose of that process is to enable a transmission in a network between third parties by an intermediary or a lawful use of a work; and the copies have no independent economic significance. Can the on-screen and cached copies be brought within this exception?

Some had argued that it may be possible to use a combination of implied licence and the temporary copying exception. ${ }^{21}$ To the extent that the copyright owner knows of the onscreen copies created due to the users viewing her website, there is a consent-based implied bare licence; to the extent that such viewing generates cached copies, such reproduction is

\footnotetext{
18 Jones (n 1) para [8]; Vermut (n 2) 315-327.

19 Transposed into CDPA, s 28A.

20 [2009] ECR I-6569 [54].

${ }^{21}$ Smith (n 5) 23-25.
} 
covered by the temporary copying exception. The concern was that since cached copies are generated due to the volition of the person browsing, whether they were an integral part of the technological process.

However, the CJEU held in Case C-360/13 Public Relations Consultants Association v Newspaper Licensing Agency that all copies created during browsing are covered under art 5(1), Infosoc Directive, ${ }^{22}$ without relying on implied licence. The Court's reasoning is discussed in section 2.3.2 below, since the websites under consideration incorporated terms of use. Since the court's decision brought browsing under an L\&E and not an implied licence, the decision applies equally where the websites do not incorporate terms of use.

Thus, where there are no terms of use incorporated on a website, browsing could be authorised by a consent-based implied bare licence. However, the CJEU has brought browsing under an L\&E. This has taken away the flexibility of that the doctrine of implied licence offers, as discussed further in section 1.3.2 below.

\subsubsection{Hyperlinking}

The internet infrastructure is such that once the content is on the internet, a link can be established to reach exactly the same location, without having to type its address. Hyperlinking involves providing the address of a webpage, as opposed to the webpage itself. Until the link is clicked, no copies of the page are created. Once clicked, the linked page is summoned from its hosting server to the user's monitor. Does this amount to communication to the public?

While it is clear that browsing engages the right of reproduction, it is controversial whether hyperlinking engages the right of making available to the public. Therefore, the first

\footnotetext{
22 [2014] ECDR 22 [63].
} 
task is to establish that hyperlinking does engage the right of communication to the public, which includes the right of making available under art 3(1), Infosoc Directive. ${ }^{23}$

Some scholars argue that a communication must involve transmission, and hyperlinking does not involve such transmission; and even if it does, such transmission is not of a 'work' as required under art 3(1), Infosoc Directive. ${ }^{24}$ Although providing the link alone does not involve transmission, once clicked, there is transmission of the digital bits of the work in bringing the webpage on the user's monitor. The only purpose of a link is so that it may be clicked, thereby encompassing transmission in the overall functioning of hyperlinks. Further, even if a link is not a copyright work in itself, it has the ability to make the work hosted at a server available to the public. Therefore, the link being merely an address does not deprive it of the ability to communicate. As such, in principle, hyperlinking is technologically capable of communicating a work to the public.

One may further argue that hyperlinks only provide a facility for communicating a work to the public, which is insufficient as an intervention to amount to communication to the public. In $S G A E$, the CJEU held that the mere provision of TV sets in hotel rooms does not amount to communication to the public; however, using such TV sets if signals are transmitted to hotel rooms, then it amounts to communication to the public. By analogy, if a person only provided the address of a webpage to be copied in the browser, then it would be a mere facility. However, a hyperlink is an active link, the mere clicking of which takes the user to the relevant page.

\footnotetext{
${ }^{23}$ Case C-306/05 SGAE v Rafael Hoteles SL [2006] ECR I-11519 [43].

${ }^{24}$ European Copyright Society: The Reference to the CJEU in Case C-466/12 Svensson, Paper No 6/2013, February 2013, para 6, <http://ssrn.com/abstract=2220326> accessed 1 February 2017.
} 
Framing and deep-linking are technologically the same as linking in that the page linked to is summoned when clicked. In framing, the link appears being surrounded by other content. The overall impression of the website within which the link is framed might mislead the public or pass off goods or services, attracting liability in unfair competition. Likewise, deep-linking skips the home page which may deprive a copyright owner of advertising revenue. However, these will not present copyright issues different from those for hyperlinking. Therefore, the arguments in relation to hyperlinking also generally hold good for framing and deep-linking.

Hyperlinking, therefore, does engage the communication right. Although hyperlinks only point to works that have already been communicated, art 3(3), Infosoc Directive says that the communication right 'shall not be exhausted.' On the internet, this could mean that the owner placing her content on the internet does not exhaust the making available right; every subsequent making available which any member of the public engages in must still be authorised by the content owner. If a statute provides for the exhaustion of a right, for the reasons explained in Chapter VI in relation to exhaustion of distribution right, ${ }^{25}$ there is no reason to use implied licence. Since communication right does not exhaust, there are good reasons to use implied licence. Within the framework being discussed here, whether a further communication is authorised by way of linking depends on the knowledge of the copyright owner as to the possibility of the internet users linking to her work.

Going back to the example of P's pamphlets on the public shelves, suppose the pamphlet did not include any terms governing its use. Suppose further that the managers of the public venue decide to provide on a notice board at the entrance of the public venue the title of P's event, date and venue, directing the public to find more information on the pamphlets available on the shelves. Suppose also that such notice is surrounded by other

\footnotetext{
25 See Chapter VI, section 2.2 above.
} 
information such as other events etc (i.e., framed by other content). P's placing of the pamphlets on the shelf was with the objective that any member of the public who comes into the venue will see it. The venue managers doing more to expose the information on the event to those who visit the venue will still be within the copyright owner's knowledge, as her objective is to maximise the exposure. It will not matter if the notice is provided as a standalone information or being surrounded by other information.

A similar logic applies to linking, with the entry on the notice board being likened to a link and the pamphlet to a webpage. The content originally placed on the internet with the copyright owner's consent is potentially open to any user of the internet. Placing no terms of use conveys that the copyright owner wishes to take advantage of all benefits of the internet as a public platform. Since this objective is achieved by providing the link, it can be regarded as being within the copyright owner's knowledge. It will not make a difference if the link is provided on its own or is surrounded or framed by a third party's content. It will also not matter if the link is to a page deeper on her website skipping the home page, since all pages are equally exposed to the public. Thus, a person linking, framing or deep-linking to content placed on the internet with the copyright owner's consent and without any terms of use, benefits from a licence to communicate the work to the public by linking, implied based on the copyright owner's consent.

To the extent that I argue linking is a matter of implied licence, my views may seem similar to those of Association Litteraire et Artistique Internationale (ALAI) in their Report and Opinion on Svensson. ${ }^{26}$ However, my conception of the bases for implying a licence goes beyond the consent of the copyright owner. Therefore, if for any reason, the knowledge of

\footnotetext{
${ }^{26}$ ALAI 15 September 2013, Report on the making available and communication to the public in the internet environment - focus on linking techniques on the internet, <http://www.alai.org/en/assets/files/resolutions/ making-available-right-report-opinion.pdf $>$ accessed 16 February 2017.
} 
the copyright owner as to the possibility of internet users hyperlinking to her content cannot be established, then one can explore if such knowledge can be imputed to her. For such imputation, hyperlinking should be established as a custom.

Some commentators believe that there are numerous practices that have emerged in the online world that can be regarded as internet customs. ${ }^{27}$ However, the threshold for a practice to become a custom under the UK law is very high, as discussed in Chapter $\mathrm{V}$ above. ${ }^{28}$ One may argue that the internet is too large an environment to be regarded as a location, and its users too disparate to be regarded a community. However, the internet as a location does have distinct characteristics, and the actions that the users engage in on the internet are consistent. As such, it is conceivable for some practices to have become customs, since the formation of a custom does not require affirmation by a court. ${ }^{29}$

Polanski argues that linking without authorisation is an internet custom, ${ }^{30}$ although he does not adopt the criteria of the UK courts to establish this. However, if one were to apply the main criteria: linking as a practice is consistent, and therefore 'certain'; it is 'notorious' given its widespread use; it is not only 'reasonable', but it achieves the objective for which the world wide web exists; it is not contrary to any law because copyright owner's content is already on the internet with her consent; one may argue that the practice is recognised as binding because it enhances the efficacy of the internet. Regarding the refined criteria, ${ }^{31}$ the internet community is representative of the copyright owner, since she has herself placed or consented

\footnotetext{
${ }_{27}$ Paul Polański, Customary law of the internet: in the search for a supranational cyberspace law (University of Melbourne, 2007) 305 (based on the author's thesis).

28 See Chapter V, sections 1.1 and 1.2.

${ }^{29}$ Cunliffe-Owen v Teacher and Greenwood [1967] 1 WLR 1421, 1438.

${ }^{30}$ Polanski (n 27) 307-11.

${ }^{31}$ See Chapter V, section 2.1.2.
} 
to place her work on the internet. The motivation of linking is to enhance the efficacy of the internet, and not mere convenience. Given the objectives that hyperlinking achieves on the internet, its impact can be regarded balanced and therefore, linking also answers the refined criteria. Thus, once the custom is established, it is possible to imply a bare licence based on it to enable internet users to hyperlink to the content on the internet.

However, in Case C-466/12 Svensson v Retriever Sverige $A B,{ }^{32}$ the CJEU adopted a different approach. In this case, the applicants were journalists who wrote articles in a certain newspaper. The defendants operated a website that provided a list of clickable links to articles published by other websites. It was common ground that these articles were freely accessible on their website. ${ }^{33}$ The decision does not state specifically that these websites did not carry any terms of use. The assumption in this part is that the websites did not. If the websites did carry terms of use, the discussion in section 1.3.2.2 below applies. The question was whether linking amounts to communication to the public, requiring the copyright owner's consent before one could link. ${ }^{34}$ And whether it made any difference if the act of linking amounted to framing. ${ }^{35}$

The CJEU held that a clickable link makes copyright works available to the public at a time and from a place chosen by them, and therefore is an act of communication to the public. ${ }^{36}$ However, in order to be regarded as communication under art 3(1), Infosoc Directive, the communication of the works using the same technical means must be to a 'new public'. The content which was linked was in any event freely available to the users, as there were no

\footnotetext{
32 [2014] ECDR 9.

33 ibid [8].

34 ibid [14].

35 ibid [13(3)].

36 ibid [19]-[20].
} 
restrictions for its access. Since a clickable link only provided direct access to the content to which the same public already had access, the CJEU held that this did not amount to a communication to a 'new public'. As such, the CJEU held that there was no need for the act of linking to freely available content to be authorised by the content owners. ${ }^{37}$ The CJEU further held that a new public comes into existence when the hyperlink makes it possible for users to access works by circumventing restrictions, because such public was not within the copyright owner's contemplation during the original authorisation. ${ }^{38}$ The CJEU also held that their decision does not alter if the link was provided as a frame. ${ }^{39}$

The CJEU's decision hinged on 'new public' - since hyperlinks do not communicate works to new public, no authorisation of the copyright owner is necessary. There are two limitations with the concept of new public. Firstly, the concept of new public only addresses who is authorised to communicate, and not how they are authorised to communicate. The concept assumes that so long as it is the same public to whom the copyright owner directed her original communication, it does not matter how such public further communicates. This may be true if there are no terms of use. But this reasoning breaks down if there are terms of use, which say for example, that the works cannot be used for commercial purposes. In such a case, the issue is not to whom they are authorised to communicate, but how they can communicate - namely, only for non-commercial purposes. People engaging in commercial use of the work may be the same public to whom the original communication was available, but they are still not authorised to communicate the works for commercial purposes. In such cases, the CJEU's binary definition of whether a public is new does not assist. The implied

\footnotetext{
37 ibid [25]-[28].

38 ibid [31].

39 ibid [30].
} 
licence approach, on the other hand, can accommodate this additional nuance, as discussed in section 1.3.2.2 below.

Secondly, the concept of new public hinges on 'access' to the works on the internet. ${ }^{40}$ If the works linked to are freely accessible, then there is no new public with linking. If the works are not freely accessible, i.e., behind a paywall, then there is new public if the link circumvents such access restrictions. If a person $\mathrm{P}$, breaks the paywall and places the content on the internet, to a subsequent user on the internet, say $\mathrm{Q}$, such content is then freely available, as Q can access it without restrictions. With the access definition of new public, Q will not be a new public, and her linking to the freely accessible (infringing) content will still not amount to communication to the public. ${ }^{41}$ This is an unsatisfactory result, especially if Q knows of the infringing nature of the content and still goes ahead to communicate to the public. The CJEU's simplistic and binary approach to how a new public comes into existence will not work if there is linking to infringing content. Again, implied licence is a better approach, as discussed in section 3.2 below.

Thus, where no terms of use are incorporated, hyperlinking could be authorised by a consent-based or a custom based implied licence. Although the CJEU has held hyperlinking to content freely available on the internet to be not covered by communication to the public, this interpretation is problematic, making the implied licence route still relevant and necessary.

\subsubsection{Indexing}

Indexing by a search application involves crawling a website using a software, scraping it by copying to extract relevant words, and indexing the relevant words. This engages the right of

\footnotetext{
40 ibid [31].

${ }^{41}$ See Case C-160/15 GS Media BV v Sanoma Media Netherlands BV, ECLI:EU:C:2016:221, Opinion of AG Wathelet, paras [68]-[74].
} 
reproduction. The results of a search are normally delivered as a list of hyperlinks to the specific webpages matching the search criteria. Linking, as discussed above, engages the communication right. To imply a consent-based licence enabling indexing, one must show that the actions involved in indexing are within the copyright owner's knowledge, to the extent that such processes engage exclusive rights.

A person uploading to social media cannot be regarded as having the same knowledge as a person having her website built by expert web designers. However, a person posting on third party platforms such as social media cannot complain of their work being scraped and indexed, because they are taken to know of and intend to reach the vast audience to whom the platforms are exposed. Control over indexing is left to the managers of the social media platform, with users being permitted to handle their own privacy settings. ${ }^{42}$ Those who design their own websites or have them designed, are likely to know that search engines do crawl their websites, scrape and index them, given the ubiquity of the use of search engines.

Crawling, scraping and indexing are all processes automated with the use of a software. Given the impossibility of individually seeking consent from each website owner to scrape, there are widely recognised and well publicised industry standards which allow website owners to let the crawling software know whether they consent for their webpages to be scraped. Such expression of consent can take the form of meta-tags within the software code of the website, which the search applications are equipped to read and follow. ${ }^{43}$ Alternatively, the insertion of a 'robots.txt' file on their website with an indication of 'allow' or 'disallow' can also instruct the crawling software whether the website can be scraped. A robots.txt file set to disallow

\footnotetext{
${ }^{42}$ See for example, <https://www.facebook.com/about/basics/> accessed 22 December 2016.

43 <https://developers.google.com/webmasters/control-crawl-index/docs/robots_meta_tag> accessed 14 February 2017; see also Field v Google 412 F Supp 2d 1106, 1112-3.
} 
results in such website or its cached copy not being shown in the search results. ${ }^{44} \mathrm{I}$ call these technological measures the 'code'. The search providers follow the instructions of the code more as a matter of social norm, than as a legal duty. ${ }^{45}$ If the code is not used in designing a website at all, the crawling software still goes ahead to index the website. ${ }^{46}$

Therefore, in addition to knowing the possibility of their websites being indexed, copyright owners must also know of their ability to put in place the codes to convey whether indexing is permitted. If a copyright owner uses the code in the design of the website, then this must convey her knowledge of both the possibility of indexing taking place and of the code which enables her to signal to the crawling software. If she then, sets the code to allow indexing, she cannot then say that she was unaware of the functionality of the code. A copyright owner having her website built is more likely to be aware through her web designers, of the use of the code.

Search results are delivered in the form of hyperlinks. However, if scraping as the first act can be controlled by the code, the subsequent action of indexing will not take place. If a webpage is not in the search engine's index, it will not be hyperlinked in the search results. Therefore, the same code settings can be used as a response to both indexing and the consequent hyperlinking.

Thus, if the knowledge of the copyright owner as to her website being indexed and the use of the code to control it can be established, then a consent-based licence can be implied

\footnotetext{
44 <https://support.google.com/webmasters/answer/79812?hl=en> accessed 14 February 2017; Field (n 43) 1113.

45 Monika Isia Jasiewicz 'Copyright Protection in an Opt-Out World: Implied License Doctrine and News Aggregators’ [2012] 122 Yale LJ 837, 844, 848.

46 <https://support.google.com/webmasters/answer/6065802?hl=en\&ref_topic=6065797> accessed 28
} February 2017. 
to permit indexing, and consequent hyperlinking.

If a copyright owner does not use the code at all, it may well be because she does not know of the existence of the code. The lack of such knowledge negates consent, and the implied licence based on it. Under those circumstances, one may explore if such knowledge can be imputed to the copyright owner. For this, one may explore if it is possible to establish a custom recognising the practice of using the code to instruct crawling software.

For the code settings as a practice to have become a custom in the UK, it must be assessed applying the main criteria for establishing a custom. ${ }^{47}$ The practice of placing the code is consistent, and therefore, 'certain'. Search engines like Google publicise on their website the function of the code. ${ }^{48}$ These are also widely known to the web designers who are most likely employed when a copyright owner wishes to place her content on the internet. Therefore, notoriety is likely to be established. It is also 'reasonable' because it makes the automated process of scraping more responsive to the instructions of the copyright owner. It is not against the law, but indeed, its incorporation could help avert infringement. A consistent use of the code by the copyright owners can make the practice of using the code binding.

Regarding the refined criteria identified in Chapter $\mathrm{V}$ above, ${ }^{49}$ the practice of using the code is motivated by enhancing the technological efficacy of indexing, which is essential for organising and accessing the enormous content on the internet. The practice is not burdensome to copyright owners, and hence its impact is balanced. Since the content on the internet is placed by the copyright owner or with her consent, the internet community is

\footnotetext{
${ }^{47}$ See Chapter V, section 1.1 above.

48 See generally, <https://support.google.com/webmasters/answer/6062608?hl=en> and <https://support.google. com/webmasters/answer/79812?hl=en> both accessed 21 December 2016.

49 See Chapter V, section 2.1.2 above.
} 
representative of her. Thus, it may be possible to establish that the practice of placing the code within the web design is a custom. If the custom is established, ${ }^{50}$ it will be possible to impute its knowledge to those copyright owners who do not place any code on their websites. It will then be possible to imply a licence based on such custom to permit indexing of such websites.

A good example is the US case of Field $v$ Google Inc, ${ }^{51}$ which implied a consent-based licence. Here, the claimant, Field, an author, had placed his poems on his personal website. Field not only knew of the code, but had set it to allow indexing. The decision speaks of no terms of use in relation to the website. ${ }^{52}$ Field claimed that the defendant, Google Inc, was liable for copyright infringement for copying and distributing his work. ${ }^{53}$ Google stated that in view of the enormity of the content on the internet Google uses an automated means called the Googlebot, to crawl across the internet, and index webpages. As part of this process, Google makes a copy of each web page and stored it temporarily as 'cache' for archival purposes. ${ }^{54}$ When a user searches a term on Google's search engine, the results include a hyperlink with the title of the webpage incorporating its address, so that when clicked, it takes the user to the webpage concerned. ${ }^{55}$

In his evidence, Field admitted that he had set the code to 'allow' search engines to scrape his website. ${ }^{56}$ Despite this, when his website was scraped, indexed and cached, he sued

\footnotetext{
${ }^{50}$ A welcome side effect of this will be that the instructions of the code will be binding on the crawling software, as opposed to being only a social norm. See Jasiewicz (n 45) 844, 848.

51412 F Supp 2d 1106.

52 ibid 1114.

53 ibid 1110.

54 ibid 1110-12.

55 ibid 1111.

56 ibid 1113-4.
} 
Google for copyright infringement. The court held that Field knew that Google would interpret Field's website code settings as a permission to scrape his website. ${ }^{57}$ By this, the court concluded that Field had impliedly licensed Google to scrape, cache and index his website. Rationalised within the framework for a consent-based implied licence, Field placing his content on the internet, standing back when Google indexed it, knowing that he could set the code to disallow such indexing implies a licence.

Conveniently in Field, Field admitted to actual knowledge of the function of the code, and had indeed used it to allow indexing. If Field did not have the knowledge of the code at all, then the court could have explored the custom based implication. Some US commentators suggest that the practice of placing the code on the websites may have become a custom, given that the court in Field regarded it to be a widely-recognised and well publicised practice. ${ }^{58}$

Thus, indexing can be authorised by implying a consent-based licence or a custombased licence.

\subsubsection{Incorporating terms of use}

Section 1.3.1 above considered whether browsing, hyperlinking and indexing were authorised by a consent-based or a custom-based implied licence, when the websites incorporated no terms of use. This part examines where terms of use are incorporated, which is increasingly common in recent times. These terms of use normally concern not only the use of copyright works such as text, images and software, but also the use of the website as a whole, including the use of any trademarks. ${ }^{59}$ Although in most cases the website terms of use amount to an

\footnotetext{
57 ibid 1116.

58 John Seiman, 'Using the Implied Licence to Inject Common Sense into Digital Copyright', [2007] 85 NCL Rev 885, 915-6.

${ }^{59}$ For example, the terms of use of Gucci is in relation to 'photographs, images, illustrations, text, video clips, audio clips, designs, logos, trademarks, trade dress and other materials' and 'the software used in the design and
} 
express bare licence, in some cases they may amount to a contract. For example, the terms of use of a website providing information, such as London Stock Exchange, are more likely to amount to a bare licence. ${ }^{60}$ The terms of use of an interactive website on the other hand, such as a newspaper providing for readers' contributions, ${ }^{61}$ or a social media platform, ${ }^{62}$ may amount to a contract. In the latter case, in return for the users providing their content, the website operator provides a web-platform.

The discussion below proceeds on the basis that the website terms of use can either be express bare licences or contractual licences. For a consent-based implied bare licence, as noted in Chapter III, the components of the knowledge of the copyright owner consist of the awareness of copyright entitlement, the gratuitous nature of the licence, and the surrounding circumstances. ${ }^{63}$ The existence of the first two components is uncontroversial with express bare licences. The knowledge of the circumstances will require the knowledge of the terms of use and other surrounding circumstances. If the website terms of use amount to a contractual licence, the discussion here is only of what I called the licence stage, and not of the contract stage. ${ }^{64}$ The components of knowledge to be considered if the terms of use amount to a

development' of the website. < http://www.gucci.com/uk/assistance/copyright_information>, accessed 14 May 2015.

\footnotetext{
${ }^{60}$ London Stock Exchange terms of use <http://www.londonstockexchange.com/global/legal/disclaimer.htm> accessed 14 May 2015.

${ }^{61}$ For example, clause 7 of the terms of use of the Telegraph, provides for the grant of a royalty-free perpetual licence of the copyright in the content contributed by the users in favour of the newspaper. <http://www.telegraph.co.uk/topics/about-us/3692012/Terms-and-Conditions.html>, accessed 14 May 2015.

${ }^{62}$ For example, clause 2 of the terms of use of Facebook provides that users who upload copyright content own rights in their content, but provide Facebook non-exclusive, transferable, sub-licensable, royalty-free, worldwide licence. <https://www.facebook.com/legal/terms>, accessed 14 May 2015.

${ }^{63}$ Chapter III, sections 1.3.1, 1.3.2 and 1.3.3 above.

${ }^{64}$ Contract stage would have to be considered if there was a possibility of an assignment instead of a licence being implied, like in commissioning contracts. See Chapter IV, section 2.1.1 above. However, the terms of use that amount to a contract are likely to be more in the nature of copyright exploitation contracts or consumer contracts, but not commissioning contracts. Therefore, the likelihood of having to consider contract stage is remote.
} 
contract are also the knowledge of the terms of use themselves and of the surrounding circumstances. ${ }^{65}$ Therefore, regardless of whether the terms of use amount to an express bare licence or a contractual licence, the terms can be assessed under the same components of knowledge. The effort will be to ascertain how a licence may be implied into these terms enabling browsing, hyperlinking and indexing.

At one end of the spectrum, a copyright owner might simply provide (C) sign, with or without the words 'All rights reserved'. These words convey no more than the fact that copyright is claimed. Since copyright is an automatic right, even without such symbol or the words, copyright in the content on the website is protected. Therefore, the situations where this expression is used is not different from a situation where no terms of use are incorporated. Since browsing, hyperlinking and indexing are not expressly prohibited under these terms, it would be fair to conclude that the copyright owner's objective was to benefit from these functions. Therefore, the discussion under section 1.3.1 above in relation to browsing, hyperlinking and indexing will equally apply to these situations.

This part begins the discussion with websites which provide that only private and noncommercial use of the content is permitted, and that any commercial use must be authorised by an express licence. Even in the absence of this term, there could have been no licence implied by the mere placing of copyright content on the internet, to use the content for commercial gain, especially a use involving the exercise of exclusive rights. For example, no person can download content from the internet, print and sell copies of it, regardless of whether there are terms of use prohibiting it, on the basis that it will not be within the knowledge of the copyright owner that such use of her content will be made. To the extent that the copyright owner has willingly placed her content on the internet (positive act) and

\footnotetext{
${ }^{65}$ Chapter IV, sections 2.2.2.3 and 2.3.2 above.
} 
stood back with terms of use (partial neutral act), it will be a matter of interpreting 'commercial use' in such a way that implying a consent-based licence to permit browsing, hyperlinking and indexing, may still be explored.

This part will then move on to consider situations where a copyright owner might specifically prohibit acts such as linking, scraping, caching and indexing, without the copyright owner's consent. Under these circumstances, it will be difficult to imply a consent-based licence. Even if these functions are established as customs, such customs cannot override these express terms. As such, implying a policy-based licence must be considered.

If these terms of use amount to a contract, the methodology in Chapter VI will apply. ${ }^{66}$ Even if the terms of use do not amount to a contract, but are express bare licences, since there is a certain voluntariness to the copyright owner's actions, the methodology in Chapter VI can apply by analogy. The methodology requires that firstly, the contract in question must be classified so that a licence is implied into all contracts of that type. The website terms of use, being more in the nature of copyright exploitation contracts or consumer contracts, are a sufficiently discrete type of contracts. Secondly, the reasonable necessity of implication must be established. Therefore, based on the respective policy considerations for permitting linking and indexing, a policy-based licence can be implied.

\subsubsection{Browsing}

When the terms of use prohibit 'commercial use', is it still possible to imply into these terms a consent-based licence permitting browsing? It happens generally with news aggregators who take copyright content from newspaper/magazine websites, and offer a service to their own clients for a fee, to receive and view only the content of relevance to them. Should such use

\footnotetext{
${ }^{66}$ Chapter VI, sections 1.1.1 and 1.1.2.
} 
by news aggregators be regarded a commercial use of the content? More specifically, if the clients of the news aggregators are commercial entities, should their mere viewing of the such content be regarded as commercial use?

It might help again to go back to the offline example of P's art exhibition, and her pamphlet placed in a public place, incorporating her photographs of her art. If she incorporates a sentence at the bottom of the pamphlet that any commercial use of the pamphlet is prohibited, does it mean that she is prohibiting people also from simply viewing her pamphlet? The very objective of her placing the pamphlet in a public place means that she wants the public to see it. Commercial use in this context could mean for example, making copies of the photographs in the pamphlet and selling it. Even if Q, a commercial art collector, benefits from the pamphlet, Q's viewing of the pamphlet alone cannot be regarded a commercial use. In any event, viewing a copyright work is not a restricted act.

Likewise, when a copyright owner places her works on the internet, even with a term of use prohibiting commercial use, such term cannot mean that the mere viewing is prohibited, even if a person commercially benefits from viewing or reading the work. Although such viewing itself makes on-screen and cached copies of the work due to the technological process of browsing, such copying cannot be regarded as being for commercial use when the reason for such copies, namely viewing of the website itself cannot be regarded a commercial use. Therefore, the copyright owner's placing the content on the internet knowing that on screen and cached copies of the work will be created, together with the interpretation of commercial use adopted here, it is possible to imply a consent-based licence to permit browsing.

There is also a clear public policy in interpreting commercial use not to include browsing. An analogy could be drawn from the decision in Solar Thomson Engineering Co Ltd $v$ 
Barton ${ }^{67}$ Here, the right of repair was not a restricted right of the copyright owner, but permitting the owner of a chattel to prolong its life by making repairs is a matter of public policy. However, to effect repairs, copies of the copyright drawings must be made. Therefore, to give effect to the public policy, a licence to copy the drawings is implied from the owner in favour of the user/purchaser of the chattel. Similarly, the right to view and read a copyright work is not a restricted act. ${ }^{68}$ However, as a matter of policy, information placed on the internet without technological protection must be available for viewing and reading by the users. Viewing creates copies of the work. Therefore, to give effect to this policy, a licence may be implied to permit making copies of the content on the internet to enable browsing.

However, the UK courts chose to take the L\&E route, although an implied licence approach could have been easily adopted in Newspaper Licensing Agency v Meltwater Holdings BV ${ }^{69}$ Here, the plaintiff (NLA) was a licensing body, of which the publishers of many national newspapers are members. ${ }^{70}$ The first defendant (Meltwater), a news aggregator, used crawling robots to scrape content from the newspapers and prepared its own index. It provided commercial news aggregating service called Meltwater News, which is an online periodic newsletter for its clients, with headlines as links, opening words and summary of all articles published within that period containing the search term that their clients had chosen, for a fee. ${ }^{71}$ The fee covered not only the links delivered, but also the content displayed on the clients' monitors. The second defendant, Public Relations Consultants Association (PRCA),

\footnotetext{
${ }^{67}[1977]$ RPC 537.

68 [2013] UKSC 18 [1] (per Lord Neuberger); see also Michael Hart, 'The legality of internet browsing in the digital age' [2014] EIPR 630, 633.

${ }^{69}$ [2010] EWHC 3099 (Ch).

70 ibid [1].

71 ibid [25]-[26].
} 
represented the interests of public relations consultants, many of whom were clients of Meltwater's. ${ }^{72}$ The issue, among others, was whether the members of the PRCA (PRCs) required a web end-user licence (WEUL) from NLA to receive and view Meltwater News, in addition to Meltwater requiring its own licence from NLA. ${ }^{73}$ Meltwater also contested that it needed a licence from NLA, but had agreed to enter into a licence on such terms as the Copyright Tribunal fonud reasonable. ${ }^{74}$ NLA also contended that some of the PRCs send Meltwater News to their own external clients, which required PRCs to get a WEUL. ${ }^{75}$

The terms of use of all newspapers prohibited the use of their content for commercial purposes. Some newspapers had specifically stated that commercially operated news aggregators and their end users both require a licence to use their content. ${ }^{76}$ NLA contended that by 'receiving and viewing' the Meltwater News, the PRCs would be making copies of the copyright content, infringing the newspaper publishers' copyright. ${ }^{77}$ PRCA on the other hand, contended that the licence to Meltwater to provide Meltwater News implies a licence for its clients to receive and view it on their screen. ${ }^{78}$

Proudman J was willing to accept that Meltwater's licence to provide Meltwater News meant an implied licence in favour of the PRCs to receive Meltwater News. ${ }^{79}$ But she did not accept that this licence extended to viewing Meltwater News, as viewing (browsing) generated

\footnotetext{
72 ibid [4].

73 ibid [6], [8] and [22].

74 ibid [13].

75 ibid [8].

76 ibid [95].

77 ibid [45].

78 ibid [48].

79 ibid [51].
} 
copies whether they received it as a newsletter or visited Meltwater's website. Such copying, Proudman J opined, was not covered by implied licence. ${ }^{80}$ As such, she held that there is prima facie infringement, unless an exception applied. ${ }^{81}$

Clearly, Proudman J adopted a rigid approach. NLA’s licence to Meltwater to provide Meltwater News consented to the whole activity of providing such news. There would be no use of Meltwater providing the news if its clients could receive it, but could not view it without an additional licence. That NLA's licence to Meltwater would have authorised Meltwater to provide Meltwater News must have been within the knowledge of the concerned newspapers, who were in any event, members of the NLA. The fact that viewing of Meltwater News creates on screen and cached copies of the copyright works is also well within the knowledge of both NLA as a collecting society, and its member newspapers. Therefore, such knowledge should have been sufficient to imply a consent-based licence in favour of the PRCs, enabling the PRCs to browse Meltwater News.

However, Proudman J did not consider implied licence any further, but turned her attention to art 5(1), Infosoc Directive. She held it to be not applicable because the cached copies were not authorised and therefore, not a lawful use; the on screen and cached copies were not an integral and essential part of technological process, because there was human volition involved in creating those copies; and the on-screen copies had an independent economic significance because those copies were the very product for which PRCs paid Meltwater. ${ }^{82}$ The Court of Appeal confirmed Proudman J's decision, ${ }^{83}$ and did not consider

\footnotetext{
80 ibid [49]-[55].

81 ibid [101]-[105].

82 ibid [109].

83 [2011] EWCA Civ 890.
} 
implied licence at all.

The Supreme Court reversed the High Court and Court of Appeal's decisions, but only as to the interpretation of art 5(1), with no reference to implied licence. It held that viewing of a website can be a lawful use, since viewing of an infringing website, like reading an infringing book, is not a restricted act. ${ }^{84}$ Likewise, a person who merely views or reads an infringing copy of a work on the internet infringes no copyright in such work. ${ }^{85}$ The Supreme Court further clarified that the economic significance of a copy required under art 5(1) is a significance independent of its value as a display copy. Since on-screen copies only had value as display copies, they lacked independent economic significance. ${ }^{86}$ Although the Supreme Court also held that browsing is covered by the temporary copying exception under art 5(1), it referred the matter to the CJEU for reconfirmation on the impact of human volition on art 5(1). The CJEU held that the copies produced during browsing do not lose their incidental nature merely because there is human intervention in initiating and terminating their production, as these copies exist only so long as the technological process of browsing continues. ${ }^{87}$

With the CJEU's ruling now, although browsing has been brought under art 5(1), implied licence would have still provided a more flexible way of approaching browsing. While art 5(1) focuses on the technicalities of browsing as a function, implied licence focuses on the conduct of the copyright owner, content users and the policy objectives to be achieved, all of which are flexible criteria that can respond to different facts of a case. This technical approach

\footnotetext{
${ }^{84}$ Recital 33, Infosoc Directive defines lawful use as a use authorised by the rightholder or not restricted by law.

${ }^{85}$ [2013] UKSC 18 [1].

86 ibid [27], relying on Case C-403/08 FAPL v QC Leisure [2011] ECR I-9083 [179], the Court noted that this requirement should be read in a way as to encourage new technologies and not to impede them.
}

87 [2013] UKSC 18 [29]-[33]. 
has the danger of losing such flexibility. This will be evident when one considers the issue of browsing of infringing content on the internet, discussed in section 3.1 below.

Thus, where the terms of use prohibit commercial use of the copyright content, it is still possible to imply a consent-based implied licence to permit browsing, where the copyright owner has the knowledge of the on-screen and cached copies being made. Alternatively, it is possible to permit browsing by a policy-based implied licence. However, the courts thought it fit to permit browsing entirely based on the L\&E in art 5(1), Infosoc Directive, giving up the flexibility offered by implied licence.

\subsubsection{Hyperlinking}

When the terms of use prohibit commercial use, is it possible to imply a consent-based licence into those terms, permitting hyperlinking? Although linking was not specifically at issue in Meltwater, it is a good example of commercial value of linking as a content delivery mechanism.

In Meltwater, the newspapers had published their content on the internet free of charge and free of access restrictions, but with terms of use prohibiting commercial use of the content. However, Meltwater charged its clients a fee to receive the same content through the delivery mechanism of linking. Linking for private and non-commercial purposes was within the knowledge of the newspaper publishers as normal use of their content. However, a use like that of Meltwater's, charging a fee to provide links to freely available content could not have been within the publishers' knowledge or contemplation as normal use of their content.

Meltwater might argue that they did not make commercial use of the content itself, but charged their clients a fee only to point to such content. However, Meltwater's clients' only interest in the links was to click through and get to the content they pointed. Even if Meltwater built the infrastructure to connect its clients to the content, ultimately it is the content which Meltwater's clients are interested in. If the newspapers did not provide content, 
there would be nothing that Meltwater could provide in its Meltwater News as links. Due to the direct relationship between linking and the content, as a matter of interpretation, commercial use of the content will include linking to the content for a fee. Therefore, when the terms of use exclude commercial use of the content, it is difficult to imply a consent-based licence to permit hyperlinking.

One may explore if a custom-based licence may be implied to permit hyperlinking in this context. Even if hyperlinking as such satisfies most criteria discussed in section 1.3.1.2 above, the difference here is that hyperlinking for commercial purposes might not satisfy the criterion of reasonableness and a balanced allocation of rights. Even if linking without authorisation is a custom, ${ }^{88}$ it does not follow that the person so allowed to link can make money out of linking. In other words, a custom that requires content providers to make their content freely available for linking, but lets the person who links, to then go on to make money from it, is not likely to be regarded a reasonable or a balanced custom. Therefore, it is unlikely that linking for commercial purposes will be regarded a custom for it to become the basis for implying a licence in favour of users like Meltwater.

One may also explore if a policy-based licence can be implied. The policy of content having to be freely available for linking is reasonably necessary for the efficient functioning of the internet. ${ }^{89}$ However, to let the persons providing the links to make money out of such linking at the expense of the content owners cannot be regarded as reasonably necessary. If the terms of use prohibit all linking (e.g. Ryanair ${ }^{90}$, whether for commercial or noncommercial purposes, then it may be argued that implying a policy-based licence to permit

\footnotetext{
88 Polanski (n 27) 307-11.

${ }^{89}$ Case C-160/15 GS Media BV v Sanoma Media Netherlands BV [2016] WLR(D) 477 [45].

90 Terms of Use, clause 5, <https://www.ryanair.com/en/terms-of-use/>, accessed 21 December 2016.
} 
non-commercial linking is reasonably necessary. If the terms of use only prohibit commercial use, then it will be difficult to imply a policy-based licence to permit hyperlinking.

However, as discussed above, courts have not adopted the doctrine of implied licence to explain hyperlinking. Instead, courts have adopted the concept of new public in Svensson, which envisages a binary situation where content is either freely available without restrictions, or technologically protected. The decision hinges on what is 'accessible' to the user, rather than what is 'authorised' by the copyright owner. The effect of this reading is that regardless of the terms of use withholding the copyright owner's consent for certain uses, if the content is technologically accessible, it will still be regarded as freely accessible. Applying Svensson will mean that a new public does not come into existence merely because the terms of use say so, if the content is otherwise freely accessible. Even if a person links the content for commercial purposes, it will not be held to be an infringement under Svensson. This conflates the assessment, and risks leading to unfair results.

Thus, when terms of use bar commercial use, it will be difficult to imply a consentbased, custom-based or a policy-based licence to permit hyperlinking for commercial purposes. This shows that the doctrine of implied licence is not only more receptive to a copyright owner's consent, it also goes on to assess the possibilities of a custom-base and a policy based licence. However, the courts have favoured the rigid discourse of new public.

\subsubsection{Indexing}

If the terms of use exclude commercial use, is it possible to imply a consent-based licence into those terms to permit indexing? As noted in section 1.3.1.3 above, since the expression of consent in case of indexing is a matter of the conduct of the copyright owner in setting the codes, how do terms of use interact with the code? 
Where the terms of use prohibit 'commercial use', a distinction may be made between scraping by search engines and scraping by news aggregators. Search engines profit normally from the advertising revenue, and their profit is not directly attributable to or at the expense of the copyright content they scrape. On the other hand, news aggregators profit directly from the content they scrape, as explained in section 1.3.2.2 above. The utility of the search engines indexing the enormous content on the internet will likely outweigh the commercial nature of its activity. However, the commercial nature of news aggregating services is likely to be caught by the prohibition on commercial use.

Accordingly, copyright owners might want to allow a 'free-of-charge' search engine to scrape its data, but not a 'for-profit' news aggregating service, in such a way that their terms of use do not affect search engines like Google, but ensure that news aggregators follow them. This was seen in Meltwater, where the newspaper publishers made their websites freely available for search engines to scrape, ${ }^{91}$ cache and index, but objected to only the news aggregators scraping their websites, as indicated by the terms of use of some of their websites. The codes were not in issue in Meltwater. Nevertheless, a perusal of the current version of NLA's standard Web Database Licence makes it clear that scraping of their website is only allowed under a licence. ${ }^{92}$ A collective licensing scheme like the NLA's indicates a push towards making news aggregators honour the terms of use, rather than take comfort in the code settings.

Although there are codes which generally instruct any crawling software, larger search engines like Google do provide for codes that are specific to Google's crawling software. ${ }^{93}$ It

91 The High Court noted in the decision in Meltwater that the newspaper publishers had 'arrangements or understandings' with certain 'free' news aggregating services such as Google News and Google Alerts whereby those services were 'licensed or otherwise permitted.' [2010] EWHC 3099 (Ch) [20].

92 < http://www.nlamediaaccess.com/uploads/public/WDL\%20April\%202016\%20Tariff.pdf> accessed 20 December 2016.

93 <https:// support.google.com/webmasters/answer/79812?hl=en> accessed 20 December 2016. 
is possible for copyright owners to only let search engines like Google to scrape their content, and disallow all other crawling software. For newspaper/magazine websites, this is a viable solution. When news aggregators' crawling software is instructed not to scrape a particular newspaper website, then it means that such news aggregator must approach the newspaper for a licence to do so. This will not place additional burden on news aggregators. The crawling software of these organisations do not crawl all of the internet, like Google's crawlers do. Their crawling software is designed to crawl specific newspaper websites. Since news aggregators have control over creating the list of websites to crawl, it is reasonable to expect them to go through the terms of use of each website they crawl. This will not be possible for search engines like Google which do not have a pre-determined list of websites to programme their software to crawl. Thus, creating such discriminating technological response and building it into implied licences will lead to reasonable results for all parties concerned.

Some commentators insist that the incorporation of the codes be regarded as only one of the ingredients informing the existence of consent. They suggest other circumstances also to be considered, such as: the commercial nature and frequency of scraping; and the control exercised on the copyright content by the person scraping. ${ }^{94}$ However, a case-by-case assessment of whether scraping should be allowed might increase the transaction costs of both search engines and news aggregators. The discriminating technological response incorporated into implied licence as described above, may be a preferable option.

However, if no codes are incorporated because the copyright owner does not know of the existence and the functions of the code, then the possibility of imputing the knowledge of the code by establishing it as a custom can be explored, as explained in section 1.3.1.3 above.

\footnotetext{
94 Tanya Pihlajarinne, 'Setting the Limits for the Implied License in Copyright and Linking Discourse -- The European Perspective' [2012] 43(6) IIC 700, 709, 710.
} 
It may be difficult to establish the practice of employing the codes to discriminate between search engines and news aggregators, as a custom, as it may not be sufficiently notorious. If established, however, the knowledge of using the discriminating code may be imputed to the copyright owner, implying a custom-based licence in favour of search engines to scrape.

If the terms of use specifically prohibit all scraping, ${ }^{95}$ but the copyright owner sets the code to allow scraping or has set no code at all, crawling software will go ahead to index such websites. In this situation, a policy-based implied licence can be considered. Since crawling is an automated process facilitated by a software, the software cannot be expected to read the terms of use and understand that no scraping is permitted. In that case, one may have to rely on the public interest in the search engines organising and indexing the vast swathes of information on the internet, based on which to imply a licence. Thus, search engines are more likely to benefit from a policy-based implied licence for meeting the standard of reasonable necessity, as the profit they make is not necessarily at the expense of copyright content. It will be difficult to argue that it is reasonably necessary for a profit-making news aggregators to benefit from a policy-based implied licence, as it profits directly from providing access to copyright content.

The approach taken in the German case of Google Image Search (Vorschaubilder) ${ }^{96}$ resonates more with the policy-based licence than with consent-based licence, though the court called it an implied consent. Here, an artist had maintained a website on which she had displayed images of her work. The artist had placed no codes in building her website. Google crawled her website and indexed these images as thumbnail images, and provided them as

\footnotetext{
95 See for example Telegraph terms of use, cl 6(6) < http://www.telegraph.co.uk/topics/aboutus/3692012/Terms-and-Conditions.html> accessed 21 December 2016.

${ }^{96}$ Federal Supreme Court, 2010 GRUR 628, cited from Matthias Leistner, 'The German Federal Supreme Court's Judgment on Google’s Image Search’ [2011] 42 IIC 417, 423-30. See also Birgit Clark, 'Google Image Search does not infringe copyright, says Bundesgerichtshof [2010] 5 JIPLP 553.
} 
search results whenever anyone searched the claimant's name. ${ }^{97}$ The Federal Supreme Court held that the making available of these images without the code settings that indicate whether the contents of the website can be scraped, amounts to implied consent to crawl, scrape and index the content. The Court went a step ahead to hold that even if a copyright owner incorporated terms of use on its website (which it refers to as individual notification), if the codes have not been set to disallow scraping, it conveys an implied consent to scrape. ${ }^{98}$ The court did not consider whether the claimant had the actual knowledge of the existence of such codes in the first place, to instruct Google's crawling software, although it referred to an implied consent from the copyright owner. To the extent that the court emphasised the organising function of search engines and that copyright owners ought to know the existence and the use of the codes, the court's reasoning reflects a combination of policy-based and custom based licence, rather than a consent-based licence.

Thus, if the terms of use generally prohibit commercial use of the content, then a combination of consent-based and custom-based licences can permit indexing fr commercial purposes. If the terms of use specifically prohibit all scraping, a policy-based implied licence could permit indexing by larger search engines. If the terms of use exclude indexing by news aggregators, but the code is set to allow indexing by specific search engines, a consent-based implied licence only extends to the search engines. The news aggregators must obtain permission from the copyright owner for indexing.

\section{Incorporating a Paywall}

Even if a content owner places her content on the internet indicating a positive act, if the

\footnotetext{
972010 GRUR 628, 629, para 16.

98 ibid paras 37-39.
} 
content owner does not leave the content freely available on the internet, but instead incorporates the TPMs (including paywalls), then there is little basis for implying any licence. In Svensson, the CJEU stated that incorporating the TPMs is one of the ways in which the content owner could demarcate the public to whom the communication is directed. Accordingly, circumventing the TPMs communicates the content to a public not contemplated by the copyright owner, thereby creating a new public. Thus, the TPMs act as a mechanism by which the content owner controls access to the content. ${ }^{99}$

When the TPMs are in place, browsing, linking and indexing the content are all restricted. Browsing will only be possible if the user gets authorisation to go beyond the TPM. As for linking, even if a person lawfully gains authorisation and finds the web address, the web address is unlikely to work as a hyperlink. A person who clicks on a link of content protected by the TPMs will only gain access up to the page before the TPM, requesting her to take the necessary action (such as payment) to gain access. Circumventing TPMs is prohibited. ${ }^{100}$ Therefore, the existence of the TPMs is a clear denial of permission, and the only way to gain permission is to act in the manner required by the content owner.

Once a user gains access to content, having performed the actions that gain her access, such as payment and agreeing to terms and conditions, issues arise as to the user's relationship with the copy of the content. Is it her purchased copy or is it a licensed copy? The distinction matters because if it is a sale, then the right of distribution is exhausted, freeing the user to resell her goods further on, without the need for an authorisation from the copyright owner. A landmark decision of the CJEU held that the downloading of a software in exchange for payment can be regarded as a sale if the price is reflective of that, and if the licence to use the

\footnotetext{
${ }^{99}$ Svensson (n 32) [31].

100 CDPA, s 296ZA.
} 
software is perpetual. ${ }^{101}$ However, for the reasons explained in Chapter VI, section 2.2 above, this thesis does not regard exhaustion as part of the implied licence debate, whether in the offline or online environment. Therefore, this issue is not discussed further.

\section{Content Placed without Copyright Owner's Consent}

The content placed on the internet without the copyright owner's consent infringes the copyright owner's exclusive right of communication to the public. However, given the universal utility of browsing, hyperlinking and indexing, should it still be possible to imply a licence to permit these actions?

Copyright content comes to be placed on the internet without the copyright owner's consent either because the copyright owner never placed the content on the internet, or because the TPMs protecting the copyright content are removed. In the former scenario, the first step that signals a consent-based implied licence, namely the copyright owner's positive act of placing the content on the internet is absent. In the latter, the removal of the TPM changes the copyright owner's conditional neutral act into an absolute neutral act. Since the resulting absolute neutral act is not the copyright owner's conduct, it cannot be considered towards her consent. In the absence of the positive and the neutral acts, there is no point in assessing the knowledge of the copyright owner (as per Chapters III and IV). Since the copyright owner has not chosen to be part of the online community (by not consenting to her content being placed online), there is no possibility of implying a custom-based licence (as per Chapter V). Since there are no terms of use (as the copyright owner did not authorise her content to be placed on the internet), no possibility of a policy-based implied contractual licence either (as per Chapter VI). If there is any licence to be implied at all, it must be a policy-

${ }^{101}$ Case C-128/11 Used Soft GmbH v Oracle International Corp [2012] ECDR 19. 
based bare licence as per Chapter VII. And the framework involves an assessment as to whether the exercise of the powers under s 171(3) complies with the three-step test; and if not, whether it complies with the FR regime.

This section explores if a limited licence permitting browsing, linking and indexing of infringing content can be implied exercising the common law powers under s 171(3), CDPA, to give effect to the public interest inherent in each of these actions. When public interest is guided by the three-step test, in assessing whether the use of a work interferes with the normal exploitation and the legitimate interests of the copyright owner, considerations such as the knowledge of the users as to the infringing nature of the content become important. Whether these factors also affect the assessment under the FR regime depends on the strength of the argument in favour of upholding the FRs of the users, as discussed below.

\subsection{Browsing}

Browsing of infringing content creates infringing on-screen and cached copies. If browsing as an activity can be held to be in public interest, then it can be read into the common law powers under s 171(3) to imply a policy-based licence permitting browsing of infringing content.

Since browsing is the way the internet users can perceive the content on the internet, it is fundamentally important to enable browsing unhindered, thereby promoting public interest. Let us examine how such reading of the public interest responds to the three-step test. Firstly, browsing is a sufficiently specific case. Secondly, browsing does not interfere with the normal exploitation of the work because the on-screen and cached copies so created do not have a value outside the act of browsing. Further, it is arguable that the normativity of normal exploitation must take into account the fundamental importance of browsing on the 
internet. ${ }^{102}$ However, if a person browses the internet knowing the infringing nature of the content, regardless of whether she pays for such browsing, the on-screen and cached copies created might interfere with the normal exploitation of the lawful copies of the work. For example, if a person subscribes to a streaming service to watch infringing films, even if the onscreen and cached copies so generated are only temporary, it is arguable that these very copies compete with the lawful copies of the films. Thirdly, knowingly browsing infringing content may also conflict with the legitimate interests of the copyright owner in maintaining a market for the lawful copies. Thus, it may be difficult to pass the three-step test if a person browses content knowing of its infringing nature.

Therefore, the FR regime must be considered. Regarding compatibility, ${ }^{103}$ since browsing opens up to the internet users the vast repository of information, browsing plays a vital role in protecting the right to freedom of information, engaging art 10, ECHR and art 11, CFREU. These rights can only be interfered with for considerations such as protecting the rights of others in a democratic society, among others (under art 10(2), ECHR, art 52(1), CFREU). This engages the copyright owners' A1P1 and art 17(2), CFREU rights, which can only be interfered with in general interest. Such interference is only justified if it is proportionate or strikes a fair balance. ${ }^{104}$

If there is infringing content on the internet, the rights of copyright owners can be protected by pressing into service the provisions of the CDPA that hold liable the person who created the infringing copy by either circumventing the TPMs, ${ }^{105}$ or by making a business out

\footnotetext{
102 See Chapter VII, section 2.2 above.

${ }^{103}$ See Chapter VII, section 4.1.2 above, assuming that applicability is not an issue.

${ }^{104}$ See Chapter VII, sections 4.1.2.1 and 4.1.2.2 above.

105 CDPA, s 296ZA.
} 
of infringing copies, ${ }^{106}$ rather than the person who browses infringing copies. Dealing with the issue of liability in this manner goes to the root of the infringement, rather than addressing the relatively innocuous temporary copies. Given the fundamental importance of browsing for the protection of art 10, ECHR, this interpretation will comply with the less invasive option which the ECtHR applied in Balan v Moldova ${ }^{107}$ It will also strike a fair balance among the fundamental principles mentioned in recital 3, Infosoc Directive, namely public interest, freedom of speech (art 11, CFREU) and intellectual property rights (art 17(2), CFREU), as affirmed by the CJEU in Case C-201/13 Deckmyn v Vanderstee. ${ }^{108}$ This interpretation also upholds the general interest in permitting browsing unhindered against the assertion of A1P1 or art 17(2), CFREU right. Therefore, knowingly browsing of infringing content can still comply with the FR regime.

Instead of the flexible approach of implied licence, the CJEU and the UK courts have adopted the rigid L\&E route to enable browsing. A recent opinion of the AG in Case C527/15 Stichting Brein v Jack Frederik Wullems, states that streaming of infringing content is not 'lawful use' under art 5(1), Infosoc Directive, and even if streaming infringing content was covered under art 5(1), it does not pass the three-step test. ${ }^{109}$ In the AG's own words, a 'highly technical assessment' is necessary to interpret art 5(1), rather than 'forming a general view of streaming. ${ }^{110}$ The technical approach raises problems also on the need for independent economic significance of the temporary copies under art 5(1) because, the very copies that appear on-screen and in the cache have economic value which the subscribers pay to a

\footnotetext{
${ }^{106}$ CDPA, s 23 and the tortious liability of authorising infringement as crystallised in Twentieth Century Fox Film Corporation v Newrabin Ltd [2010] EWHC 608 (Ch) [90].

107 App no 19247/03 (ECtHR, 29 January 2008) [7]-[18]. See Chapter VII, section 3.1.2.1.

108 [2014] WLR(D) 385 [25]-[26].

${ }^{109}$ ECLI:EU:C:2016:938, Opinion of the AG Sanchez-Bordona, paras [71]-[72], [77].

110 ibid [65], [67].
} 
streaming service. Further, the AG's assessment of browsing based only on the compliance with the three-step test loses sight of the arguments on the FR regime. The CJEU has now given the decision confirming the AG's opinion, raising no arguments on the FR regime. ${ }^{111}$

Thus, applying the framework for implying policy-based licences is a preferable approach to adopt. Under this framework, browsing of infringing content answers the threestep test if the person does so unknowingly. But browsing of infringing content knowingly can still comply with the FR regime.

\subsection{Hyperlinking}

Hyperlinking to infringing content communicates the infringing works to the public, thereby infringing the copyright in such works. If hyperlinking as an activity can be held to be in public interest, then a court can be asked to read it into its common law powers under s 171(3) to imply a policy-based licence permitting hyperlinking of infringing content.

There is a clear public interest in maintaining the network of connections within the internet through hyperlinking. Given the enormity of the content on the internet, access to information becomes more efficient with the ability to link freely. Let us examine how reading such public interest into s 171(3) responds to the three-step test.

Firstly, hyperlinking is a sufficiently specific case. The second requirement that such hyperlinking not interfere with the normal exploitation of the work requires a more detailed consideration. One might argue that hyperlinking is different from browsing in that a person can make a profit from the very act of communicating a work to the public through hyperlinking; whereas a person does not make a profit from the temporary copies created by

111 ECLI:EU:C:2017:300. 
browsing. However, the knowledge of the infringing nature of the content is more important than the pursuit of profit, as the following four possibilities demonstrate.

If the person who links to infringing content is unaware of or cannot reasonably ascertain its infringing nature, and:

- does not link for profit, then it is arguable that it will not interfere with normal exploitation of the work. It is arguable also that the normative aspect of normal exploitation recognises the inherent value in linking without hindrance.

- links for profit, then normatively, it would interfere with the person's ability to freely link to content if she must monitor all content she links to, for its infringing nature. Even if such pursuit of profit interferes with normal exploitation, it may be possible to pass this step if a court can be persuaded of this normative angle to normal exploitation.

If the person who links to infringing content is aware of its infringing nature and:

- does not link for profit, she might still interfere with the normal exploitation of the work. For example, a person sharing a link to an infringing copy of a film for free, knowing of its infringing nature, interferes with the normal exploitation of the lawful copies of the film. This is because the availability of the infringing copy for free competes with and reduces the marketability of the lawful copies. This weakens an argument on normativity.

- links for profit, she interferes with the normal exploitation of the work because the infringing copies will be in direct competition with the lawful copies, and it will be difficult to support that normatively a person who knows of infringing nature of the content should be permitted to link and make profit out of it. 
The third step of interference with the legitimate interests of the copyright owner involves balancing of competing interests. It may be possible to pass this test in relation to the first two scenarios above, given the difficulty in monitoring the content as to its infringing nature. The interests of the internet users in these two scenarios might outweigh the interests of the copyright owner. However, in the third and the fourth scenarios above, the balance might tip in favour of the legitimate interests of the copyright owners.

Thus, a person unknowingly linking to infringing content is more likely to pass the three-step test than a person knowingly linking to infringing content, with the profit motive being less important.

For those scenarios that do not satisfy the three-step test, the FR regime can be considered. Since there is a direct relationship between access to information and hyperlinking, hyperlinking plays a vital role in furthering the internet users' right to freedom of expression and information, and therefore art 10, ECHR and art 11, CFREU are engaged. Similar to browsing, copyright owners' A1P1 and art 17(2), CFREU rights are engaged, which can only be deprived in general interest. In an assessment of proportionality, unlike in browsing, it is difficult to pursue the least onerous measure by holding someone other than the person who hyperlinks liable for the infringing content. A person who browses infringing content is able to access such content because someone made it available, likely through linking. Therefore, it makes sense to hold the person who communicates, including by linking, liable for infringement, rather than the person who browses.

In striking a fair balance, it will be difficult to argue that the freedom of expression of a person who knows of the infringing nature of the content through linking should be protected over and above the rights of copyright owners in a democratic society. A court is unlikely to be persuaded by an argument that the copyright owners' rights should be interfered 
with in the general interest in permitting internet users to knowingly link to infringing content, regardless of whether they pursue profit.

Therefore, even under the fundamental rights regime, a person who knowingly links to infringing content is unlikely to benefit from a policy-based implied licence to link to infringing content.

The question of linking to infringing content came up in Case C-160/15 GS Media v Sanoma Media Netherlands $B V \cdot{ }^{112}$ In this case, certain copyright protected photographs had been uploaded to the internet by a third party without the consent of the defendant, the copyright owner. An online magazine, GS Media provided a link to these photographs on its website, knowing that the photographs infringed Sanoma's copyright. The CJEU held that for Svensson rule of exempting linking from communication to the public to apply, the content on the internet must have been placed with the copyright owner's consent. ${ }^{113}$ If the initial placing of the content on the internet lacks copyright owner's consent, then not only the initial placing, but all subsequent linking will amount to an infringement.

However, the CJEU recognised that this could cause undue hardship in making all users ensure that the content they link to is not infringing. Abandoning its adherence to the concept of 'new public', the CJEU adopted an approach more in line with the FR approach described above. The CJEU cited the importance of the internet in promoting free speech under art 11, CFREU. Accordingly, the CJEU held that if the person linking to certain content does not pursue profit, and does not or cannot reasonably know of the infringing nature of the content, then the act of linking does not amount to communication to the public. ${ }^{114}$

\footnotetext{
112 [2016] WLR(D) 477.

113 ibid [41]-[43].

114 ibid [45]-[47].
} 
However, if a person does pursue profit, she will be expected to ascertain whether the content she links to is infringing. The Court went a step further in holding that if a person links for profit, there will be a rebuttable presumption against such person that she has posted the link with full knowledge of the infringing nature of the work. If she is unable to rebut such presumption, she will be held to have violated the right of communication to the public. ${ }^{115}$

This decision can be critiqued at two levels: firstly, the CJEU tried to make this decision look like an FR compliant interpretation of the right of communication to the public. However, if a certain content is not placed on the internet with the copyright owner's consent, the only way of permitting linking to this content is by disregarding such lack of consent in favour of achieving a larger policy objective. Such policy was found in recognising the crucial role played by linking in promoting freedom of expression. In disregarding consent of the copyright owner, and permitting users without the knowledge of the infringing nature of the content to link without having to ascertain its lawfulness, the Court implied in such users' favour a policy-based bare licence. Of course, the Court does not acknowledge that this is what it was doing, since a policy-based implied bare licence behaves like an L\&E, ${ }^{116}$ and the CJEU must respect the exhaustive list of L\&Es in the Infosoc Directive. However, had this case arisen in the UK, it would have presented the unique opportunity to press the common law powers under s 171(3) into service to permit unknowingly linking to infringing content.

Scholars criticise this decision for imposing the requirement of knowledge on part of the internet users as to the infringing nature of the content being communication to the public, as they argue that it blurs the distinction between primary and secondary infringement. They point out that the CJEU has impinged upon the secondary infringement of the communication

\footnotetext{
115 ibid [51].

116 See Chapter II, section 3.3.1 above.
} 
right which has not yet been harmonised. However, if the court's decision is rationalised not as an interpretation of the communication right, but as a policy-based implied licence scrutinised under the three-step test and the fundamental rights regime as argued above, the decision becomes more reasonable.

Secondly, the CJEU's decision hinges on the linker's pursuit of profit. As argued above, the knowledge if the infringing nature of the content is more important than the pursuit of profit in the assessment as to whether knowingly linking to infringing content can be permitted. Knowledge of the infringing nature of the content weakens the normative argument in normal exploitation, and the general interest argument under the FR regime, regardless of the pursuit of profit. Further, because of the presumption in this decision, if a person is unaware or cannot reasonably ascertain the infringing nature of the content, she must monitor all content for infringement if she pursues profit. ${ }^{117}$ Such need for monitoring could interfere with her right to conduct business under art 16, CFREU. Thus, the CJEU should have limited its analysis to the linker's knowledge of the infringing nature of the content.

Thus, implying a policy-based licence to permit hyperlinking is a better approach than the one adopted by the CJEU. Linking to infringing content can pass the three-step test if the person links without knowing the infringing nature of the content, regardless of the pursuit of profit. If she knowingly links to infringing content, she risks not meeting the requirements of both the three-step test and the FR regime, regardless of whether she pursues profit.

\subsection{Indexing}

Indexing infringing content results in making copies of the infringing content and communicating it to the public. If indexing as an activity can be established to be in public

\footnotetext{
117 See Case C-610/15 Stichting Brein v Ziggo ECLI:EU:C:2017:99, Opinion of AG Szpunar, para [52].
} 
interest, it may be possible to read it into s 171(3) to imply a policy-based licence to permit indexing of infringing content.

A distinction must again be made between general search engines and news aggregators. Search engines provide an important service of bringing order to the vastness of content on the internet, and in making the content readily accessible. This has a bearing on the rights of the internet users under art 10, ECHR and art 11, CFREU. Search engines must index all content on the internet, lawful and infringing, and the crawling software cannot discriminate the content while crawling. In order not to lose the significant public interest in permitting search engines to freely index the internet, it must be possible to read such public interest into the common law powers under s 171(3).

Such interpretation complies with the three-step test. Indexing is a sufficiently special case. Since the search engines make access to infringing content easier, copyright owners may claim that it interferes with the normal exploitation of their work. However, the inevitability of the search engines having to index both lawful and unlawful content can support an argument of normativity in the normal exploitation. It may also not prejudice the legitimate interests of the copyright owner, as the balance may tip in favour of allowing search engines for their role in access to information. However, if a search engine is made aware of the infringing nature of certain content it has indexed, continued indexing can interfere with both the normal exploitation and the copyright owner's legitimate interests. If the search engines provide a mechanism for reporting, which some do, ${ }^{118}$ and promptly take down such content from their index, then they can continue to benefit from a policy based implied licence. Search engines indexing infringing content is also supported by the FR regime.

$118<$ https://support.google.com/legal/troubleshooter/1114905?hl=en> accessed 18 February 2017. 
News aggregators, however, are likely to have more control over the websites they index, as they target only the sites that are of interest to their clients, although it is still possible for its crawling software to scrape and index infringing content. For example, a news aggregator might scrape a newspaper article hosted on a newspaper website which has infringing photographs. Under these circumstances, rules similar to linking should apply. If the news aggregator was unaware or could not reasonably ascertain the infringing nature of the content, then indexing of such content will pass the three-step test. If the news aggregator was aware of the infringing nature of the content, then neither the three-step test, nor the FR regime can permit indexing of infringing content.

No case has been decided directly on this point. ${ }^{119}$ The Federal Supreme Court of Germany has only observed as an obiter that a search engine indexing infringing content must benefit from an immunity similar to that accorded to the ISPs under art 14, E-Commerce Directive. ${ }^{120}$ However, commentators argue that the services provided by search engines cannot be strictly regarded as hosting services, and the services of search engines may not be sufficiently neutral. ${ }^{121}$ An authoritative decision on this point is awaited.

Thus, a general search engine indexing content on the internet is more likely to benefit from a policy-based implied licence for complying with the three-step test and fundamental rights regime, than a news aggregator pursuing profit.

\footnotetext{
119 The German Federal Supreme Court's decision in I ZR 140/10 of 19 October 2011 - Vorschaubilder II concerned copyright content that was not expressly authorised to be exploited on the defendant website, but was otherwise freely available on the internet. Google indexing this website was regarded not an infringement, emphasising Google's importance in organising content on the internet. Cited from Brigit Clark, 'Google image search still does not infringe copyright, reaffirms Bundesgerichtshof [2012]7 JIPLP 788-89.
}

1202010 GRUR 628, 633, para 39.

${ }^{121}$ Leistner (n 96) 433-4. 


\section{Conclusion}

Given that the doctrine of implied licence is well established in the analogue world, the same principles can also be used on the internet, with contextual modifications. Although in some cases, courts have found alternative methods to deal with the challenges, the doctrine of implied licence established in the previous Chapters provide a more flexible and targeted solution. Therefore, implied licences have the potential to respond to today's dynamic technological environment, in a theoretically sound and practically sensible manner. Instead of lamenting like Proudman J that she was taken to no authority on implied licence, ${ }^{122}$ judges and lawyers should do more to apply the doctrine of implied licence expounded in the analogue world to the online world. 


\section{Conclusion}

The effort in this thesis was to make the process of implication of a copyright licence more methodical and transparent. Towards this goal, it began with a conceptualisation of a licence that is broad enough to accommodate licences that arise in diverse circumstances, but certain enough to identify its constituents. Using this conceptualisation of a licence, it proposed frameworks for implying a licence based on the consent of a copyright owner, a custom and the intervention of a state actor. The thesis then set about to rationalise the existing case law with the frameworks proposed.

Since there was no framework to guide the implication of a consent-based bare licence, Chapter II proposed a framework, and Chapter III demonstrated how applying this framework could bring clarity to a court's reasoning. For implying a consent-based contractual licence, however, the widely-recognised principles of implying a term into a contract could have been applied. Chapter IV proposed a methodology of separating the contract stage and the licence stage of a contractual licence, and showed that applying principles specific to copyright law at the contract stage, and the framework for implying a consent-based licence at the licence stage, could bring greater clarity to the process of implication. For implying a custom-based licence, Chapter V accepted the well-established criteria of recognising a custom, but went on to refine them by adding concerns specific to copyright law. Also for implying a policy-based implied contractual licence, Chapter VI accepted the contract law principles of implying a term by law, and analysed the existing case law based on these principles to bring more clarity to the reasoning. Finally, Chapter VII identified a common law source under s 171(3), CDPA, granting a court the power to imply a policy-based bare licence, being guided by the three-step test or the FR regime, in exercising such power. Chapter VIII then went on to test and illustrate the analyses in the previous chapters in relation to three important functions on the internet browsing, hyperlinking and indexing. 
When faced with a case of infringement, while assessing the facts and circumstances, it is not always clear as to which framework must apply to the case. Just as the frameworks are not proposed as rigid rules for the courts to apply, they are also not proposed as independent and unconnected sets of criteria. The way in which the facts and circumstances of the case may flow through the frameworks is as follows (See also Chart II at the end of this Chapter).

The assessment of the facts and circumstances as to the existence of the positive act is a good starting point. This is because if the copyright owner did not even engage with the copyright work in a way that it could be used by the defendant, the most important requirement of consent is absent. In such case, the only possibility is to assess whether a policybased bare licence may be implied. If the positive act exists, then ascertaining at the outset whether it is absolute or conditional can give an initial clue as to whether the licence, if implied, will be contractual. Even if the positive act is not conditional, the neutral act being conditional will point to the licence being contractual.

Once the conduct of the copyright owner is assessed, one can move on to the assessment of the knowledge of the copyright owner. If the copyright owner knows about her copyright entitlement, the lack of bargain and of the circumstances in which the positive and the neutral act were performed, then a consent-based bare licence comes into existence. If the copyright owner knows of a bargain having come into existence and the circumstances in which the positive and the neutral act were performed, then a consent-based contractual licence comes into existence. If the copyright owner does not know of the circumstances, but must be imputed with the knowledge that she engaged in the positive and the neutral act in furtherance of a practice which has become a custom, then a custom-based licence can be implied. If the copyright owner knows of a bargain having come into existence, but it is more apt to attribute the implication to achieving a public policy goal, then a policy-based contractual licence can be implied. 
If there is no positive act, there is no neutral act too, and what is within the copyright owner's knowledge is immaterial. The assessment will then be whether there is a public policy worth enforcing under the common law rule under s 171(3), CDPA to restrict copyright enforcement. If yes, then the question will be whether restricting copyright enforcement for policy reasons may answer the three-step test. If yes, then a policy-based implied bare licence comes into existence. If no, it must be assessed if enforcing such policy is in compliance with the FR regime. If yes, then too, a policy-based bare licence may be implied. If no, then no copyright licence may be implied under the circumstances.

The knowledge of the copyright owner changes gradually as we move from Chapter III onwards. In Chapter III, the knowledge of the copyright owner is the actual knowledge, even if assessed objectively. In Chapter IV, it is the actual knowledge and the knowledge that the copyright owner ought reasonably to have, given the existence of the other contracting party whose reasonable expectations may have to be honoured. In Chapter V, it is the knowledge of a practice in a community imputed to the copyright owner as its member, because the practice has become a custom within that community. In Chapter VI, the copyright owner may have the knowledge of the circumstances, but it is more appropriate to attribute the implication to the enforcement of a policy. In Chapter VII, however, the knowledge of the copyright owner is immaterial, because the implication of a licence is to give effect to a policy objective, regardless of the copyright owner's consent. Thus, the actual knowledge gradually gives way to the policy objectives, as the underlying reason for the implication of a licence. Since knowledge is a component of consent, this also maps on to the changing role of consent.

Once a court does imply a licence, an ex post withdrawal or revocation of such licence by the copyright owner is prevented by the rules against such revocation discussed in Chapter II, section 2.3 above and in particular, the circumstance captured by proprietary estoppel in 
Chapter III, section 2 above. However, the most significant feature of implied licences is that an implication is possible only if there are no contrary express terms. Express words are given greater importance as a reflection of consent than that which can be implied by conduct, thereby making them override a consent-based implied licence. A custom can be overridden by expressly providing for a term contrary to the custom. Express words can also override a policy-based implied licences, by providing terms contrary to common law rulings. If a copyright owner attempts to incorporate such contrary express terms, courts may still ensure that such terms do not override implied licences too easily, by insisting on the clearest possible language to achieve an override. It is also possible for a court to conduct an overall assessment of the compliance of such express terms with the FR regime.

In any event, the need for the implication of a copyright licence will not disappear. The growing body of case law concerning implication of a term into a contract is a testament to the fact that there will always be incomplete contracts or undocumented arrangements. There will always be the need to fill in gaps, by way of implication into the express words or based on the conduct of the copyright owner, or to give effect to a custom or a policy. Regardless of the extent of codification of the terms implied, there will still be circumstances where courts will be called upon to imply a copyright licence.

The current environment within which copyright law must operate is characterised by constantly changing technologies. This thesis demonstrated that the flexible yet targeted approach of the doctrine of implied licence is a sound response to such dynamism. With the frameworks proposed in this thesis, it should no longer be open for the courts and practitioners to hide behind the uncertainty of implying a copyright licence. Instead, implied licences should be deployed to their fullest potential, to achieve a just and fair result to copyright infringement matters in both online and offline scenarios. 
Chart II

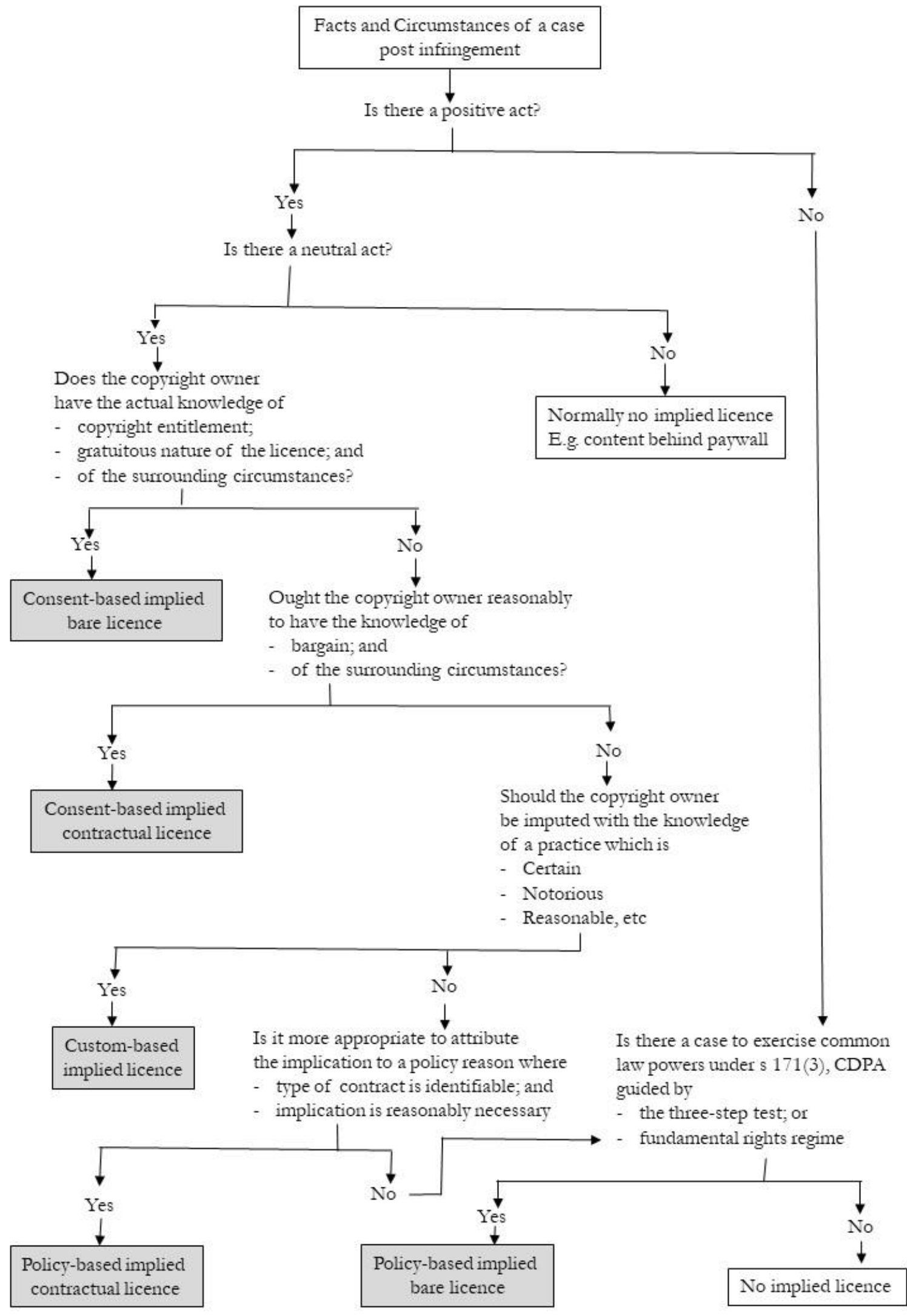




\section{Bibliography}

- - ALAI 15 September 2013, Report on the making available and communication to the public in the internet environment - focus on linking techniques on the internet, http://www.alai.org/en/assets/files/resolutions/making-available-right-report-opinion.pdf

- - European Copyright Society: The Reference to the CJEU in Case C-466/12 Svensson, Paper No 6/2013, February 2013, para 6, http://ssrn.com/abstract=2220326

- - Halsbury's Laws of England, Vol 32, para 51

— - HL Deb 08 December 1987, vol 491

— - HL Deb 23 February 1988, vol 493

— - HL Deb 29 March 1988, vol 495

— - https://support.google.com/legal/troubleshooter/1114905?hl=en

_ — https://support.google. com/webmasters/answer/79812?hl=en

— - https://support.google.com/webmasters/answer/6062608?hl=en

— — https://support.google.com/webmasters/answer/79812?hl=en

— - http://www.bbc.co.uk/news/politics/eu_referendum/results

— - http://www.bbc.co.uk/news/uk-politics-38641208

— - http://www.gucci.com/uk/assistance/copyright_information

— - https://www.facebook.com/legal/terms

— - https://www.ft.com/content/22c0d426-1466-11e7-b0c1-37e417ee6c76

— - http://www. londonstockexchange.com/global/legal/disclaimer.htm

— - http://www.nlamediaaccess.com/uploads/public/WDL\%20April\%202016\%20Tariff

.pdf

— - https://www.ryanair.com/en/terms-of-use/

— - http://www.telegraph.co.uk/topics/about-us/3692012/Terms-and-Conditions.html

— — http://www.telegraph.co.uk/topics/about-us/3692012/Terms-and-Conditions.html

_ — WIPO Glossary of the Terms of Law of Copyright and Neighbouring Rights, 1983

Afori O F, Implied Licence: An Emerging New Standard in Copyright Law, [2009] 25 Santa Clara Computer \& High Tech LJ 275

Arnold R, 'Reflections on "The Triumph of Music": copyrights and performers' rights in Music’ [2010] IPQ 153

- - and Rosati E, 'Are national courts the addressees of the InfoSoc three-step test?' [2015] 10 JIPLP 741 
Atiyah P S and Smith, S, Atiyah's Introduction to the Law of Contract $\left(6^{\text {th }}\right.$ edn, Clarendon Press 2005)

Aufderheide P and Jaszi P, Reclaiming Fair Use: how to put balance back in copyright (University of Chicago Press, 2011)

Austen-Baker R, Implied Terms in English Contract Law (Edward Elgar 2011)

Baines R, 'Copyright in commissioned works: a cause for uncertainty', [2005] EIPR 122

Balen $\mathrm{M}$ and Knowles C, 'Failure to estop: rationalising proprietary estoppel using failure of basis’ [2011] Conv 176

Beatson J, Burrows, A and Cartwright, J, Anson's Law of Contract (30 ${ }^{\text {th }}$ edn, OUP 2016)

Bently L and Sherman B, Intellectual Property Law (4th edn, OUP 2014)

Birks P, 'Before we begin: Five keys to Land Law' in Bright, S \& Dewar, J (eds), Land Law Themes and Perspectives (OUP 1998)

Bradley A W, et al, Constitutional \& Administrative Law (16 ${ }^{\text {th }}$ edn, Pearson 2015)

Breaky H, 'Properties of copyright' in Howe, H and Griffiths, J (eds), Concepts of Property in Intellectual Property Law (CUP 2013)

Bridge M, Personal Property Law (OUP, 2015)

- - The Sale of Goods (3 ${ }^{\text {rd }}$ edn, OUP 2014)

Bunnin $\mathrm{N}$ and $\mathrm{Yu}$ J (eds), The Blackwell Dictionary of Western Philosophy (Blackwell Publishing 2004)

Burrell R, 'Defending the public interest' [2000] EIPR 394

— - and Coleman A, Copyright Exceptions The Digital Impact (CUP 2005)

Christoffersen J, 'Human Rights and balancing: The principle of proportionality' in Geiger, C (ed), Research Handbook on Human Rights and Intellectual Property (Edward Elgar, 2015)

Clark B, 'Google Image Search does not infringe copyright, says Bundesgerichtshof [2010] 5 JIPLP 553

— - 'Google image search still does not infringe copyright, reaffirms Bundesgerichtshof [2012]7 JIPLP 788

Clark C, 'Licences in Real Property Law’ [1921] 21 Colum L Rev 757

Collins H, The Law of Contract (4th edn, LexisNexis 2003)

Cornish W, Llewelyn D and Aplin T, Intellectual Property (8th edn, Sweet \& Maxwell 2013)

Davies G, Caddick N, and Harbottle, G, Copinger and Skone James on Copyright (17th edn, Sweet \& Maxwell 2016)

Dinwoodie G, 'The Development and Incorporation of International Norms in the formation of Copyright Law' [2001] 62 Ohio St LJ 733

Dixon M, Modern Land Law (10 th edn, Routledge 2016) 
Douglas S, 'Kuwait Airways Corporation v Iraqi Airways Company' in Douglas, S, Hickey, R and Waring, E (eds) Landmark Cases in Property Law (Hart Publishing, 2013)

Epstein R, 'International News Service v Associated Press: Custom and Law as Sources of Property Rights in News’ [1992] 78 Va L Rev 85

_ — 'Some Reflections on Custom in the IP Universe' [2007] 93 Va L Rev Brief 223

Gardner S and McKenzie E, An Introduction to Land Law (4 ${ }^{\text {th }}$ edn, Hart Publishing, 2015)

Garnett K, Davies G, and Harbottle G, Copinger and Skone James on Copyright (16th edn, Sweet \& Maxwell, 2011)

Geiger C, 'From Berne to National Law, via the Copyright Directive: The Dangerous Mutations of the 'Three-Step Test' [2007] EIPR 486

_ - Intellectual Property Shall be Protected!? Article 17(2) of the Charter of Fundamental Rights of the European Union' [2009] EIPR 113

- - Gervais D and Senftleben M, 'The Three-Step Test Revisited: How to Use the Test's Flexibility in National Copyright Law' (2013) PIJIP Research Paper no. 2013-04

Ginsburg J, 'Creation and Commercial Value: Copyright Protection of Works of Information' 90 Colum L Rev 1865

Goymour A, 'Property and housing' in Hoffman, D (ed), The Impact of the UK Human Rights Act on Private Law (CUP 2013)

Gray K and Gray S F, Elements of Land Law (5 ${ }^{\text {th }}$ edn, OUP 2009)

Griffiths J, 'Copyright law after Ashdown - time to deal fairly with the public' [2002] IPQ 240

_ _ 'The "Three-step Test" in European Copyright Law - Problems and Solutions', [2009] IPQ 428

_ _ 'The balancing methodology' (CIPIL Annual Spring Conference, Cambridge, March 2017)

- _ 'Unsticking the centre-piece - the liberation of European copyright law?' 1 (2010) JIPITEC 87

Harno A J, 'The Revocability of Licences as Applied to Property in Land' [1919] 7 Ky LJ 1

Harpum C, Bridge S and Dixon M, Megarry and Wade The Law of Real Property ( $8^{\text {th }}$ edn, Sweet \& Maxwell 2012)

Harris J W, Property and Justice (OUP 2002)

Hart M, 'The legality of internet browsing in the digital age' [2014] EIPR 630

He H, 'Seeking a balanced interpretation of the three-step test' [2009] IIC 274

Helfer L, 'How Intellectual Property and Human Rights Can Live Together' in Torremas, P (ed), Intellectual Property Law and Human Rights ( $3^{\text {rd }}$ edn, Wolters Kluwer 2015)

Hill J, ‘Termination of bare licences’ [2001] CLJ 89 
Hoffmann L, 'Anthropocentric Justice: The Reasonable Man and his Friends', (1995) 29 Law Teacher 127

Hohfeld W N, 'Some Fundamental Legal Conceptions as applied in Judicial Reasoning' [191314] 23 Yale LJ 16

_ _ 'Fundamental Legal Conceptions as applied in Judicial Reasoning' [1916-17] 26 Yale LJ 710

__ 'Faulty Analysis in Easement and Licence Cases' [1917] 27 Yale L J 66

Honoré A M, 'Ownership' in Guest, A G (ed), Oxford Essays in Jurisprudence (Clarendon Press 1961)

Jasiewicz M I, 'Copyright Protection in an Opt-Out World: Implied License Doctrine and News Aggregators’ [2012] 122 Yale LJ 837

Jones L A K, 'Is Viewing a Web Page Copyright Infringement?' (1998) 4 Appeal 60

Katz A, 'Digital exhaustion: North American observations', in Rothchild, J A (ed), Research Handbook on Electronic Commerce Law (Edward Elgar, 2016)

Koelman K, 'Fixing the three step test' [2006] 28 EIPR 407

Lee S, 'Towards a Jurisprudence of Consent' in Eekelaar, J and Bell, J (eds), Oxford Essays in Jurisprudence Third Series (Clarendon Press, 1987)

Leistner M, 'The German Federal Supreme Court's Judgment on Google's Image Search' [2011] 42 IIC 417

Llewellyn G, 'Does Copyright Recognise a Right to Repair?' [1999] EIPR 596

McFarlane B, The Structure of Property Law (Hart Publishing 2008)

- - The Law of Proprietary Estoppel (OUP 2014)

- - Hopkins N and Nield S, Land Law Text, Cases and Materials (3 ${ }^{\text {rd }}$ edn, OUP 2015)

McMeel G, The Construction of Contracts: Interpretation, Implication, and Rectification ( $2^{\text {nd }}$ edn, OUP 2011)

Merrill T, 'Property and the Right to Exclude' (1998) 77 Neb L Rev 730

Mulligan C, 'A Numerus Clausus Principle for Intellectual Property' [2013] 80 Tennessee L Rev 235

Newman C, "A License is not a "Contract not to Sue": Disentangling Property and Contract in the Law of Copyright Licenses [2013] 98 Iowa Law Review 1101

- _ "What Exactly are you Implying?": the Elusive Nature of the Implied Copyright Licence' [2013-14] 32 Cardozo Arts \& Ent LJ 501

Palmer N, Palmer on Bailment (3rd edn, Sweet \& Maxwell 2009)

Peden E, 'Policy concerns behind implication of terms in law' [2000] LQR 459

Peel E and Goudkamp J, Winfield and Jolowicz, on Tort (19th edn, Sweet \& Maxwell 2014) 
Perzanowski A, and Schultz, J, 'Digital Exhaustion’, [2011] 58 UCLA L Rev 889

Phang A, 'Implied terms revisited', [1990] JBL 394

_ _ 'Implied terms in English law - some recent developments' [1993] JBL 242

Phillips J and Bently L, ‘Copyright issues: the mysteries of section 18’ [1999] EIPR 133

Pihlajarinne T, 'Setting the Limits for the Implied License in Copyright and Linking Discourse

- The European Perspective' [2012] 43(6) IIC 700

Polański P, Customary law of the internet: in the search for a supranational cyberspace law (University of Melbourne, 2007)

Rahmatian A, Copyright and Creativity (Edward Elgar 2011)

Reichmant J, Dinwoodie G and Samuelson P, 'A reverse notice and takedown regime to enable public interest uses of technologically protected copyrighted works' [2007] 22 Berkeley Tech LJ 981

Ricketson S, 'The three-step test, deemed quantities, libraries and closed exceptions' (Centre for Copyright Studies 2002)

- - and Ginsburg J, International Copyright and Neighbouring Rights ( $2^{\text {nd }}$ edn, Vol 1, OUP 2005)

- - and Ginsburg J, International Copyright and Neighbouring Rights ( ${ }^{\text {nd }}$ edn, Vol 2, OUP 2005)

Rosati E, 'Copyright in the EU: in search of (in)flexibilities' [2014] 9 JIPLP 585

Rothman J E, 'The Questionable Use of Custom in Intellectual Property' [2007] 93 Va L Rev 1899

_ _ 'Why Custom Cannot Save Copyright's Fair Use Defense', (2008) 93 Va L Rev In Brief 243

- _ 'Copyright, Custom and Lessons from the Common Law' in Balganesh, S (ed), Intellectual Property and Common Law (CUP 2013)

Ruse-Khan H G, 'Overlaps and conflict norms in human rights law' in Geiger, C (ed) Research Handbook on Human Rights and Intellectual Property (Edward Elgar, 2015)

Samuelson P, 'Challenges for the WIPO and the TRIPS Council in Regulating Intellectual Property Rights in the Information Age' [1999] EIPR 578

Seiman J, 'Using the Implied Licence to Inject Common Sense into Digital Copyright', 2007 85 NCL Rev 885

Senftleben M, Copyright, Limitations and the Three-Step Test (Kluwer Law 2004)

- _ 'The International Three-Step Test A Model Provision for EC Fair Use Legislation' (2010) 1 JIPITEC 67

Sims A, 'The public interest defence in copyright law: myth or reality?' [2006] EIPR 335

Smith G, et al, Internet Law and Regulation (Sweet \& Maxwell 2007)

Smith H, 'Property as the Law of Things' (2012) 125 Harv L Rev 1691 
Smith R, Property Law (8 ${ }^{\text {th }}$ edn, Pearson 2014)

Steyn J, 'Written Contracts: To What Extent May Evidence Control Language?’ [1988] CLP 23

_ _ 'Contract law: fulfilling the reasonable expectations of honest men' [1997] 113 LQR 433

Vermut R S, 'File Caching on the Internet: Technological Infringement or Safeguard for Efficient Network Operation?' [1997] 4 J Intell Prop L 273

Vitoria M, et al, Laddie, Prescott and Vitoria's Modern Law of Copyright (4th edn, LexisNexis, 2011)

Voorhoof D, 'Freedom of expression and the right to information: Implications for copyright' in Geiger C (ed), Research Handbook on Human Rights and Intellectual Property (Edward Elgar 2015)

Westkamp G, The 'Three-step Test' and Copyright Limitations in Europe' (2008-2009) 56 J Copyright Soc'y USA 1

Young A, 'Horizontality and the EU Charter' (UK Constitutional Law Association, 29 January 2014) https://ukconstitutionallaw.org/2014/01/29/alison-young-horizontality-and-the-eucharter/

- - 'Mapping horizontal effect' in Hoffman, D (ed), The Impact of the UK Human Rights Act on Private Law (CUP 2013) 